\title{
BIBLIOGRAPHY OF IOWA GEOLOGY BY
}

\author{
CHARLES ROLLIN. KEYES.
}

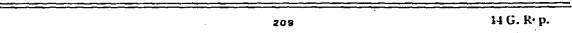





\section{BIBLIOGRAPHY OF IOWA GEOLOGY.}

BY. CIIARLES ROLLIN KEYES.

Before pntering upon any investigation a knowledge of what has already been done in the same line is very essential, in order that labor may not be uselessly expended in duplicating work.

In glancing over the titles herein enumerated, the majority of the people in the State will probably be impressed at once with the large number of references, and with the apparently extensive literature pertaining to the geology of Iowa. More careful perusal, however, will doubtless bring out the striking fact that with few exceptions the publications are purely scientific in character. The reason for this is notfar to seek. For a long period of years past scientific work in the State has received little or no public aid or encouragement. Whatever work has been carried on has been done at private expense by scientific men who have received no financial compensation in return for either their time or the money necessary to prosecute their researches. Thus, only the purely scientific results were placed before the world; while all the economic aspects of the various lines of investigation were unable to be directed through those channèls most likely to reach the people of the State. This information has therefore been largely forgotten or put away in places now almost entirely inaccessible to the public. Nevertheless, the scientific work 
so generously done by persons having no hope of reward or public aid has placed the economical investigation of Iowa's natural resources on a firmer basis than could possibly have been done otherwise, without years of special labor.

The arrangement of the present index to the literature pertaining to the geology of Iowa was intended, primarily, for the convenience of members of the Survey. Portions of it, as a card catalogue of authors, was originally started some years ago. A large number of additions have been made recently, and the whole is brought together. now in the form of a bibliography of the subject.

The plan is essentially that of a dictionary catalogue or bibliographical index. It consists of :

(1) An author's list, in which is given the full title, volume, pages, and illustrations of the book or serial in which each article appeared, place and date of publication. This is followed by a very brief synopsis of the contents of each paper.

(2). A title index, in which the name of each article appears under each of its leading words. Then comes the name of the author and an abbreviated reference to its place of appearance.

(3) Subject entries and cross-references. These embrace, under each topic, all references to any particular subject, as to each county, geological formation, zoological group, special subject, etc. ; also those writings referring to Iowa in general. The names of authors, and abbreviated references to place and time of publication are given in all cases. Whenever additional information is wanted, reference can be made to the name of the author.

For convenience the whole is arranged alphabetically. 
It is believed that the list of papers is fairly complete; though doubtless there are some omissions.

One of the most noticeable considerations connected with the bibliographical index is the fact that the literature is so widely scattered, and now largely inaccesible to the people of the State. The last of the two earlier geological reports was issued nearly a quarter of a century ago. They were rather sparingly distributed, and during the period which has elapsed. since their publication most of the copies have been lost, destroyed, or passed beyond the boundaries of the State. In the meantime the population has largely increased, so that if the reports were all at hand the supply would be inadequate. A goodly number of references have appeared in the publications of leading. societies and have had a limited distribution, a large share of which has been foreign. Many of the papers referring to the geological phenomena as presented in Iowa are found in the reports of other states; still others are scattered far and wide through various journals and serials, both in English and foreign languages; besides, there are many short articles, and more or less lengthy allusions included in the long list of publications printed by the Federal government. A large majority of these descriptions are unknown to the people of the State, who, consequently, know not where to look for the information desired.

Yet all these have to be gone over, involving so much time and labor that considerable hesitancy arises before the preparation of indices of this kind are entered upon finally.

Bibliography.

Abstract of an Introduction to the Final Report on the Geological Survey made in Wisconsin, Iowa and Min- 
nesota in the years 1847-1850, containing a Synopsis of the Geological Features of the Country. D. D. Owen. (Proc. Am. Assoc. Ad. Sci., Vol. V, Cincinnati Meeting, 119-131. 1851.)

Adair County.

Analyses of Peat. Rush Emery. (Geol. Iowa, II, 401. 1870.)

Geology. C. A. White. (Geol. Iowa, I, 336-339. 1870.) The drainage and surface characters briefly described. A few notes with section of the rocks given, with reference to the probable material resources, and notice of peat beds.

Notes on the Surface Features. C. A. White. (First Ann. Rep. State Geologist, 68-69. 1868.)

Adams County.

Analyses of Coal. Rush Emery. (Geol. Iowa, II, 389. 1870.)

Brief Notes on the Surface Features. C. A. White. (First Ann. Rep. State Geologist, 66-68. 1868.)

General Remarks. C. A. White. (Geol. Iowa, I, 339343. 1870.) Drainage and surface characters alluded to. The geological features along the Nodaway river briefly described. Allusion also made to the rich soil of the county.

Additional Notes on the Devonian Rocks of Buchanan County,Iowa. S. Calvin. (Am. Geologist, VIII, 142145. 1891.)

Additional Observations on Iowa Kames and Aasar. W.

J. McGee. (Proc. Iowa Acad. Sci., 25. 1880.).

Age of Certain Sandstones near Iowa City. C. R. Keyes. (Proc. Iowa Acad. Sci., 25. 1892.)

Age of the Goniatite Limestone at Rockford, Indiana, and its Relations to the Black Slate of the Western 
Age, etc.-Continued.

States and to some of the succeeding rocks above the latter. F. B. Meek and A. H. Worthen. (Am. Jour. Sci., (2), XXXII, 167-177. 1861.)

Allamakee County.

Notice of the Geology. J. D. Whitney. (Geol. Iowa, I, 317-323. 1858.)

\section{Alluvium.}

General Remarks. C. A. White. (Geol. Iowa, I, 102103. 1870.) Brief account of the alluvial deposits of the State.

In Henry county. A. H. Worthen. (Geol. Iowa, I, 210. 1858.)

Of Northeastern Iowa. W. J. McGee. (Eleventh Ann. Rep. U. S. Geol. Sur., 417-425. 1892.)

Altitudes in Iowa. Henry Gannett. (Bul. U. S. Geol. - Sur., No. 5, Iowa, 105-112. 1884.)

Aluminum.

Aluminum in Iowa. C. R. Keyes. (Proc. Iowa Acad. Sci., 1890-1891, 29-30: 1892.) Announcement of the establishment of a plant for the manufacture of aluminum in Franklin county.

American Species of Polyphemopsis. C. R. Keyes. (Proc. Acad. Nat. Sci., Phila., 299-302. 1889.)

Annotated Catalogue of the Mollusea of Iowa. C. R. Keyes. (Bul. Essex Inst., XX. 1889.)

Announcement of the Existence of Cretaceous Rocks in Guthrie County, Iowa. C. A. White. (Proc. Amer. As. Adv. Sci., XVII, 326-327. 1869.)

Annual Deposits of the Missouri River During the PostPliocene. J. E. Todd. (Proc. Am. As. Ad. Sci., XXVI, 287-291. 1877.)

Annual Report (First) of Progress of the State Geologist. C. A. White. (pp. 1-4. Des Moines, 1867.) 
Anon. Mineral Resources of the United States for the year 1885. (U. S. Geol. Sur., Statistical Papers, 516. Washington, 1886.)

Appanoose County.

General Description of Geology. C. A. White. '(Geol. Iowa, II, 270. 1870.) Merely a brief reference to the geology of the county.

Reference to the Rock Exposures. C. A. White. (First Ann. Rep. State Geologist, 40. 1868.)

Artesian Wells.

Artesian Wells in Iowa. R. E. Call. (Proc. Iowa Acad. Sci., 1890-1891, 57-63.) An abstract of notes on the artesian wells in Iowa; with-sketch-map.

At Davenport. A. S. Tiffany. (Am. Geologist, III, 117-118. 1889.)

At Keokuk, Ottumwa and Sigourney. C. H. Gordon. (Am. Geologist, IV, 237-239. 1889.)

Chemical Analyses of Waters. R. E. Call. (Monthly Rev. Iowa Weather and Crop Service, II, No. 2, 1-5. 1892.)

General Description. C. A. White. (Geol. Iowa, II, 331-333. 1880:) A brief general account of the artesian wells in different parts of the State.

In Iowa. R. E. Call. (Monthly Rev. Iowa Weather and Crop Service, III, No. 3, 1-15. 1892.)

Preliminary Paper on Artesian Wells in Iowa. R. E. Call. (Monthly Rev. Iowa Weather and Crop Service, II, 1-6. 1891.)

\section{Asteroids.}

New Species from the Burlington. F. B. Meek and A. H. Worthen. (Proc. Acad. Nat. Sci., Phila., XIX, 251-275. 1868.) 
Attachment of Platyceras to Fossil Grinoids. C. R. Keyes. (Aim. Naturalist, XXII, 924. 1888.)

Audubon County.

General features briefly described. O. H. St. John.

(Geol. Iowa, II, 164-167. 1870.)

Barbour, E. H., Joseph Torrey and. The Recorded Meteorites of Iowa, with Special Mention of the Last or Winnebago County Meteorite. (Am. Geologist, vol. VIII, pp. 65-72. Minneapolis, 1891.) See Joseph Torrey and E. H. Barbour, 1891.

Barbour, Edwin H., Joseph Torrey, Jr. and. The :Winnebago County (Iowa) Meteorites. (Science, vol. XV, p. 347. 1890.) See Joseph Torrey and E. H. Barbour, 1890.

Barris, W. H. Description of Some New Blastoids from the Hamilton Group. (Geol. Sur. Illinois, vol. VII, pp. 357-364. Springfield, 1883.) The following species from Iowa described as new :

Elxacrinus obovatus.

Eliacrinus meloniformis.

Barris, W.H. . Descriptions of New Crinoids and Blastoids from the Hamilton Group. (Proc. Davenport Acad. Sci., vol. IV, pp. 88-94. 1885.) Revised descriptions of the new species Elxacrinus obovatus and E. meloniformis.

Barris, W. H. New Fossils from the Corniferous Form-ation at Davenport. (Proc. Davenport Acad. Nat. Sci., vol. II, pp. 282-288. Davenport, 1878.) The following genera and species described as new :

Stereocrinus.

Stereocrinus triangulatus.

Stereocrinus triangulatus var. livatus.

IIegistocrinus nodosus.

15 G. Rep. 
Barris, $\$$ W. H.-Continued.

Rhynchonella intermedia.

Avicula (Plerinea) cancellata.

Gyroceras pratti.

Pratus davenportensis:

Barris, W. H. Notes on Our Local Geology, No. II. (Proc. Davenport Acad. Nat. Sci., vol. III, pp. 163-168. 1882.)

Barris, W. H. Stereocrinus, Barris. (Proc. Davenport Acad. Nat. Sci., vol. IV, pp. 102-104. 1885.) Description of this new genus from the Devonian of Iowa.

Barris, W. H. The Local Geology of Davenport and Vicinity. (Proc. Davenport Acad.- Nat. Sci., vol. II, pp. 261-269. Davenport, 1877.) A general sketch of the geology of the region, with special reference to the fossils contained in the rocks.

Barytes.

From Decatur, Madison; Marion; Johnson, Bremer and Dubuque counties. C. A. White. (Geol. Iowa, II, 305. 1870.)

Beachler, Charles S. Keokuk Group of the Mississippi Valley. (Am. Geologist, vol. X, pp. 88-96. Minneapolis, 1892.) A short sketch of the Keokuk rocks, with an attempt to a correlation of the different beds in the several states of the upper Mississippi region.

Beds of Carboniferous Drift in the Bluffs of East Davenport. Tylor McWorther. (Proc. Davenport Acad. Nat. Sci., III, 129-130. Davenport, 1882.

Benton County.

Geological notes. J. D. Whitney. (Geol. Iowa; I, 260-266. 1858.)

Biennial Report of the State Mine Inspector to the Governor of the State of Iowa, for the years 1880-1881. P. C. Wilson. (165 pp. Des Moines, 1882.) 
Bierbauer, Bruno. A Check List of the Paleozoic Fossils of Wisconsin, Minnesota, Iowa, Dakota and Nebraska. (Bul. Minnesota Acad. Nat. Sci., vol. III, pp. 206-247. Minneapolis, 1888.) Many of the species described from Iowa listed.

Binks, Thomas. Report of the Mine Inspector of the First District. (Third Biennial Report of the State Mine Inspectors, for the years 1886-1887, pp. 1-80. Des Mốines, 1888.) A list of the mines and the improvements, with short accounts of the different mines operated in southeastern Iowa.

Binks, Thomas. Report of the Mine Inspector for the First District. (Fourth Biennial Report of the State Mine Inspectors, 1888-1889, pp. 1-65. Des Moines, 1889.) A list of the mines, their output, with short accounts of the different openings.

Binks, Thomas. Report of the Mine Inspector for the First District. (Fifth Biennial Report of the State Mine Inspectors for the years 1890-1891, pp. 1-51. Des Moines, 1891.) Short accounts of the different mines in southeastern Iowa, with tables showing the number of mines, output, number of miners, and value of products.

Black Hawk County.

Cretaceous Fossils in the Drift. G. A. White. (Proc. Am. As. Adv. Sci., XXI, 187-192. 1873.)

Hydraulic cement. C. A. White. (First Ann. Rep. State Geologist, 20-21. 1868.)

Species of the new genus Newberria from the Devonian noted. J. Hall. (Tenth Ann. Rep. State Geol-

\section{Blastoids.}

$$
\text { ogist of New York, 91-102. 1891.) }
$$

Description of New Crinoids and Blastoids from the Hamilton Group. W. H. Barris. (Proc. Dav- 
Blastoids.-Continued.

enport Acad. Nat. Sci., IV, 88-94. 1885.) Description of the new species Elaacrinus obovatus and $E$. meloniformis.

Description of New Species from the Hamilton Group. W. H. Barris. (Geol. Sur. Illinois, VII, 357-365. 1883.)

Description of New Species from Iowa Rocks. F. B. Meek and A. H. Worthen. (Geol. Sur. Mlinois, II, 143-411. 1866.)

Description of New Species from the Lower Carboniferous of Iowa. F. B. Meek and A. H. Worthen. (Geol. Sur. Illinois, V, 323-619. 1873.)

New Species from Burlington, F. B. Meek and A. H. Worthen. (Proc. Acad. Nat. Sci., Phila., XXI, 8391. 1869.)

New Species from the Burlington Limestone at Burlington. F. B. Meek and A. H.:Worthen. (Proc.

- Acad. Nat. Sci., Phila., XIII, 22-56. 1870.)

New Species from the Burlington Limestone of Iowa. F. B. Meek and A. H. Worthen. (Proc. Acad. Nat. Sci., Phila., XIII, 128-148. 1861.)

New Species from the Kinderhook of Marshall County. C. Wachsmuth and F. Springer. (Geol. Sur. Illinois, VIII, 157-251. 1890.)

New Species of Blastoidea from the Paleozoic Rocks of the Western States. B. F. Shumard. (Trans. Acad. Sci., St. Louis, I, 238-248. 1858.)

Bones of the Mammoth in Washington County, Iowa. J. Gass and W. H. Pratt. (Proc. Davenport Acad. Nat. Sci., III, 177-178. 1882.)

Boone County.

Analyses of coal. Rush Emery. (Geol. Iowa, II, 390-391.. 1870.) 


\section{Boone County.-Continued.}

Coal mines at Boonsboro. C. A. White. (Second Ann. Rep. State Geologist, 142. 1868.)

General Description. C. A. White. (Geol. Iowa, II, 259. 1870.) Mere reference to the geology of the county.

\section{Brachiopods.}

Brachiopoda. James Hall. (Nat. Hist. New York, Pal., VII, Part i, 1-367. 1892.)

Contribution to the Fauna of the Lower Coal Measures of Central Iowa. C. R. Keyes. (Proc. Iowa Aead. Sci., 1890-1891, 22-23. 1892.) A preliminary note. One species described from the Lower Coal Measures at Des Moines.

Description of New Genera and Species. C. A White and O. H. St. John. (Pamphlet, pp. 1-3. Iowa City, 1867.)

Description of New Species. F. B. Meek and A. H:

Worthen. (Geol. Sur. Illinois, III, 289-565. 1868.)

Description of New Species. D. D. Owen. (Rep. Geol. Sur. Wis., Iowa and Minn., App. Art. i, 583586. 1852.)

Description of New Species from Iowa. C. A. White. (Proc. Bost. Soc. Nat. Hist., IX, 8-33. 1865.)

Description of New Species from Iowa Rocks. F. B. Meek and A. H. Worthen. (Geol. Sur. Illinois, II, 143-411. 1866.)

Description of New Species from the Iowa Lower Carboniferous. F. B. Meek and A. H.Worthen. (Geol. Sur. Illinois, III, 289-565. 1868.)

Description of a New Species of Spirifera from the Hamilton Group, near Iowa City, Iowa. S. Calvin. (Bul. Lab. Nat. Hist. State Univ. Iowa, I, 28-29. 1889.) 
Brachiopods.-Continued.

Fauna of Lime Creek. S. Calvin. (Am. Jour. Sci., (3), XXV, 434-436. 1883.)

Five new species from the dark shale at Independence. S. Calvin. (Bul. U. S. Geol. and Geog. Sur., IV, 725-730. 1878.)

From eastern Nebraska. F. B. Meek. (Final Report U. S. Geol. Sur. Neb., pt. ii, 83-245. 1872.)

From various parts of Iowa. J. N. Nicollet. (Sen. Doc., 26 Cong., 2nd Sess., V, pt. ii, No. 237. 1841.)

- Lower Carboniferous and Coal Measure' species. C.

A. White and O. H. St. John. (Trans. Chicago Acad. Sci., I, 115-127. 1867.)

New genera and species from "yellow" sandstones at Burlington. A. Winchell. (Proc. Acad. Nat. Sci., Phila., 225. 1863.)

New species from Burlington. G. A. White. (Boston Jour. Nat. Hist., VII, 209-235. 1860.)

New species from Burlington. C. A. White and R. P. Whitfield. (Proc. Boston Soc. Nat. Hist.,VIII, 289316. 1862.)

New species from Burlington. A. Winchell. (Proc. Acad. Nat. Sci., Phila., XVII, 109-133. 1865.)

New species from the Devonian. J. Hall and R. P. Whitfield. (New York State Cab. Nat. Hist., 23rd Ann. Rep., 223-239. 1873.)

New species from the Devonian, at Davenport. W. $\mathrm{H}$. Barris. (Proc. Davenport Acad. Nat. Sci., II, 282288. 1878.)

New species from Iowa. C. A. White. (Rep. Geog. and Geol. Expl. and Surv. W. 100 Merid., IV, 1-219. 1875.)

New species from Iowa. C. A. White. (Twelfth Ann. 
Brachiopods.-Continued.

Rep. U. S. Geol. and Geog. Surv. Torr., 155-171. 1883.)

New species from the Lower Carboniferous rocks of Iowa. A. H. Worthen and F. B. Meek. (Geol. Sur. Illinois, VI, 489-532. 1875.)

New species of Paleozoic fossils. S. Calvin. (Bul. Lab. Nat. Hist. State Univ. Iowa, I, 173-181. 1890.) New species from Paleozoic rocks of Iowa. C. A. White. (Proc. Acad. Nat. Sci., Phila., XXVIII, 27-34. 1877.)

Notes on the Synonymy, Characters and Distribution of Spirifera parryana, Hall. S. Calvin. (Bul. Lab. Nat. Hist. State Univ. Iowa, I, 19-28. 1888.) Of central Iowa. C. R. Keyes. (Proc. Acad. Nat. Sci., Phila., 231-247. 1888.)

Paleontology of New York. J. Hall. (Nat. Hist. New่ York, Paleontology, IV, 422. 1867.) A number of references to fossils occurring in Iowa.

Preliminary Notice of Newberria, a New Genus of Brachiopods. J. Hall. (Tenth Ann. Rep. State Geologist of New York, 91-102: 1891.) Species from Iowa noted.

Producti Found in the Western States and Territories, with Description of Twelve New Species. J. G. Norwood and H. Pratten. (Jour. Acad. Nat. Sci., Phila., (2), III, 5-22. 1855.)

Species mentioned from Iowa. R. P. Whitfield. (Bul. Mus. Nat. Hist., I, 39-97. 1882.)

Synonymy of Two Species of Spirifera. S. A. Miller. (Proc. Davenport Acad. Nat. Sci., II, 220-221. 1878.)

Two new species from the Devonian. C. R. Keyes. (Proc. Acad. Nat. Sci., Phila., 247-248. 1888.) 
Brecciated Character of the St. Louis Limestone. C. H. Gordon. (Am. Naturalist, vol. XXIV, pp. 305-313. 1890.)

\section{Bremer County.}

Hydraulic cement. C. A. White. (First. Ann. Rep. Brick. State Geologist, 20-21. 1868.)

Brick and Other Clays of Des Moines. C. R. Keyes. (Proc. Iowa Acad. Sci., 1890-1891, 29. 1892.) A brief statement of the clay industries at Des Moines.

Bryozoans.

New species. E. O. Ulrich. (Geol. Surv. Illinois, VIII, 283-688. 1890.)

Observations on the Genus Archimedes. J. Hall: (Proc. Am. As. Ad. Sci., 170-180. 1857.)

\section{Buchanan County.}

Dark shales and fossils at Independence, Iowa. S. Calvin. (Bul. U. S. Geol. and Geog. Sur., IV, 725730. 1878.)

Devonian Rocks. S. Calvin. (Am. Geologist, VIII, 142-145. 1891:)

New Genus of Gorals from the Devonian. C. L. Webster. (Am. Nat., XXIII, 710-712. 1889.)

New species of Paleozoic fossils. S. Calvin. (Bul. Lab. Nat. Hist. State Univ. Iowa, I, 178-179. 1890.) Notes on the geology. J. D. Whitney. (Geol: Iowa, I, 295-296. 1858.)

\section{Buena Vista County.}

General description. - C. A. White. (Geol. Iowa, II, 223-226. 1870.) Mere reference to the surface features. 


\section{Building Stones.}

Description of the Quarries and Quarry Regions of Iowa. W. J. McGee. (Tenth Census U. S., X, Rep. Building Stones, 256-265. 1883.)

General references to the building stones of Iowa. G. P. Merrill. (Stones for Building and Decorating, 453 pp. New York, 1891.)

General references to the building stones of Iowa. G. P. Merrill. (Smithsonian Inst., Rep. 1885-1886, part ii, 277-648. 1889.)

In Iowa. W. C. Day. (Report of the Mining Industry of the U. S. at 11th Census, 1890, 593-666. 1892.)

In Lee county. A. H. Worthen. (Geol. Iowa, I, 196197. 1858.)

\section{Burlington Limestone.}

Attachment of Platyceras to Palreocrinoids. C. R. Keyes. (Proc. Am. Philos. Soc., XXV, 231-248, 1888.) Descriptions of examples and four new species of gasteropods.

Brachiopods from various localities in Iowa. J. Hall. (Nat. Hist. New York, Pal., VIII, 1-367. 1892.)

- Certain Forms of Straparollus from Southeastern Iowa.

C. R. Keyes. (Am. Geologist, V, 193-197. 1890.) Classification of the Lower Carboniferous Rocks of the Mississippi Valley. C. R. Keyes. (Washington; Judd \& Detweiller, printers, 1-24. 1892.) Sec- · tions and details of the rocks in southeastern Iowa.

Description of fossils. James Hall. (Geol. Iowa, I, 524-605. 1858.)

Description of fossil fishes. O. H. St. John and A. H. Worthen. (Geol. Sur. Illinois, VII, 53-264. 1883.) 
Burlington Limestone.-Continued.

Description of new species of crinoid. R. P. Whitfield. (Bul. Am. Mus. Nat. Hist., I, 7-9. 1881.)

Description of new species of Crinoidea. J. Hall. (Bost. Jour. Soc. Nat. Hist., VII, 251-328.' 1861.)

Description of New Species of Crinoids. D. D. Owèn and B. F. Shumard. (Rept. Geol. Sur. Wis., Iowa and Minn., App., Art. ii, 587-598. 1852.)

Description of new species of crinoids from Burlington. F. B. Meek and A. H. Worthen. (Proc. Acad. Nat. Sci., Phila., XXI, 67-83. 1869.)

Description of new species of fishes. O. H. St. John and A. H. Worthen. (Geol. Sur. Illinois, VI, 245288. 1875.)

Description of new species of echinoderms. F. B. Meek and A. H. Worthen. (Proc. Acad. Nat. Sci., Phila., XIX, 251-275. 1868.)

Description of new species of fossils. F. B. Meek and A. H. Worthen. (Geol. Sur. Illinois, III, 289565. 1868.)

Description of new species of fossils. F. B. Meek and $A$. H. Worthen. (Geol. Sur. Illinois, V, 323619. 1873.)

Description of new species of fossils. C.'A. White. (Proc. Bost. Soc. Nat. Hist., IX, 8-33. 1865.)

Description of new species of fossils. C. A. White and O. H. St. John. (Trans. Chicago Acad. Sci., I, 115-127. 1867.)

Description of new species of fossils from Iowa rocks. F. B. Meek and A. H. Worthen. (Geol. Sur. Illinois, II, 143-411. 1866.)

Evidence of Two Distinct Geological Formations in the Burlington Limestone. W. H. Niles and 


\section{Burlington Limestone.-Continued.}

Charles Wachsmuth. (Am. Jour. Sci., (2), XLII, 95-99. 1866.) A sketch of the Burlington beds and a list of crinoids found in the upper and lower divisions.

Fish remains in the Carboniferous limestone: A. H. Worthen, (Proc. Am. As. Ad. Sci., X, 189-192. 1856.)

Fossils from the "yellow" sandstone at Burlington, Iowa. A. Winchell. (Proc. Acad. Nat. Sci., Phila., 225. 1863.) Description of new species and genera.

Gasteropods at Burlington, Iowa. C. R. Keyes. (Proc. Acad. Nat. Sci., Phila., 283-289. 1889.) An annotated list.

General description. C. A. White. (Geol. Iowa, I, 201-209. 1870.) Its general characters, distribution, economic value and fossils described.

General description of the eharacters. James Hall. (Geol. Iowa, I, 92-93. 1858.).

Geology and Paleontology of Burlington. C. A. White. (Bost. Jour. Nat. Hist., VII, 209-235. 1860.) Remarks; and descriptions of seven new species.

In Des Moines county. A. H. Worthen. (Geol. Iowa, I, 203. 1858.)

In Henry county. A. H. Worthen. (Geol. Iowa, I; 217. 1858.)

In Lee county. A. H. Worthen. (Geol. Iowa, I, 195-196. 1858.)

In Washington county. A. H. Worthen. (Geol. Iowa, I, 244-245. 1858.) 
Burlington Limestone.-Continucd.

List of fossils found in the Burlington bluff. J. W. Nicollet. (Sen. Doc., 26 Cong., 2nd Sess., V, pt. ii, No. 237. 1841.)

New crinoids from Burlington. F. B. Meek and A. H. Worthen. (Proc. Acad. Nat. Sci., Phila., XX, 335-359. 1868.)

New Bryozoans, E. O. Ulrich. (Geol. Sur. Illinois, VIII, 283-688. 1890.)

New fossils from Iowa. F. B. Meek and A. H. Worthen. (Proc. Acad. Nat. Sci., Phila., XIII, 128148. 1861.)

New species of blastoids from Burlington. F. B. Meek and A. H. Worthen. (Proc. Acad. Nat. Sci., Phila., XXI, 83-91. 1869.)

New species of blastoids from Burlington. F. B. Meek and A. H. Worthen, (Proc. Acad. Nat. Sci., Phila., XXII, 22-56. 1870.)

New species of crinoids from Burlington. F. B. Meek and A. H. Worthen. (Proc. Acad. Nat. Sci., Phila., XVII, 143-166. ' 1865.)

New species of crinoids from Des Moines county. C. A. White. (Bost. Jour. Nat. Hist., VII, 481-506. 1863.)

New species of echinoderms described from Burlington. F. B. Meek and A. H. Worthen. (Proc. Acad. Nat. Sci., Phila., XII, 378-397. 1860.)

New species of fishes described from Iowa. J. S. Newberry and A. H. Worthen. (Geol. Sur. Illinois, II, 9-134. 1866.)

New species of fishes from Iowa. J. S. Newberry and A. H. Worthen. (Geol. Sur. Illinois, IV, 246-374. 1870.) 


\section{Burlington Limestone.-Continued.}

New species of fossils described from Iowa. F. B. Meek and A. H. Worthen. (Proc. Acad. Nat. Sci., - Phila., XII, 447-472. 1860.)

New species of fossils from Iowa. C. A. White. (Rep. Geog. and Geol. Expl. and Surv. W. 100 Merid., IV, 1-219. 1875.)

New species of fossils from Iowa. C. A. White. (Twelfth Ann. Rep. U. S. Geol. and Geog. Sur. Terr., 166-171. 1883.)

New species of fossils from the "Chemung" at Burlington. C. A. White and R. P. Whitfield. (Proc. Boston Soc. Nat. Hist., VIII, 289-316. 1862.)

New Species of Platycrinus and other Fossils from the Mountain Limestone of Illinois and Iowa. A: H. Worthen. (Trans. Acad. Sci., St. Louis, I, 569 . 571. 1860.)

Of Iowa. 'W. J. McGee. (Eleventh Ann. Rep. U. S. Geol. Sur., 312. 1892.). Brief allusion.

Platyceras and its sedentary habits. C. R. Keyes. (Proc. Iowa Acad. Sci., 1890-91, 23. 1892.)

Platyceras on Fossil Crinoids. C. R. Keyes. (Am. Naturalist, XXII, 924. 1888.) Brief notes.

Principal Mississippian Section. G. R. Keyes. (Bul. Geol. Soc. America, III, 283-300. 1892.) The recent investigation along the Mississippi river and the stratigraphical details described with a proposed new classification of the lower Carboniferous rocks in the Mississippi basin.

A Remarkable Fauna at the Base of the Burlington Limestone in Northeastern Missouri. C. R. Keyes. (Am. Jour. Sci., (3), XLIV, 247-252. 1892.) 
Burlington Limestone.-Continued.

Synopsis of American Carbonic Calyptræidæ. C. R.

Keyes. (Proc. Acad. Nat. Sci., Phila., 150-181.

1890.) Descriptions of all the species known.

Transition Forms in Crinoids and Description of Five

New Species. Charles Wachsmuth and Frank Springer. (Proc. Acad. Nat. Sci., Phila., 224-266. 1878.) A sketch of the evolution of certain crinoids, chiefly from southeastern Iowa.

Calciferous Sandstone.

General description of the characters. James Hall. (Geol. Iowa, I, 49-51 1858.)

\section{Calcite.}

Recent finds described in detail. C. R. Keyes. (Proc.

\section{Calhoun County.}

Iowa Acad. Sci., I, pt. iii, 19-22. 1893.)

General account of the surface features. O. H. St.

John. (Geol. Iowa, II, 146-150. 1870.)

Call, R. Ellsworth. Artesian Wells in Iowa. (Proc. Iowa Acad. Sci., 1890-1891, pp. 57-63. Des Moines, 1892. An abstract of notes on artesian wells in Iowa. Sketch-map of their location. Several typical sections given.

Call, R. Ellsworth. A Sketch of the Physical Geography of Iowa. (Annual Report of Iowa Weather and Crop Service, 1890, pp. 12-18. Des Moines, 1891.) A short account of the surface features of Iowa, with map of the chief hydrographic basins of the State.

Call, R. Ellsworth. Chemistry of Iowa Artesian Waters. (Monthly Rev. Iowa Weather and Crop Service, vol. II, No. 2, pp. 1-5. Des Moines, 1892.) Analyses of the water, as determined by different chemists, of various wells in the State. 
Call, R. Ellsworth. Fossils of the Iowa Loess. (Am. Naturalist, vol. XV, pp. 585-586. Philadelphia, 1881.) Notice of certain species found in the bluff's of the Missouri river.

Call; R. Ellsworth. Iowa Artesian Wells. (Monthly Rev. Iowa Weather and Crop Service, vol. III, No. 3, pp. 1-15. Des Moines, 1892.) A brief sketch of the conditions governing artesian flows, with geological notes of different wells throughout the State. An accompanying sketch-map shows the location of the chief wells:

Call, R. Ellsworth. Loess of North America. (Am. Naturalist, vol. XVI, pp. 369-381. Philadelphia, 1882.) A number of references to the occurrence of loess in Iowa.

Call, R. Ellsworth. Natural Gas in Iowa. (Iowa Weather and Crop Service, vol. III, pp. 6-7. Des Moines, 1892.) Mention of the several reported occurrences of natural gas in Iowa.

Call, R. E., W. J. McGee and. On the Loess and Associated Deposits of Des Moines. (Am. Jour. Sci., (3), XXIV, pp. 202-223. New Haven, 1882.)

Call, Ellsworth R. Preliminary Paper on Artesian Wells in Iowa. (Monthly Review of Iowa Weather and Crop Service, vol. II, No. iv, pp. 1-6. Des Moines, 1891.) A table of the wells of the State, their location, depth and character of the water.

Call, R. Ellsworth. The Loess in Central Iowa. (Am. Naturalist, vol. XV, pp. 782-784. Philadelphia, 1881.) Announcement of its occurrence at Des Moines. Also list of some fossils found in it.

Call, R. E., C. R. Keyes and. On a Quaternary Section Eight Miles Southeast of Des Moines, Iowa. (Proc. 
Call, R. E.-Continued.

Iowa Acad. Sci., 1890-1891, 30. Des Moines, 1892.) Description of a section near the terminal moraine near Des Moines.

Calvin, S. Additional Notes on the Devonian Rocks of Buchanan Gounty, Iowa. (Am. Geologist, vol. VIII, pp. 142-145. Minneapolis, 1891.) A detailed description of the different beds belonging to the Devonian, as found in Buchanan county.

Calvin, S. Description of a New Species of Spirifera from the Hamilton Group, near Iowa City, Iowa. (Bul. Lab. Nat. Hist., State Univ. Iowa, vol. I, pp. 28-29. Iowa City, 1888.) Spirifera urbana described as new.

[Calvin, S.] Later Cretaceous in Iowa. (Am. Geologist, vol. I, p. 237. Minneapolis, 1888.) A short note on the Cretaceous fossils found in the drift near Mt. Vernon, in Linn county.

Calvin, S. New Species and New Genus of Tubicolar Annelida. (Am. Geologist, vol. I, pp. 24-28: 1888.) An account and description of a worm found infesting the Devonian corals near Iowa City. The following genus and species described as new:

Streptindytes.

Streptindytes acervularix.

Calvin, S. Note on the Difference between Acervularia profunda, Hall, and Acervularia davidsoni, Edwards and Haime. (Proc. Iowa Acad. Sci., 1890-1891, 30-32. Des Moines, 1892.) A short account of the difference between the two species at. Independence, Iowa, and elsewhere.

Calvin, S. Note on the Difference between Acervularia profunda, Hall, and Acervularia davidsoni, Edwards and Haime. (Am. Geol., vol. IX, pp. 355-358. Minne- 
Calvin, S.-Continued.

apolis, 1892.) A short account of the difference between the two species at Independence, Iowa, and elsewhere.

Calvin, S. Notes on a Collection of Fossils from the Lower Magnesian Limestone, from Northeastern Iowa. (Am. Geologist, vol. X, pp. 144-148. 1892.) Short notes on various fossils. The following species, without figures, described as new :

Straparollus claytonensis.

Straparollus pristiniformis.

Raphistoma multivolvatum.

Raphistoma paucivolvatum.

Cyrtoceras luthei.

Calvin, S. Notes on the Formations Passed Through in Boring the Deep Well at Washington, Iowa. (Am. Geologist, vol. I, pp. 28-31. 1888.) Short notes on the formations passed through in sinking a well at Washington.

Calvin, S. Notes on the Geological Formations of Iowa. (Pamphlet, printed at World's Exposition at New Orleans, pp. 1-8. 1884.) A brief résumé of the geological formations of the State.

Calvin, S. Notes on the Synonymy, Characters and Distribution of Spirifera parryana, Hall. (Bul. Lab. Nat. Hist. State Univ. Iowa, vol. I, pp. 19-28. Iowa City, 1888.) All the related species of Spirifera parryana described from the Iowa formations considered to be synonyms of this species.

Calvin, S. On some Dark Shale recently Discovered below the Devonian Limestones, at Independence, Iowa; with a Notice of its Fossils and Description of new Species. (Bulletin United States Geol. and Geog. 
Calvin, S.-Continued.

Sur.'Terr., vol. IV, pp. 725-730. 1878.) A short account of the rocks of the locality, with remarks on some of the fossils. The following species are regarded as new :

Strophodonta variablis.

Strophodonta quadrata.

Orthis infera.

Rhynchonella ambigua.

Gypidula munda.

[Calvin, S.] On the Chert of the Upper Coal Measures in Montgomery County, Iowa. (Am. Geologist, vol. I, pp. 116-117. Minneapolis, 1888.) A brief comparison of Iowa cherts with those of Ireland.

Calvin, S. On the Fauna found at Lime Creek, Iowa, and its relation to other Geological Faunas. (Amer. Jour. Sci., (3), vol. XXV, pp. 434-436. 1883.) A criticism on Williams' paper on the same subject, with additional notes and a description of Spirifera macbridei, regarded as new.

Calvin, S. Some Geological Problems in Muscatine County, Iowa. (Bul. Lab. Naț. Hist. State Univ. Iowa,

- vol. I, pp. 7-18. Iowa City, 1888.) A description of certain rocks about Muscatine, showing that they are Devonian instead of lower Carboniferous. Numerous references to fossils given.

Calvin, S. Relation of the Cretaceous Deposits of Iowa to the Subdivisions of the Cretaceous proposed by Meek and Hayden. (Proc. Iowa Acad. Sci.,vol. I, pt. iii, pp. 7-12. Des Moines, 1893.) The Cretaceous deposits in the vicinity of Sioux City described in detail.

Calvin, S. Some Geological Problems in Muscatine County, Iowa, with Special Reference to the Rectifica- 
Calvin, S.-Continuèd.

tion of the Supposed Kinderhook near the Mouth of Pine Creek. (Am. Geologist,vol. III, pp. 25-36. Minneapolis, 1889.) Special account of certain yellow sandstones in Muscatine county, formerly referred to the Kinderhook, but now shown to be Devonian in age. Calvin, S. Some New Species of Paleozoic Fossils. (Bul. Lab. Nat. Hist. State Univ. Iowa, vol. I, pp. 173-181. Iowa City, 1890.) The following species described as new :

Terebratula iowensis.

Schizodus symmetricus.

Holopea grandis.

Straparollus lativolvis.

Straparollus bicarinatus.

Straparollus tricarinatus.

Calvin, S. Structure and Probable Affinities of Cerionites Dactylioides, Owen. (Proc. Iowa Acad. Sci., vol. I, part iii, pp. 13-15. Des Moines, 1893.) The structure. of the fossils described in detail and an ideal restoration made.

\section{Cambrian.}

Brief general account. W. J. McGee. (Eleventh Ann. Rep. U. S. Geol. Sur., 333-334. 1892.)

Correlation of Potsdam rocks in northeastern Iowa.

C. D. Walcott. (Bul. 81, U. S. Geol. Sur., 187188. 1891.)

Description of the lower sandstone of the Upper Mississippi (Potsdam). D. D. Owen. (Geol. Sur. Wis., Iowa and Minn., 48-58. 1852.) A detailed account of its lithological characters, range and paleontology.

Capellini, J., et O. Heer. Les Phyllites Crétacees du Nebraska. (Mém. Soc. Helvétique des Sci. nat., t. 
Capellini, J.-Continued.

XXII, pp. 1-24. 1867.) Description of the Cretaceous deposits of the upper Missouri region.

Carboniferous (Lower).

Age of Certain Sandstones near Iowa City. C. R. Keyes. (Proc. Iowa Acad. Sci., 1890-1891, 26. 1892.) Owing to the recent discovery of fossils in the sandstones near. Iowa City, the suggestion is made that their age may be Kinderhook (lower Carboniferous) instead of Upper Coal Measures as have been heretofore regarded.

Artesian Wells in Iowa. R. E. Call. (Proc. Iowa Acad. Sci., 1890-1891, 57-63. 1892.) A description of a well in the Carboniferous.

Attachment of Platyceras to Palæocrinoids. G. R.

Keyes. (Am. Philosophical Soc., XXV, 231-243. 1888.) Description of examples recently found showing attachment of gasteropod to crinoids. Four new species described.

Brachiopods from various localities in Iowa. J. Hall.

(Nat. Hist. New York, Pal., VIII, 1-367. 1892.)

Brachiopods mentioned from Iowa. R. P. Whitfield.

(Bul. Am. Mus. Nat. Hist., I, 39-97. 1882.)

Brecciated Character of the St. Louis Limestone. C.

H. Gordon. (Am. Naturalist, XXIV, 303-313: 1890.)

Brief general account. W. J. McGee. (Eleventh Ann. Rep. U. S. Geol. Sur., 312. 1892.)

Brief geological description. C. A. White. (Geol. Iowa, I, 189-230. 1870.) An account of the general characters and leading subdivisions, the last being as follows: Chester, St. Louis, Keokuk, Upper and Lower Burlington, Kinderhook. Each 
Carboniferous (Lower).-Continued.

of these then receives special consideration. (See under these titles.) A full description of the unconformability of the coal measures upon the older rocks and of the St. Louis limestone upon the older formations of the subcarboniferous group.

Carboniferous Echinodermata of the Mississippi Basin. C. R. Keyes. (Am. Jour. Sci., (3), XXXVUI, 186193. 1889.) Synoptical table and remarks on the distribution of the crinoids and their range in the lower Carboniferous rocks of the Mississippi valley.

Carboniferous Limestone of the Mississippi Valley. J. Hall. (Proc. Am. As, Ad. Sci., X, 51-69. 1857.)

Catalogue of the Paleozoic Fossils of North America. B. F. Shumard. (Trans. Acad. Sci., St. Louis, II, 334-407. 1866.)

Certain Forms of Straparollus from Southeastern Iowa. C. R. Keyes. (Am. Geologist, V, 193-197. 1890.): Certain sandstones of Muscatine county referred to the Devonian instead of the Lower Carboniferous. S. Calvin. (Am. Geologist, III, 25-36. 1889.)

Character of the Unconformability of the Iowa Coal Measures upon the Older Rocks. G. A. White. (Am. Jour. Sei., (2), XLV, 331-334. 1868.)

Classification of Crinoids. C. R. Keyes. (Am. Naturalist, XXIII, 153. 1889.) Remarks on the changes necessitated by the discovery of the ventral structure of Taxocrinus (from Marshalltown, Iowa).

Classification of the Lower Carboniferous Rocks of the Mississippi Valley. C. R. Keyes. (Washington; Judd and Detweiller, prịnters, 1-24. 1892.) Sections and details of the rocks in southeastern Iowa. Correlation of the rocks in Iowa. H. S. Williams. 
Carboniferous (Lower).-Continued.

(Buil. 80, U. S. Geol. Sur., 1-279. 1891.) Numer- . ous references.

Crinoids from Iowa. A. H. Worthen. (Geol. Sur. Illinois, VII, 264-322. 1883.)

Description of Burlington fossils. James Hall. (Geol. Iowa, I, 524-605. 1858.)

Description of fossil fishes. O. H. St. John and A. H.

Worthen. (Geol. Sur. Illinois, VII, 53-264. 1883.)

Description of Keokuk fossils. James Hall. (Gëol. Iowa, I, 606-667. 1858.)

Description of Kinderhook fossils. James Hall. (Geol. Iowa, I, 517-523. 1858.)

Description of new fossils. A. H. Worthen. (Geol. Surv. Illinois, VIII, 69-154. 1890.)

Description of new species of Cephalopods. D. D. Owen. (Rep. Geol. Sur.Wis., Iowa and Minn., App., Art. i, 581. 1852.)

Description of new species of Grinoidea. J. Hall. (Bost. Jour. Nat. Hist., VII, 251-328. 1861.)

Description of New Species of Crinoids. D. D. Owen and B. F. Shumard. (Rept. Geol. Sur. Wis., Iowa and Minn., App., Art. ii, 587-598. 1852.)

Description of new species of crinoids. A.H. Worthen. (Illinois State Mus. Nat. Hist., Bul. No. 1, 1-39. 1882.)

Description of new species of crinoids from Burlington. F. B. Meek and A. H. Worthen. (Proc. Acad. Nat. Sci., Phila., XXI, 67-83. 1869.)

Description of new species of echinoderms. F. B. Meek and A. H. Worthen. (Proc. Acad. Nat. Sci., Phila., XIX, 251-275. 1868.)

Description of new species of echinoderms. S. A. Miller and W. F. E. Gurley. (Pamphlet, 59 pp. 1890.) 
Carboniferous (Lower).-Continued.

Description of new species of fishes. O.H. St. John and A. H. Worthen. (Geol. Sur. Illinois, VI, 245288. 1875.)

Description of new species of fossils. F. B. Mreek and A. H. Worthen. (Geol. Sur. Illinois, III, 289-565. 1868.)

Description of new species of fossils. F. B. Neek and A. H. Worthen. (Geol. Sur. Illinois, V, 323-619. 1873.)

Description of new species of fossils. C. A. White. (Proc. Bost: Soc. Nat. Hist., IX, 8-33. 1865.)

Description of new species of fossils. C. A. White and O. H. St. John. (Trans. Chicago Acad. Sci., I, 115127. 1867.)

Description of new species of fossils from Iowa rocks. F. B. Meek and A.H. Worthen. (Geol. Sur. Illinois, II, 143-411. 1866.)

Deseription of new species of fossils from the "Chemung" group, at Burlington, Iowa. C. A. White and R: P. Whitfield. (Proc. Jour. Nat. Hist., VIII, 289-306. 1862.) Brief remarks on the rocks, with descriptions of new fossils.

Deseription of the rocks in southeastern Iowa. D. D. Owen. (Rep. Geol. Sur. Wis., Iowa and Minn., 90-105. 1852.)

Description of St. Louis fossils. James Hall. (Geol. Iowa, I, 667-677. 1858.)

Discovery of the Ventral Structure of Taxocrinus and Haplocrinus; and Consequent Modifications in the Classification of the Crinoidea. C. Wachsmuth and F. Springer. (Proc. Acad. Nat. Sci., Phila., 1888, 337-363. 1888.) Recent discoveries at Marshalltown noted and described. 
Carboniferous (Lower).-Continued.

Evidence of Two Distinct Geological Formations in the Burlington Limestone. W. H. Niles and Charles Wachsmuth. (Am. Jour. Sci., (2, XLII, 95-99. 1866.) A sketch of the Burlington beds and a list of crinoids found in the upper and lower divisions. Fossils from the yellow sandstone below the Burlington limestone at Burlington, Iowa. A. Winchell. (Proc. Acad. Nat. Sci., Phila.. 1863, 2-25. 1864.) Descriptions of new species and genera found in the yellow sandstone at Burlington.

Fish remains in the Carboniferous limestone. A. $\mathrm{H}$. Worthen. (Proc. Am. As. Ad. Sci., X, 189-192. 1856.)

Fossil wood from the Keokuk formation, Keokuk, Iowa. S. J. Wallace. (Am. Jour. Sci., (3), XV, 396. 1878.)

Gasteropods from Burlington. G. R. Keyes. (Proc. Acad. Nat: 'Sci., Philadelphia, 1889, 283-298.) Species are from the Kinderhook and Burlington limestone.

Gasteropods from Iowa. J. Hall. (Nat. Hist. New York, Pal., V, pt, ii. 1879.) A number of references to fossils from Iowa.

General description of the Burlington limestone. C. A. White. (Geol. Iowa, I, 201-209. .1870.) Geology and Paleontology of Burlington and Vicinity. C. A. White. (Boston Jour. Nat. Hist., vol. VII, pp. 209-235. 1860.) Detailed remarks on the geological section, with list of species, seven described as new.

In Des Moines county. A. H. Worthen. (Geol. Iowa, I, 201-206. 1858.) 
BIBLIOGRAPHY.

Carboniferous (Lower).-Continued.

In Franklin county. C. A. White. (Geol. Iowa, II, 240. 1870.)

In Hamilton county. C. A. White. (Geol. Iowa, II, 256-257. 1870.)

In Humboldt county. C. A. White. (Geol. Iowa, II, 244. 1870.)

In Marion county. C. A. White. (Geol. Iowa, II, 203-265. 1870.)

In Van Buren county. A. H. Worthen. (Geol. Iowa, I, 226-228. 1858.)

In Wapello county. A. H. Worthen. (Geol. Iowa, I, 254-255. 1858.)

In Washington county. A. H. Worthen. (Geol. Iowa, I, 242-246. 1858.)

Keokuk Beds and Their Contained Fossils in the Vicinity of Keokuk, Iowa. C. H. Gordon. (Proc. Iowa Acad. Sci., I, 98-100. 1880.)

Keokuk group of the Mississippi valley. C. S. Beachler. (Am. Geologist, X, 88-96. 1892.)

Lamellibranchiata. James Hall. (Nat. Hist. New York, Pal., V, pt. i, second half. 1885.) A number of species of fossils from Iowa noted.

List of fossils found in the Burlington bluff. J. N. Nicollet. (Sen. Doc., 26 Cong., 2nd Sess., V, pt. ii, No. 237. 1841.)

Marshall Group: A Memoir on its Geological Position, Characters and Equivalencies in the United States. A. Winchell. (Proc. Am. Phil. Soc., XI, 57-83. 1890.)

New Bryozoans. E. O. Ulrich. (Geol. Sur. Illinois, VIII, 283-688. 1890.)

New erinoids from the Burlington. F. B. Meek and 1) G. Rep. 
Carboniferous (Lower).-Continued.

A. H. Worthen. (Proc. Acad. Nat. Sci., Phila., XX, 335-359. 1868.)

New Fossil Crinoidea from the Paleozoic Rocks of the Western and Southern Portions of the United States. B. F. Shumard. (Trans. Acad. Sci., St. Louis, I, 71-80. 1858.)

New fossils from Iowa. F. B. Meek and A. H. Worthen. (Proc. Acad. Nat. Sci., Phila., XIII,..128148. 1861.)

New Species of Blastoidea from the Paleozoic Rocks of the Western States. B. F. Shumard. (Trans. Acad. Sci., St. Louis, I, 238-248. 1858.)

New species of blastoids from Burlington. F. B. Meek and A. H. Worthen. (Proc. Acad. Nat. Sei., Phila., XXI, 83-91. 1869.)

New species of Brachiopods from Burlington. A. Winchell. (Proc. Acad. Nat. Sci., Phila., XVII, 109-133. 1865.)

New species of crinoids from the Burlington limestone. R. P. Whitfield. (Bul. Am. Mus. Nat. Hist., I, 7-9. 1881.)

New species of crinoids from Burlington. F. B. Meek and A. H. Worthen. (Proc. Acad. Nat. Sci., Phila., XVII, 143-166. 1865.)

New species of crinoids from Des Moines county. C. A. White. (Boston Jour. Nat. Hist., VII, 481-506. 1863.)

New species of crinoids from Marshall county. C. Wachsmuth and F. Springer. (Geol. Surv., Illinois, VIII, 157-251. 1890.)

New species of echinoderms described from Burlington. F. B. Meek and A. H. Worthen. (Proc. Acad. Nat. Sci., Phila., XII, 378-397. 1860.) 
Carboniferous (Lower).-Continued.

New species of fishes described. J. S. Newberry and A. H. Worthen. (Geol. Sur. Illinois, II, 9-134. 1866.)

New species of fishes from Iowa. J. S. Newberry and A. H. Worthen. (Geol. Sur. Illinois, IV, 246-374. 1870.)

New species of fossils. C. A. White. (Proc. Acad. Nat. Sci., Phila., XXVII, 27-34. 1877.)

New species of fossils described from Iowa. F. B. Meek and A. H. Worthen. (Proc. Acad. Nat. Sci., Phila., XII, 447-472. 1860.)

New species of fossils from Iowa. C. A. White. (Rep. Geog. and Geol. Expl. and Surv. W. 100 Merid., IV, 1-219. 1875.)

New species of fossils from Iowa. C. A. White. (Twelfth Ann. Rep. U. S. Geol. and Geog. Sur. Terr., 155-181. 1883.)

New species of fossils from Iowa. A. H. Worthen and F. B. Meek. (Geol. Sur. Illinois, VI, 489-532. 1875.)

New species of Polyzonns. A. H. Prout. (Geol. Sur. Illinois, II, 412-424. 1866.)

New species of sponges from the Keokuk. E. O. Ulrich. (Geol. Surv. Illinois, VIII, 243-251. 1890.) Observations upon the Carboniferous Limestones of the Mississippi Valley. J. Hall. (Am. Jour. Sci., (2), ХХШ 187-203. 1857.)

Observations on the Genus Archimedes. J. Hall. (Proc. Am. As. Ad. Sci., 170-180. 1857.)

Observations on the Keokuk Species of Agaricocrinus. C. H. Gordon. (Proc. Iowa Acad. Sci., 100-101. 1880.) 
Carboniferous (Lower)._Continued.

Platyceras and its sedentary habits. C. R. Keyes. (Am. Jour. Sci., XXXVI, 269-272. 1889.) Notes on species found in the lower Carboniferous of Iowa. Principal Nississippian Section. C. R. Keyes. (Bul. Geol. Soc. America, III, 283-300. 1892.) The recent investigations along the Mississippi river and the stratigraphical details described, with a proposed new classification of the lower Carboniferous rocks in the Mississippi basin.

Platyceras Attached to Fossil Crinoids. C. R. Keyes. (Am. Naturalist, XXII, 924-925.) Statement of the association of certain species found in Iowa.

Remarkable Fauna at the Base of the Burlington Limestone in Northeastern Missouri. C. R. Keyes. (Am. Jour. Sci., (3), XLIV, 247-252. 1892.)

Remarks on the Age of the Goniatite Limestone at Rockford, Indiana, and its Relations to the Black Slate of the Western States and to some of the Succeeding Rocks of the latter. F. B. Meek and A. H. Worthen. (Am. Jour. Sci., (2), XXXII, 167-177. 1861.)

Some Geological Problems of Muscatine County. S. Calvin. (Bul. Lab. Nat. Hist. State Univ. Iowa, I, 7-18. 1888.) Certain rocks in the locality shown to be Devonian instead of Kinderhook as was formerly supposed by Hall.

Synopsis of American Carbonic Calyptræidæc. C. R. Keyes. (Proc. Acad. Nat. Sci., Phila., 150-181. 1890.) Descriptions of all the species known.

Transition Forms in Crinoids and Description of Five New Species. Charles Wachsmuth and Frank Springer. (Proc. Acad. Nat. Sci., Phila., 224-266. 
Carboniferous (Lower).-Continued.

1878.) A sketch of the evolution of certain crinoids, chiefly from southeastern Iowa.

Unconformity of the Coal Mensures upon the underlying rocks. J. Hall. (Proc. Am. As. Ad. Sci., X, 51-69. 1857.)

Variation of a Gasteropod. C. R. Keyes. (Am. Geologist, III, 329-333. 1889.) Specimens from Keokuk limestone at Keokuk figured and referred to.

Wood found. C. H. Gordon. (Proc. Iowa Acad. Sci., 97-98. 1890.)

Carboniferous (Upper).

Age of Certain Sandstones near Iowa City. C. R. Keyes. (Proc. Iowa Acad. Sci., 1890-1891, 26. 1892.) Owing to the recent discovery of fossils in the sandstones near Iowa City the suggestion is made that their age may be Kinderhook (lower Carboniferous) instead of upper Coal Measures as have been heretofore regarded.

Brachiopods from various locálities in Iowa. J. Hall. (Nat. Hist. New York, Pal., V̇II, 1-367. 1892.)

Brick and Other Clays of Des Moines. C. R. Keyes. (Proc. Iowa Acad. Sci., -1890-1891, 29. 1892.) A brief statement of the clay industries at Des MLoines.

Brief general account. W. J. McGee. (Eleventh Ann. Rep. U. S. Geol. Sur., 308-312. 1892.)

Chert of the Upper Coal Measures in Montgomery County. S. Galvin. (Am. Geologist, I, 116-117. 1888.)

Classification of the Lower Carboniferous Rocks of the Mississippi Valley. C. R. Keyes. (Washington : Judd and Detweiller, printers, 1-24. 1892.) Allusions to the Coal Measures in central Iowa. 
Carboniferous' (Upper).-Continued.

Coal Measures of Central Iowa. C. R. Keyes. Am. Geologist, II, 396-409.) Sketch of the geology of Des Moines.

Contribution to the Fauna of the Lower Coal Measures of Central Iowa. C. R. Keyes. (Proc. Iowa Acad. Sci., 1890-1891, 22-23. 1892.) A preliminary note. Three species described from the Lower Coal Measures at Des Moines.

Correlation of the rocks in Iowa. H. S. Williams. (Bul. 80, U. S. Geol. Sur., 1-279. 1891.) Numerous references.

Description of Middle Coal Measures. O. H. St. John. (Geol. Iowa, I, 264-284. 1870.)

Description of new fossils. C. A. White and O. H. St. John. (Pamphlet, pp. 1-3. Iowa City, 1867.)

Description of New Species of Fossils. C. A. White and O. H. St. John. (Trans. Chicago Acad., Sci., I, 115-127. 1867.)

Description of new species of fossils from Iowa rocks.

F. B. Meek and A. H. Worthen. (Geol. Sur. Illinois, $\Pi, 143-411$. 1866.)

Description of the Lower Coal Measure fossils. James Hall. (Geol. Iowa, I, 711-724. 1858.)

Description of the rocks along the Des Moines river. D. D. Owen. (Rep. Geol. Sur. Wis., Iowa and Minn., 105-133. 1852.)

Description of the Rocks in Eastern Kansas and Nebraska and their Relation to those of Adjacent States, etc. F. B. Meek. (Am. Jour. Sci., (2), XXXIX, 157-174. 1865.) Numerous incidental references to the geology of western Iowa.

Fauna of the Lower Coal Measures of Central Iowa. 
Carboniferous (Upper).-Continued.

C. R. Keyes. (Proc. Acad. Nat. Sci., Phila., 231247. 1888.)

Folding of the Carboniferous Strata in Southwestern Iowa. J. E. Todd. (Proc. Iowa Acad. Sci., 18871889, 58. 1890.)

Fossil Faunas in Central Iowa. C. R. Keyes. (Proc. Acad. Nat. Sci., Phila., 242-265. 1891.) Notes and bibliographic references to the species found in the lower Coal Measures in the central part of the State.

Fossils from Jackson County. Herbert Osborn. (Proc. Iowa Acad. Sci., 1890-1891, 115. 1892.) Lepidodendron and Calamites reported from a Coal Measure pocket in Jackson county.

Fossils from the Lower Coal Measures at Des.Moines, Iowa. C. R. Keyes. (Am. Geologist, II, 23-28. 1888.) List, and brief remarks on the rocks containing the species.

Fossils in Iowa drift. C. A. White. (Geol. Iowa, I, 98. 1870.)

General description. C. A. White. (Geol. Iowa, I, 231-285. 1870.) The general characters briefly considered, the economic value and animal remains of the different divisions described, with sections and practical remarks.

Geological Structure and Relations of the Coal-bearing Strata of Central Iowa. C. R. Keyes. (Proc. Iowa Acad. Sci., 1890-1891, 27-28. 1892.) A summary of observations made along the Des Moines river, chiefly in the vicinity of Des Moines.

Geology of Eastern Nebraska. F. V. Hayden. (U. S. Geol. Sur. of Nebraska, 1-79. 1872.) Incidental remarks on the geology of western Iowa. 
Carboniferous (Upper).-Continued.

Geology of the western states. D. D. Owen. (Am. Jour. Sci., (3), XLV, 151-153. 1843.) . Incidental references to Iowa coal fields.

In Adair county. G. A. White. (Geol. Iowa, I, 337339. 1870.)

In Adams county. C. A. White. (Geol. Iowa, I, 340343. 1870.)

In Cass county. C. A. White. (Geol. Iowa, I, 373375. 1870.)

In Dallas county. O. H. St. John. (Geol. Iowa, II, 13-46. 1870.)

In Decatur county. G. A. White. (Geol. Iowa, I, 320-325. 1870.)

In Des Moines county. A. H. Worthen. (Geol. Iowa, I, 200-201. 1858.)

In Fremont county. C. A. White. (Geol. Iowa, I, 357-360. 1870.)

In Greene county. O. H. St. John. (Geol. Iowa, II, 134-138. 1870.)

In Guthrie county. O. H. St. John. (Geol. Iowa, II, 105-129. 1870.)

In Hamilton county. C. A. White." (Geol. Iowa, II, 256-257. 1870.)

In Harrison county. O. H. St. John. (Geol. Iowa, II, 179-181. 1870.)

In Henry county. A. H. Worthen. (Geol. Iowa, I, 211-214. 1858.)

In Jefferson county. A. H. Worthen. (Geol. Iowa, I, 233-236. 1858.)

In Lee county. A. H. Worthen. - (Geol. Iowa, I, 188-190. 1858.)

In Lucas county. O. H. St. John. (Geol. Iowa, II, 85-95. 1870.) 
Carboniferous (Upper),-Continuel.

In Madison county. C. A. White. (Geol. Iowa, I, 308-315. 1870.) A rather full account, with sections, of geology of the county, with special reference to the coal.

In Mills county. C. A. White. (Geol. Iowa, I, 368370. 1870.)

In Montgomery county. C. A. White. (Geol. Iowa, I, 363-366. 1870.)

In Muscatine county. J. D. Whitney: (Geol. Iowa, I, 274-277. 1858.)

In Page county. C. A. White. (Geol. Iowa, I, 349352. 1870.)

In Pottawattamie county. C. A. White. (Geol. Iowa, I, 378-380. 1870.)

In Ringgold county. C. A. White. (Geol. Iowa, I, 328. 1870.)

In Scott county. A. S. Tiffany. (Geol. Scott County, etc., 30-34. 1885.)

In Taylor county. C. A. White. (Geol. Iowa, I, 347. 1870.)

In Union county. C. A. White. (Geol. Iowa, I, 232234. 1870.)

In Van Buren county. A. H. Worthen. (Geol. Iowa, I, 222-226. 1858.)

In Wapello county. A. H. Worthen. (Geol. Iowa, I, 250-254. 1858.)

In Warren county. O. H. St. John. (Geol. Iowa, II, 46-47. 1870.) .

In Washington county. A. H. Worthen. (Geol. Iowa, I, 241-242. 1858.)

List of fossils from the Des Moines river above the Raccoon fork. J. N. Nicollet. (Sen. Doc., 26 Cong., 2d Sess., V, pt. ii, No. 237. 1841.) 
Carboniferous (Upper).-Continued.

Middle Coal Measures. O. H. St. John. (Geol. Iowa, I, 264-284. 1870.) General description.

New Bryozoans. E. O. Ulrich. (Geol. Sur. Illinois, VIII, 283-688. 1890.)

New species of fossils described from Iowa. F. B. Meek and A. H. Worthen. (Proc. Acad. Nat. Sci., Phila., XII, 447-472. 1860.)

New Species of Paleozoic Fossils. S. Calvin. (Bul. Lab. Nat. Hist. State Univ. Iowa, I, 176. 1890.)

Notes on the Redrock Sandstone. C. R. Keyes. (Proc. Iowa Acad. Sci., 1890-1891, 26-27. 1892.) Preliminary references to the stratigraphical relations of a thick sandstone formation in Marion county.

Paleontology of Eastern Nebraska. F. B. Meek. (U. S. Geol. Surv. of Nebraska, 83-245. 1872.) Numerous incidental references to the occurrence of fossils in Upper Coal Measures of Iowa.

Redrock sandstone of Marion County, Iowa. C. R. Keyes. (Am.Jour. Sci.(3), XLI, 273-276. 1891.) A description of the formation and its unconformities.

Remarks on Prof. Geinitz's Views Respecting the Upper Paleozoic Rocks and Fossils of Southeastern Nebraska. F. B. Meek. (Am. Jour. Sci., (2), XLIV, 170-187. 1867.) Numerous incidental references to the geology of western Iowa.

Rocks of southwestern Iowa shown to be of this age instead of Lower Carboniferous. C. A. White. (Am. Jour. Sci., (2), XLIV, 23-31. 1867.)

Stratigraphy of the Carboniferous of Central Iowa. C. R. Keyes. (Bul. Geol. Soc. America, II, 277292.) Description of the stratigraphical relations 
Carboniferous (Upper).-Continued.

of the various beds in the central part of the State. Synopsis of American Carbonic Calyptræidx. C. R.

Keyes. (Proc. Acad. Nat. Sci., Phila., 150-181.)

Descriptions of all the species found.

Unconformable on the underlying strata. J. Hall. (Proc. Am. As. Ad. Sci., X, 51-69. 1857.)

\section{Carroll County.}

General description. O. H. St. John. (Geol. Iowa,

II, 138-146. 1870.) The surface features and gen-

- eral geology briefly described, with several sections.

\section{Cass County.}

General geological characters. C. A. White. (Geol. Iowa, 371-376. 1870.) The drainage, surface characters and geology briefly given, with several sections.

Notes on the surface features. C. A. White. (First Ann. Rep. State Geologist, 65-66. 1868.)

Catalogue of all the Recorded Meteorites; with Description of the Specimens in the Harvard College Collection, Including the Cabinet of the late J. Lawrence Smith. O. W. Huntington. (Proc. Am. Acad. Art and Sci., New Ser., XV, 37-110. 1887.)

Catalogue of the Paleozoic Fossils of North America. B. F. Shumard. (Trans. Acad. Sci., St. Louis, II, 334-407. 1866.)

Caverns.

General remarks. C. A. White. (Geol. Iowa, I, 8081. 1870.) A few of the best known briefly considered.

Cedar County.

Analyses of peat. Rush Emery. (Geol. Iowa, II, 397. 1870.) 
Cedar County.-Continued.

Geological notes. J. D. Whitney. (Geol. Iowa, I, 278-282. 1858.)

\section{Cedar Valley Limestone.}

Of northeastern Iowa. W. J. McGee. (Eleventh Ann. Rep. U. S. Geol. Sur., 314-320. 1892.)

\section{Celestite.}

Its occurrence near Ft. Dodge. C. A. White. (Geol. Iowa, II, 304. 1870.)

\section{Cephalopods.}

Description of new species. D. D. Owen. (Rep. Geol. Sur. Wis., Iowa and Minn., App., art. i, 581. 1852.) Description of new species from Iowa rocks. F. B. Meek and A. H. Worthen. (Geol. Sur. Illinois, II. 143-411. 1866.)

From eastern Nebraska. F. B. Meek. (Final Report

U. S. Geol. Sur. Nebraska, pt. ii, 83-245. 1872.)

Lower Carboniferous and Coal Measure species. C.

A. White and O. H. St. John. (Trans. Chicago Acad. Sci., I, 115-127. 1867.)

New species from Burlington. A. Winchell. (Proc. Acad. Nat. Sci., Phila., 225. 1863.)

New species from Paleozoic rocks of Iowa. C. A. White. (Proc. Acad. Nat. Sei., Phila., XXVIII, 27-34. 1877.)

New species from the Carboniferous of Iowa. F. B. Meek and A. H. Worthen. (Proc. Acad. Nat. Sci., Phila., XII, 447-472. 1860.)

New species from the Devonian at Davenport. W. H. Barris. (Proc. Davenport Acad. Nat. Sci., II, 282-288. 1878.)

Of central Iowa. C. R. Keyes. (Proc. Acad. Nat. Sci., Phila., 231-247. 1888.) 
BIBLIOGRAPIY.

\section{Cerro Gordo County.}

Analyses of peat. Rush Emery. (Geol. Iowa, II, 398-399. 1870.)

Distribution of Rockford shales. C. L. Webster. (Proc. Davenport Acad. Nat. Sci., V, 100-109. 1887.)

General description. C. A. White. (Geol. Iowa, II, 249-251. 1870.)

Notes on the Rockford Shales. C. L. Webster. (Am. Naturalist, XXII, 444-446. 1888.)

Certain Forms of Straparollus from Southeastern Iowa. C. R. Keyes. (Am. Geologist, V, 193-197. 1890.)

Chamberlin, T. C. Ore Deposits of Southwestern Wisconsin. (Geol. Sur. Wisconsin, vol. IV, pp. 367-568. . Madison, 1882.) A number of incidental references to the occurrence of lead and zinc in Iowa, with maps showing localities of the diggings.

Chamberlin, T. C. Terminal Moraine of the Second Glacial Epoch. (U. S. Geol. Sur., Third Ann. Rep., pp. 291-404. Washington, 1883.) Incidental references to the drift deposits of Iowa.

Chamberlin, T. C. The Rock Scorings of the Great Ice Invasions. (U. S. Geol. Sur., Seventh Ann. Rep., pp. 147-248. Washington, 1888.) A number of references to the glacial phenomena in Iowa.

Chamberlin, T. C., and R. D. Salisbury. Preliminary Paper on the Driftless Area of the Upper Mississippi Valley. (U. S. Geol. Sur., Sixth Ann. Rep., pp. 199322. Washington, 1886.) A number of references to the surface geology of Iowa, with several maps showing the distribution of ( uaternary formations.

Character of the Unconformability of the Iowa Coal Measures upon the Older Rocks. C. A. White. (Am. Jour. Sci., (2), XLV, 331-334. 1868.) 
Charcoal Streak in the Loess. J. E. Todd. (Proc. Iowa Acad. Sei., 21. 1880.)

Charleston Earthquake of August 31, 1886 . C. E. Dutton. (U. S. Geol. Sur., Ninth Ann. Rep., 205-528. 1889.)

Check-List of the Paleozoic Fossils of Wisconsin, Minnesota, Iowa, Dakota and Nebraska. B. Bierbauer. (Bul. Minnesota Acad. Nat. Sci., II, 206-247. 1888.) Chemical Analyses of coal from various counties. Rush Emery. (Geol. Iowa, II, 357-395. 1870.)

Chemical Report of the Geological Survey of Iowa. R. Emery. (Geol. Iowa, II, 343-402. 1870.)

Chemistry and Economical Geology. J. D. Whitney. (Geol. Iowa, I, 324-472. 1858.)

Chemistry of Iowa Artesian Waters. R. E. Call. (Monthly Rev. Iowa Weather and Crop Service, II, No. 2, 1-5. 1892.)

\section{Chemung Group.}

General description of the characters. James Hall:(Geol. Iowa, I, 88-91. 1858.)

In Lee county. A. H. Worthen. (Geol. Iowa, I, 196. 1858.)

In Scott county. A. S. Tiffany. (Geol. Scott County, etc., 27-30. 1885.)

Cherokee County.

General description. C. A. White. (Geol. Iowa, II, 223-226. 1870.) Mere reference to the surface features.

Chickasaw County.

Notice of the geology. J. D. Whitney. (Geol. Iowa, I, 306-311. 1858.)

Cincinnati Group.

General description. C. A. White. (Geol. Iowa, I, 
Cincinnati Group.-Continued.

180-182. 1870.) The general characters, economic value and geological age described briefly.

Of northeastern Iowa. W. J. McGee. (Eleventh Ann. Rep. U. S. Geol. Sur., 326-327. 1892.)

Clarke County.

General description. C. A. White. (Geol. Iowa, I, 316-318. 1870.) Brief reference to the geology and economic resources.

Classification of the Crinoidea. C. R. Keyes. (Am. Naturalist, XXIII, 153. 1889.)

Classification of the Lower Carboniferous Rocks of the Mississippi Valley. C. R. Keyes. (Pamphlet, Washington: Judd and Detweiller, printers, 1-24. 1892.)

Clay.

Brick and Other Clays of Des Moines. C. R. Keyes. (Proc. Iowa Acad. Sci., 1890-1891, 29. 1892.) A brief statement of the clay industries at Des Moines.

Properties. C. A. White. (Geol. Iowa, II, 323-328. 1870.) A short account of some of the properties of Iowa clays.

Analyses. Rush Emery. (Geol. Iowa, II, 349-350. 1870.)

Clay County.

General description. C. A. White. (Geol. Iowa, II, 224-225. 1870.) Mere reference to the surface features.

Clayton County.

Notes on the geology. J. D. Whitney. (Geol. Iowa, I, 297-302. 1858.)

\section{Climate.}

Of Iowa. J. D. Whitney. (Geol. Iowa, I, 27-34. 1858.) 
Climate.-Continued.

Of Iowa. T. S. Parvin. (Geol. Iowa, I, Ch. iv, 139164. 1870.) A summary of the climatology of the State, based upon observations from 1839 to 1870 , with tables.

\section{Clinton County.}

Geological notes. J. D. Whitney. (Geol. Iowa, I, 278-282. 1858.)

Pockets of fire-clay in Niagara limestone. J. P. Farnsworth. (Am. Geologist, II, 331-334. 1888.)

\section{Clinton Group.}

General description of the characters. James Hall. (Geol. Iowa, I, 70-71. 1858.)

\section{Coal.}

Accounts of various coal mines. P. G. Wilson. (First Biennial Report State Mine Inspector, 1882-1883, 1-92. 1883.)

At Ft. Dodge. C. A. White. (Second Ann. Rep. State Geologist, 140-141. 1868.)

Chemical analyses. J. D. Whitney. (Geol. Iowa, I, 397-414. 1858.)

Chemical analyses. Rush Emery. (Geol. Iowa, II, 357-395. 1870.)

Composition, Valuation and. Proximate Analysis of Iowa Coals. G. Hinrichs. (Second Ann. Rep. State Geologist, 248-268. 1868.)

General description of the characters. James Hall. (Geol. Iowa, I, 120-141. 1858.)

Geological Structure and Relations of the Coal-bearing Strata of Central Iowa. C. R. Keyes. (Proc. Iowa Acad. Sci.; 1890-1891, 27-28. 1892.) A summary of observations made along the Des Moines river, chiefly in the vicinity of Des Moines. 
Coal.-Continued.

In Guthrie county. O. H. St. John. (Geol. Iowa, II, 128-129. 1870.)

In Henry county. A. H. Worthen. (Geol. Iowa, I, 218. 1858.)

In Iowa drift. C. A. White. (Geol. Iowa, I, 97. 1870.)

In Jeffersion county. A. H. Worthen. . (Geol. Iowa, I, 237. 1858.)

In Lucas county. O. H. St. John. (Geol. Iowa, II, 94. 1870.)

In Marion county. C. A. White. (Geol. Iowa, II, 263-265. 1870.)

In north-central Iowa. J. A. Stout. (Fourth Biennial Rep. State Mine Inspectors, 1888-9, 115-151. 1889.)

In Wapello county. A. H. Worthen. (Geol. Iowa, I, 256. 1858.)

In Washington county. A.H. Worthen. (Geol. Iowa, I, 246. 1858.)

Iowa Coal Beds. C. R. Keyes. (Coal Trade Jour., XXXII, 133. March 1, 1893.)

Iowa Coal Beds. C. R. Keyes. (Mon. Rev. Iowa Weather and Crop Service, IV, No. 1, 3-5. 1893.) Mines of central Iowa. J. A. Smith. (Third Biennial Rep. State Mine Inspectors, 1886-1887, 83-112. 1888.)

Mines in north-central Iowa. M. C. Thomas. (Fifth Biennial Rep. State Mine Inspectors, 1890-1891, 95-141. 1891.)

Mines in north-central Iowa. J. A. Stout. (Third Biennial Rep. State Mine Inspectors, 1886-1887, 113-177. 1888.)

Mines in south-central Iowa. James Gildroy. (Fourth Biennial Rep. State Mine Inspectors, 1888-1889, 66114. 1889.) 
Coal.-Continued.

Mines in south-central Iowa. James Gildroy. (Fifth Biennial Rep. State Mine Inspectors, 1890-1891, 5592. 1891.)

Mines in southeastern Iowa. Thomas Binks. (Fifth Biennial Rep. State Mine Inspectors, 1890-1891, 1-51. 1891.)

Mines of southeastern Iowa. Thomas Binks. (Fourth Biennial Rep. State Mine Inspectors, 1888-1889, 1-65. 1889.)

Mines in southeastern Iowa. Thomas Binks. (Third Biennial Rep. State Mine Inspectors, 1886-1887, 1-80. 1888.)

Mines of the State. P. C. Wilson. (Biennial Rep. State Mine Inspector for 1880-1881, 1-165. 1882.) Accounts of the different coal mines of the State.

Mines of the State. P. C. Wilson. (Second Biennial Rep. State Mine Inspector, 1884-1885, 1-116. 1885.) Statistics of Iowa coal product. J.H. Jones. (Rep. Mining Industry in the U. S. at the 11th Census, 1890, 342-422. 1892.)

Coal Measures (Lower).

Brachiopods from various localities in Iowa. J. Hall. (Nat. Hist. New York, Pal., VIII, 1-367. 1892.)

Central Iowa. C. R. Keyes. (Am. Geol., II, 396-404. 1888.) Remarks and description.

Character of the Unconformability of the Iowa Coal Measures upon the Older Rocks. C. A. White. Am. Jour. Sci., (2); ẌLV, 331-334. 1868.)

Classification of the Lower Carboniferous Rocks of the Mississippi Valley. C. R. Keyes. (Washington : Judd and Detweiller, printers, 1-24. 1892.) Allusions to the Coal Measures in central Iowa. 
Coal Measures (Lower).-Continued.

Contribution to the Fauna of the Lower Coal Measures of Central Iowa. C. R. Keyes. (Proc. Iowa Acad. Sci., 1890-1891, 22-23. 1892.) A preliminary note. Three species described from the Lower Coal Measures at Des Moines.

Description of Iowa fossils. James Hall. (Geol. Iowa, I, 711-724. 1858.)

Description of new species of fossils from Iowa rocks. F. B. Meek and A. H. Worthen. (Geol. Sur. Illinois, II, 143-411. 1866.)

Description of the general characters in Iowa. C. A. White. (Geol. Iowa; I, 232-241. 1870.) The general characters, economic value and fossils described.

Description of the rocks along the Des Moines river. D. D. Owen. (Rep. Geol. Sur. Wis., Iowa and Minn., 105-133. 1852.)

Fauna of Central Iowa. C. R. Keyes. (Proc. Iowa Acad. Sci., 22-23. 1892.)

Fossil Faunas in Central Iowa. 'C. R. Keyes. (Proc. Acad. Nat. Sci., Phila., 242-265. 1891.) Notes and bibliographic references to the species found in the lower Coal Measures in the central part of the State.

Fossil wood from the Keokuk formation, Keokuk, Iowa. S. J. Wallace. (Am. Jour. Sci., (3), XV, 396. 1878.)

Geological Structure and Relations of the Coal-bearing Strata of Central Iowa. C.R. Keyes. (Proc. Iowa Acad. Sci., 1890-1891, 27-28. 1892.) A summary of observations made along the Des Moines river, chiefly in the vicinity of Des Moines. 
Coal Measures (Lower).-Continued.

In Des Moines county. A. H.Worthen. (Geol. Iowa, I, 200-201. 1858.)

In Guthrie county. O. H. St. John. (Geol. Iowa, II, 105-106. 1870.)

In Hamilton county. . C. A. White. (Geol. Iowa, II, 256-257. 1870.)

In Henry county. A. H. Worthen. (Geol. Iowa, I, 211-214. 1858.)

In Jefferson county. A. H. Worthen. Geol. Iowa, I, 233-236. 1858.)

In Lee county. A. H. Worthen. (Geol. Iowa, I, 188-190. 1858.)

In Lucas county. O. H. St. John. (Geol. Iowa, II, 81-85. 1870.)

In Muscatine county. J. D. Whitney. (Geol. Iowa, I, 274-277. 1858.)

In Scott county. A. S. Tiffany. (Geol. Scott County, etc., 30-34. ' 1885.)

In Van Buren county. A. H. Worthen. (Geol. Iowa, I, 222-226. 1858.)

In Wapello county. A. H. Worthen. (Geol. Iowa, I, 250-254. 1858.)

In Warren county. O. H. St. John. (Geol. Iowa, II, 46-47. 1870.)

In Washington county. A. H. Worthen. (Geol. Iowa, I, 241-242. 1858.)

List of fossils from the Des Moines river above the Raccoon fork. J. N. Nicollet. (Sen. Doc., 26 Cong., 2d Sess., V, pt. ii, No. 237. 1841.)

Notes on the Redrock Sandstone. C. R. Keyes. (Proc. Iowa Acad. Sci., 1890-1891, 26-27. 1892.) Preliminary references to the stratigraphical relations of a thick sandstone formation in Marion county. 
Coal Measures (Lower).-Continued.

Redrock Sandstone of Marion County, Iowa. J. R. Keyes. (Am. Jour. Sci., (3), XLI, 273-275. 1891.) A description of the formation and its unconformities.

Stratigraphy of the Carboniferous in Central Iowa. C. R. Keyes. (Bul. Geol. Soc. America, II, 277 292. 1891.) Description of the stratigraphical relations of the various beds in the central part of the State.

Coal Measures (Middle).-See Upper Coal Mcasures. Coal Measures (Upper).

Brachiopods from various localities in Iowa. J. Hall. (Nat. Hist. New York, Pal., VIII, 1-367. 1892.)

Chert of the Upper Coal Measures in Montgomery County. [S. Galvin.] (Am: Geologist, I, 116117. 1888.)

Description of new fossils. C. A. White and O. H. St. John. (Pamphlet, pp. 1-3. Iowa City, 1867.)

Description of new species of fossils. C. A. White and O. H. St. Jọnn. (Trans: Chicago Acad. Sci., I, 115-127. 1867.)

General geological characters in Iowa. C. A: White. Geol. Iowa, I, 241-250. 1870.) The lithological characters described with sections and figures.

Geology of Eastern Nebraska. F. V. Hayden. (U. S. Geol. Sur. of Nebraska, 1-79. 1872.) Incidental remarks on the geology of western Iowa.

In Adair county. C. A. White. (Geol. Iowa, I, 337339. 1870.)

In Cass county. C. A. White. (Geol. Iowa, I, 373375. 1870.) 
Coal Measures (Upper).-Continued.

In Dallas county. O. H. St. John. (Geol. Iowa, II, 13-46. 1870.)

In Guthrie county. O. H. St. John. '(Geol. Iowa, II, 128. 1870.)

In Harrison county. O. H. St: John. (Geol. Iowa, II, 179-181: 1870.)

In Lucas county. O. H. St. John. (Geol. Iowa, II, 93-94. 1870.)

In Madison county. C. A. White. (Geol. Iowa, I, 308-315. 1870.) A rather full account, with sections, of the geology of the county, with special reference to the coal.

In Mills county. C. A. White. (Geol. Iowa, I, 369370. 1870.).

In Montgomery county. C. A. White. (Geol. Iowa, I, 363-366. 1870.)

In Page county. C. A. White. (Geol. Iowa, I, 349352. 1870.).

In Pottawattamie county. C. A. White. (Geol. Iowa, I, 378-380. 1870.)

In Ringgold county. C. A. White: (Geol. Iowa, I, 328. 1870.)

In Taylor county. C. A. White. (Geol. Iowa, I, 345. 1870.)

In Union county. C. A. White. (Geol. Iowa, I, 232234. 1870.)

In Warren county. O. H. St. John. (Geol. Iowa, II, 46-47. 1870.)

New Bryozoans. E. O. Ulrich. (Geol. Sur. Illinois, VIII, 283-688. 1890.)

New species of Paleozoic fossils. S. Calvin. (Bul. Lab. Nat. Hist. State Univ. Iowa, I, 176. 1890.) 
Coal Measures (Upper).-Continued.

Of Decatur county. C. A. White. (Geol. Iowa, I, 320-325. 1870.)

Paleontology of Eastern Nebraska. F. B. Meek. (U.

S. Geol. Surv. of Nebraska, pp. 83-245. 1872.)

Numerous incidental references to the occurrence of fossils in the Upper Coal Measures of Iowa.

Remarks on Prof. Geinitz's Views Respecting the Upper Paleozoic Rocks and Fossils of Southeastern Nebraska. F. B. Meek. (Am. Jour. Sci., (2), XLIV, 170-187. 1867.) Numerous incidental references to the geology of western Iowa.

Rocks of southwestern Iowa shown to be of this age, instead of Lower Carboniferous. C. A.White. (Am. Jour. Sci., (2), XLIV, 23-31. 1867.)

Coelenterates.-See Corals.

Complete Series of Superficial Geological Formations in Northeastern Iowa. W. J. McGee. (Proc. Am. As; Ad. Sci., XXVII, 198-231. 1879.)

Concretionary Limestone.-(Also see St. Louis Limestone.)

In Des Moines county. A. H. Worthen. (Geol. Iowa, I, 201. 1858.)

In Henry county. A. H. Worthen. (Geol. Iowa, I, 215-216. 1858.)

In Jefferson county. A. H. Worthen. (Geol. Iowa, I, 236-237. 1858.)

In Lee county. A. H. Worthen. (Geol. Iowa, I, 190191. 1858.)

In Van Buren county. A. H. Worthen. (Geol. Iowa, I, 226-227. 1858.)

In Wapello county. A. H. Worthen. (Geol. Iowa, I, 254-255. 1858.) 
Cone-in-Cone.

Note on its formation. C. A. White. (Am. Jour. Sci., (2), XLV, 400-401. 1868.)

Contribution to the Fauna of the Lower Coal Measures of Central Iowa. C. R. Keyes. (Proc. Iowa Acad. Sci., 22-23. 1892.)

Contribution to the Geological History of the American Continent. J. Hall. (Proc. Am. As. Ad. Sci., XXXI, pt. i, 29-71. 1883.)

Contribution to Invertebrate Paleontology, No. 8. Fossils from the Carboniferous Rocks of the Interior States. C. A. White. (Twelfth Ann. Rep. U. S. Geol. and Geog. Surv. Terr., 155-171. 1883.)

Contribution to the Knowledge of the Genus Pachyphyllum. C. L. Webster. (Am. Naturalist, XX்III, 621-625. 1889.)

Contribution to the Paleontology of Illinois and other Western States. F. B. Meek and A. H. Worthen. (Proc. Acad. Nat. Sci., Phila., XIX, 251-275. 1868.) Contribution to the Paleontology of Iowa, being descriptions of Crinoidea and other fossils. J. Hall. (Geol. Iowa, I, Supp., 1-92. 1859.)

Copper.

In Iowa drift. C. A. White. (Geol. Iowa, I, 96. 1870.) Occurrence in Iowa. C. A. White, (Geol. Iowa, II, 342. 1870.) The report of native copper ore from the drift.

Corals.

Description of new species. C. A. White and $\mathrm{O}$. $\mathrm{H}$. St. John. (Trans. Chicago Acad. Sci., I, 115-127. 1867.)

Description of new species from Iowa. C. A. White. (Proc. Bost. Soc. Nat. Hist., IX, 8-33. 1865.) 
Corals.-Continued.

Description of new species from Iowa rocks. F. B. Meek and A. H. Worthen. (Geol. Sur. Illinois, II, 143-411. 1866.)

Differences between species of Acervularia. S. Calvin. (Proc. Iowa Acad. Sci., 1890-91, 30-32. 1892.) Fauna of the Lower Coal Measures of Central Iowa. C. R. Keyes. (Proc. Acad. Nat. Sci., Phila., 231-247. 1888.)

From eastern Nebraska. F. B. Meek. (Final Report U. S. Geol. Sur. Nebraska, pt. ii, 83-245. 1872.)

New Genus of Corals from the Devonian. C. L. Webster. (Am. Nat., XXIII, 710-712. 1889.)

New species from Burlington. C. A. White and R. P. Whitfield. (Proc. Boston Soc. Nat. Hist., VIII, 289-316. 1862.)

New species from Burlington. A. Winchell. (Proc. Acad. Nat. Sci., Phila., 225. 1863.)

New species from Iowa. C. A. White. (Rep. Geog. and Geol. Expl. and Surv. W. 100 Merid., IV, 1-219. 1875.)

New species from Iowa. C. A. White. (Twelfth Ann. Rep. U. S. Geol. and Geog. Surv. Terr., 155-171. 1883.)

New species from Paleozoic rocks of Iowa. C. A. White. (Proc. Acad. Nat. Sci., Phila., XXVIII, 27-34. 1877.)

New species from the Devonian. J. Hall and R. P. Whitfield. (New York State Cab. Nat. Hist., 23d Ann. Rep., 223-239. 1873.)

Of central Iowa. C. R. Keyes. (Proc. Acad. Nat. Sci., Phila., 231-247. 1888.)

Pachyphyllum from the Rockford Shales. C. L. Webster. (Am: Naturalist, XXIII, 621-625. 1889.) 
Corals.-Continued.

Spontaneous Fission? in Zaphrentis. C. A. White. (Am. Jour. Sci., (3), V, 72. 1873.)

\section{Corniferous.}

In Scott county. A. S. Tiffany. (Geol. Scott County, etc., 13-19. 1885.)

County Geology. J. D. Whitney. (Geol. Iowa, I, 259323. 1857.) Geological notes on the northeastern counties of Iowa.

\section{Crawford County.}

General description. O. H. St. John. (Geol. Iowa, II, 168-171. 1870.) The general surface features briefly described.

\section{Crinoids.}

Attachment of Platyceras: C. R. Keyes. (Proc. Am. Philos. Soc., XXV, 231-248. 1888.)

Catalogue of the Paleozoic Fossils of North America. B. F. Shumard. (Trans. Acad. Sci., St. Louis, II, 334-407. 1866.)

Classification of Crinoidea. C. R. Keyes. (Am. Naturalist, XXIII, 153, 1889.)

Description of new species. C. A. White. (Boston Jour. Nat. Hist., VII, 481-506. 1863.)

Description of new species. C. A. White and $\mathrm{O}$. $\mathrm{H}$. St. John. (Trans. Chicago Acad. Sci., I, 115-127. 1867.)

Description of new species. J. Hall. (Pamphlet, pp. 1-19. 1861.)

Description of new species. J. Hall. (Bost. Jour. Nat. Hist., VII, 251-328. 1861.)

Description of new species from Iowa. J. Hall. (Geol. Iowa, I, 1-92. 1859.)

Description of new species from Iowa. C. A. White. (Proc. Bost. Soc. Nat. Hist., IX, 8-33. 1865.) 
Crinoids.-Continued.

Description of new species from Iowa. A. H. Worthen. (Illinois State Mus. Nat. Hist., Bul. No. 1, 1-39. 1882.)

Description of new species from Iowa rocks. F. B. Meek and A. H. Worthen. (Geol. Sur. Illinois, II, 143-411. 1866.)

Description of new species from the Iowa Lower Carboniferous. F. B. Meek and A. H. Worthen. (Geol. Sur. Illinois, III, 289-565. 1868.)

Description of new species from the Lower Carboniferous of Iowa. F. B. Meek and A. H. Worthen. (Geol. Sur. Illinois, V, 323-619. 1873.)

Description of New Species of Crinoids. D. D. Owen . and B. F. Shumard. (Rep. Geol. Sur. Wis., Iowa and Minn., App., art: ii, 587-598. 1852.)

Discovery of the Ventral Structure of Taxocrinus and Haplocrinus; and Consequent Modifications in the Classification of the Crinoidea. C. Wachsmuth and F. Springer. (Proc. Acad. Nat. Sci., Phila., 1888, 337-363. 1888.) Recent discoveries at Marshalltown.

From eastern Nebraska. F. B. Meek. (Final Report U. S. Geol. Sur. Nebraska, pt. ii, 83-245. 1872.)

From Lower Carboniferous of Iowa. A. H. Worthen. (Geol. Sur. Illinois, VII, 264-322. 1883.)

Keokuk Species of Agaricocrinus. C. H. Gordon. (Am. Geologist, V, 257-261. 1890.)

Lists of species from Iowa localities. Charles Wachsmuth and Frank Springer. (Proc. Acad. Nat. Sci., Phila., 1879, 226-379. 1879.)

Lists of species from Iowa localities. ' Charles Wachsmuth and Frank Springer. (Proc. Acad. Nat. Sci. , Phila., 1881, 177-414. 1881.) 
Crinoids.-Coniinued.

Lists of species from Iowa localities. Charles Wachsmuth and Frank Springer. (Proc. Acad. Nat. Sci., Phila., 1885, 225-364. 1885.)

Lists of species from Iowa localities. Charles Wachsmuth and Frank Springer. (Proc. Acad. Nat. Sci., Phila., 1886, 64-226. 1886.)

New Fossil Grinoidea from the Paleozoic Rocks of the Western and Southern Portions of the United States. B. F. Shumard. (Trans. Acad. Sci., St. Louis, I, 71-80. 1858.)

New species from Burlington. F. B. Meek and A. H. Worthen. (Proc. Acad. Nat. Sci., Phila., XVII, 143-166. 1865.)

New species from the Burlington limestone. F. B. Meek and A. H. Worthen. (Proc. Acad. Nat. Sci., Phila., XIX, 251-275. 1868.)

New species from the Burlington limestone. F. B. Meek and A. H. Worthen. (Proc. Acad. Nat. Sci., Phila., XXI, 67-83. 1869.)

New species from the Burlington limestone. F. B. Meek and A. H. Worthen. (Proc. Acad. Nat. Sci.,Phila., XIII, 128-148. 1861.)

New species from the Burlington limestone at Burlington. F. B. Meek and A. H. Worthen. (Proc. Acad. Nat. Sci., Phila., XII, 378-397. 1860.)

New species from the Burlington limestone at Burlington. F. B. Meek and A. H. Worthen. (Proc. Acad. Nat. Sci., ,Phila.; XX, 335-859. 1868.)

New species from the Carboniferous of Iowa. F. B. Meek and A. H. Worthen. (Proc. Acad. Nat. Sci., Phila., XII, 447-472. 1860.) 
Crinoids.-Continued.

New species from the Devonian at Davenport. W. H. Barris. (Proc. Davenport Acad. Nat. Sci., II, 282288. 1878.)

New species from the Devonian of Scott county. F. B. Meek and A. H. Worthen. (Proc. Acad. Nat. Sci., Phila., XVII, 138-143. 1865.)

New species from Iowa. A. H. Worthen. (Geol. Surv. Illinois, VIII, 69-154. 1890.)

New species from the Kinderhook of. Marshall county, C. Wachsmuth and F. Springer. (Geol. Surv. Illinois; VIII, 157-251. 1890.)

New species from the Lower Carboniferous rocks of Iowa. A. H. Worthen and F. B. Meek. (Geol. Sur. Illinois, VI, 489-532. 1875.)

New species from the Lower Carboniferous of Marshall county. S. A. Miller and W. F. E. Gurley. (Pamphlet, 59 pp. 1890.)

New species from Paleozoic Rocks of Iowa. C. A. White. (Proc. Acad. Nat. Sci., Phila., XXVIII, 27-34. 1877.)

New species of erinoid from the Burlington limestone.

R. P. Whitfield. (Bul. Am. Mus. Nat. Hist., I, 7-9. 1881.)

New species of Platycrinus and other Fossils from the Mountain Limestone of Illinois and Iowa. A. H. Worthen. (Trans. Acad. Sci., St. Louis, I, 569-571. 1860.)

Observations on the Keokuk Species of Agaricocrinus.

C. H. Gordon. (Proc. Iowa Acad. Șci., 1887-89, 100-101. 1890.)

Occurrence of an Internal Convoluted Plate within the Body of Certain Species of Crinoidea. J. Hall. (Proc. Bost. Soc. Nat. Hist., X, 33-34. 1866.) 
Crinoids.-Continued.

Perisomic Plates of the Crinoids. Charles Wachsmuth and Frank Springer. (Proc. Acad. Nat. Sci.; Phila., 1890, 325-392. 1890.) Incidental references to Iowa species.

Preliminary note on the Sedentary Habits of Platyceras. C. R. Keyes. (Proc. Iowa Acad. Sci.; 1890-1891, 24. 1892.) A preliminary account of the attachment of gasteropods to crinoids.

Stereocrinus, Barris. W. H. Barris. (Proc. Acad. Sci., Davenport, IV, 102-104. 1885.) Described as a new genus.

Structure and Habits of Paleozoic species. F.B. Meek and A. H. Worthen. (Proc. Acad. Nat. Sci., Phila., $\mathrm{XX}, 323-334$. 1868.)

Transition Forms in Crinoids and Description of Five New Species. Charles Wachsmuth and Frank Springer. (Proc. Acad. Nat. Sci., Phila., 224-266. 1878.) A sketch of the evolution of certain crinoids, chiefly from southeastern Iowa.

With Platyceras attached. C. R. Keyes. (Am. Naturalist, XXII, 924. 1888.)

\section{Cretaceous.}

Coal Measures of Central Iowa. C. R. Keyes. (Am. Geologist, II, 395-404: 1888.) Incidental remarks on the eastern extension of the Cretaceous in central Iowa.

Description of new genera and species. C. A. White and O. H. St. John. (Pamphlet, pp. 1-3. Iowa City, 1867.)

Description of the rocks at Sioux City. J. Marcou. (Bul. Soc. Géol. de France, (2), t. XXIV, 56. 1866.) 


\section{Cretaceous.-Continued.}

Description of the rocks in eastern Kansas and Nobraska and their relations to those of adjacent states. F. B. Meek. (Am. Jour. Sci., (2), XXXIX, 157174. 1865.) Numerous incidental references to the geology of western Iowa.

Eastern Extension of the Cretaceous in Iowa. C. R. Keyes. (Proc. Iowa Acad. Sci., 1890-1891, 21. 1892.) Notes on fossils found in the drift and remarks on the eastern limits of the rocks in Iowa.

Fossils in Iowa drift. C. A. White. (Geol. Iowa, I, 98. 1870.)

Fossils in Nishnabotna sandstone. C. A. White. (Geol. Iowa, I, 290. 1870.)

Fossils in the drift. C. A. White. (Proc. Am. As. Ad. Sci., XXI, 187-192. 1873.)

Fossils in the drift of Hardin county. C. A. White. (Am. Geologist, I, 221-227. 1888.)

Fossils in the drift of Linn county. [S. Calvin.] (Am. Geologist, I, 237. 1888.)

In Carroll county. O: H. St. John. (Geol. Iowa, II, 143-144. 1870.)

In Cass county. C. A. White. (Geol. Iowa, I, 373375. 1870.)

In Greene county. O. H. St. John. (Geol. Iowa, II, 133-134. 1870.)

In Guthrie county. C. A. White, (Proc. Am. As. Adv. Sci., XVII, 326-327. 1879.)

In Mills county. C. A. White. (Geol. Iowa, I, 368370. 1870.)

In Montgomery county. C. A. White. (Geol. Iowa, I, 363-366. 1870.) 
Cretaceous.-Continued.

In northwestern Iowa. J. N. Nicollet. (Sen. Doc., 26 Cong., 2nd Sess., V, pt. ii, No.. 237. 1841.) Cretaceous rocks are described above the mouth of the Big Sioux river.

In Woodbury county. O. H. St. John. (Geol. Iowa, II, 192-199. 1870.)

Leaves found in the Nishnabotna sandstone. C. A. White. (Geol. Iowa, I, 292-293. 1870.)

Les Phyllites Crétacees du Nebraska. J. Capellini et O. Heer. (Mém. Soc. Helvétique des Sci. Nat., XXII, 1-24. 1867.)

Occurrence of fossil leaves. C. A. White. (Am. Jour. Sci., (2), XLIV, 119. 1867.)

References to the geology at the mouth of the Big Sioux. F. B. Meek. (U, S. Geol. Sur. Terr., IX, p. xxv. 1876.)

Relation of the Gretaceous Deposits of Iowa to the Subdivisions of the Cretaceous proposed by Meek and Hayden. S. Calvin. (Proc. Iowa Acad. Sci., I, pt. iii, pp. 7-12. 1893.)

\section{Crustacea.}

Description of New Trilobites. D. D. Owen. (Rep. Geol. Sur. Wis., Iowa and Minn., App., art. i, 573577. 1852.)

Description of new species. F. B. Neek and A. H.

Worthen. (Geol. Sur. Illinois, III, 289-565. 1868.)

Description of new species from the Iowa lower Carboniferous. F. B. Meek and A. H. Worthen. (Geol. Sur. Illinois, III, 289-565. 1868.)

From Burlington. A. Winchell. (Proc. Acad. Nat. Sci., Phila., 225. 1863.) 
Crustacea.-Continued.

From eastern Nebraska. F. B. Meek. (Final Report

U. S. Geol. Sur. Nebraska, pt. ii, 83-245. 1872.)

Fossil Faunas in Central Iowa. C. R. Keyes. (Proc. Acad. Nat. Sci., Phila., 242-265. 1891.) Notes and bibliographic references of the species found in the lower Coal Measures of the central part of the State. New Coal Measure species. . C. A. White and O. H. St. John. (Trans. Chicago Acad. Sci., I, 115-127. 1867.)

New Species from the Devonian at Davenport. W. $\mathrm{H}$. Barris. (Proc. Davenport Acad. Nat. Sci., II, 282288. 1878.)

\section{Dallas County:}

Analyses of coal. Rush Emery. (Geol. Iowa, II, 390. 1870.)

General description of the geological features. O. H: St. John. (Geol. Iowa, II, 13-46. 1870.) A full: account of the geology of the county, with numerous sections and illustrations. A number of localities affording fossils mentioned.

Dana, E. S. Catalogue of American Localities of Minerals. (Text-Book of Mineralogy, 15th ed., App. C., Iowa, p. 445. New York, 1889.)

Dana, J. D. Manual of Geology. (3rd ed., pp. 1-911. New York, 1880.) Numerous references to the geology of Iowa.

\section{Davis County.}

- General description. C. A. White. (Geol. Iowa, II, 271. 1870.) Mere mention of the occurrence of the Coal Measures in the county.

Short notes on the geology. C. A. White. (First Ann. Rep. State Geologist, 35-36. 1868.) 19 G. Rep. 
Day, David T. Mineral Resources of the United States; for 1886. (U. S. Geol. Sur., Statistical Papers, 813 pp. Washington, 1887.) Numerous references to Iowa mineral products.

Day, David T. Mineral Resources of the United States, for 1887. (U. S. Geol. Sur., Statistical Papers, 832 pp. Washington, 1888.) Numerous references to Iowa mineral products.

Day, David T. Mineral Resources of the United States, for 1888. (U. S. Geol. Sur., Statistical Papers, 652 p.p. Washington, 1890.) Numerous allusions to Iowa minerals.

Day, David T. Mineral Resources of the United States, for 1889 and 1891. (U. S. Geol. Sur., Statistical Papers, 671 pp. Washington, 1892.) References to the mineral resources of the State.

Day, William C. Stones. (Report of the Mining Industry of the United States at the 11th Census in 1890, pp. 593-666. Washington, 1892.) Brief references to the building stones of Iowa.

\section{Decatur County.}

General geology described. C., A. White. (Geol. Iowa, I, 318-327. 1870.) A consideration of the surface characters and geology of the county, with a number of sections and a detailed description.

Short notes on the geology. C. A. White. (First Ann. Rep. State Geologist, 42-43. 1868.).

\section{Delaware County.}

Notes on the geology. J. D. Whitney. (Geol. Iowar I, 295-296. 1858.)

Superposition of Glacial Drift upon Residuary Clays. W. J. MoGee. (Am. Jour. Sci., (3), XVIII, 301303. 1879.) 
Description of a Deep Well at Emmettsburg, Iowa. N. H. Winchell. (Bul. Mimnesota Acad. Sci., I, 387-390. 1880.)

Description of a New Genus of Corals from the Devonian Rocks of Iowa. C. L. Webster. (Am. Naturalist, XXIII, 710-712. 1889.)

Description of a New Species of Crinoid from the Burlington Limestone, at Burlington, Iowa. R. P. Whitfield. (Bul. Am. Mus. Nat. Hist., vol. I, pp. 7-9. 1891.)

Description of Fossils from the "Yellow" Sandstone lying below the Burlington Limestone, at Burlington, Iowa. A. Winchell. (Proc. Acad. Nat. Sci., Phila., 2-25. 1863.)

Description of Fossil Fishes. O. H. St. John and A. H. Worthen. (Geol. Sur. Illinois, VI, 245-288. 1875.)

Description of Fossil Fishes. Orestes St. John and A. H.Worthen. (Geol. Sur. Illinois, VII, 53-264. 1883.) Description of Fossil Invertebrates. A. H. Worthen. (Geol. Sur. Illinois, VI, 264-322. 1883.)

Description of Fossil Invertebrates. A. H. Worthen. (Geol. Sur. Illinois, VIII, 69-154. 1890.)

Description of Invertebrates. A. H. Worthen and F. B. Meek. (Geol. Sur. Illinois, VI, 489-532. 1875.)

Description of Invertebrates from the Carboniferous System. F. B. Meek and A. H. Worthen. (Geol. Sur. Illinois, V, 323-619. 1873.)

Description of One New Genus and Twenty-two New Species of Crinoids from the Subcarboniferous Limestone of Iowa. B. F. Shumard and D. D. Owen. (Rep. Geol. Sur.Wis., Iowa and Minn., 587-598. 1852.) Description of Polyzoa from Paleozoic Rocks. A. H. Prout. (Geol. Sur. Illinois, II, 412-424. 1886.) 
Description of New and Imperfectly Known Genera and - Species of Organic Remains Collected during the Geological Surveys of Wisconsin, Iowa and Minnesota. D. D. Owen. (Geol. Sur. Wis., Iowa and Minn., 573587. 1852.)

Description of Some New Blastoids from the Hamilton Group. W. H. Barris. (Geol. Sur. Illinois, VII, 357-364. 1883.)

Description of New Carboniferous Fossils from Illinois and other Western States. F. B. Meek and A. H. Worthen. (Proc. Acad. Nat. Sci., Phila., XII, 447472. 1860.)

Description of New Crinoidea and Echinoidea from the Carboniferous Rocks of the Western States; with a note on the Genus Onychaster. F. B. Meek and A. H. Worthen. (Proc. Acad. Nat. Sci., Phila., XXI, 6783. 1869.)

Description of New Crinoids and Blastoids from the Hamilton Group. W. H. Barris. (Proc. Davenport Acad. Sci., IV, 88-94. 1885.)

Description of New Fossil Crinoidea from the Paleozoic Rocks of the Western and Southèrn Portions of the United States. B. F. Shumard. (Trans. Acad. Sci., St. Louis, I, 71-80. 1858.)

Description of New Paleozoic Fossils from Illinois and Iowa. F. B. Meek and A. H.Worthen. (Proc. Acad. Nat. Sci., Phila., XIII, 128-148. 1861.)

Description of New Species and Genera of Fossils from the Paleozoic Rocks of the Western States. F. B. Meek and A. H. Worthen. (Proc. Acad. Nat. Sci., Phila., XXII, 22-56. 1870.)

Description of New Species of Blastoidea from the Paleozoic Rocks of the Western States, with some Observa- 
Description, etc.-Continued.

tions on the Structure of the Summit of the Genus Pentremites. B. F. Shumard. (Trans. Acad. Sci., St. Louis, I, 238-248. 1868.)

Description of New Species of Crinoidea. J. Hall. (Pamphlet, 1-19. 1861.)

Description of New Species of Crinoidæ, etc., from the Paleozoic Rocks of Illinois and some of the Adjoining States. F. B. Meek and A. H.Worthen. (Proc. Acad. Nat. Sci., Phila., XVII, 143-166. 1865.)

Description of New Species of Crinoidea from the Carboniferous Rocks of the Mississippi Valley. J. Hall. (Bost. Jour. Nat. Hist., VII, 251-328. 1861.)

Description of New Species of Crinoids. A. H.Worthen. (Illinois State Mus. Nat. Hist., Bul. No. 1, 1-39. 1882.)

Description of New Species of Fossils from the Devonian Rocks of Iowa. J. Hall and R. P. Whitfield. (New York State Cab. Nat. Hist., 23d Ann. Rep., 223-239. 1873.)

Description of New Species of Fossils from the Devonian and Carboniferous Rocks of the Mississippi Valley. C. A. White. (Proc. Boston Soc. Nat. Hist., IX, 8-33. 1865.)

Description of New Species of Fossils from the Hamilton Group of Western New York, with Notices of others from the same Horizon in Iowa and Indiana. J. Hall. (New York State Cab. Nat. Hist., 13th Ann. Rep., App. F, 76-94. 1860.)

Description of New Species of Fossils from the Marshall Group of Michigan and its supposed Equivalent in other States; with Notes on some Fossils of the same Age previously Described. A. Winchell. (Proc. Acad. Nat. Sci., Phila., XVII, 109-133. 1865.) 
Description of New Species of Fossils from the Paleozoic

- Rocks of Iowa. C. A.White. (Proc. Acad. Nat. Sci., Phila., XXVIII, 27-34. 1877.)

Description of New Species of Spirifera from the Hamilton Group near Iowa City, Iowa. S. Calvin. (Bul. Lab. Nat. Hist. State Univ. Iowa, I, 28-29. 1888.)

Description of New Subcarboniferous and Coal Measure Fossils, Collected upon the Geological Survey of Iowa, together with Notice of New Generic Characters Observed in two Species of Brachiopods. C. A. White and O. H. St. John. (Trans. Chicago Acad. Sci., I, 115-127. 1867.)

Description of New Invertebrates from the Carboniferous System. F. B. Meek and A. H. Worthen. (Geol. Sur. Illinois, II, 143-411. 1866.)

Description of New Species of Vertebrates. J. S. Newberry and A. H. Worthen. (Geol. Sur. Illinois, II, 9-134. 1866.)

Description of Some New Genera and Species of Echinodermata from the Coal Measures and Subcarboniferous Rocks of Indiana, Missouri and Iowa. S. A. Miller and W. F. E. Gurley. (Pamphlet, 59 pp., 10 plates. 1890.)

Description of Two New Fossils from the Devonian of Iowa. C. R. Keyes. (Proc. Acad. Nat. Sci., Phila., 247-248. 1888.)

Description of the Quarries and Quarry Regions of Iowa. W. J. McGee. (Tenth Census of U. S., X, 256-265. 1883.)

Description of the Rockford Shales of Iowa. C. L. Webster. (Proc. Davenport Acad. Sci.,V, 100-109. 1887.) Description of Vertebrates. J. S. Newberry and A. H. Worthen. (Geol. Sur. Illinois, IV, 346-374. 1870.) 
Description of New Species of Crinoidea and Echinodea from the Carboniferous Rocks of Illinois and other Western States. F. B. Meek and A. H. Worthen. (Proc. Acad. Nat. Sci., Phila., XII, 378-397. 1860.)

\section{Des Moines County.}

Attachment of Platyceras to Palæocrinoids. C. R. Keyes. (Am. Naturalist, XXII, 924. 1888.)

Brief notes on the geology. C. A. White. (First Ann. Rep. State Geologist, 30-35. 1868.)

Certain Forms of Straparollus from Southeastern Iowa.

C. R. Keyes. (Am. Geologist, V, 193-197. 1890.) Classification of the Lower Carboniferous Rocks of the Mississippi Valley. G. R. Keyes. (Washington: Judd and Detweiller, printers, 1-24. 1892.) Sections and details of the rocks in southeastern Iowa.

Description of new species of crinoids from Burlington. F. B. Meek and A. H. Worthen. (Proc. Acad. Nat. Sci., Phila., XXI, 67-73. 1868.)

Description of new species of echinoderms. F. B. Meek and A. H. Worthen. (Pŗoc. Acad. Nat. Sci., Phila., XIX, 251-275. 1868.)

Epsomite. G. A. White. (Geol. Iowa, II, 305-306. 1870.)

Evidence of Two Distinct Geological Formations in the Burlington Limestone. W. H. Niles and Charles Wachsmuth. (Am. Jour. Sci., (2), XLII, 95-99. . 1866.) A sketch of the Burlington beds and a list of crinoids found in the upper and lower divisions.

Fish remains in the Carboniferous limestone. A. H. Worthen. (Proc. Am. As. Ad. Sci., X, 189-192. 1856.)

Fossils from the "yellow" sandstone found at Bur- 
Des Moines County.-Continued. lington. A. Winchell. (Proc. Acad. Nat. Sci., Phila., XV, 225. 1863.)

Gasteropods from Burlington, Iowa. C. R. Kéyes. (Proc. Acad. Nat. Sci., Phila., 283-298. 1889.)

General account of the geological formations. A. H. Worthen. (Geol. Iowa, I, 198-208. 1858.) A brief detailed account of the geology of the county. Geology and Paleontology of Burlington. C. A. White. (Boston Jour. Nat. Hist., VII, 209-235. 1860.)

List of fossils found in the Burlington bluff. J. N. Nicollet. (Sen. Doc., 26 Cong., 2nd Sess., V, pt. ii, No. 237. 1841.)

Marshall Group: A Memoir on its Geological Position, Characters and Equivalencies in the United States. A. Winchell. (Proc. Am. Phil. Soc., XI, 57-83. 1869.)

New crinoids from Burlington. F. B. Meek and A. H. Worthen. (Proc. Acad. Nat. Sci., Phila., XII, 447-472. 18660.)

New crinoids from Burlington. F. B. Meek and A. H. Worthen. (Proc. Acad. Nat. Sci., Phila., XX, 335-359. 1868.)

New fossils from Iowa. F. B. Meek and A. H. Worthen. (Proc. Acad. Nat. Sci., Phila., XIII, 128148. 1861.)

New species of blastoids from Burlington. . F. B. Meek and A. H. Worthen. (Proc. Acad. Nat. Sci. Phila., XXI, 83-91. 1869.)

New species of blastoids from Burlington. F. B. Meek and A. H. Worthen. (Proc. Acad. Nat. Sci., Phila., XXII, 22-56. 1870.)

New species of brachiopods from Burlington. A. 
:

Des Moines County.-Continued.

Winchell. (Proc. Acad. Nat, Sci., Phila., XVII, 109-133. 1865.)

New species of crinoid from Burlington limestone. R. P. Whitfield. (Bul. Am. Mus. Nat. Hist., I, 7-9. 1881.)

New species of crinoids from Burlington. F. B. Meek and A. H. Worthen. (Proc. Acad. Nat. Sci., Phila., XVII, 143-166. 1865.)

New species of crinoids from Burlington. C. A. White. Boston Jour. Nat. Hist., VII, 481-506. 1863.)

New species of echinoderms described from Burlington. F. B. Meek and A. H. Worthen. (Proc. Acad. Nat. Sci., Phila., XII, 378-397. 1860.)

New Species of Platycrinus and other Fossils from the Mountain Limestones of Illinois and Iowa. A. H. Worthen. (Trans. Acad. Sci., St. Louis, I, 569571. 1860.)

Observations on rocks and description of new species of fossils from Burlington, Iowa. C. A. White and R. P. Whitfield. (Proc. Boston Soc. Nat. Hist., VIII, 289-316. 1862.).

Principal Mississippian Section. C. R. Keyes. (Bul. Geol. Soc. America, III, 283-300. 1892.) Sections and details of the lower Carboniferous rocks described.

Surface Geology of Burlington. C. R. Keyes. (Am. Naturalist, XXII, 1049-1054. 1888.)

Transition Forms in Crinoids and Description of Five New Species. Charles Wachsmuth and Frank Springer. (Proc. Acad. Nat. Sci., Phila., 224-266. 1878.) A sketch of the evolution of certain crinoids, chiefly from southeastern Iowa. 
Devonian.

Brachiopods from various localities in Iowa. J. Hall. (Nat. Hist. New York, Pal., VIII, 1-367. 1892.)

Correlation of the rocks in Iowa. H. S. Williams. (Bul. 80, U. S. Geol. Sur., 1-279. 1891.) Numerous references.

Dark Shales at Independence, Iowa. S. Calvin. (Bulletin U. S. Geol. and Geog. Sur. Terr., vol. IV, pp. 735-738.) Short account of geology and fossils with descriptions of five new species.

Description of New Blastoids. W. H. Barris. (Geol. Sur. Illinois, VII, 357-364. 1883.)

Description of the New Crinoids and Blastoids from the Hamilton Group. W. H. Barris. (Proc. Davenport Acad. Sci.; IV; 88-94. 1885.) Description of the new species Elæacrinus obovatus from Iowa.

Description of new fossils. Jamés Hall. (Geol. Iowa, I, 476-516. 1858.)

Description of new species of brachiopods. D. D. Owen. (Rep. Geol. Sur. Wis., Iowa and Minn., App., art. i; 583-586. 1852.).

Description of new species of fossils. "J. Hall. (New York State Cab. Nat. Hist., 13th Ann. Rep., App. F; 76-94. 1860.) .

Description of new species of fossils. F. B. Meek and A. H. Worthen. (Geol. Sur. Illinois; III, 289565. 1868.)

Description of new species of fossils. C: A. White. (Proc. Bost. Soc. Nat. Hist., IX, 8-33. 1865.)

Description of a New Species of Spirifera from the Hamilton Group near Iowa City, Iowa. S. Galvin. (Bul. Lab. Nat. Hist: State Univ. Iowa, I, 28-29. 1888.) 


\section{Devonian.-Continued.}

Description of the geological features along the Cedar and Iowa rivers in eastern Iowa. D. D. Owen. (Rep. Geol. Sur. Wis., Iowa and Minn., 77-90. 1852.)

Devonian and Carboniferous : Correlation Papers. H.

S. Williams. (Bul. 80, U. S. Geol. Sur., 1-279. 1891.) Numerous references.

Differenees between Acervularia, at Independence and elsewhere. S. Calvin. (Am. Geologist, IX, 255258. 1892.) Brief remarks.

Differences between Acervularia, at Independence and elsewhere. S. Galvin. (Proc. Iowa Acad. Sci., 1890-1891, 30-32. 1892.) Brief remarks.

Distribution - of - Rockford Shales. C. L. Webster. (Proc. Davenport Acad. Nat. Sci., V, 100-109. 1887.)

Equivalency of Lime Creek beds. H. S. Williams. (Am. Jour: Sei., (3), XXV, 311. 1883.)

Fauna at Lime Creek, Iowa. S. Calvin. (Am. Jour. Sci., (3), XXV, 434-436. 1883.) Remarks on the fossils with description of a new species.

General geological description. C. A. White. (Geol. Iowa, I, 184-188. 1870.) The' general characters economic value and geological age of various beds briefly described.

In Buchanan county. S. Calvin. (Am. Geologist, VIII, 142-145. 1891.)

In Scott county. A. S. Tiffany. (Geol. Scott County, etc., 1-30. 1885.)

General Preliminary Description of the Devonian Rocks of Iowa, which constitutes a Typical Section of the Devonian Formation of the Interior Contin- 
Devonian.-Continued.

ental area of North America. C. L. Webster. (Am. Naturalist, XXIII, 229-243. 1889.)

New Bryozoans. E. O. Ulrich. (Geol. Sur. Illinois, VIII, 283-688. 1890.)

New Conocardium from the Iowa Devonian. C. R.

Keyes. (Proc. Iowa Acad. Sci., 1890-1891, 23-24.

1892.) Description of the Conocardium altum, regarded as new.

New erinoids from Buffalo. A. H. Worthen. (Geol.

Surv. Illinois, VIII, 69-154. 1890.)

New crinoids from Scott county. F. B. Meek and A. H. Worthen. (Proc. Acad. Nat. Sci.,Phila., XVII, 138-143. 1865.)

-New fossils from Davenport. W. H. Barris. (Proc. Davenport Acad. Nat. Sci.; II, 282-288. 1878.)

New Genus of Corals. C. L. Webster. (Am. Naturalist, XXIII, 710-712. 1889.)

New species of Annelid. S. Calvin. (Am. Geologist, I, 24-28. 1888.)

New species of Blastoidea from the Paleozoic rocks of

Western States. B. F. Shumard. (Trans. Acad. Sci., St. Louis, I, 238-248. 1858.)

New species of Fossils. J. Hall and R. P. Whitfield. (New York State Gab. Nat. Hist., 23d Ann. Rep., 223-239. 1873.)

New Species of Fossils. C. A. White. (Proc. Acad. Nat. Sci., Phila., XXVIII, 27-34. 1877.)

New Species of Palæozoic Fossils. S. Calvin. (Bul. Lab. Nat. Hist. State Univ. Iowa, I, 174. 1890.)

New Species of Palrozoic Fossils. S. Calvin. (Bul. Lab. Nat. Hist. State Univ. Iowa, I, 178-179. 1890.) Northeastern Iowa. W. J. McGee. (Eleventh Ann. Rep. U. S. Geol. Surv., 314-323. 1892.) 
Devonian.-Continued.

Notes on the Rockford Shales. C. L. Webster. (Am. Naturalist, XXII, 444-446. 1888.)

Notes on the Synonyny, Characters and Distribution of Spirifera parryana Hall. S. Calvin. (Bul. Lab. Nat. Hist. State Univ. Iowa, I, 18-28. 1888.)

Paleontology of New York. J. Hall. (Nat. Hist. New York, Paleontology, IV, 422 pp. 1867.) A number of references to fossils occurring in Iowa. Preliminary Notice of Newberria. J. Hall. (Tenth Ann: Rep. State Geologist of New York, 91-102. 1891.) Species from Iowa noted.

Remarkable Fauna at the base of the Chemung in New York. H. S. Williams. (Am. Jour. Sci., (3), XXV, 97-104. 1883:) A number of comparisons of fossils of the Lime creek beds of Iowa with those of New York.

Relation of the faunas of Iowa. H. S. Williams. (Am. Geologist, III, 230-233. 1889.)

Sandstones in Muscatine county. S. Calvin. (Am. Geologist, III, 25-36. 1889.)

Some Geological Problems of Muscatine County. S. Calvin. (Bul. Lab. Nat. Hist. State Univ. Iowa, I, 7-18. 1888.) Certain rocks in the county shown to be Devonian instead of Kinderhook, as was formerly supposed by Hall.

Stereocrinus, Barris. W. H. Barris. (Proc. Acad. Sci., Davenport, IV, 102-194. 1885.) Described as a new genus.

Synonony of Two Species of Spirifera. S. A. Miller. (Proc. Davenport Acad. Sci., II, 220-221. 1878.) Two new fossils. C. R. Keyes. (Proc. Acad. Nat. Sci., Philadelphia, pp. 247-248. 1888.) Two species described as new. 
Dickerson County.

Geneial description. C. A. White. (Geol. Iowá, II, 21 $\dot{9}-223$. 1870.) Its surface features briefly, described.

Dickinson, W. H. Water Supplies: Its relation to Health and Disease. (Iowa State Board of Health, First Biennial Report, pp. 197-227. Des Moines, 1882.) Remarks on the waters of Iowa, with several chemical analyses given.

Dictionary of the fossils of Pennsylvania. J. P. Lesley. (Geol. Sur. Pennsylvania, Rep. P4, vols. I-III, 1-1283. 1890.)

Discovery of the Ventral Structure of Taxocrinus and Haplocrinus; and Consequent Modifications of the Classification of the Crinoidea. C. Wachsmuth and F. Springer. (Proc. Acad. Nat. Sci., Phila., 337-363. 1888.)

Distribution of Certain Loess Fossils. C. R. Keyes. (Am. Geologist, VI, 119. 1890.)

\section{Drainage.}

Drainage System and Distribution of the Loess of Eastern Iowa. W. J. McGee: (Pamphlet, pp. 1-14. Ft. Dodge, 1884.)

Drainage System and the Distribution of the Loess of. Eastern Iowa. W. J. McGee. (Bul. Philosophical Soc. Washington, VI, 93-97. 1883.)

General drainage features. C. A. White. (Geol. Iowa, I, 35-70. 1870.) General course and characters of the rivers with estimates of average fall of the principal streams. Also special description of the different water courses.

Of Northeastern Iowa. W. J. McGee. (Eleventh Ann. Rep. U. S. Geol. Sur., 358-363. : 1892.) 


\section{Ḋrift.}

Artesian Wells in Iowa. R. E. Call. '(Proc. Iowa Acad. Sci., 1890-1891, 57-63. 1892.) Description of wells in the drift.

At Burlington, Iowa. C. R. Keyes. (Am. Naturalist, XXII. 1049-1054. 1888.)

At Keokuk, Iowa. C. H. Gordon. (Report Dep. Nat. Hist. Northwestern Univ., 11-19. 1891.)

Beds of Carboniferous Drift in the Bluffs of East Davenport. Tyler MeWhorther. (Proc. Davenport Acad. Nat. Sci., III, 129-130. 1882.)

Bones of the Mammoth in Washington County, Iowa. J. Gass and W. H. Pratt. (Proc. Davenport Acad. Nat. Sci., III, 177-178. 1882.)

Complete Series of Superficial Geological Formations in Northeastern Iowa. W. J. McGee. (Proc. Am. As. Ad. Sci., XXVII, 198-231. 1878.)

Cretaceous fossils in the drift. [S. Calvin.] (Am: Geologist, I, 237. 1888.)

Cretaceous fossils in the drift. C. A. White. (Proc. Am. As. Adv. Sci., XXI, 187-192. 1873.)

Cretaceous fossils in the drift of Hardin county. C. A. White. (Am. Geologist, I, 221-227. 1888.)

Description of the deposits near Davenport. W. H. Pratt. (Proc. Davenport Acad. Nat. Sci., I, 96-99. 1876.)

Driftless area of the upper Mississippi. T. C. Chamberlin and R. D. Salisbury. (U. S. Geol. Sur., 6th Ann. Rep., 199-322. 1886.)

Drift Phenomena of Southwestern Iowa. C. A. White. (Am. Jour. Sci., (2), XLIV, 119. 1867.) Eastern Extension of the Cretaceous in Iowa. C. R. Keyes. (Proc. Iowa Acad. Sci., 1890-91, 21. 1892.). 
Drift.-Continued.

Cretaceous fossils found in the drift at Des Moines. General description. C. A. White. (Geol. Iowa, I, 82-102. 1870.) A general account of the physical composition and properties of the drift, as found in Iowa; together with its distribution. Its origin, glacial phenomena and foreign substances found in it,described: Altered drift briefly referred to.

History of the Drift Deposits of Iowa. J. E. Todd. (Proc. Iowa Hort. Soc., XVIII, 316-327. 1883.)

In Des Moines county. A. H.Worthen. (Geol. Iowa, I, 200. 1858.)

In Henry county. A. H. Worthen. (Geol. Iowa, I, 210-211. 1858.)

In Lee county. A. H. Worthen. (Geol. Iowa, I, 187-188: 1858.)

In Madison county. C. A. White. (Geol. Iowa, I, 305-308. 1870.)

In southwestern Iowa. C. A. White. (Am. Jour. Sci., (2), XLIV, 119. 1867.) Additional note to an article of the same title.

In Van Buren county. A. H. Worthen. (Geol. Iowa, I, 221. 1858.)

Iowa Drift. C. A. White. (Am. Naturalist, II, 615616. 1869.) Calls attention to the original site of the granite boulders found in Iowa.

Its derivation. C. A. White. (Am. Naturalist, II, 615-616. 1869.)

Notes on the geology of a part of the Mississippi-Valley. W. J. McGee. (Geological Magazine, (2), VI, 412-420 and 353-362. 1879.)

Observations upon the Drift Phenomena. C. A. White. (Second Ann. Rep. State Geologist, 143148. 1868.) 
Drift.-Continued.

Observations upon the Drift Phenomena of Southwestern Iowa. C. A. White. (Am. Jour. Sci., (2), XLIII, 301-305. 1867.)

Of northeastern Iowa. W.J. MeGee. (Eleventh Ann. Rep. U. S. Geol. Sur., 472-543. 1892.)

Ovibos cavifrons from the Loess at Council Bluffs.

W. J. McGee. (Am. Jour. Sci., (3), XXXIV, 217220. 1887.)

Quarternary Section Eight Miles Southeast of Des Moines, Iowa. C. R. Keyes and R. E. Call. (Proc. Iowa Acad. Sci., 1890-1891, 30. 1892.) Description of a section near the terminal moraine near Des Moines.

Quartzite boulders in western Iowa. C. A. White. (Proc. Am. As. Adv. Sci., XVII, 340-342. 1869.) Relation of Loess to Drift in Southwestern Iowa. J. E. Todd. (Proc. Iowa Acad. Sci., 1875-1880, 19. 1880.) Relative Position of Forest Beds and Associated Drift Formations in Northeastern Iowa. W. J. McGee. (Am. Jour. Sci., (3), XV, 339-341. 1878.)

Superposition of Glacial Drift upon Residuary Clays. W. J. MeGee. (Am. Jour. Sci., (3), XVIII, 301303. 1879.)

Section of the Bluff at Sixth Street, Davenport. W. H. Pratt. (Proc. Davenport Acad. Nat. Sci., III, 127129. 1881.)

Surface geology of Keokuk. C. H. Gordon. (Am. Geologist, IX, 183-190. 1892.)

Surface geology of the Raccoon river region. O. $H$. St. John. (Second Ann. Rep. State Geologist, 173190. 1868.) 
Drift.-Continued.

Terminal moraine of the second glacial epoch. T. C. Chamberlain. (U. S. Geol. Sur., Third Ann. Rep., 291-404. 1883.)

Transitional Drift of a Portion of Northern Iowa. C.

L. Webster. (Am. Naturalist, XXIV, 1182-1185. 1890.)

Dubuque County.

General description. J. D. Whitney. Geol. Iowa, I, 286-295. 1858.) A short detailed account of the geology of the courtty.

Notes on lead mines. C. A. White. (Second Ann. Rep. State Geologist, 97-100. 1868.)

Pyrite crystals described. C. R. Keyes. (Proc. Iowa Acad. Sei., I, pt. iii, 19-22. 1893.)

Relative Position of Forest Beds and Associated Drift Formations of Northeastern Iowa. W. J. McGee. (Am. Jour. Sci., (3), XV, 339-341. 1878.)

Section of the Maquoketa Shales in Iowa. J. F. James. (Proc. Am. As. Ad. Sci., XXXVII, 250251. 1890.

Driftless Area of the Upper Mississippi. T. C. Chamberlin and R. D. Salisbury. (U. S. Geol. Sur., 6th Ann. Rep., 199-322. 1886.)

Dutton, Clarence Edward. Charleston Earthquake of August 31, 1886. (U. S. Geol. Sur., 9th Ann. Rep., pp. 205-528. Washington, 1889.) Notes on the shock felt in several parts of Iowa are given on pages 443 and 446.

Eaton; E. N. Winnebago Meteorite. (Am. Geologist, vol. VIII, pp. 385-387. Minneapolis, 1891.) Table of analyses of a meteorite which fell in Winnebago county. 
Eastern Extension of the Cretaceous in Iowa. C. R. Keyes. (Proc. Iowa Acad. Sci., vol. I, pt. iii, 21. 1892.) Echinoderms.

Carboniferous species of the Mississippi basin. C. R. Keyes. (Am. Jour. Sci., (3), XXXIII, 186-193. 1889.)

Catalogue of the Paleozoic Fossils of North America. B. F. Shumard. (Trans. Acad. Sci., St. Louis, II, 334-407. 1866.)

Classification of Crinoidea. , G. R. Keyes. (Am. Naturalist, XXIII, 153. $18 \dot{89}$.

Description of new species from Iowa rocks. F. B. Meek and A. H. Worthen. (Geol. Sur. Illinois, II, 143-411. 1866.)

Description of new species from the Hamilton group. W. H. Barris. (Geol. Sur. Illinois, VII, 357-364. 1883.)

Description of new species from the Iowa Lower Carboniferous. F. B. Meek and A. H. Worthen. (Geol. Sur. Illinois, III, 289-565. 1868.)

Description of new species from the Lower Carboniferous of Iowa. F. B. Meek and A. H. Worthen. (Geol. Sur. Illinois, V, 323-619. 1873.)

Description of the New. Crinoids and Blastoids from the Hamilton Group. W. H. Barris. (Proc. Davenport Acad. Sci., IV, 88-94. 1885.) Description of the new species Elacacrinus obovatus from Iowa.

Discovery of the Ventral Structure of Taxocrinus and Haplocrinus; and Consequent Modifications in the Classification of the Crinoidea. C. Wachsmuth and F. Springer. (Proc. Acad. Nat. Sci., Phila., 1888, 337-363. 1888.) Recent discoveries at Marshalltown noted. 
Echinoderms.-Continued.

Fauna of the Lower Coal Measures of Central Iowa. C. R. Keyes. (Proc. Acad. Nat. Sci., Phila., 231247. 1888.)

Fossil Faunas in Central Iowa. C. R. Keyes. (Proc. Acad. Nat. Sci., Phila., 242-265. 1891.) Notes and bibliographic references of the species found in the lower Coal Measures in the central part of the State.

List of species from Iowa localities. Charles Wachsmuth and Frank Springer. (Proc. Acad. Nat. Sci., Phila., 226-379. 1879.)

List of species from Iowa localities. Charles Wachsmuth and Frank Springer. (Proc. Acad. Nat. Sci., Phila., 1881, 177-414. 1881.)

List of species from Iowa localities. Charles Wachsmuth and Frank Springer. (Proc. Acad. Nat. Sci., Phila., 1885,'225-364. 1885.)

List of species from Iowa localities. Charles Wachsmuth and Frank Springer. (Proc. Acad. Nat. Sci., Phila., 1886, 64-226. 1886.)

New Fossil Crinoidea from the Paleozoic Rocks of the Western and Southern Portions of the United States. B. F. Shumard. ('Trans. Acad. Sei., St. Louis, I, 71-80. 1858.)

New species from Burlington. F. B. Meek and A. H. Worthen. (Proc. Acad. Nat. Sci., Phila., XVII, 143-156. 1865.)

New species from Burlington. F. B. Meek and A. H. Worthen. (Proc. Acad. Nat. Sci., Phila., XXI, 8391. 1869.)

New species from the Burlington limestone. F. B. Meek and A. H. Worthen. (Proc. Acad. Nat. Sci., Phila., XIX, 251-275. 1868.) 


\section{Echinoderms.-Continucd.}

New species from the Burlington limestone at Burlington. F. B. Meek and A. H. Wrorthen. (Proc. Acad. Nat. Sci., Phila., XXII, 22-56. 1870.)

New species from the Burlington limestone at Burlington. F. B. Meek and A. H. Worthen. (Proc. Acad. Nat. Sci., Phila., XII, 378-397. 1860.)

New species from the Burlington limestone at Burlington. F. B. Meek and A. H. Worthen. (Proc. Acad. Nat. Sci., Phila., XX, 335-359. 1868.)

New species from the Burlington limestone of Iowa. F. B. Meek and A. H. Worthen. (Proc. Acad. Nat. Sci., Phila., XIII, 128-148. 1861.)

New species from the Carboniferous of Iowa. F. B. Meek and A. H. Worthen. (Proc. Acad. Nat. Sci., Phila., XII, 447-472. 1860.)

New species from the Devonian at Davenport. W. H. Barris. (Proc. Davenport Acad. Nat. Sci., II, 282288. 1878.)

New species from the Devonian of Scott county. F. B. Meek and A. H. Worthen. (Proc. Acad. Nat. Sci., Phila., XVII, 138-143. 1865.)

New species from the Lower Carboniferous of Marshall county. S. A. Miller and W. F. E. Gurley. (Pamphlet, 59 pp. 1890.)

New species from the Lower Carboniferous rocks of Iowa. A. H. Worthen and F. B. Meek. (Geol. Sur. Illinois, VI, 489-532. 1875.)

New species from Paleozoic Rocks of Iowa. C. A. White. (Proc. Acad. Nat. Sci., Phila., XXVIII, 27-34. 1877.)

$\mathrm{N}$ ew species of Blastoidea from the Paleozoic rocks of the Western States. B. F. Shumard. (Trans. Acad. Scr., St. Louis, I, 238-248. 1858.) 
Echinoderms.-Continued.

New species of crinoid from the Burlington limestone. R. P. Whitfield. (Bul. Am. Mus. Nat. Hist., I, 7-9. 1881.

New species of Platycrinus and other Fossils from the Mountain Limestone of Illinois and Iowa. A. H. Worthen. (Trans. Acad. Sci., St. Louis, I, 569-571. 1860.)

Of central Iowa. C. R. Keyes. (Proc. Acad. Nat. Sci., Phila., 231-247. 1888.)

Perisomic Plates of the Crinoids. Charles Wachsmuth and Frank Springer. (Proc. Acad. Nat. Sci., Phila., 1890, 325-392. 1890.) Incidental references to Iowa species.

Platyceras attached to crinoids. C. R. Keyes. (Proc. Am. Philosophical Soc., XXV, 231-248. 1888.)

Preliminary Note on the Sedentary Habits of Platyceras. C. R. Keyes. (Proc. Iowa Acad. Sci., 1890-1891, 24. 1892.) A preliminary account of the attachment of gasteropods to crinoids.

Stereocrinus, Barris. W. H. Barris. (Proc: Davenport Acad. Sci.; IV, 102-104. 1885.) Described as a new genus.

Transition Forms in Crinoids and Description of Five New Species. Charles Wachsmuth and Frank Springer." (Proc. Acad. Nat. Sci., Phila., 224-266. 1878.) A sketch of the evolution of certain crinoids, chiefly from southeastern Iowa.

Echinoids.

Description of new species from the Lower Carboniferious of Iowa. F. B. Meek and A. H. Worthen. (Geol. Sur. Illinois, V, 323-619. 1873:)

New species from the Burlington: F. B. Meek and 
Echinoids.-Continued.

A. H. Worthen. (Proc. Acad. Nat. Sci., XXI, 6783. 1869.)

New species from the Burlington limestone of Burlington. F. B. Meek and A. H. Worthen. (Proc. Acad. Nat. Sci., Phila., XII, 378-397. 1860.)

New species from the Lower Carboniferous of Marshall county. S. A. Miller and W. F. E. Gurley. (Pamphlet, 59 pp.' 1890.)

\section{Elevations.}

Principal points in the State. C. A. White. (Geol. Iowa, I, 30. 1870.) A tabular statement of the elevation of some of the chief places in the State.

Emery, Rush. Chemical Report of the Geological Survey of Iowa. (Geol. Iowa, vol. II, pp. 343-402. Des Moines, 1870.) Results of analyses, and descriptions of the various rocks, clays, waters, coals and peats.

\section{Emmet County.}

General geological description. C. A.White. (Geol. Iowa, II, 215-218. 1870.) Brief account of its surface features.

Notice of a Meteorite Fall. J. Torrey and E. H. BarEpsomite. bour. (Am. Geologist, VIII, 66. 1891.)

Its occurrence in Iowa. C. A. White. (Geol. Iowa, II, 305-306. 1870.) Reported from near Burlington.

Equivalency of Lime Creek Beds. H. S. Williams. . (Am. Jour. Sci., (3), XXV, 311. 1883.)

Evidence of Two Distinct Geological Formations in the Burlington Limestone. W.' $\mathrm{H}$.' Niles and Charles Wachsmuth. (Am. Jour. Sci., (2), XLII, 95-99. 1866.) 
Evidence that Lake Cheyenne Continued till the Ice Age. J. E. Todd. (Proc. Am. As. Ad. Sci, XXXVII, 202203. 1890.)

Exogenous Leaves in the Cretaceous Rocks of Iowá. C. A. White. (Am. Jour. Sci., (2), XLIV, 119. 1867.)

Fall of the Meteoric Stones in Iowa. C. U. Sheppard. (Am. Jour. Sci., (2), IV, 288-289. 1847.)

Farnsworth, J. P. Pockets Containing Fire-Clay and Carboniferous Material in the Niagara Limestone at Clinton, Iowa. (Am. Geologist, vol. II, pp. 331-334. Minneapolis, 1888.) Short account of pockets of fireclay at Clinton.

Farnsworth, J. P. The Geology and Topography of Iowa with a Sanitary Point of View. (Iowa State Board of Health, Second Biennial Report, pp. 383-396. Des Moines, 1883.) A brief sketch of the surface features of Iowa.

Fauna of the Lower Carboniferous Limestones of Spergen Hill., Ind., with a Revision of the Descriptions of its Fossils Hitherto Published and Illustrations of the Species from the Original Type Series. R. P. Whitfield. (Bul. Am. Mus. Nat. Hist., I, 39-97. 1882.)

Fayette County.

New Species of Paleozoic Fossils. S. Calvin. (Bul. Lab. Nat. Hist. State Univ. Iowa, I, 174. 1890.) Notice of the geology. J. D. Whitney. (Geol. Iowa, I, 302-305. 1858.)

Final Report of the U. S. Geological Survey of Nebraska and Portions of the Adjacent Territories. F. V. Hayden. (pp. 1-245. 1872.)

First Annual Report of the State Geologist. C. A.White. (First and Second Ann. Rep. State Geologist, 5-8. 1868.) 
First Biennial Report of the State Mine Inspector for the . years 1882-1883. P. C. Wilson. (pp. 1-94. 1883.) Fire-Clay.

In Clinton county. J. P. Farnsworth. (Am. Geologist, II, 331-334. 1888.)

Properties. C. A. White. (Geol. Iowa, II, 327. 1870.) Brief references to some of its properties.

Fishes.

Description of new species. 0. H. St. John and A. H. Worthen. (Geol. Sur. Illinois, VI, 245-288. 1875.)

Fauna of the Lower Coal Measures of Central Iowa. C. R. Keyes. (Proc. Acad. Nat. Sci., Phila., 231-247. 1888.)

From Lower Garboniferous of Iowa. O. H. St. John and A. H. Worthen. (Geol. Sur. Illinois, VII, 53264. 1883.)

From eastern Nebraska. F. B. Meek. Final Report U. S. Geol. Sur. Nebraska, pt. ii, 83-245. 1872.)

Of central Iowa. C. R. Keyes. (Proc. Acad. Nat. Sci., Phila., 231-247. 1888.)

Occurrence of fish remains in the Carboniferous limestone. A. H. Worthen. (Proc. Am. As. Ad. Sci., $\mathrm{X}, 189-192$. 1856.)

New species from the Iowa Carboniferous. J. S. Newberry and A. H. Worthen. (Geol. Sur. Illinois, IV, 246-374. 1870.)

New species from the Carboniferous. J. S. Newberry and A. H. Worthen. (Geol. Sur. Illinois, II, 9-134. 1868.)

Floyd County.

Distribution of Rockford Shales. C. L. Webster. (Proc. Davenport Acad. Nat. Sci., V, 100-109. 1887.) 
Floyd County.-Continued.

Fauna at Lime Creek, Iowa. S. Calvin. (Am. Jour. Sci., (3), XXV, 434-436. 1883.)

New Genus of Corals from the Devonian. C. L. Webster. (Am. Naturalist, XXIII, 710-712. 1889.)

Notice of the geology. J. D. Whitney. (Geol. Iowa, I, 306-311. 1858.)

Remarkable Fauna at the Base of the Chemung in New York. H. S. Williams. (Am. Jour. Sci., (3), XXV, 97-104. 1883.) A number of comparisons of fossils of the Lime creek beds of Iowa with those of New York.

Pachyphyllum from the Rockford Shales. C. L. Webster. (Am. Naturalist, XXIII, 621-625. 1889.) Fossil Faunas of Central Iowa. C. R. Keyes. (Proc. Acad. Nat. Sci., Phila., 242-265. 1891.)

Fossil Wood from the Keokuk formation, Keokuk, Iowa

S. J. Wallace. (Am. Jour. Sci. , (3,) XV, 396. 1878.) Fossils.

American species of Polyphemopsis. . C. R. Keyes. (Proc. Acad. Nat. Sci., Phila., 1889. 299-302.) A revision of the species.

Attachment of Platyceras to Palæocrinoids. C. R. Keyes. (Proc. Am. Philosophical Soc., XXV, 231248. 1888.) Historical review and description of examples of Platyceras associated with various crinoids; and descriptions of four new species of Gasteropods.

Carboniferous Echinodermata of the Mississippi Basin. C. R. Keyes. (Am. Jour. Sci., (3), XXXVIII, 186193. 1889.) A sketch of the crinoids and deposits of the lower Carboniferous of the Mississippi basin. Carboniferous Fossils from Jackson County. Herbert 
Fossils.-Continued.

Osborn. (Proc. Iowa Acad. Sci., 1890-1891, 115. 1892.) Lepidodendron and Calamites reported from a Coal Measure pocket in Jackson county.

Certain forms of Straparollus from Southeastern Iowa.

C. R. Keyes. (Am. Geologist, V, 193-197. 1890.)

Notes on the species of this genus occurring near Burlington.

Check-List of the Palrezoic Fossils of Wisconsin, Minnesota, Iowa, Dakota and Nebraska. B. Bierbauer. (Bul. Minnesota Acad. Nat. Sci., III, 206-247. 1888.)

Classification of the Crinoidea. C. R. Keyes. (Am.

$\therefore$ Naturalist, XXIII, 153. 1889.) Brief remarks on the Classification of the order and changes necessitated by the discovery of the ventral structure of Taxocrinus (from the Kinderhook, near Marshalltown, Iowa).

Coal Measures of Central Iowa. C. R. Keyes. (Am. Geologist; II, 996-404.. 1888.) List of some of the species found in the middle Coal Measures at Des Moines.

Contribution to the Fauna of the Lower Coal Measures of Central Iowa. C. R. Keyes. (Proc. Iowa Acad. Sei., 1890-1891, 22-23. 1892.) A preliminary note. Three species described from the Lower Coal Measures at Des Moines.

Cretaceous and Carboniferous species in Iowa drift. C..A. White. (Geol. Iowa, I; 98. 1870.)

Cretaceous fossils in the drift of Hardin county. C. A. White. (Am. Geologist, I, 221-227. 1888.)

Description of the New Crinoids and Blastoids from the Hamilton Group. W. H. Barris. (Proc. Dav- 
Fossils.-Continued.

enport Acad. Sci., IV, 88-94. 1885.) Description of the new species Eleacrinus obovatus from Iowa.

Description of new species. D. D. Owen. /(Rep. Geol. Sur. Wis., Iowa and Minn. App., art. i, 573-587. 1852.)

Description of New Species of Crinoids. D. D. Owen and B. F. Shumard. (Rep. Geol. Sur. Wis., Iowa and Minn. App. art. ii, 587-598. 1852.)

Description of a New Species of Spirifera from the Hamilton Group near Iowa City, Iowa. S. Calvin. (Bul. Lab. Nat. Hist. State Univ. Iowa, I, 28-29. 1888.) .

Differences between specimens of the Acervularia. S. Calvin. (Am. Geologist, IX, 255-258. 1892.) Short notes.

Difference between specimens of the Acervularia. S. Calvin. (Proc. Iowa Acad. Sci., 1890-1891, 30-32. 1892.) Short notes.

Distribution in the Loess. C. R. Keyes. (Am. Geologist, VI, 119. 1889.)

Eastern Extension of the Cretaceous in Iowa. C. R. Keyes. (Proc. Iowa Acad. Sci., 1890-1891, 21. 1892.) Cretaceous fossils found in the drift at Des Moines.

Fauna of the Lower Coal Measures of Central Iowa. C. R.'Keyes. - (Proc. Acad. Nat. Sci., Phila., 1888, pp. 223-247. 1888.). Notes on many species found in the Coal Measures of the region. Three species described as new.

Fossil Faunas in Central Iowa. C. R. Keyes. (Proc. Acad. Nat. Sci., Phila., 242-265. 1891.) Notes and bibliographic references of the species found in 
Fossils.-Continued.

the lower Coal Measures of the central part of the state.

Fossil Remains of a Caribou. J. Leidy. (Proc. Acad. Nat. Sci., Phila., XXXI, 32-33. 1879.)

Fossils in Nishnabotna sandstone. C. A. White. (Geol. Iowa, I, 290. 1870.)

Fossils of the Iowa Loess. R. E. Call. (Am. Naturalist, $\mathrm{XV}, 585-586.1881$.

From Cretaceous, near Des Moines. C. R. Keyes. (Am. Naturalist, II, 396-404. 1888.) Notes on the species found in an erratic boulder. at Des Moines; also reference to fossils of the same age found in other parts of Iowa in the drift.

From Dark Shales Below the Devonian Limestone at Independence. S. Calvin. (Bulletin U. S. Geol. and Geog. Sur. Terr., IV, 725-730. 1878.) Brief remarks on some of the fossils and description of five new species.

From Lime creek, Iowa. S. Calvin. (Am. Jour. Sci., XXV, (3), 434-436. 1883.) Remarks on the fauna and description of a new species.

From the Chemung group at Burlington, Iowa. C. A. White and R. P. Whitfield. (Proc. Boston Jour. Nat. Hist., VIII, 289-306. 1862.) Observations upon the rocks, with descriptions of new species from the "Chemung" at Burlington.

From the Iowa Loess. R. E. Call. (Am. Naturalist, XV, 585-586: 1881.)

From the Loess of Iowa. C. R. Keyes. (Bul. Essex Inst., XX. 1889.)

From the Loess at Iowa City. B. Shimek. (Am. Geologist, I, 149-152. 1888.) 
Fossils.-Continued.

From the Lower Magnesian limestone. S. Calvin. (Am. Geologist, X, 144-148. 1892.)

From the Lower Coal Measures at Des Moines, Iowa. Charles R. Keyes. (Am. Geologist, II, 23-28. 1888.) A list of the species found, with brief notes on the stratigraphy.

From the Devonian of Iowa. C. R. Keyes. (Proc. Acad. Nat: Sci., Phila., pp. 247-248. 1888.) Two species are described as new.

From upper Coal Neasures of eastern Nebraska. F. B. Meek. (U. S. Geol. Surv. Nebraska, 83-245. 1872.) Incidental remarks on the occurrence of various Carboniferous species in Iowa.

From "Yellow" sandstones at Burlington, Iowa. A Winchell. (Proc. Acad. Nat. Hist., Phila., XV, 2-25, 1863.) Descriptions of new species and genera found in the yellow sandstone.

Gasteropods from Burlington. C. R. Keyes. (Proc. Acad. of Nat. Sci., 283-298. 1889.) Species from the Kinderhook and Burlington limestone.

Keokuk Beds and their Contained Fossils in the vicinity of Keokuk, Iowa. C. H. Gordon.' (Proc. Iowa Acad. Sci., 98-100. 1890.) The exact horizon of a number of species given.

Keokuk species of Agaricocrinus. C. H. Gordon. (Am. Geologist, V, 257-261. 1890.)

Leaves found in the Nishnabotna sandstone. C. A. White. (Geol. Iowa, I, 292-293. 1870.)

New Conocardium from the Iowa Devonian. C. R. Keyes. (Proc. Iowa Acad. Sci., 1890-1891, 23-24. 1892.) Description of the Conocardium altum from the Iowa Devonian. 
Fossils.-Continued.

New Genus of Corals from the Devonian. C. I. Webster. (Am. Naturalist, XXIII, 710-712. 1889.)

New species from the Devonian. S. Calvin. (Am. Geologist, I, 24-28. 1888.)

New species from the Kinderhook of Marshall county.

C. Wachsmuth and F. Springer. (Geol. Surv. IIlinois, VIII, 157-251. 1890.)

New species of organic remains from Iowa. J. Hall. (Geol. Sur. Wisconsin, pt. iii, 1-94. 1871.)

New Species of Palæozoic Fossils. S. Calvin. (Bul.

Lab. Nat. Hist. State Univ. Iowa, I, 173-181. 1890.)

Notes on the Rockford Shales. C. L. Webster. (Am. Naturalist, XXII, 444-446. . 1888.)

Notes of the Synonyny, Characters and Distribution of Spirifera Parryana Hall. S. Calvin. (Bul. Lab. Nat. Hist. State Univ. Iowa, I, 19-28. 1888.)

Observations on Geology and Paleontology of Burlington and Vicinity. C. A. White. (Boston Jour. Nat. Hist., VII, 209-235. 1860.) A list of species found at Burlington, with descriptions of seven new forms.

Observations on the Keokuk Species of Agaricocrinus. C. H. Gordon. (Proc. Iowa Acad. Sci., 100-101. 1890.)

Of the Cincinnati group, Hudson river shales or Maquoketa shales. C. A. White. (Geol. Iowa, I, 182. 1870.)

Ovibos Cavifrons from the Loess at Council Bluffs. W. J. McGee. (Am. Jour. Sei., (3), XXXIV, 217-220. 1887.)

Pachyphyllum from the Rockford Shales. C. L. Webster. (Am. Naturalist, XXIII, 621-625. 1889.) 
Fossils.-Continued.

Platyceras attached to the fossil crinoids. C. R. Keyes. (Am. Naturalist, XXII, 924-925. 1889.) Brief accounts of certain species of gasteropods found attached to Iowa crinoids.

Preliminary Note on the Sedentary Habits of Platyceras. C. R. Keyes. (Proc. Iowa Acad. Sci., 18901891, 24. 1892.) A preliminary account of the attachment of gasteropods to crinoids.

References to Iowa fossils. K. A. Zittel. (Handbuch der Palæontologie, I Band, 1-765. 1880.)

Remarkable Fauna at the Base of the Burlington Limestone in Northeastern Missouri. C. R. Keyes. (Am. Jour. Sci., (3), XLIV, 247-252. 1892.)

Remarkable Fauna at the base of the Chemung in New York. H. S. Williams. (Am. Jour. Sei., (3), XXV, 97-104. 1883.) A number of comparisons of fossils of the Lime creek beds of Iowa with those of New York.

Reproductions of figures of Iowa fossils. J. P. Lesley. (Geol. Sur. Penn., Rep. P4, I-III, 1-1283. 1890.) Sedentary Habits of Platyceras. C. R. Keyes. (Am. Jour. Sci., (3), XXXVI, 269-272. 1889.) Notes on various species found intimately associated with fossil crinoids in the lower Carboniferous of Iowa: Soleniscus ; its Generic Characters. C. R. Keyes. (Am. Naturalist, XXIII, 420-424. 1889.) A discussion of the generic characters and its relations.

Species found in the Loess. B. Shimek. (Bul. Lab. Nat. Hist. State Univ. Iowa, I, 200-214. 1890.) Sphærodoma: a Genus of Fossil Gasteropods. C. R. Keyes. (Proc. Acad: Nat. Sci., Phila., pp. 303-309. 1889.) A revision of the old genus Macrochilus. 
Fossils.-Continued.

Sponges from Iowa. E. O. Ulrich. (Geol. Surv. Illinois, VIII, 243-251. 1890.)

Stratigraphy of the Carboniferous in Central Iowa. C. R. Keyes. (Bul. Geol. Soc. America, II, 277292. 1891.) List of the fossils found in the lower Coal Measures in the central part of the state with remarks on the same.

Synopsis of American Carbonic Calyptræidæe. C.R. Keyes. (Proc. Acad. Nat. Sci., Phila., 150-180. 1890.) The generic characters and the sedentary habits fully described; together with diagnoses of all the species found in the American Carboniferous. Biblographic references and stratgraphic horizons given.

Synoptical Table and figures of the Loess species at Des Moines. W. J. McGee and R. E. Call. (Am. Jour. Sci., (3), XXIV, 202-223. 1882.)

Table of species found in the Maquoketa shales. J. F. James. (Am. Geologist, V, 335-356. 1890.)

Transition Forms in Crinoids and Description of Five New Species. Charles. Wachsmuth and Frank Springer. (Proc. Acad. Nat. Sci., Phila., 224-266. 1878.) A sketch of the evolution of certain erinoids, chiefly from southeastern Iowa.

Variation of a Gasteropod. C. R. Keyes. (Am. Geologist, III, 329-333. 1889.) Specimen from Keokuk limestone at Keokuk figured and referred to. Wood found. C. H. Gordon. (Proc. Iowa Acad. Sci., 1887-9, 97-98. 1890.)

\section{Franklin County.}

Aluminum in Iowa. C. R. Keyes. (Proc. Iowa. Acad. Sci., 1890-1891, 29-30. 1892.) Announce- 
Franklin County.-Continued.

ment of the establishment of a plant for the manufacture of aluminum in Franklin county.

General description. C. A. White. (Geol. Iowa, II, 239-241. 1870.) The surface characters and material resources briefly described.

Reference to its surface deposits. C. A. White. (Second Ann. Rep. State Geologist, 119-121. 1868.)

\section{Fremont County.}

General description. C. A. White. (Geol. Iowa, I, 353-362. 1870.) The drainage, surface characters, geological details and material resources of the country described.

Short notes on the surface geology. C. A. White. Fuels: (First Ann. Rep. State Geologist, 54-56. 1868.)

Chemical report on the fuels of Iowa. G. Hinrichs. (Second Ann. Rep. State Geologist, 205-217. 1868.) A classification of the different kinds and their combustibility.

\section{Galena Limestone.}

Chemical analyses. J. D. Whitney. (Geol. Iowa, I, 350-356. 1858.)

Correlated with the Utica slate. C. D. Walcott. (Trans. Albany Inst., X, Adv. Sheets, 1-17. 1879.) Fossils mentioned from Iowa localities. R. P. .Whitfield. (Geol. Sur. Wisconsin, IV, 163-349. 1882.) General description. C. A. White. (Geol. Iowa, I, -176-180. 1870.). A description of the general characters, economic value and its fossils.

General description of the characters. James Hall. (Geol. Iowa, I, 60-63. 1858.)

Of northeastern Iowa. W. J. MंcGee. (Eleventh Ann. Rep. U. S. Geol. Sur., 327-329. 1892.) 
Gannett, Henry. A Dictionary of Altitudes in the United States. (Bul. U. S. Geol. Sur., No. 5, Iowa, pp. 105-112. Washington, 1884.)

Gas (Natural).

Gas Wells near Letts, Iowa. F. M. Witter. (Proc. Iowa Acad. Sci., 1890-1891, 68-70. 1892.) Gas reported as being found in a number of places near Letts, in Louisa county, and furnishing supplies for a number of families.

Gas Wells near Letts, Iowa. F. M. Witter. (Am. Geologist, IX, 319-321. 1882.)

Gas Wells near Letts, Iowa. F. M. Witter. (Proc. Iowa Acad. Sci., 68-70. 1892.)

Natural Gas and Oil in Iowa. C. R. Keyes. (Proc. Iowa Acad. Sci., I, pt. iii, pp. 15-18. 1893.)

Gass, J., and W. H. Pratt. Bones of the Mammoth in Washington County, Iowa. (Proc. Davenport Acad. Nat. Sci., vol. III, pp. 177-178. Davenport, 1882.) A description of the remains of the bones found and preserved.

\section{Gasteropods.}

American Species of Polyphemopsis. C. R. Keyes. (Proc. Acad. Nat. Sci., Phila., 299-302. 1889.) A revision of the species.

Attachment of Platyceras to Palæocrinoids and its Effects in Modifying the Form of the Shell. C. R. Keyes. (Proc. Am. Philos. Soc., XXV, 231-248. 1888.)

Certain Forms of Straparollus from Southeastern Iowa. C. R. Keyes. (Am. Geologist, V, 193-197: 1890.) Contribution to the Fauna of the Lower Coal Measures of Central Iowa. C. R. Keyes. (Proc. Iowa Acad. Sci., 1890-1891, 22-23. 1892.) A prelim- 
Gasteropods.-Continued.

inary note. Two species described from the Lower Coal Measures at Des Moines.

Description of new species from Iowa. J. Hall. (Geol. Iowa, I, Supp., 1-92. 1859.)

Description of new species from the Iowa Lower Carboniferous. F. B. Meek and A. H. Worthen. (Geol. Sur. Illinois, III, 289-565. 1868.)

Description of new species from Iowa rocks. F. B. Meek and A. H. Worthen. (Geol. Sur. Illinois, II, 143-411. 1866.)

Description of Lower Carboniferous species from Iowa.

C. A. White. (Proc. Bost. Soc. Nat. Hist., IX, 8-33. 1865.)

Distribution of fossils in the Loess. C. R. Keyes. (Am. Geologist, VI, 119. 1890.)

Fossil Faunas in Central Iowa. C. R. Keyes. (Proc.

Acad. Nat. Sci., Phila., 242-265. 1891.) Notes and bibliographic references of the species found in the lower Coal Measures of the central part of the state. From Burlington, Iowa. C. R. Keyes. (Proc. Acad. Nat. Sci., Phila., 283-298. 1889.)

From eastern Nebraska. F. B. Meek. (Final Report

U. S. Geol. Sur. Nebraska, pt. ii, 83-245. 1872.)

From the Iowa Loess. R. E. Call. (Am. Naturalist, $\mathrm{XV}, 585-586$. 1881.)

From the Loess at Iowa City. B. Shimek. (Am. Geologist, I, 149-152. 1888.)

From Iowa. J. Hall. (Nat. Hist. New York, Pal., V, pt. ii. 1879.) A number of references to fossils from Iowa.

From the Lower Magnesian limestone. S. Calvin. (Am. Geologist, X, 144-148. 1892.) 
Gasteropods.-Continued.

In the Loess of Central Iowa. R. E. Call. (Am. Naturalist, XV, 782-784. 1881.)

Loess fossils at Des Moines. W. J. McGee and R. E. Call. (Am. Jour. Sci., (3), XXIV, 202-223. 1882.) Gasteropoda, etc. J. Hall. (Nat. Hist. New York, Pal., V, pt. ii. 1879.)

Lower Carboniferous and Coal Measure species. C. A. White and ${ }^{2}$. H. St. John. (Trans. Chicago Acad. Scị., I, 115-127. 1867.)

New species from Burlington. A. Winchell. (Proc. Acad. Nat. Sci., Phila., 225. 1863.)

New Species of Palæozoic Fossils. S. Calvin. (Bul. Lab. Nat. Hist. State Univ. Iowa, I, 173-181. 1890.)

New species from Iowa. A. H. Worthen. (Geol. Surv. Illinois, VIII, 69-154. 1890.)

New species from Iowa. C. A. White. (Twelfth Ann. Rep. U. S. Geol. and Geog. Surv. Terr., 155171. 1883.)

New species from Paleozoic rocks of Iowa. C. A. White. (Proc. Acad. Nat. Sci., Phila., XXVIII, 27-34. 1877.)

New species from the Devonian. J. Hall and R. P. Whitfield. (New York State Cab. Nat. Hist., 23d Ann. Rep., 223-239. 1873.)

New species from Burlington. C. A. White and R. P. Whitfield. (Proc. Boston Soc. Nat. Hist., VIII, 289-306. 1862.)

Notes on the Rockford Shales. C. L. Webster. (Am. Naturalist, XXII, 444-446. 1888.)

Of central Iowa. C. R. Keyes. (Proc. Acad. Nat. Sei., Phila., 231-247. 1888.) 
Gasteropods.-Continued.

Platyceras Group of Palæozoic Gasteropods. C. R. Keyes. (Am. Geologist, X, 273-277. 1892.)

Preliminary Note on the Sedentary Habits of Platyceras. C. R. Keyes. (Proc. Iowa Acad. Sci., 18901891, 24. 1892.) A preliminary account of the attachment of gasteropods to crinoids.

Sedentary Habits of Platyceras. C. R. Keyes. (Proc. Iowa Acad. Sci., 1890-91, 24. 1892.)

Soleniscus; its Relations and Generic Characters. C. R. Keyes. (Am. Naturalist, XXIII, 420-429. 1889.)

Species found in the Loess. B. Shimek. (Bul. Lab. - Nat. Hist. State Univ. Iowa, I, 200-214. 1890.)

Species mentioned from Silurian rocks of Iowa. $R$. P. Whitfield. (Geol. Sur. Wisconsin, IV, 163-349. 1882.)

Sphærodoma; a Genus of Fossil Gasteropods. C. R. Keyes. (Proc. Acad. Nat. Sci., Phila:, pp. 303309. 1889.) A revision of the species formerly referred to Macrochilus.

Synopsis of American Carbonic Calyptræidæ. C. R.

Keyes. (Proc. Acad. Nat. Sci., Phila., pp. 150-181. 1890.) Description of all the species known.

Variation of a Gasteropod. C. R. Keyes. (Am. Geologist, III, 329-333. 1889:)

General Geology of Illinois. A. H. Worthen. (Geol. Sur. Illinois, I, 1-153. 1866.) Incidental references to Iowa.

General Geology of Iowa. James Hall. (Geol. Iowa, I, 34-146. 1858.)

General Preliminary Description of the Devonian Rocks of Iowa, which constitutes a Typical Section 
General, etc.-Continued.

of the Devonian Formation of the Interior Continental area of North America. C. L. Webster. (Am. Naturalist, XXIII, 229-243. 1889.)

Geological Chart of Part of Iowa, Wisconsin and Illinois.

D. D. Owen. (Report of a Geological Exploration of Part of Iowa, Wisconsin and Illinois, made in the Autumn of the Year 1839. [Washington], 1844.)

Geological Distribution of Fossil Plants. L. F. Ward. (U. S. Geol. Sur., 8th.Ann. Rep., 663-933. 1889.)

Geological History of the North American Continent.

J. Hall. (Pamphlet, 1-24. 1869.)

Geological Map of Iowa. C. A. White. (Geol. Iowa, I, 32. 1870.)

Geological Map of the Eastern Half of the State of Iowa ; by Legislative Authority. J. Hall, J. D. Whitney and A. H. Worthen. (Geol. Iowa, I. 1858.)

Geological Map of the Lead Region in the States of Wisconsin, Illinois and Iowa. J. D. Whitney. (Geol Sur. Wisconsin, I. 1862.)

Geological Map of the State of Iowa. C. A. White. (Geol. Iowa, II. 1870.)

Geological Section from the Mouth of Rock River Through the Blue Mounds to the Wisconsin River, in Connection with.a Geological Chart of Part of Iowa, Wisconsin and Illinois. D. D. Owen. (Rep. of Geological Exploration of Parts of Iowa, Wisconsin and Illinois made in the Autumn of the Year 1839, plate iii. Washington, 1884.)

Geological Structure and Relations of the Coal-bearing Strata of Central Iowa. C. R. Keyes. (Proc. Iowa Acad. Sci., 27-28. 1892.) 
Geology and Soils. J. E. Todd. (Proc. Iowa Hort. Soc., vol. XVI, 208-213. 1881.)

Geology and Topography of Iowa with a Sanitary Point of View. J. P. Farnsworth. (Iowa State Board of Health. Second Biennial Report, 383-396. .. 1883.)

Geology of certain counties. A. H. Worthen. (Geol. Iowa, I, 183-258. 1858.)

Geology of Keokuk, Iowa. C. H. Gordon. (Rep. Dep. Nat. Hist. Northwestern Univ., 11-19. 1891.)

Geology of Minnesota. N. H. Winchell. (Geol. and Nat. Hist. Sur. Minnesota, Final Rep, I, 697 pp. 1884.) Incidental references to Iowa.

Geology of Scott County, Iowa, and Rock Island County, Illinois, and the adjacent Territory. A. S. Tiffany. (1-34, Glass and Hoover, Printers, Davenport, 1885.)

Geology of the Des Moines valley. A. H. Worthen. (Geol. Iowa, I, 147-182. 1858.)

Geology of the lead region. J. D.. Whitney. Geol. Sur. Illinois, vol. I, 153-207. 1866.)

Geology of the Middle Region of Western Iowa. O. H. St. John. (Geol. Iowa, II, 1-200. 1870.)

Geology of the Middle Region of Western Iowa. O. H. St. John: (Second Ann. Rep. State - Geologist, 191201. 1868.)

Geology of the Western States. D. D. Owen. (Am. Jour. Sei., XLV, 151-153. 1843.)

Gildroy, James. Report of the Mine Inspector for the Second District. (Fourth Biennial Report of the State Mine Inspectors, 1888-9, pp. 56-114. 1889.) Short accounts of the openings in different parts of the state, with statistics and description of methods of operation. 
Gildroy, James. Report of the Mine Inspector of the Second District. (Fifth Biennial Report of the State Mine Inspectors, $1890-91$, pp. 55-92. 1891.) Short accounts of the different mines, with statements of borings.

Glacial Phenomena (General.) See Quaternary.

Gold.

In Iowa drift. C. A. White. (Geol. Iowa, I, 97. 1870.)

Gordon, C. H. Geology of Keokuk, Iowa. (Report Dep. Nat. Hist. Northwestern Univ., 1891, pp. 11-19. 1891.) A short account of the surface deposits at Keokuk, with sections and sketch-map of vicinity.

Gordon, C. H. Notes on the Geology of Southeastern Iowa. (Am. Geologist, vol. IV, pp. 237-239. Minneapolis, 1889.) A short account of the different borings with sections made in southeastern Iowa.

Gordon, C. H. Notes on the Fossil Wood from the Keokuk Limestone, Keokuk, Iowa. (Proc. Iowa Acad. Sci., 1887-1889, pp. 97-98. Des Moines, 1890.) Abstract of a paper read before the Academy.

Gordon, C. H. Observations on the Keokuk Species of Agaricocrinus. (Am. Geologist, vol. V, pp. 257-261, 1.plate. Minneapolis 1890.) A comparison of the species of Agaricocrinus represented at Keokuk.

Gordon, C. H. Observations on the Keokuk Species of Agaricocrinus. (Proc. Iowa Acad. Sci., 1887-1889, pp. 100-101. Des Moines, 1890.) Abstract of a paper read before the Academy. Occurrence of several species of the genus at Keokuk.

Gordon, C. H. On the Brecciated Character of the St. Louis Limestone. (Am. Naturalist, vol. XXIV, pp. 305-313. Philadelphia, 1890.) Description of the St. Louis rocks in southeastern Iowa. 
Gordon, C. H. On the Keokuk Beds and their Contained Fossils in the Vicinity of Keokuk, Iowa. (Proc. Iowa Acad. Sci., 1887-1889, pp. 98-100. . Des Moines, 1890.) Abstract of a paper read before the Academy. A detailed section of the rocks at Keokuk given.

Gordon, C. H. Quaternary Geology of Keokuk, Iowa, with Notes on the Underlying Rock Structure. (Am. Geologist. vol. IX, pp. 183-190. Minneapolis, 1892.) A short sketch, with sections, of the surface geology in the vicinity of Keokuk.

\section{Gravel.}

In the drift. C. A. White. (Geol. Iowa, I, 84. 1870.)

\section{Greene County.}

Analyses of coal. Rush Emery. (Geol. Iowa, II, 391-392. 1870.)

General description of the geology. O. H. St. John. (Geol: Towa, II, 130-138. 1870.) The geological features briefly described, with several sections.

Gurley, W. F. E., S. A. Miller and. Description of Some New Genera and Species of Echinodermata from the Coal Measures and Subcarboniferous Rocks of Indiana, Missouri and Iowa. (Pamphlet, 59 pp., 10 plates. Cincinnati, 1890.) See S. A. Miller and W. F. E. Gurley, 1890.

\section{"Guthrie County.}

Analyses of coal: Rush Emery. (Geol. Iowa, II, 387-388. 1870.)

Cretaceous rocks. C. A. White. (Proc. Am. As. Adv. Sci., XVII, 326-327. 1869.)

Description of the geological features. O. H. St. John. (Geol. Iowa; II, 95-130. 1870.) A detailed account of the leading geological features in various parts of 
Guthrie County.-Continued.

the county accompanied by numerous sections and illustrations.

Fossils in Nishnabotna sandstone. C. A. White.

(Geol. Iowa, I, 290. 1870.)

\section{Gypsum.}

Account of its occurrence at Ft. Dodge. C. A. White. (Second Ann. Rep. State Geologist, 136-140. 1868.) Depósits described in detail. C. R. Keyes. (Mon. Rev. Iowa Weather and Crop Service, IV, No. 3, 2-4. 1893.)

Its occurrence in Iowa. C. A. White. (Geol. Iowa, II, 293-303. 1870.) A rather full account, with sketch map and sections of the gypsum deposits in the vicinity of Ft. Dodge.

'Recent finds described in detail. G. R. Keyes. (Proc. Iowa, Acad.; Sci., I, pt. iii, 19-22. 1893.)

\section{Hackberry Shales.}

Of northeastern Iowa. W. J. McGee. (Eleventh

Ann. Rep. U. S. Geol. Sur., 314. 1892.)

Hall, C. W., and F. W: Sardeson. Palæozoic Formations of Southeastern Minnesota. (Bul. Geol. Soc. America, vol. III, pp. 331-368. Rochester, 1892.) Incidental references to Iowa stratigraphy.

Hall, James. Brachiopoda. (Nat. Hist. New York, Pal., vol. VIII, pt. i, pp. 1-367, 20 plates. Albany, 1892.) Numerous references to the occurrence of fossils in Iowa.

Hall, James. Contributions to the Geological History of the American Continent. (Proc. Am. As. Ad. Sci., vol. XXXI, pt. i, pp. 29-71. Salem, 1883.) References to the geology of the state. 
Hall, James. Contributions to the Palæontology of Iowa being Descriptions of Crinoidea and other Fossils. (Geol. Iowa, vol. I, Supp., pp. 1-92. Albany, 1859.) Description of new species of fossils from Iowa.

Hall, James. Description of New Species of Crinoidea from the Carboniferous Rocks of the Mississippi Valley. (Boston Jour. Nat. Hist., vol VII, pp. 251-328. Boston, 1861.) The majority of the species described are from Iowa.

Hall, James. Description of New Species of Crinoids. (Pamphlet, pp. 1-19. Albany, 1861.)

Hall, James. Description of New Species of Fossils from the Hamilton Group of Western New York, with Notices of others from the same Horizon in Iowa and Indiana. (New York State Cab. Nat. Hist., 13th Ann. Rep., App. F, pp. 76-94. Albany, 1860.)

Hall, James. Gasteropoda, etc. (Nat. Hist. New York, Pal., vol. V, pt. ii. Albany, 1879.) A number of references to fossils from Iowa.

Hall, James. General Geology of Iowa. (Geol. Iowa, vol. I, pp. 34-146. Álbany, 1858.) A short general account of the rocks of the State, with special reference to their geological relations, forms chapter ii. A general description of the geologieal formations of the State forms chapter iii.

Hall, James. Geological History of the North American Continent. (Pamphlet, pp. 1-24. Albany, 1869.) General allusions to geology of the Iowa region.

Hall, James. Iowa Geological Survey. (Geol. Iowa, vol. I, Supp., pp. 1-4. 1859.)

Hall, James. Lamellibranchiata. (Nat. Hist. New York, Pal., vol. V, pt. i, second half. Albany, 1885.) A number of references to species of fossils from Iowa. 
Hall, James. Note on the Geological Range of the Genus Receptaculites in American Palkozoic Strata. (New York State Cab. Nat. Hist., 16th Ann. Rep., App. D, pp. 67-69. Albany, 1863.)

Hall, James. Notes Explanatory of a Section from Cleveland, Ohio, to the Mississippi River, in the Southwest Direction, with Remarks upon the Identity of the Western Formations with those of New York. (Trans. As. Am. Geologists and Naturalists, pp. 267293. Boston, 1842.) Incidental referenees to the geology of Iowa.

Hall, James. Notes upon the Geology of the Western States. (Am. Jour. Sci., (1), vol. XLII, pp. 51-62. New Haven, 1842.) General remarks on the correlation of the rocks in the Mississippi valley.

Hall, James. Observations on the Genus Archimedes, or Fenestella, with Descriptions of Species, etc. (Proc. Am. As. Ad. Sci., pp. 170-180. Cambridge, 1857.) Species noted from Keokuk.

Hall, James. Observations upon the Carboniferous Limestones of the Mississippi Valley. (Am. Jour. Sci., (2), vol. XXIII, pp. 187-203. New Haven, 1857.) This is essentially a report of progress of the Iowa Geological Survey. A classification of the Iowa Carboniferous rocks is also given; the paper is practically all given in his report of the Geology of Iowa.

Hall, James. On the Carboniferous Limestone of the Mississippi Valley. (Proc. Am. As. Ad. Sci., vol. X, pp. 51-69. Cambridge, 1857.) Statement that the Coal Measures were deposited unconformably upon strata beneath, whether they were Carboniferous limestones, Devonian, Upper and Lower Silurian; the unconformity differing only in degree, and that the 
Hall, James.-Continued.

Coal Measures were laid down over a much greater area than they now occupy.

Hall, James. On the Occurrence of an Internal Convoluted Plate within the Body of Certain Species of Crinoidea. (Proc. Boston Soc. Nat. Hist., vol: X, pp. 3334. Boston, 1866.)

Hall, James. On the Parallelism of the Paleozoic Deposits of North America with those of Europe, etc. [Translated.] (Am. Jour. Sci., (2), vol. V, pp. 176183, and 259-270, New Haven, 1848; vol. VII, pp. 4551 and 218-231. New Haven, 1849.)

Hall, James. Organic Remains of the Niagara Group and Associated Limestones. (Geol. Sur. Wisconsin, 1859-1863, pt. iii, pp. 1-94, 18 plates. Albany, 1871.) A number of species from Iowa described.

Hall, James. Paleontology of New York. (Nat. Hist. New York, Paleontology, vol. IV, 422 pp. Albany, 1867.) A number of references to fossils occurring in Iowa.

Hall, James. Peliminary Notice of Newberria, a New Genus of Brachiopods; with Remarks on its Relations to Rensselæria and Amphegenia. (Tenth Ann. Rep. State Geologist of New York, pp. 91-102. Albany, 1891.) Species from Iowa noted.

Hall; James. Report of the Geological Survey of the State of Iowa. (Vol. I, pp. i-xv and 1-724. 1858.) PART FIRST (GEOLOGY).

Chapter $I$ is a description of the Physical Geography of the State. (See J. D. Whitney, 1858.)

Chapter II treats of the General Geology of the State, and the relations of the formations with those of the East. 
Hall, James.-Continued.

Chapter III describes in detail the different geological formations of the State from observations made during the years 1855-1857.

Chapter IV deals with the geology of Des Moines valley. (See A. H. Worthen, 1858.)

Chapter $\mathrm{V}$ is a detailed account of the geology of certain counties in southeastern Iowa. (See A. H. Worthen, 1858.)

Chapter VI is an account of the geology of various counties in the central and northern part of eastern Iowa. (See J. D. Whitney, 1858.)

Chapter VII is a chemical and economical report. - (See J. D. Whitney, 1858.) PART SECOND (PALEONTOLOGY).

Chapter VIII is made up of descriptions accompanied by illustrations of the numerous fossils of the different horizons as found in Iowa.

Hall, James. Report of the Geology of the State of Iowa. (Vol. I, pp. 474-724, Part Second, Paleontology, 29 plates. 1858.) This forms Chapter VIII of Vol. I, and is made up entirely of descriptions of fossils. A large number of genera and species are described as new.

Hall, James, and R. P. Whitfield. Description of New Species of Fossils from the Devonian Rocks of Iowa. (New York State Cab. Nat. Hist., 23d Ann. Rep., pp. 223-239. Albany, 1873.) A brief sketch of the Devonian formations of Iowa and descriptions of new fossils.

Hall; James, Whitney, J. D., and Worthen, A. H. Geological Map of the Eastern Half of the State of Iowa; by. Legislative Authority. (Geol. Iowa, vol. I. Albany, 1858.) 
Hamilton Formation.

Analyses of Lime. J. D. Whitney. (Geol. Iowa, I, 370-376. 1858.)

Brachiopods from various localities in Iowa. J. Hall. (Nat. Hist. New York, Pal., VIII, 1-267. 1892.) Conocardium from the Iowa Devonian. , C. R. Keyes. (Proc. Iowa Acad. Sci., 1890-1891, 23-24. 1892.) Description of Conocardium altum regarded as new. General deseription. C. A. White. (Geol. Iowa, I, 184-188. 1870.) The general characters, economic value and geographical age of various beds, with their fossils briefly deseribed.

Description of New Blastoids. W. H. Barris. (Geol. Sur. Illinois, VII, 357-364. 1883.)

Description of the New Crinoids and Blastoids from the Hamilton Group. W. H. Barris: (Proc: Davenport Acad. Sci., IV, 88-94. 1885.) Description of the new species Elxacrinus obovatus.

Description of the geological features along the Cedar and Iowa rivers in eastern Iowa. D. D. Owen. (Rep. Geol. Sur., Wis., Iowa and Minn., 77-90. 1852.)

Description of new species of fossils. J. Hall. (New York State Cab. Nat. Hist., 13 Ann. Rep., App. F, 76-94. 1860.)

Description of new species of fossils. F. B. Meek and A. H. Worthen. (Geol. Sur. Illinois, III, 289-565. 1868.)

Description of a New Species of Spirifera from the Hamilton Group near Iowa City, Iowa. S. Calvin. (Bul. Lab. Nat. Hist. State Univ. Iowa, I; 28-29. 1888.)

Description of Devonian fossils from Iowa. James Hall. (Geol. Iowa, $I, 476-516 . \quad 1858$. 


\section{Hamilton Formation.-Continued.}

General description of the characters. James Hall. (Geol. Iowa, I, 85-88. 1858.)

In Scott county. A. S. Tiffany. (Geol. Scott County, etc., 19-26. 1885.)

New Species of Palæozoic Fossils. S. Calvin. (Bul. Lab. Nat. Hist. State Univ. Iowa, I, 174. 1890.)

New species of fossils. J. Hall and R. P. Whitfield. (New York State Cab. Nat. Hist., 23d Ann. Rep., 223-239. 1873.)

New crinoids from Scott county. F. B. Meek and A. H. Worthen. (Proe. Acad. Nat. Sei., Phila., XVII, 138-143. 1865.)

Paleontology of New York. James Hall. (Nat. Hist. New York, Paleontology, IV, 422 pp. 1867.) A number of references to fossils occurring in Iowa. Preliminary notice of Newberria. J. Hall. (Tenth Ann. Rep. State Geologist of New.York, 91-102. 1891.) Species from Iowa noted.

Stereocrinus, Barris. W. H. Barris. (Proc. Davenport Acad. Sci., IV, 102-104. 1885.) Described as a new genus.

Two new species. C. R. Keyes. (Proc. Acad. Nat. Sei., Phila., 247-248. 1888.)

\section{Hamilton County.}

Brief notes on the geology. C. A. White. (First Ann. Rep. State Geologist, 25-26. 1868.)

General deseription. C. A. White. (Geol. Iowa, II, 256-257. 1870.) Brief reference to the geology.

New Species of Paleozoic Fossils. S. Calvin. (Bul. Lab. Nat. Hist. State Univ. Iowa, I, 178-179. 1890.) 
Hancock County.

General description. C. A. White. (Geol. Iowa, II, 247-249. 1870.) Brief general account of the surface characters.

Hardin County.

Analyses of coal. Rush Emery. (Geol. Iowa, II, 392-393. 1870.)

Cretaceous fossils in the drift. C. A. White. (Am. Geologist, I, 221-227.. 1888.):

Geological notes. C. A. White. (First Ann. Rep. State Geologist, 21-25. 1868.) . .

Geological notes. J. D. Whitney. (Geol. Iowa, I, 266-273. 1858.)

General description. C. A. White. (Geol. Iowa, II, 257-258. 1870.) Very brief general reference to the geology of the county.

Harrison County.

Description of the geology. O. H. St. John. (Geol. Iowa, II, 175-182. 1870.) The surface features and soil described and the upper Coal Measures noted in the vicinity of Logan.

Haworth, Erasmus. Millerite. (Science, vol. VII, p. 369. New York, 1886.) The occurrence of Millerite in the Keokuk limestone near Keokuk is noted.

Hayden, F. V. (Final Report of the U. S. Geological Survey of Nebraska and Portions of the Adjacent Territories, pp. 1-79. 1872.) A number of incidental references to the geology of western Iowa.

Heer, O., J. Capellini et. Les Phyllites Crétacees du Nebraska. (Mém. Soc. Helvétique, des Sci. Nat., t. XXII, pp. 1-24. 1867.) See J. Capellini et O. Heer, 1867. 


\section{Henry County.}

General description of the geology. A. H. Worthen. (Geol. Iowa, I, 209-219. 1858.) Brief general account of the geological formations of the county. Helderberg (Upper).

General description of the characters. James Hall. (Geol: Iowa, I, 81-84. 1858.)

In Scott county. A. S. Tiffany. (Geol. Scott County, etc., 13-19. 1885.)

Herrick, W. H. Observations on Prairie Soil. (Proc. Iowa Acad. Sci., 1875-1880, p. 16. Iowa City, 1880.) An abstract of a more fully explained paper.

Hinrichs, Gustavus. Report of the State Chemist. (First Ann. Rep. State Geologist, pp. 9-10. Des Moines, 1868.) Short notes on the work done and mention of a number of minerals occurring in Iowa. Hinrichs, Gustavus. Report of the State Chemist. (Second Ann. Rep. State Geölogist, pp. 263-279. Des Moines, 1868.) The report embraces chemical notes on fuel, water, rocks and coal of Iowa; also notes on the minerals.

History of the Drift Deposits. of Iowa. J. E. Todd. (Proc. Iowa Hort. Soc., XVIII, 316-327. 1883.)

\section{Howard County.}

Cretaceous fossils in the drift. C. A. White. (Proc. Am. As. Adv. Sci., XXI, 187-192. 1873.)

Notice of the geology. J. D. Whitney. (Geol. Iowa, I, 306-312. 1858.)

\section{Hudson River Shales.}

Correlation of the Maquoketa Shales. J. F James. (Am. Geologist, V, 335-356. 1890.)

General description. C. A. White. (Geol. Iowa, I, 180-182. 1870.) The general characters, economic 
Hudson River Shales.-Continued.

value and geological age of these rocks in Iowa described, with brief references to their sections and the fossils contained. See also Maquoketa Shales. General description of the characters. James Hall. (Geol. Iowa, I, 64-70. 1858.)

Of northeastern Iowa. W: J. McGee. (U. S. Geol. Sur., 11th Ann. Rep., 326-327. 1892.)

Section of the Maquoketa Shales in Iowa. J. F. James. (Proc. Am. As. Ad. Sci.; XXXVII, 250251. 1890.)

Humboldt County.

General geological description. C. A.White. (Geol. Iowa, II, 243-245. 1870.) Brief account of surface features; and mention of lower Carboniferous rocks.

Huntington, Oliver W. Catalogue of all the Recorded Meteorites; with Descriptions of the Specimens in the Harvard College Collection, including the Cabinet of the late J. Lawrence Smith. (Proc. Am. Acad. Art. and Sci., New Ser., vol. XV, pp. 37-110. Boston, 1887.) Several references to meteoric falls in Iowa. Hydrography.

General drainage features. C. A. White. (Geol. Iowa, I, 35-70. 1870.) General course and character of the rivers, with estimates of average fall of the principal streams. Also special description of the different water courses.

\section{Ida County.}

General surface features described. O. H. St. John. (Geol. Iowa, II, 158-164. 1870.)

\section{Igneous Rocks.}

Iowa Volcano. C. R. Keyes. (Mon. Rev. Iowa Weather and Crop Service, IV, 5-6. 1893.) 
Igneous Rocks.-Continued.

Recent finds described. C. R. Keyes. (Proc. Iowa Acad. Sci., I, pt. iii, 19-22. 1893.)

Volcanic Eruption in Iowa, An Old. C. R. Keyes. (Science, XXI, 132. 1893.)

Independence Shales.

Of northeastern Iowa. IV. J. McGee. (U. S. Geol. Sur., 11th Ann. Rep., 320. 1892.)

Iowa (General).

Abstract of an Introduction to the Final Report on the Geological Surveys made in Wisconsin, Iowa and Minnesota.in the years 1847-1850, containing a Synopsis of the Geological Features of the Country. D. D. Owen. (Proc. Am. Assoc. Ad. Sci., V, pp. 119-131. 1851.)

Account of the peat and its occurrence. C. A. White.

(Second Ann. Rep. State Geologist, 121-135. 1868.) Additional Observations on Iowa Kames and Aasar.

W. J. McGee. (Proc. Iowa Acad. Sci., 1875-1880, 25. 1880.)

Age of Certain Sandstones near Iowa City. C. R. Keyes. (Proc. Iowa Acad. Sci., 1890-1891, 26. 1892.) Owing to the recent discovery of fossils in the sandstones near Iowa City the suggestion is made that their age may be Kinderhook (lower Carboniferous) instead of upper Coal Measures as have been heretofore regarded.

Allusions to Iowa minerals. D. T. Day. (U.S. Geol. Sur., Statistical Papers, 652 pp. 1890.)

Analyses of various kinds of rocks. G. Hinrichs.

(Second Ann. Rep. State Geologist, 238-247. 1868.) Annual Deposits of the Missouri River During the Post-Pliocene. J. E. Todd. (Proc. Am. As. Ad. Sci., XXVI, 287-291. 1877.) 
Iowa (General).-Continued.

Artesian Wells. R. E. Call. (Monthly Rev. Iowa Weather and Crop Service, III, No. 2, 1-15. 1892.) Artesian Wells in Iowa. R. E. Call. (Proc. Iowa Acad. Sci., 1890-1891, 57-63. 1892.) An abstract of notes on the artesian wells in Iowa, with sketchmap.

Brachiopods mentioned from Iowa. R. P. Whitfield. (Bul. Am. Mus. Nat. Hist., I, 39-97. 1882.).

Building stones in Iowa. W. C. Day. (Rep. Mining Industry in the U. S. at the 11th Census, 1890, 593-666. 1892.)

Carboniferous Echinodermata of the Mississippi Basin.

C. R. Keyes. (Am. Jour. Sci., (3), XXXIII, 186193. 1889.)

Catalogue of the Paleozoic Fossils of North America. B. F. Shumard. (Trans. Acad. Sci., St. Louis, II, 334-407. 1866.)

Character of the Unconformability of the Iowa Coal Measures upon the Older Rocks. C. A. White. (Am. Jour. Sci., (2), XLV, 331-334. 1868.)

Charcoal Streak in the Loess. J. E. Todd. (Proc. Iowa Acad. Sci., 1875-1880, 21. 1880.)

Check-List of the Palæozoic Fossils of Wisconsin, Minnesota, Iowa, Dakota and Nebraska. B. Bierbauer. (Bul. Minnesota Acad. Nat. Sci., III, 206-247. 1891.)

Chemical analyses of Iowa water. G. Hinrichs. (Second Ann. Rep. State Geologist, 233-238. 1868.)

Chemical analysis of the Linn county fall of meteorites. C. U. Sheppard. (Am. Jour. Sci., (2), VI, 402-417. 1848.)

Chemical report on the fuels of Iowa. G. Hinrichs. 
Iowa (General),-Continued.

(Second Ann. Rep. State Geologist, 205-217. 1868.)

A classification of the different kinds of fuels and comparisons of their combustibility.

Chemistry of Artesian Wells. R. E. Call. (Monthly Rev. Iowa Weather and Crop Service, II, No. 2, 1-5. 1892.)

Classification of the Lower Carboniferous Rocks of the Mississippi Valley. C. R. Keyes. (Washington: Judd and Detweiller, printers, 1-24. 1892.) Sections and details of some of the lower Carboniferous rocks in southeastern Iowa described; with allusions to the Coal Measures of the central part of the state.

Complete Series of Superficial Geological Formations in Northeastern Iowa. W. J. MeGee. (Proc. Am. As. Ad. Sci., XXVII, 198-221. 1878.)

Contribution to the Geological History of the American Continent. J. Hall. (Proc. Am. As. Ad. Sci., XXI, pt. i, 21-71. 1883.) References to the geology of the state.

Contributions to the Palæontology of Iowa. J. Hall. (Geol. Iowa, I, Supp., 1-92. 1859.)

Composition and Proximate Analyses of Iowa Coals. G. Hinrichs. (Second Ann. Rep. State Geologist, 248-268. 1868.)

Correlation of the Cambrian. C. D. Walcott. (U. S. Geol. Sur.,Bul. 81, 187-188. 1891.)

Correlation of the Devonian and Carboniferous rocks. H. S. Williams. (U. S. Geol. Sur., Bul. 80, 1-279. 1891.)

Correlation of Maquoketa Shales. J. F. James. (Am. Geologist, V, 335-356. 1890.) 
Iowa (General).-Continued.

Cretacous Deposits at the Mouth of the Big Sioux. F. B. Meek. (U. S. Geol. Sur. Ter., IX, p. xxv. 1876.)

Cretaceous Rocks near Sioux City: J. Marcou. (Bul. Soc. géol. de France, (2), t. XXIV, 56. ‘ 1866.)

Crinoids from Iowa. A. H. Worthen. (Geol. Sur. Illinois, VII, 264-322. 1883.)

Deposits of gypsum described in detail. C. R. Keyes. (Mon. Rev. Iowa Weather and Crop Service, IV, No. 3, 2-4. 1893.)

Description of Burlington fossils. James Hall. (Geol. Iowa, I, 524-605. 1858.)

Description of Devonian fossils. James Hall. (Geol. Iowa, I, 476-516, 1858.)

Description of fossil fishes. O. H. St. John and A.H.

Worthen. (Geol. Sur. Illinois, VII, 53-264. 1883.) Description of fossils from the Kinderhook. James Hall. (Geol. Iowa, I, 517-523. 1858.)

Description of geological features along the Cedar and Iowa rivers in eastern Iowa. D. D. Owen. (Rep. Geol. Sur. Wis., Iowa and Minn., 77-90. 1852.)

Description of the geology of southwestern Iowa. C. A. White. (Am. Jour. Sci., (2), XLIV, 23-31. 1867.)

Description of Keokuk fossils. James Hall. (Geol. Iowa, I, 606-667. 1858.)

Description of Lower Carboniferous rocks in southeastern Iowa. D. D. Owen. (Rep. Geol. Sur. Wis., Iowa and Minn., 90-105. 1852.)

Description of lower Coal Measure, fossils. James Hall. (Geol. Iowa, I, 711-724. 1858.) 
Iowa (General).-Continued.

Description of Lower Magnesian Limestone. D. D. Owen. (Rep. Geol. Sur. Wis., Iowa and Minn., 58-69. . 1852.)

Description of lower Sandstone of the Upper Mississippi (Potsdam). D. D. Owen. (Geol. Sur. Wis., Iowa and Minn., 48-58. 1852.) A detailed account of its lithological characters, range and. paleontology.

Description of new genera and species of fossils. C. A. White and O. H. St. John. (Pamphlet, pp.1-3. Iowa City, 1867.)

Description of New Species of Crinoidea. J. Hall. (Pamphlet, pp. 1-19. 1861.)

Description of new species of crinoids. A. H.Worthen.

- (Illinois State Mus. Nat. Hist., Bul. No. 1; 1-39. 1882.)

Description of new species of fishes. J. S. Newberry and A. H. Worthen. (Geol. Sur. Illinois, I, 9-134. 1886.)

Description of new species of fishes from the Iowa Lower Carboniferous rocks. O. H. St. John and A. H. Worthen. (Geol. Sur. Illinois, VI, 245-288. 1875.)

Description of new species of fossils. F. B. Meek and A. H. Worthen. (Geol. Sur. Illinois, V, 323-619. 1873.)

Description of new species of fossils. F. B. Meek and A. H. Worthen. (Geol. Sur. Illinois, III, 289-565. 1868.)

Description of new species of fossils from Iowa rocks. F. B. Meek and A. H. Worthen. (Geol. Sur. Illinois, II, 143-411. 1866.) 
Iowa (General).-Continued.

Description of new. species of fossils from the Devonian. J. Hall. (New York State Cab. Nat. Hist., 13th Ann. Rep., App. F, 76-94. 1860.)

Description of new species of fossils from the Devonian and Carboniferous. C. A. White. (Proc. Bost. Soc. Nat. Hist. , IX, 8-33. 1865.)

Description of new Subcarboniferous and Coal Measures fossils. C. A. White and O. H. St. John. (Trans. Chicago Acad. Sci., I, 115-127. 1867.).

Description of Polyzoans. A. H. Prout. (Geol. Sur. Illinois, II, 412-424. 1866.)

Description of the Quarries and Quarry Regions of Iowa. W. J. McGee. · (Tenth Census 'U. S., X, Rep. Building Stones, 256-265. 1883.)

Description of rocks in eastern Kansas and $\mathrm{Ne}$ braska and their relation to those of adjacent states, etc. F. B. Meek. (Am. Jour. Sci., (2), XXXIX, 157-174. 1865.) Numerous incidental references to the geology of western Iowa.

Description of St. Louis fossils. James Hall. (Geol. Iowa, I, 667-677. 1858.)

Description of St. Peter sandstone. D. D. Owen. (Rep. Geol. Sur. Wis., Iowa and Minn., 69-71. 1852.)

Description of the Upper Carboniferous rocks along the Des Moines river. D. D. Owen. (Rep. Geol. Sur. Wis., Iowa and Minn., 105-133. 1852.)

Deep well at Emmettsburg, Iowa. N. H. Winchell. (Bul. Minnesota Acad. Sci., I, 387-390. 1880.)

Derivation of Iowa drift. C. A. White. (Am. Naturalist, II, 615-616. 1869.)

Distribution of fossils in the Loess. C. R. Keyes. (Am. Geologist, VI, 119. 1890.) 
Iowa (General).-Continued.

Distribution of fossil species in the Paleozoic rocks of Iowa, Wisconsin and Minnesota. D. D. Owen and B. F. Shumard. (Proc. Am. Assoc. Adv. Sci., V, 235. 1851.)

Drift Phenomena of Southwestern Iowa. C. A.White. (Am. Jour. Sci., (2), XLIV, 119. 1867.) Additional note to an article of the same title.

Driftless area of the upper Mississippi. T. C. Chamlin and R. D. Salisbury. (U. S. Geol. Sur., 6th Ann. Rep., 199-322. - 1886.)

Eastern Extension of the Cretaceous in Iowa. C. R. Keyes. (Proc. Iowa Acad. Sci., 1890-1891, 21. 1892.) Notes on Cretaceous fossils found in the drift and remarks on the eastern limits of the rocks in Iowa.

Evidence of Two Distinct Geological Formations in the Burlington Limestone. W. H. Niles and Charles Wachsmuth. (Am. Joùr. Sci., (2), XLII, 95-99, 1866.) A sketch of the Burlington beds and a list of crinoids found in the upper and lower divisions.

Equivalency of Lime Creek Beds. H. S. Williams. (Am. Jour. Sci., (3), XXV, 311. 1883.)

Fall of Meteoric Stones in Linn County. C. U. Sheppard. (Am. Jour. Sci. , (2), IV, 288-289. 1847.)

Fauna of the Lower Coal Measures of Central Iowa. C. R. Keyes. (Proc. Acad. Nat. Sci., Phila., 231247. 1888.)

Final Report of U. S. Geol. Surv. of Nebraska and Portions of the Adjacent Territories. F. V. Hayden. Numerous incidental allusions to the geology of western Iowa. 
Iowa (General).-Continued.

Folding of the Carboniferous Strata in Southwestern Iowa. J. E. Todd. (Proc. Iowa Acad. Sci., 1887'89, 58. 1890.)

Fossil Faunas in Central Iowa, C. R. Keyes. (Proc. Acad. Nat. Sci., Phila., 242-265. 1891.) Notes and bibliographic references of the species found in the lower Coal Measures of the central part of the state.

Fossils from the lower Magnesian limestone. S. Calvin. (Am. Geologist, X, 144-148. 1892.)

Fossils from the Loess of Iowa. C. R. Keyes. (Bul. Essex Inst., XX. 1889.)

Fossils mentioned from Iowa localities. R. P. Whitfield. (Geol. Sur. Wisconsin, IV, 163-349. 1882.) Fossils of the Iowa Loess. R. E. Call. (Am. Naturalist, $\mathrm{XV}, 585-586$. 1881.)

Galena limestone correlated with the Utica slate. C. D. Walcott:' (Trans. Albany Inst., X, Adv. Sheets, 1-17. 1879.)

Gasteropods from Iowa. J. Hall. (Nat. Hist. New York, Pal., V, pt. ii. 1879.) A number of references to fossils from Iowa.

General elassification of Iowa rocks. W. J. McGee. (U. S. Geol. Sur., 11th Ann. Rep., 304-334. 1892.) General notes on the geology. C. H. Gordon. (Am. Geologist, IV, 237-239. 1889.)

General references to the building stones of Iowa. G. P. Merrill. (Stones for Building and Decorating, 453 pp. New York, 1891.)

General references to the building stones of Iowa. G. P. Merrill. (Smithsonian Inst. Ann., Rep., 18851886, pt. ii, 277-648. 1889.) 
Iowa (General).-Continued.

General Preliminary Description of the Devonian Rocks of Iowa; which Constitutes a Typical Section of the Devonian Formation of the Interior Area of North America. C. L. Webster. (Am. Naturalist, XXIII, 229-243. 1889.)

Geological map of eastern Iowa. James Hall. (Geol. Iowa, I. 1858.)

Geological map of Iowa. D. D. Owen. (Rep. Geol. Sur. Wis., Iowa and Minn. 1852.)

Geological map of Iowa. C. A. White. (Geol. Iowa, II. 1870.)

Geological Structure and Relations of the Coal-bearing Strata of Central Iowa. C. R. Keyes. (Proc. Iowa Acad. Sci., 1890-1891,27-28. 1892.) A summary of observations made along the Des Moines river, ehiefly in the vicinity of Des Moines.

Geology and Soil. J. E. Todd. (Proc. Iowa Hort. Soc., XVI, 208-213. 1881.)

Geology of the Middle Region of Western Iowa. O.H. St. John. (Second Ann. Rep. State Geologist, 191201. 1868.)

Geology and Topography of Iowa in a Sanitary Point of View. J. P. Farnsworth. (Iowa State Board of Health, Second Biennial Rep., 383-396. 1883.)

Geology of the Western States. D. D. Owen. Am. Jour. Sci., (1), XLV, 151-153. 1843.). Incidental references to Iowa coal field.

History of the Drift Deposits of Iowa. J. E. Todd. (Proc. Iowa Hort. Soc., XVIII, 316-327. 1883.)

Incidental references to the geology of the State. N. H.Winchell. (Geol. and Nat. Hist. Sur. Minnesota, Final Rep., I, 697 pp. 1884.) 
Iowa (General).-Continued.

Investigation of the Archæan of the Northwestern States. R. D. Irving. (U. S. Geol. Sur., 5th Ann. Rep., 175-242. 1885.)

Iowa Drift. C. A. White. (Am. Naturalist, II, 615616. 1869.) Calls attention to the original site of the granite boulders found in Iowa.

Iowa Coal Beds. C. R. Keyes. (Coal Trade Jour., XXXII, 133, Mch. 1, 1893.)

Iowa Coal Beds. C. R. Keyes.: (Mon. Rev. Iowa Weather and Crop Service, IV, No. 1, 3-5. 1893.) Iowa Volcano. C. R. Keyes. (Mon. Rev. Iowa Weather and Crop Service, IV, 5-6. 1893.)

Keokuk group of the Mississippi valley. C. S. Beachler. (Am. Geologist, X, 88-96. 1892.)

Lakes of Iowa, Past and Present. C. A. White. Am. Naturalist, II, 143-155. 1868.)

Lamellibranchiata. James Hall. (Nat. Hist. New York, Pal. V, pt. i, second half. 1885.) A number of references to species of fossils from Iowa.

Leaves in the Cretaceous rocks of Iowa. C. A. White. (Am. Jour. Sei., (2), XLIV, 119. 1867.)

Les Phyllites Crétacees du Nebraska. J. Capellini et O. Heer. (Mém. Soc. Helvétique des Sci. Nat., XXII, 1-24. : 1857.)

List of Iowa crinoids and localities. C. Wachsmuth and F. Springer. (Proc. Acad. Nat. Sci., Phila., 1886, 64-226. 1886.)

List of Iowa crinoids and localities. C. Wachsmuth and F. Springer. (Proc. Acad. Nat. Sci., Phila., 1885, 225-365. 1885.)

List of Iowa crinoids and localities. C. Wachsmuth and F. Springer. (Proc. Acad. Nat. Sci., Phila., 1881, 177-414. 1881.) 
Iowa (General).-Continued.

List of Iowa crinoids and localities. C. Wachsmuth and F. Springer. (Proc. Acad. Nat. Sci., Phila., 1879, pp. 226-379. 1879.)

List of geological maps of Iowa. Jules Marcou and J. B. Marcou. . (Bul. U. S. Geol. Surv. No. 7, 89-101. 1884.)

List of Iowa mineral localities. E. S. Dana. (TextBook of Mineralogy, 15th ed., Ap. C., Iowa, 445. 1889.).

List of useful minerals and their localities. Anon. (U. S. Geol. Sur., Statistical Papers, 516 pp. 1886.) List of useful minerals and their localities. D.T. Day. (U. S. Geol. Sur., Statistical Papers, 832 pp. 1888.) List of useful minerals and their localities. Albert Williams, Jr. (U. S. Geol. Sur., Statistical Papers, 813 pp. 1883.)

List of useful minerals and their localities. D. T. Day. (U. S. Geol. Sur., Statistical Papers, 813 pp. 1887.)

List of useful minerals and their localities. Albert Williams, Jr. (U. S. Geol. Sur., Statistical Papers, $1016 \mathrm{pp} . \quad 1885$.

List of useful minerals and their localities. D. T.

Day. (U. S. Geol. Sur., Statistical Papers, 652 pp. 1888.)

Loess and its Soils. J. E. Todd. (Proc. Iowa Hort. Soc., XVII, 263-270. 1882.)

Loess and its fossils. B. Shimek. (Bul. Lab. Nat. Hist. State Univ. Iowa, II, 98-98. 1890.)

Loess and its fossils. B. Shimek. (Bul. Lab. Nat. Hist. State Univ. Iowa, I, 200-214. 1890.)

Loess of North America. R. E. Gall. (Am. Naturalist, XVI, 369-381. 1882.) 
Iowa (General).-Continued.

Marshall Group: A Memoir on its Geological Position, Characters and Equivalencies. in the United States. A. Winchell. (Proc. Am. Phil. Soc., XI, 57-83. 1869.)

Megalonyx found in Mills county. J. E. Todd. (Proc. Am. As. Ad. Sci., XXXVII, 202-203. 1889.)

Millerite. E. Haworth. (Science, VIII, 369. 1886.) Mineral resources of Iowa. D. T. Day. (U. S. Geol. Sur., Statistical Papers, 671 pp. 1892.)

Natural Gas in Iowa. R. E. Call. (Iowa Weather and Crop Service, III, 6-7. 1892.) A mention of several reported occurrences of natural gas in Iowa. Natural Gas and Oil in Iowa. C. R. Keyes. (Proc. Iowa Acad. Sci., I, pt. iii, pp. 15-18. 1893.)

Note on "Cone-in-Cone." C. A. White. (Am. Jour. Sci., (2), XLV, 400-401. 1868.)

Notes Explanatory of a Section from Cleveland, Ohio, to the Mississippi River. J. Hall. (Trans. As. Am. Geologists and Naturalists, 267-293. 1842.) Incidental references to the geology of Iowa.

Notes on the Geological Formations of Iowa. S. Calvin. (Pamphlet, printed at the World's Exposition at New Orleans, pp. 1-8. 1884.) A brief résumé of the geological formations of the state.

Notes on the Geology of the Western States. J. Hall. (Am. Jour. Sci., (1), XLII, 51-62. 1842.)

Notes on the Geology of a Part of the Mississippi Valley. W. J. McGee. (Geological Magazine, (2), VI, 412-420 and 353-362. 1879.)

Notes on Iowa minerals. G. Hinrichs. (Second Ann. Rep. State Geologist, 268-278. 1868.) 
Iowa (General)--Continued.

Notes on the Redrock Sandstone. C. R. Keyes. (Proc. Iowa Acad. Sci., 1890-1891, 26-27. 1892.) A preliminary account of the stratigraphical relations.

Notes on the Synonyny, Characters and Distribution of Spirifera Parryana Hall. S. Calvin. (Bul. Lab. Nat. Hist. State Univ. Iowa, I, 19-28. 1888.)

New Bryozoans: E. O. Ulrich. (Geol. Sur. Illinois, VIII, 283-688. 1890.)

New Fossil Crinoidea from the Paleozoic Rocks of the Western and Southern Portions of the United States. B. F. Shumard. (Trans. Acad. Sci., St. Louis, I, 71-80. 1858.)

New species of fossils from the Devonian. J. Hall and R. P. Whitfield. (New York State Cab. Nat. Hist., 23d Ann. Rep., 223-239. 1873.)

New species of fishes from the Iowa Carboniferous. J. S. Newberry and A. H. Worthen. (Geol. Sur. IIIinois, IV, 246-374. 1870.)

New Species of Blastoidea from the Paleozoic Rocks of the Western States. B. F. Shumard. (Trans. Acad. Sci., St. Louis, I, 238-248. 1858.)

New species of fossils from Iowa. C. A. White. (Twelfth Ann. Rep. U. S. Geol, and Geog. Surv. Terr., 155-171. 1883.)

New species of fossils from Iowa. C. A. White. (Rep. Geog. and Geol. Expl. and Surv. w. 100 Merid., IV, 1-219. 1875.)

New species of organic remains from Iowa. J. Hall. (Geol. Sur. Wisconsin, pt. iii, 1-94. 1871.)

Observations on the Geological Structure of the Valley 
Iowa (General).-Continued.

of the Mississippi. T. Nuttall. (Jour. Acad. Nat. Sci., Phila., II, 14-52. 1821.)

Observations upon the Drift Phenomena of Southwestern Iowa. C. A. White. (Am. Jour. Sci., (2), XLIII, 301-305. 1867.)

Observations upon the Carboniferous Limestones of the Mississippi Valley. J. Hall. (Am. Jour. Sci., (2), XXIII, 187-203. 1857.)

Observations upon the Drift Phenomena of Southwestern Iowa. C. A. White. (Second Ann. Rep. State Geologist, 143-148. 1868.)

Occurrence of Natural Gas in Iowa, and its Probable Future. C.R. Keyes. (Mon. Rev. IowaWeather and Crop Service, III, No. 12, 3-4. 1892.) A general account of the conditions necessary for a successful flow of oil and gas, with an account of how these conditions are satisfied within the limits of Iowa so far as is known.

On -some Iowa Kames and Aasar. W. J. McGee. (Proc. Iowa Acad. Sci., 1875-1880, 19! 1880.)

On the Parallelism of the Paleozoic Deposits of North America with those of Europe, etc. [Translated.] J. Hall. (Am. Jour. Sci., (2), V, 176183. 1848.)

On the Relation of Loess to Drift in Southwestern Iowa. J. E. Todd. (Proc. Iowa Acad. Sci., 18751880, 19. 1880.)

Ore Deposits of Southwestern Wisconsin. T. C. Chamberlin. (Geol. Sur. Wisconsin, IV, 367-568. 1882.) Origin of the Prairies; in Southwestern Iowa. J. E. Todd. (Am. Naturalist, XII, 91-96. 1878.)

Paleontology of New York. J. Hall. (Nat. Hist. 
Iowa (General).-Continued.

New York, Paleontology, IV, 422 pp. 1867.) A number of references to fossils occurring in Iowa. Paleontology of Eastern Nebraska. F. B. Meek. (Final Report U. S. Geol. Sur. Nebraska, pt. ii, 83245. 1872.)

Perisomic Plates of the Crinoids. Charles Wachsmuth and Frank Springer. (Proc. Acad. Nat. Sci., Phila., 1890, 325-392. 1890.) Incidental references to Iowa species.

Platyceras Group of Paleozoic Gasteropods. C. R. Keyes. (Am. Geologist, X, 273-277. 1892.)

Pleistocene History of Northeastern Iowa. W. J. McGee. (U. S. Geol. Sur., 11th Ann. Rep. 190577. 1892.)

Preliminary Paper on Artesian Wells in Iowa. R. E. Call. (Monthly Rev. Iowa Weather and Crop Service, II, 1-6. 1891.)

Principal Missisșippian Section. C. R. Keyes. (Bul. Geol. Soc. America, III, 283-300. 1892.) The recent investigations along the Mississippi river and the stratigraphical details described with a proposed new classification of the lower Carbon- iferous rocks in the Mississippi basin.

Producti found in the Western States and Territories, with Description of Twelve New Species. J. G. Norwood and Henry Pratten. (Jour. Acad. Nat. Sci., Phila., (2), III, 5-22. 1855.)

Proposed Economical Geological Survey of Iowa. [C. R. Keyes.] (Pamphlet, 8 pp. Des Moines, 1891.) Quartzite boulders in western Iowa. C. A. White. (Proc. Am. As. Adv. Sci., XVII, 340-342. 1869.) - Recent Wind Action upon the Loess. J. E. Todd. 
- Iowa (General).-Continued.

(Proc. Iowa Acad. Sci., 1875-1880, 21. 1880.)

Reference to the lead region of northeastern Iowa. J. D. Whitney. (Geol. Sur. Illinois, I, 153-207. 1866.)

References to Iowa fossils. K. A. Zittel. (Handbuch der Palæontologie, I Band, 1-765. 1880.)

Relations of Geology and Agriculture. W. J. McGee. (Proc. Iowa State Hort. Soc., XVI, 227-240. 1884.) Relation of the Cretaceous Deposits of Iowa to the Subdivisions of the Cretaceous Proposed by Meek and Hayden. S. Calvin. (Proc. Iowa Acad. Sci., I, pt. iii, pp. 7-12. 1893.)

Relation of the Devonian Faunas. H. S. Williams. (Am. Geologist, III, 230-233. 1889.)

Relative Position of Forest Beds and Associated Drift

Formations in Northeastern Iowa. W. J. MeGee.

(Am. Jour. Sci., (3), XV, 339-341. 1878.)

Remarkable Fauna at the Base of the Burlington

Limestone in Northeastern Missouri. C. R. Keyes.

(Am. Jour. Sci., (3), XLIV, 247-252. 1892.)

Remarkable Fauna at the base of the Chemung Group in New York. H. S.Williams. (Am. Jour. Sci., (3), XXV, 97-104. 1883.) The Devonian fauna of

Lime creek discussed and compared.

-Remarks on Prof. Geinitz's Views Respecting the Upper Paleozoic Rocks and Fossils of Southeastern Nebraska. F. B. Meek. (Am. Jour. Sci., (2), XLIV, 170-187. 1867.) Numerous incidental references to the geology of western Iowa.

Remarks on the Age of the Goniatite Limestone at Rockford, Indiana, and its Relations to the Black Slate of the Western States and to Some of the Suc- 
Iowa (General)-Continuced.

ceeding Rocks of the Latter. F. B. Meek and A. H. Worthen. (Am. Jour. Sci., (2), XXXII, 167-177. 1861.)

Richthofen's 'Theory of the Loess in the Light of the Deposits of the Missouri. J. E. Todd. (Proc. Am. As. Ad. Sci., XXVII, 231-239. 1878.)

Report of the Geological Survey of the State of Iowa.

C. A. White. (Vol. I, pp. i-viii and 1-391. Des Moines, 1870.)

Report of Progress of the Geological Survey. C. A. White. (First Ann. Rep. State Geologist, 1-4. 1867.)

Report of a Geological Exploration of Iowa, Wisconsin and Illinois, made under Instructions of the Secretary of the Treasury of the United States in the Autumn of 1839. (House of Rep., Exec. Doc., 26 Cong., 1st Sess., No. 239, 161 pp. 1840.)

Report Intended to Illustrate a Map of the Hydrographical Basin of the Upper Mississippi River. J. N. Nicollet. · (Sen. Doc., 26 Cong., 2nd Sess., V, pt. ii, No. 237. 1841.)

Reproductions of figures of Iowa fossils. J. P. Lesley. (Geol. Sur. Penn., Rep. P4, I-III, 1-1283. 18891890.)

Sedentary Habits of Platyceras. C. R. Keyes. (Am. Jour. Sci., (3), XXXVI, 269-272. 1888.)

Sketch of the Physical Geography of Iowa. R. E. Gall. (Ann. Rep. Iowa Weather and Crop Service, 12-18. 1891.)

Statistics of Iowa Coal Product. J. H. Jones. (Rep. Mining Industry in the U.S. at the 11 th Census, 1890, 342-422. 1892.) 
Iowa (General).-Continued.

Sterocrinus, Barris. W. H. Barris. (Proc. Acad. Nat. Sci., Davenport, IV, 102-104. 1885.) Described as a new genus.

Stratigraphy of the Carboniferous of Central Iowa. C. R. Keyes. (Bul. Geol. Soc. America, II, 277292. 1891.) Description of the stratigraphic relations of the various beds in the central part of the State.

Structure and Habits of Paleozoic Crinoids. F. B. Meek and A. H. Worthen. (Proc. Acad. Nat. Sci., Phila., XX, 323-334. 1868.)

Structure and Probable Affinities of Cerionites Dactylioides Owen. S. Calvin. (Proc. Iowa Acad. Sci., I, pt. iii, pp. 13-15. 1893.)

Surface Geology of the Raccoon River Region. O. H.

St. John. (Second Ann. Rep. State Geologist, 173190. 1868.)

Synopsis of American Carbonic Calyptræidæ. C. R.

Keyes. (Proc. Acád. Nat. Sci., Phila., pp. 150-181.

1890.) Description of all the species found.

Table of Altitudes. H. Gannett. (Bul. U. S. Geol. Sur. No. 5, Iowa, 105-112. 1884.)

Terminal Moraine of the Second Glacial Epoch. T.

C. Chamberlain. (U. S. Geol. Sur., 3rd Ann. Rep., 291-404. 1883.)

Topographic Types of Northeastern Iowa. W. J. McGee. (Proc. Am: As. Ad. Sci., XXXVII, 248249. 1890.)

Transitional Drift of a Portion of Northern Iowa. C. L. Webster. (Am. Naturalist, XXIV, 1182-1185. 1890.) 
Iowa (General).-Continued.

Two New Fossils from the Devonian. Charles $R$. Keyes. (Proc. Acad. Nat. Sci., Phila., 247-248. 1888.)

Unconformity of the Coal Measures upon the underlying rocks. J. Hall. (Proc. Am. As. Ad. Sci., $\mathrm{X}, 51-69$. 1857.)

Une Reconnaissance géologique au Nebraska. Jules Marcou. (Bul. Soc. géol. de France, (2), XXV, 137. 1864.)

Volcanic Eruption in Iowa. C. R. Keyes. (Science; XXI, 132. 1893.)

Iowa Artesian Wells. R. E. Call. (Monthly Rev. Iowa Weather and Crop Service, III, No. 3, 1-15. 1892.)

\section{Iowa County.}

Analysis of a Meteorite. J. Torrey and E. H. Barbour. (Am. Geologist, VIII, 66. 1891.)

Geological notes. J. D. Whitney. (Geol. Iowa, I, 260-266. 1858.)

Iowa Geological Survey. J. Hall. (Geol. Iowa, I, Supp., 1-4. 1859.)

Iowa Drift. C. A. White. (Am. Naturalist, II, 615616. 1869.)

Invertebrate Fossils Collected in Portions of Nevada, Utah, Colorado, New Mexico and Arizona by Parties of the Expeditions of $1871,1872,1873$ and 1874. C. A. White. (Rep. Geog. and Geol. Expl. and Surv. w. 100 Merid., IV, 1-219. 1875.)

Investigation of the Archæan of the Northwestern States. R. D. Irving. (U. S. Geol. Sur., 5th Ann. Rep., pp. 175-242. Washington, 1885.) Allusions are made to. the Sioux Quartzite of northwestern Iowa. 
Irving, R. D. Map of Wisconsin and adjoining portions of Michigan, Illinois, Iowa and Minnesota. Showing Geological Structure, Positions of the Principal Mineral Districts, etc. - Scale 20 miles to 1 inch. (Trans. Am. Inst. Mining Engrs., vol. VIII, p. 506. Easton, Pa., 1880.)

Irving, R. D. Preliminary Paper on an Investigation of the Archrean Formations of the Northwestern States. (U. S. Geol. Sur., 5th Ann. Rep., pp. 175-242. Washington, 1885.) Allusions are made to the Sioux Quartzite of northwestern Iowa.

Jackson County.

Carboniferous Fossils from Jackson County. Herbert Osborn: (Proc. Iowa Acad. Sci., 1890-1891, 115. 1892.) Lepidodendron and Calamites reported from a Coal Measure pocket in Jackson county.

General account of the geology. J. D. Whitney. (Geol. Iowa, I, 282-285. 1858.) Short notes on the geology of the county.

James, Joseph F. On the Maquoketa Shales and their Correlation with the Cincinnati Group of Southwestern Ohio. (Am. Geologist, vol. V, pp. 335-356. Minneapolis, 1890.) A general account of the shales as. represented in Iowa, with an attempt to correlate them with the Cincinnati shales of Ohio. A table of fossils found at this horizon in various states is also given.

James, Joseph F. Section of the Maquoketa Shales in Iowa. (Proc. Am. As. Ad. Sci., vol. XXXVII, pp. 250-251. Salem, 1890.) A section of the rocks given. Jones, John H. Statistics in Regard to Iowa Coal Product. (Rep. Mining Industry in the U. S. at the 11th Census, 1890, 343-422. 1892.) 


\section{Jasper County.}

Analyses of coal. Rush Emery. (Geol. Iowa, II, 388-389. 1870.)

General description. C. A. White. (Geol. Iowa, II, 262. 1870.) Brief references to the geology of the county.

Geological notes. J. D. Whitney. (Geol. Iowa, I, 266-273. 1858.)

\section{Jefferson County.}

General description. C. A. White. (Geol. Iowa, II, 273. 1870.) References to several coal mines located near Fairfield.

General description. A. H. Worthen. (Geol. Iowa, I, 231-239. 1858.) A brief account of the geology of the county, with several sections.

Notice of the occurrence of coal. C. A. White. (Second Ann. Rep. State Geologist, 94-96. 1868.)

\section{Johnson County.}

Age of Certain Sandstones near Iowa City. C. R. Keyes. (Proc. Iowa Acad. Sci., 1890-1891, 26. 1892.) Owing to the recent discovery of fossils in the sandstones near Iowa City the suggestion is made that their age may be Kinderhook (lower Carboniferous) instead of upper Coal Measures, as have been heretofore regarded.

Analyses of peat near Iowa City. Rush Emery. (Geol. Iowa, II, 402. 1870.)

Cretaceous fossils in the drift. C. A. White. (Proc. Am. As. Adv. Sci., XXI, 187-192. 1873.)

Description of the New Crinoids and Blastoids from the Hamilton Group. W. H. Barris. (Proc. Davenport Acad. Sci., IV, 88-94. 1885.) Deseription of the new species Elatacrinus obovatus. 
Johnson County.-Continued.

Description of a New Species of Spirifera from the Hamilton Group near Iowa City, Iowa. S. Calvin. (Bul. Lab. Nat. Hist. State Univ. Iowa, I, 28-29. 1888.)

Fossils from the Loess at Iowa City. B. Shimek. (Am. Geologist, I, 149-152. 1888.)

Geological notes. J. D. Whitney. (Geol. Towa, I, 260-266. 1858.)

Glacial seratehes at Iowa City. C. L. Webster. (Am. Naturalist, vol. XXI, 758-761. 1887.)

Iowa City and Birds' Eye "Marble." C. A. White. (Geol. Iowa, II, 316. 1870.)

New Conocardium from the Iowa Devonian. C. R. Keyes. (Proc. Iowa Acad. Sci., 1890-1891, 23-24. 1892.) Description of Conocardium altum from the Iowa Devonian.

New species of Devonian Annelid. S. Calvin. (Am. Geologist, I, 24-28. 1888.)

Notes on the geology. C. L. Webster. (Am. Naturalist, XXII, 408-419. 1888.)

Quarries. C. A. White. (Geol. Iowa, II, 308-309. 1870.)

Jones County.

Geological notes. J. D. Whitney. (Geol. Iowa, I, 278-282. 1858.)

Quarries. C. A. White. (Geol. Iowa, II, 309-311. 1870.)

Short sketch of building stones. C. A. White. (First Ann. Rep: State Geologist, 27-30. 1868.)

Keokuk Limestone.

Brachiopods from various localities in Iowa. J. Hall. (Nat. Hist. New York, Pal., VIII, 1-367. 1892.) 


\section{Keokuk Limestone.-Continued.}

Brachiopods mentioned from Iowa. R. P. Whitfield. (Bul. Am. Mus. Nat. Hist., I, 39-97. 1882.)

Classification of the Lower Carboniferous Rocks of the Mississippi Valley. C. R. Keyes. (Washington: Judd and Detweiller, printers, 1-24. 1892.) Sections and details of the rocks in southeastern Iowa.

Crinoids from Iowa. A. H. Worthen. (Geol. Sur. Illinois, VII, 264-322. 1883.)

Description of beds at Keokuk. C. H. Gordon. (Proc. Iowa Acad. Sci., 98-100. 1890.)

Description of fossil fishes. O. H. St. John and A.H.

Worthen. (Geol. Sur. Illinois, VII, 53-264. 1883.) Description of Iowa Fossils. James Hall. (Geol. Iowa, I, 606-667. 1858.)

Description of new fossils. A. H. Worthen. (Geol. Surv. Illinois, VIII, 69-154. 1890.)

Description of new species of Crinoidea. J. Hall. (Bost. Jour. Nat. Hist., VII, 251-328. 1861.)

Description of new species of crinoids. A. H.Worthen. (Illinois State Mus. Nat. Hist., Bul. No. 1, 1-39. 1882.)

Description of new species of fishes. O. H. St. John and A. H. Worthen. (Geol. Sur. Illinois, VI, 245288. 1875.)

Description of new species of fossils. F. B. Meek and A. H. Worthen. (Geol. Sur. Illinois, V, 323-619. 1873.)

Description of new species of fossils from Iowa rocks. F. B. Meek and A. H. Worthen. (Geol. Sur. Illinois, II, 143-411. 1866.)

Fossil wood from the Keokuk formation, Keokuk, 
Keokuk Limestone.-Continued.

Iowa. S. J. Wallace. (Am. Jour. Sci., (3), XV, 396. 1878.)

General description. C. A. White. (Geol. Iowa, I, 210-215. 1870.) A general description of the lithological characters, economic value and fossils.

In Des Moines county. A. H. Worthen. (Geol. Iowa, I, 202. 1858.)

In Henry county. A. H. Worthen. (Geol. Iowa, I, 216-217. 1858.)

In Jefferson county. A. H. Worthen. (Geol. Iowa, I, 237. 1858.)

In Lee county. A. H. Worthen. (Geol. Iowa, I, 193196. 1858.)

In Van Buren county. A. H. Worthen. (Geol. Iowa. I, 228. 1858.)

Keokuk group of the Mississippi valley. C. S. Beachler. (Am. Geologist, X, 88-96. 1892.)

Keokuk species of Agaricocrinus. C. H. Gordon. (Am. Geologist, V, 257-261: 1890.)

New Bryozoans. E. O. Ulrich. (Geol. Sur. Illinois, VIII, 283-688. 1890.)

New species of fishes described. J. S. Newberry and A. H. Worthen. (Geol. Sur. Illinois, II, 9-134. 1866.)

New species of fishes from Iowa. J. S. Newberry and A. H. Worthen. (Geol. Sur. Illinois, IV, 246-374. 1870.)

New species of fossils from Iowa. A. H. Worthen and F. B. Meek. (Geol. Sur. Illinois, VI, 489-532. 1875.)

New species of Polyzoans. A. H. Prout. (Geol. Sur. Illinois, II, 412-424. 1866.) 
Keokuk Limestone.-Continued.

New species of sponges. E. O. Ulrich. (Geol. Surv. Illinois, VIII, 243-251. 1890.)

Observations on the Genus Archimedes. J. Hall. (Proc. Am. As. Ad. Sci., X, 170-180. 1857.)

Observations on the Keokuk Species of Agaricocrinus. C. H. Gordon. (Proc. Iowa Acad. Sci., 1887-1889, 100-101. 1890.)

Of Iowa. W. J. MeGee. (U. S. Geol. Sur., 11th Ann. Rep., 312. 1892.) Brief mention.

Principal Mississippian Section. C. R. Keyes. (Bul. Geol. Soc. America, III, 283-300. 1892.) The recent investigations along the Mississippi river and the stratigraphical details described with a proposed new classification of the lower Carboniferous rocks in the Mississippi basin.

Synopsis of American Carbonic Calyptreide. C. R. Keyes. (Proc. Acad. Nat. Sci., Phila., 150-181. 1890.) Descriptions of all the species known.

Variation of a Gasteropod. C. R. Keyes. (Am. Geologist, III, 329-333. 1889.) Specimen from Keokuk figured.

Wood found. C. H. Gordon. (Proc. Iowa Acad. Sci., 1887-9, 97-98. 1890.)

\section{Keokuk County.}

Artesian well at Sigourney. C. H. Gordon. (Am. Geologist, IV, 237-239. 1889.)

General geology. C. A. White. (Geol. Iowa, II, 267. 1870.) Mere references.

Keyes, Charles R. A Remarkable Fauna at the Base of the Burlington Limestone in Northeastern Missouri. (Am. Jour. Sci., (3), vol. XLIV, pp. 247-252. New Haven, 1892.) Several references to the rocks of southeastern Iowit. 
Keyes, Charles R. A New Conocardium from the Iowa Devonian. (Proc. Iowa Acad. Sci., 1890-1, pp. 23-24. Des Moines, 1892.) Description of Conocardium altum, regarded as new.

Keyes, Charles R. A New Locality for Millerite. (Am. Geologist, vol. XI, p. 126. Minneapolis, 1893.) Description of some unusually fine examples of the mineral recently found at Keokuk.

Keyes, Charles R. An Iowa Voleano. (Mon. Rev. Iowa Weather and Crop Service, vol. IV, pp. 5-6. Des Moines, 1893.) Eruptive rocks in northwestern. Iowa doscribed.

Keyes, Charles R. An Old Volcanic Eruption in Iowa. (Science, vol. XXI, p. 132. New York, 1893.)

Keyes, Charles R. Age of Certain Sandstones near Iowa City. (Proc. Iowa Acad. Sci., 1890-1891, p. 25. Des Moines, 1892.) Owing to the recent discovery of fossils in the sandstones near Iowa City the suggestion is made that their age may be Kinderhook (lower Carboniferous) instead of upper Coal Measures as have been heretofore regarded.

Keyes, Charles R. Aluminum in Iowa. (Proc. Iowa Acad. Sci., 1890-1891, pp. 29-30. Des Moines, 1892.) Announcement of the establishment of a plant for the manufacture of aluminum in Franklin county.

Keyes, Charles R. American Species of Polyphemopsis. (Proc. Acad. Nat. Sci., Phila.; 1889, pp. 299-302. Philadelphia, 1889.) A revision of the species that have been referred to this group of gasteropods.

Keyes, Charles R. An Annotated Catalogue of the Mollusca of Iowa. (Bul. Essex Inst., vol. XX. Salem, 1889.) In addition to notes on the live mollusca of the State numerous references are made to the species 
Keyes, Charles R.-Continued.

collected in the loess; and a list of these species known to occur within the limits of the State is appended.

Keyes, Charles R. Attachment of Platyceras to Fossil Crinoids. (Am. Naturalist, vol. XXII, p. 924. Philadelphia, 1888.) A preliminary synopsis of the intimate associations of the two organisms.

Keyes, Charles R. Brick and Other Clays of Des Moines. (Proc. Iowa Acad. Sci., 1890-1891, p. 29. Des Moines, 1892.) A brief statement of the clay industries at Des Moines.

Keyes, Charles R. Carboniferous Echinodermata of the Mississippi Basin. (Am. Jour. Sei., (3), vol. XXXIII, pp. 186-193. New Haven, 1889.) This is a brief description of the lower Carboniferous rocks of the Mississippi basin, with suggestions as to the geological classification as indicated by crinoidal remains. A synopsis of the genera and the distribution of the species in the various formations given; also a sketch of the evolution of the crinoids during this time.

Keyes, Charles R. . Certain Forms of Straparollus from Southeastern Iowa. (Am. Geologist, vol. V, pp. 193197. Minneapolis, 1890.) The generic characters of Straparollus and Euomphalus discussed and of various species found at Burlington considered.

Keyes, Charles R. Classification of the Crinoidea. (Am. Naturalist, vol. XXIII, p. 153. Philadelphia, 1889.) A few remarks on the classification of the Crinoids and the changes necessitated by the discovery of the ventral structure of Taxocrinus (from the Kinhook, near Marshalltown, Iowa).

Keyes, Charles R. Classification of the Lower Carboniferous Rocks of the Mississippi Valley. (Washing- 
Keyes, Charles R.-Continued.

ton: Judd and Detweiller, printers, pp. 1-24, 1 plate. 1892.) Sections and details of some of the lower Carboniferous rocks in southeastern Iowa described; with allusions to the Coal Measures of the central part of the State.

Keyes, Charles R. Coal Measures of Central Iowa, and Particularly in the Vicinity of Des Moines. (Am. Geologist, vol. II, pp. 396-404. Minneapolis, 1888.) A sketch, accompanied by sections of the geological formations near Des Moines, with references to the fossils in the middle Coal Measures. Incidental reference to the eastern extension of the Cretaceous in central Iowa.

Keyes, Charles R. Contribution to the Fauna of the Lower Coal Measures of Central Iowa. (Proc. Iowa Acad. Sci., 1890-1891, pp. 22-23. Des Moines, 1892.) Description and notes on three species which, however, were previously described as new in the Proc. Acad. Nat. Sci., Phila., 1888.

Keyes, Charles R. Distribution of Certain Loess Fossils. (Am. Geologist, vol. VI, p. 119. 1890.) Remarks on the geographic range of certain of the loess fossils found in Iowa, and the adjoining parts of the neighboring states.

Keyes, Charles R. Description of Two New Fossils from the Devonian of Iowa. (Proc. Acad. Nat. Sci., Phila., pp. 247-248. Philadelphia, 1888.)

Keyes, Charles R. Eastern Extension of the Cretaceous in Iowa. (Proc. Iowa Acad. Sci., 1890-1891, p. 21. Des Moines, 1892.) Announcement of the discovery of certain Cretaceous fossils in the drift near Des 


\section{Keyes, Charles R.-Continued.}

Moines; and remarks on the probable eastern limits of the Cretacous rocks in the State.

Keyes, Charles R. Fauna of the Lower Coal Measures of Central Iowa. (Proc. Acad. Nat. Sci., Phila., 1888, pp. 231-247. Philadelphia, 1888.) Short account of the geological formations, with notes on the fossils; three species described as new.

Keyes, Charles R. Fossil Faunas in Central Iowa. (Proc. Acad. Nat. Sci., Phila., pp. 242-265. Philadelphia, 1891.) The biological relations of the fossils summarized; a general section of the rocks of the region and a list of the fossils found in the middle Coal Measures given; together with notes and bibliographic references to many of the forms found in the rocks near Des Moines. A synoptical table of the genera and species thus far recognized is appended.

Keyes, Charles R. Geological Structure and Relations of the Coal-bearing Strata of Central Iowa. (Proc. Iowa Acad. Sci., 1890-1891, pp. 27-28. Des Moines, 1892.) A summary of observations made along the Des Moines river, chiefly in the vicinity of Des Moines.

Keyes, Charles R. Iowa Coal Beds. (Coal Trade Journal, vol. XXXII, p. 133.' March 1, 1893.)

Keyes, Charles R. Iowa's Gypsum Deposits. (Mon. Rev. Iowa Weather and Crop Service, vol. IV, No. 3, pp. 2-4. Des Moines, 1893.) The geology of the gypsum region described with special reference to the amount and availability of the gypsum deposits of the State. 
Keyes, Charles R. Iowa Mineralogical Notes. (Proc. Iowa Acad. Sci., vol. I, pt. iii, pp. 19-22, 6 figures. Des Moines, 1893.) A description of certain recent finds of minerals in the State. Some unusually perfect crystals of pyrite are figured. The Keokuk Millerites are described in detail. Announcement of the presence of eruptive rocks in northwestern Iowa is also made.

Keyes, Charles R. Lower Carbonic Gasteropoda from Burlington, Iowa. (Proc. Acad. Nat. Sci., Phila., 1889, pp. 283-298. 1889.) An annotated list of the species of gasteropods found in the Kinderhook beds and Burlington limestone at Burlington, Iowa; with . remarks on the rocks in the vicinity.

Keyes, Charles R. Natural Gas and Oil in Iowa. (Proc. Iowa Acad. Sci., vol. I, pt. iii, pp. 15-18, 3 figures. Des Moines, 1893.) A statement of the various conditions necessary for a successful flow of natural gas and mineral oil and an application of the principles involved to Iowa.

Keyes, Chaṛles R. "Nickel Ore" from Iowa. (Eng. and Mining Journal, vol. LIV, p. 634. New York, 1892.) A statement in regard to the recent finds of the sulphide of nickel, or millerite, from Keokuk.

Keyes, Charles R. Note on the Distribution of Helicina Occulta. (The Nautilus, vol. III, pp. 18-19. Philadelphia, 1889.) Notes on the distribution of these fossil forms recently found living in Iowa.

Keyes, Charles R. Notes on the Redrock Sandstone. (Proc. Iowa Acad. Sci., 1890-1891, pp. 26-27. . Des Moines, 1892.) Preliminary references to the stratigraphical relations of an extensive sandstone formation in Marion county. 
Keyes, Charles R. On Some Fossils from the Lower Coal Measures at Des Moines, Iowa. (American Geologist, vol. II, pp. 24-28. Minneapolis, 1888.) A brief account of the relations of the coal horizons; with a list of 54 species of invertebrates and 2 of fishes found at Des Moines. The biological relations of the forms also receive notice.

Keyes, Charles R. On the Attachment of Platycerata to Palæocrinoids; and its Effects in Modifying the Form of the Shell. (Proc. Am. Philosophical Soc., vol. XXV, pp. 231-248, 1 plate. Philadelphia, 1888.) A statement of the cases heretofore observed and opinions concerning the sedentary habits of Platyceras. There is also given a brief historical review, with remarks on the known examples. Detailed descriptions of numerous specimens recently found in which the gasteropods are attached to various species of crinoids; together with a list of the species of Platyceras which have been found attached are given. Four species are described as new.

Keyes, Charles R. On the Fauna of the Lower Coal Measures of Central Iowa. (Proc. Acad. Nat. Sci., Phila., 1888, pp. 231-247. Philadelphia, 1888.) A brief sketch of the geological formations together with notes on many of the fossils occurring in the rocks of the region. Three species are figured and deseribed as new.

Keyes, Charles R. Preliminary Note on the Sedentary Habits of Platyceras. (Proc. Iowa Acad. Sci., 18901891, p. 24. Des Moines, 1892.) A preliminary account of the attachment of gasteropods to crinoids.

[Keyes, Charles R.] Proposed Economical Geological Survey of Iowa. (Pamphlet, 8 pp. Des Moines, 
Keyes, Charles R.-Continued.

1891.) A statement of the need of the Geological Survey of the state and of the various lines of work which especially require investigation. Comparisons with other states are made; and an outline of how the work should be conducted given. Portions appeared in various newspapers throughout the state.

Keyes, Charles R. Redrock Sandstone of Marion County, Iowa. (Am. Jour. Sci., (3), vol. XII, pp. 273-276. New Haven, 1891.) A description with section of a thick sandstone formation exposed on the Des Moines river in Marion county, showing a remarkable unconformity in the lower Coal Measures. Extension of the sand-rock is pointed out and the opinions regarding its age considered.

Keyes, Charles R. The Iowa Coal Beds. (Mon. Rev. Iowa Weather and Crop Service, vol. IV, No. 1, pp. 3-5. Des Moines, 1893.) The general geology, product and availability of the coal deposits of Iowa described.

Keyes, Charles R. Sedentary Habits of Platyceras. (Am. Jour. Sci., (3), vol. XXXVI, pp. 269-272. New Haven, 1888.) Notes on the habits of various species found in Iowa, especially those attached to crinoids.

Keyes, Charles R. Soleniscus: its Generic Characters and Relations. (Am. Naturalist, vol. XXIII, pp. 420-429, 1 plate. Philadelphia, 1889.) A description of the generic characters of the group; and several of the species belonging to the section figured from Iowa.

Keyes, Charles R. Sphærodoma: a Genus of Fossil Gasteropods. (Proc. Acad. Nat. Sci., Phila., 1889, pp. 303-309. Philadelphia, 1889.) A revision of the species formerly referred to Macrochilus; part of the 
Keyes, Charles R.-Continued.

species placed under Soleniscus and others to the new genus Sphærodoma.

Keyes, Charles R. Stratigraphy of the Carboniferous in Central Iowa. (Bul. Geol. Soc. America, vol. II, pp. 277-292, 2 plates. 1891.) A full description of the various sections exposed along the Des Moines river in the central part of the state, with special reference to the lithological characters of the strata, and the stratigraphical relations of various beds. Several marked unconformities are described and illustrated and the leading faunal aspects of the region tabulated.

Keyes, Charles R. Surface Geology of Burlington, Iowa. (Am. Naturalist, vol. XXII, p. $1049-1054,2$ plates. Philadelphia, 1888.) A sketch of the topography and surface geology of the district, with topographical map and cross sections.

Keyes, Charles R. Synopsis of American Carbonic Calyptræidæ. (Proc. Acad. Nat. Sci., Phila., 1890, pp. 150-181. Philadelphia, 1890.) A full description of the generic characters and relations of the genus Capulus found in the Carboniferous rocks of America. Also a tabular statement of the association of crinoids and gasteropods. The stratigraphical reference of all species found in the American Carboniferous to their proper horizons. All the species are described in full, with bibliographic references. The memoir is illustrated by a plate of 22 figures.

Keyes, Charles R. The Occurrence of Natural Gas in in Iowa ; and its Probable Future. (Mon. Rev. Iowa Weather and Crop Service, vol. III, No. 12, pp. 3-4. Des Moines, 1892.) A general account of the conditions necessary for a successful flow of oil and gas, 
Keyes, Charles R.-Continued.

with an account of how these conditions are satisfied within the limits of Iowa so far as is known.

Keyes, Charles R. The Platyceras Group of Palæozoic Gasteropods. (Am. Geologist, vol. X, pp. 273-277. Minneapolis, . 1892.) A revision of the group with special reference to the forms from Iowa.

Keyes, Charles R. The Principal Mississippian Section. (Bul. Geol. Soc. America, vol. III, pp. 283-300, 1 plate. 1892.). The leading section along the Mississippi river, a historical consideration of the various terms applied to rocks and a detailed description of the different formations are given. A classification of the lower Mississippian series is proposed in accordance with the observations recently made.

Keyes, Charles R. Variation Exhibited by a Carbonic Gasteropod. (Am. Geologist, vol. III, pp. 329-333. Minneapolis, 1889.) Sketch of the great variation shown in a single species from the Keokuk limestone. Outlines of specimens from Keokuk are given.

Keyes, Charles R., and R. Ellsworth Call. On a Quaternary Section Eight Miles Southeast of Des Moines, Iowa. (Proc. Iowa Acad. Sei., 1890-1891, p. 30. Des Moines, 1893.) Description of a section near the terminal moraine in the vicinity of Des Moines.

Kinderhook Beds.

Age of Certain Sandstones near Iowa City. C. R: Keyes. (Proc. Iowa Acad. Sci., 1890-1891, 26. 1892.) Owing to the recent discovery of fossils in the sandstones near Iowa City the suggestion is made that their age may be Kinderhook (lower Carboniferous) instead of upper Coal Measures as have been heretofore regarded. 
Kinderhook Beds.-Continued.

Attachment of Platyceras to Palæocrinoids. C. R.

Keyes. (Proc. Am. Philos. Soc., XXV, 231-248. 1888.) Descriptions of examples; and four new species of gasteropods.

Brachiopods from various localities in Iowa. J. Hall. (Nat. Hist. New York, Pal., VIII, 1-367. 1892.)

Certain Forms of Straparollus from Southeastern Iowa. C. R. Keyes. (Am. Geologist, V, 193-197. 1890.)

Certain sandstones of Muscatine county referred to the Devonian instead of the Lower Carboniferous. S. Calvin. (Am. Geologist, III, 25-46. 1889.)

Classification of crinoids. C. R. Keyes. (Am. Naturalist, XXIII, 153. 1889.)

Classification of the Lower Carboniferous Rocks in the Mississippi Valley. C. R. Keyes. (Washington : Judd and Detweiller, printers, 1-24. 1892.) Sections and details of the rocks in southeastern Iowa. Description of new species of crinoids. A. H. Worthen. (Illinois State Mus. Nat. Hist., Bul. No. 1, 1-39. 1882.)

Description of new species of cephalopods. D.D. Owen. (Rep. Geol. Sur. Wis., Iowa and Minn., App., art. i, 581. 1852.)

Description of new species of echinoderms. S. A. Miller and. W. F. E. Gurley. (Pamphlet, 59 pp. 1890.)

Description of new species of fossils. F. B. Meek and A. H. Worthen. (Geol. Sur. Illinois, III, 289-565. 1868:)

Description of new species of fossils from Iowa rocks. F. B. Meek and A. H. Worthen. (Geol. Sur. Illinois, II, 143-411. 1866.) 
Kinderhook Beds.-Continued.

Description of new species of fossils. G. A. White. (Proc. Bost. Soc. Nat. Hist. , IX, 8-33. 1865.)

Description. of fossil fishes. O. H. St. John and A. H.

Worthen. (Geol. Sur. Illinois, VII; 53-264. 1883.) Description of fossils. James Hall. (Geol. Iowa, I, 517-523. 1858.)

Discovery of the Ventral Structure of Taxocrinus and Haplocrinus and Consequent Modification in the Classification of the Crinoidea. C. Wachsmuth and F. Springer. (Proc. Acad. Nat. Sci., Phila., 1888, 337-363. 1888.) Recent discoveries at Marshalltown described.

Gasteropods at Burlington, Iowa. C. R. Keyes. (Proc. Acad. Nat. Sci., Phila., 283-298. 1889.) An annotated list.

Gasteropods from Iowa. J. Hall. (Nat. Hist. New York, Pal., V, pt. ii. 1879.) A number of references to fossils from Iowa.

General description. C. A. White. (Geol. Iowa, I, 191-201. 1870.) A rather detailed account with sections and illustrations of the general character of the formation and its fossils.

General description of the characters of the "Chemung." J. Hall. (Geol. Iowa, I, 91. .. 1858.)

In Des Moines county. A. H. Worthen. (Geol. Iowa, I, 205-206. 1858.)

In Franklin county. C. A. White. (Geol. Iowa, II, 240. 1870.)

In Humboldt county. C. A. White. (Geol. Iowa,.II, 244. 1870.)

- In Lee county. A. H. Worthen. (Geol. Iowa, I, 196. 1858.) 
Kinderhook Beds.-Continued.

In Washington county. A. H. Worthen. (Geol. Iowa, I, 245-246. 1858.)

Marshall Group: A Memoir on its Geological Position, Characters and Equivalencies in the United States. A. Winchell. (Proc. Am. Phil. Soc., XI, 57-83. 1869.)

New Bryozoans. E. O. Ulrich. (Geol. Sur. Illinois, VIII, 283-688. 1890.)

New species of Brachiopods from Burlington. A. Winchell. (Proc. Acad. Nat. Sci., Phila., XVII, 109-133. 1865)

New species of crinoids from Marshall county: C. Wachsmuth and F. Springer. (Geol. Surv. Illinois, VIII, 157-251. 1890.)

New species of fossils from Iowa. C. A. White. (Twelfth Ann. Rep. U. S. Geol. and Geog. Surv. Terr., 155-171. 1883.)

New species of fossils from Iowa. C. A. White: (Rep. Geog. and Geol. Expl. and Surv. w. 100 Merid., IV, 1-219. 187.5.)

New species of fossils. C. A. White. (Proc. Acad. Nat. Sci., Phila., XXVIII, 27-34. 1877.)

Of northeastern Iowa. W. J. MrcGee. (U. S. Geol. Sur., 11th Ann. Rep., 313. 1892.)

Principal Mississippian Section. C. R. Keyes. (Bul. Geol. Soc. America, III, 283-300. 1892.) The recent investigations along the Mississippi river and the stratigraphical details described, with a proposed new classification of the lower Carboniferous rocks in the Mississippi basin.

Remarkable Fauna at the Base of the Burlington Limestone in Northeastern Missouri. C. R. Keyes. (Am. Jour. Sci., (3), XLIV, 247-252. 1892.) 
Kinderhook Beds.-Continued.

Synopsis of the American Carbonic Calyptræidæ. C. R. Keyes. (Proc. Acad. Nat. Sci:, Phila., pp. 150181. 1890.) Descriptions of all the species known. Kossuth County.

Analyses of peat. Rush Emery. (Geol: Iowa, II, 399. 1870.)

General description. C. A. White. (Geol. Iowa; II, 245. 1870.) The surface characters briefly described.

Lakes.

General remarks. C. A. White. '(Geol. Iowa, I, 7078. 1870.) The principal lakes described briefly ; also explanation of the origin of "walled" lakes.

In Iowa. C. A. White. (Second Ann. Rep. State Geologist, 151-163. 1868.)

Lakes of Iowa, Past and Present. C. A. White. (Second Ann. Rep. State Geologist, 151-163. 1868.)

Lakes of Iowa, Past and Present: C. A. White. (Am. Naturalist, II, 143-155. 1868.)

Megalonyx found in Mills county. J. E. Todd. (Proc. Am. As. Ad. Sci., XXXVII, 202-203. 1889.)

\section{Lamellibranchs.}

Description of new species from the Iowa lower Carboniferous. F. B. Meek and A.H.Worthen. (Geol. Sur. Illinois, III, 289-565. 1868.)

Fossil Faunas in Central Iowa. C. R. Keyes. (Proc. Acad. Nat. Sci., Phila., 242-265. 1891.) Notes and bibliographic references of the species found in the lower Coal Measures in the central part of the state.

From eastern Nebraska. F. B. Meek. (Final Report U. S. Geol. Sur. Nebraska, pt. ii, 83-245. 1872.) 
Lamellibranchs.-Continued.

New Conocardium from the Iowa Devonian. C. R. Keyes. (Proc. Iowa Acad. Sci., 1890-1891, 23-24. 1892.) Description of Conocardium altum, regarded as new.

New species from Burlington. A. Winchell. (Proc. Acad. Nat. Sci., Phila., 225. 1863.)

New species from Burlington. C. A. White and R.P. Whitfield. (Proc. Boston Soc. Nat. Hist., VIII, 289-316. 1862.)

New species from the Lower Carboniferous rocks of Iowa. A. H. Worthen and F. B. Meek. (Geol. Sur. Illinois, VI, 489-532. 1875.)

New species from the Carboniferous of Iowa. F. B. Meek and A. H. Worthen. (Proc. Acad. Nat. Sci, XII, 447-472. 1860.)

New species from the Devonian at Davenport. W. H. Barris. (Proc. Davenport Acad. Nat. Sci., II, 282-: 288. 1878.)

New species from Iowa. A. H. Worthen. (Geol. Surv. Illinois, VIII, 69-154. 1890.)

New Species of Paleozoic Fossils. S. Calvin. (Bul. Lab. Nat. Hist. State Univ. Iowa, I, 173-181. 1890.)

New species from Paleozoic rocks of Iowa. C. A. White. (Proc. Acad. Nat. Sci., Phila., XXVIII, 27-34. 1877.)

Of central Iowa. C. R: Keyes. (Proc. Acad. Nat. Sci., Phila., 231-247. 1888.)

Species mentioned from Silurian rocks of Iowa. $R$.

P. Whitfield. (Geol. Sur. Wisconsin, IV, 163-349. 1882.).

Species of Lamellibranchs from New York. J. Hall. 
Lamellibranchs.-Continued.

(Nat. Hist. New York, Pal., V, pt. i, second half. 1885.) A number of references to fossils from Iowa.

Later Cretaceous in Iowa. S. Calvin. '(Am. Geologist, I, 237. 1888.).

\section{Lead.}

Deseription of the deposits near Dubuque, the occurrence of the ore and the mode of work. J. D. Whitney. (Geol. Iowa, I, 422-468. 1858.)

In Iowa. 'C. A. White. ' (Geol. Iowa; II, 339-341. 1870.) A few general remarks on its occurrence.

In Iowa drift. C. A. White. (Geol. Iowa, I, 96. 1870.)

Mines at Dubuque. C. A. White. (Second Ann. Rep. State Geologist, 97-150. 1868.)

Ore Deposits of Southwestern Wisconsin. T. C. Chamberlin. (Geol. Sur, Wisconsin, IV, 367-568. 1882.)

References to the lead region of northeastern Iowa. J. D. Whitney. (Geol. Sur. Illinois, I, 153-207. 1866.)

\section{Lee County.}

Artesian well at Keokuk. G. H. Gordon. (Am. Geologist, IV, 237-239. 1889.)

Brecciated Character of the St. Louis Limestone. G. H. Gordon. (Am. Naturalist, XXIV, 305-313. 1890.)

Classification of the Lower Carboniferous Rocks of the Mississippi Valley. C. R. Keyes. (Washington: Judd and Detweiller, printers, 1-24. 1892:) Sections and details of the rocks in southeastern Iowa. 


\section{Lee County.-Continued.}

Description of new fossils. A. H. Worthen. (Geol. Surv. Illinois, VIII, 69-154. 1890.)

General description. A. H. Worthen. (Geol. Iowa, I, 184-198. 1858.) A rather full account of the different formations occurring in this county.

Keokuk Beds at Keokuk, Iowa. C. H. Gordon. (Proc. Iowa Acad. Sci., 1887-9, 98-100. 1890.)

Keokuk Species of Agaricocrinus. C. H. Gordon. (Am. Geologist, V, 257-261. 1890.)

Principal Mississippian Section. C. R. Keyes. (Bul. Geol. Soc. America, III, 283-300. 1892.) Sections and details of the lower Carboniferous rocks described.

Pyrite and millerite described. C. R. Keyes. (Proc. Iowa Acad. Sci., I, pt. iii, 19-22. 1893.)

Millerite. E. Haworth. (Science, VIII, 369. 1886.) New Locality for Millerite. G. R. Keyes. (Am. Geologist, XI, 126. 1893.)

New species of sponges from the Keokuk rocks. $\mathrm{E}$. O. Ulrich. (Geol. Surv. Illinois, VIII, 243-251. 1890.)

"Nickel Ore" from Iowa. C. R. Keyes. (Eng. and Mining Journal, LIV, 634. 1892.) A statement in regard to the recent finds of the sulphide of nickel, or millerite, at Keokuk.

Observations on the Genus Archimedes. J. Hall. (Proc. Am. As. Ad. Sci., 170-180. 1857.)

Observations on the Keokuk Species of Agaricocrinus. C. H. Gordon. (Proc. Iowa Acad. Sci., 1887-9, 100-101. 1890.)

Surface geology of Keokuk. G. H. Gordon. (Am. Geologist, IX, 183-190. 1892.) 
Lee County.-Continued.

Surface Geology at Keokuk. C. H. Gordon. (Report Dep. Nat. Hist. Northwestern Univ., 11-19. 1891.) Variation of a Gasteropod (from Keokuk). C. R. Keyes. (Am. Geologist, III, 329-333. 1889.)

Wood found in Keokuk limestone. C. H. Gordon. (Proc. Iowa Acad. Sci., 1887-9, 97-98. 1890.)

Lesley, J. P. Dictionary of the Fossils of Pennsylvania. (Geol. Sur. Pennsylvania, Rep. P4, vols. I-III, pp. 11283. Harrisburg, 1890.) Numerous reproductions of figures of Iowa fossils.

Leidy, Joseph. Fossil Remains of a Caribou. (Proc. Acad. Nat. Sci., Phila., vol. XXXI, pp. 32-33. Philadelphia. 1879.) Announcement of Rangifer caribou from the Loess and Cervus muscatinensis, supposed to be extinct, from Muscatine, Iowa.

\section{Lime.}

Hydraulic. C. A. White, (Geol. Iowa, II, 318-322. 1870.) Various limestones which possess hydraulic properties discussed.

Hydraulic, materials for. J. D. Whitney. (Geol. Iowa, I, 392. 1858.)

Quick-lime. C. A. White. (Geol. Iowa, II, 316-318. 1870.) Brief mention of various limestones from which quick-lime may be made.

\section{Lime Creek.}

General Preliminary Description of the Devonian Rocks of Iowa; which Constitutes a Typical Section of the Devonian Formation of the Interior Continental Area of North America. C. L.Webster. (Am. Naturalist, XXIII, 229-243. 1889.)

\section{Linn County.}

Analysis of a Meteorite. J. Torrey and E. H. Barbour. (Am. Geologist, VIII, 65. 1891.) 
Linn County.-Continued.

Catalogue of the Recorded Meteorites. O. W. Huntington. (Proc. Am. Acad. Art. and Sei., XV, 37110. 1887.)

Chemical analyses of a meteoric fall. C. U. Sheppard. (Am. Jour. Sci., (2), VI, 402-417. 1848.)

Cretaceous fossils in the drift. [S. Calvin.] (Am. Geologist, I, 237. 1888.)

Fall of the Meteoric Stones. C. U. Sheppard. Am. Jour. Sci., (2), IV, 288-289. 1847.)

Geological notes. J. D. Whitney. (Geol. Iowa, I, 260266. 1858.)

Local Geology of Davenport and Vicinity. W. H. Barris.

(Proc. Davenport Acad. Nat. Sci., II, 261-269. 1877.) Localities of Minerals. E. S. Dana. ('lext Book of Mineralogy, 15th ed., App. C., Iowa, 445. 1889.) Loess.

At Burlington. C.R. Keyes. (Am. Naturalist, XXII, 1049-1054. 1888.)

At Keokuk, Iowa. C. H. Gordon. (Rep. Dep. Nat. Hist. Northwestern Univ., 11-19. 1891.)

A.t Muscatine. F. M. Witter. (Proc. Iowa Acad. Sci., 1875-80, 16. 1880.)

Charcoal Streak in the Loess. J. E. Todd. (Proc. Iowa Acad., Sci., 1875-1880, 21. 1880.)

Complete Series of Superficial Geological Formations in Northeastern Iowa. W. J. McGee. (Proc. Am. As. Ad. Sci., XXVII, 198-231. 1878.)

Deseription of the deposits near Davenport. W. H. Pratt. (Proc. Davenport Acad. Nat. Sci., I, 96-99. 1876.)

Distribution of fossils. C. R. Keyes. (Am. Geologist, VI, 119. 1890.) 
Loess.-Continued.

Driftless area of the upper Mississippi. T. C. Chamlin and R. D. Salisbury. (U. S. Geol. Sur., 6th Ann. Rep., 199-322. 1886.)

Fossils collected in the state of Iowa. C. R. Keyes. (Bul. Essex Inst., XX. 1889.)

Fossils of the Iowa Loess. R. E. Call. (Am. Naturalist, $\mathrm{XV}, 585-586 . \quad$ 1881.)

Fossils at Iowa City. B. Shimek. (Am. Geologist, I, 149-152. 1888.)

In central Iowa. R. E. Call. (Am. Naturalist, XV, 782-784. 1881.)

Its distribution in eastern Iowa. W. J. McGee. (Bul. Phil. Soc. Washington, VI, 93-97. 1883.)

Its fossils. B. Shimek. (Bul. Lab. Nat. Hist. State Univ. Iowa, I, 200-214. 1890.)

Loess and Associated Deposits of Des Moines. W. J. McGee and R. E. Call. (Am. Jour. Sci., (3), XXIV, 202-223. 1882.)

Loess and its fossils. B. Shimek. (Bul. Lab. Nat. Hist. State Univ., II, 88-98. 1890.)

Loess and its Soils. J. E. Todd. (Proc. Iowa Hort. Soc., XVII, 263-270. 1882.)

Loess in Central Iowa. R. E. Call. (Am. Naturalist, $\mathrm{XV}, 782-784$. 1881.)

Loess of North America. R. E. Call. (Am. Naturalist, XVI, 369-381. 1882.)

Notes on the Geology of Johnson County. C. I.

Webster. (Am. Naturalist, XXII, 408-419. 1888.) Notes on the Geology of a Part of the Mississippi Valley. W. J. McGee. (Geological Magazine, (2), VI, 412-420 and 353-362. 1879.) 
Loess.-Continued.

Notice of Arrow Points from the Loess in the City of Muscatine. F. M. Witter. (Proc. Iowa Acad. Sci., 1890-1891, 66-68. 1892.)

Observations upon the Loess. F. MI. Witter. (Proc. Iowa Acad. Sci., 1887-1889, 45. 1890.)

Of eastern Iowa. W. J. McGee. (Pamphlet, 1-14. Ft. Dodge, 1884.)

Of northeastern Iowa. W. J. McGee. (Eleventh Ann. Rep. U. S. Geol. Sur., 435-472. 1892.)

On a Quaternary Section Eight Miles Southeast of Des Moines, Iowa. C. R. Keyes and R. E. Call. (Proc. Iowa Acad. Sci., 1890-1891, 30. 1892.) Description of a section near the terminal moraine in the vicinity of Des Moines.

Of North America. R. E. Call. (Am. Naturalist, XVI, 369-381. 1882.)

On the Relation of Loess to Drift in Southwestern

' Iowa. J. E. Todd. (Proc. Iowa Acad. Sci., 18751880, 19. 1880.)

On the Roots and Root-marks Found in the Loess. J. E. Todd. (Proc. Iowa Acad. Sci., 1875-80, 17. 1880.)

Recent Wind Action upon the Loess. J. E. Todd. (Proc. Iowa Acad. Sci., 1875-1880, 21. 1880.)

Relative Position of Forest Beds and Associated Drift Formations in Northeastern Iowa. W. J. McGee. (Am. Jour. Sci., (3), XV, 339-341. 1878.)

Richthofen's Theory of the Loess in the Light of the Deposits of the Missouri. J. E. Todd. (Proc. Am. As. Ad. Sci., XXVII, 231-239. 1878.)

Surface geology of Keokuk. C. H. Gordon. (Am. Geologist, IX, 183-190. 1892.) 
Loess.-Continued.

Section of the Bluff at Sixth Street, Davenport. W. H. Pratt. (Proc. Davenport Acad. Nat. Sci., III, 127-129. 1881.)

Lower Carbonic Gasteropods from Burlington, Iowa. C.

R. Keyes. (Proc. Acad. Nat. Sci., Phila., 283-298. 1889.)

\section{Louisa County.}

Gas wells near Letts, Iowa. F. M. Witter. (Am. Geologist, IX, 319-321. 1892.)

Gas wells near Letts, Iowa. F. M. Witter. (Proc. Iowa Acad. Sci., 1890-1891, 68-70. 1892.) Gas reported as being found in a number of places near Letts, in Louisa county, and furnishing supplies to a number of families.

\section{Lucas County.}

Its geology. O. H. St. John. (Geol. Iowa, II, 77-95. 1870.) A full account of the geological formation as exposed in the county.

\section{Lyon County.}

General description. C. A. White. (Geol. Iowa, II, 226-229. 1870.) Brief mention of the surface features.

\section{Madison County.}

Analyses of coal. Rush Emery. (Geol. Iowa, II, 386-387. 1870.)

General geological description. C. A. White: (Geol. Iowa, I, 305-316. 1870.) A rather full account of the surface features, geology and economic resources.

Short notes on the geology. C. A. White. (First Ann. Rep. State Geologist, 70-73. 1868.)

Strata between Ford and Winterset. J. L. Tilton. (Proc. Iowa Acad. Sci., I, pt. iii, pp. 26-27. 1893.) 
Magnesian Limestone (Lower).

Chemical analyses. J. D. Whitney. (Geol. Iowa, I, 332-337. 1858.)

Description of New Trilobites. D. D. Owen. (Rep. Geol. Sur. Wis., Iowa and Minn., App., art. i, 573577. 1852.)

Description of the rocks in northeastern Iowa. D. D. Owen. (Geol. Sur. Wis., Iowa and Minn., 58-69. 1852.) An account of the lithological and geological features, its range, mineral contents and palæontology.

Fossils from Northeastern Iowa. S. Calvin. (Am. Geologist, X, 144-148. 1892.)

General description. C. A. White. (Geol. Iowa, I, 172-174. 1870.) A brief statement of its characters, economic value and fossils.

\section{Mahaska County.}

Analyses of coal. Rush Emery. (Geol. Iowa, II, 370375. 1870.)

Brief allusion to its geology. C. A. White. (Second Ann. Rep. State Geologist, 91-93. 1868.)

General description. C. A. White. (Geol. Iowa, II, 265-267. 1870.) Brief general description of the geology.

Mammals.

Ovibos cavifrons from the Loess of Iowa, found at Council Bluffs. W. J. McGee. (Am. Jour. Sci., (3), XXXIV, 217-220. 1887.)

Megalonyx found in Mills county. J. E. Todd. (Proc. Am. As. Ad. Sci., XXXVII, 202-203. 1889.)

Manual of Geology. J. D. Dana. (3rd ed., pp. 1-911. 1880.) 
Maps.

Diagrammatic Map of the Drift Currents Adjacent to the Driftless Area. T. C. Chamberlin and R. D. Salisbury. (U. S. Geol. Sur., 6th Ann. Rep.; plate xxix. Washington, 1886.)

General map of the Drift of Northeastern United States. T. C. Chamberlin and R. D. Salisbury. (U. S. Geol. Sur., 6th Ann. Rep., plate xxiii. Washington, 1886.)

Geological map of Iowa. C. A. White. (Geol. Iowa, II. Des Moines, 1870.) A sketch-map showing the general geological formations.

Geological map of Iowa. D. D. Owen. (Rep. Geol. Sur. Wis., Iowa and Minn. 1852.) A large colored map showing the geological formations in the Mississippi valley.

Geological map of eastern Iowa. James Hall. (Geol. Iowa, I. 1858.) A colored sectional map showing the different geological formations in the eastern part of the state.

Geological map of the state of Iowa. C. A. White. (Geol. Iowa, vol. II. 1870.)

Geological map model of Iowa. C. A. White. (Geol. Iowa, I. 1870.)

Geological map of the lead region in the states of Wisconsin, Illinois and Iowa. J. D. Whitney. (Geol. Sur. Wisconsin, I. 1862.)

Geological map of the eastern half of the state of Iowa. J. Hall, J. D. Whitney and A.H. Worthen. (Geol. Iowa, I, 146. 1858.)

- Geological Section from the Mouth of Rock River through the Blue Mounds to the Wisconsin River, in Connection with a Geological Chart of Part of 
Maps.-Continued.

Iowa, Wisconsin and Illinois. (Report of Geological Explorations of Parts of Iowa, Wisconsin and Illinois, made in the autumn of the year 1839, Plate iii. [Washington], 1844.)

Geological Chart of Part of Iowa, Wisconsin and Illinois. D. D. Owen. (Report of a Geological Exploration of Part of Iowa, Wisconsin and Illinois, made in the autumn of the year 1839. [Washington], 1844.)

Keokuk and vicinity (sketch-map). C. H. Gordon. (Am. Geologist, IX, 183-190. 1892.)

List of geological maps of Iowa. J. Marcou and J. B. Marcou. (Bul. U. S. Geol. Sur. No. 7, 89-101. 1884.)

Map of the glacial strix of the eastern United States. T. C. Chamberlin. (U. S. Geol. Sur., 7th Ann. Rep., plate vii. Washington, 1888.)

Map of Wisconsin and Adjoining Portions of Michigan, Illinois, Iowa and Minnesota, showing geological structure, positions of the two principal mineral districts, etc., scale 20 miles to 1 inch. R. D. Irving. (Trans. Am. Inst. Mining Engrs., VIII, 506. 1880.)

Mapotica Geologica Americana. Jules Marcou and John Belknap Marcou. (Bul. U.S. Geol. Sur. No. 7, pp. 89-101. 1884.)

Provisional Geological Map of Part of the Chippewa Land District of Wisconsin, with Part of Iowa, and of Minnesota Territory to Illustrate the Report of a Geological Reconnaissance made in 1847. (Report of a Geological Reconnaissance of the Chippewa land district of Wisconsin; and incidentally 
Maps._Continued.

of a portion of the Kickapoo country, and of a part of Iowa and of the Minnesota Territory. [Washington, 1849.])

Quaternary Map of the Driftless Area and Environs. T. C. Chamberlin and R. D. Salisbury. (U. S. Geol. Sur., 6th Ann. Rep., plate xxvii. Washington, 1886.)

Sketch-map of Worth, Mitchell, Cerro Gordo and Floyd counties, showing distribution of the Rockford shales. C. Li Webster. (Proc. Davenport Acad. Nat. Sci., V. 1887.)

Sketch-Map of the State of Iowa. C. A. White. (Geol. Mag., VIII; 222. London, 1871.)

Topographical sketch-map of Burlington and vicinity. C. R. Keyes. (Am. Naturalist, XXII. 1888.)

\section{Maquoketa Shales.}

General description. C. A. White. (Geol. Iowa, I, 180-182. 1870.) The general characters, economic value and geological age of these rocks in Iowa described, with brief references to their sections and the fossils contained.

Of northeastern Iowa. W. J. McGee. (Eleventh Ann. Rep. U. S. Geol. Sur., 326-327. 1892.)

Section in Iowa. J. F. James. (Proc. Am. As. Ad. Sci., XXXVII, 250-251. 1890.)

Their correlation. J. F. James. (Am. Geologist, V, 335-356. 1890.)

"Marble."

In Marshall county. C. A. White. (Geol. Iowa, II, 303. 1870.)

"Iowa City and Birds' Eye." C. A. White. (Geol. Iowa, II, 316. 1870.) Occurrence in Johnson county. 
Marcou, Jules. Le terrane cretace des environs de Sioux Gity. (Bul. Soc. géol. de France, (2), t. XXIV, p. 56. Paris, 1866.) Describes the Cretaceous rocks below Sioux City.

Marcou, Jules. Une Recomnaissance géologique au Nebraska. (Bul. Soc. géol. de France, (2), t. XXI, p. 137. Paris, 1864.) A number of incidental notes relating to the geology of western Iowa are given.

Marcou, Jules, and John Belknap Marcou. Mapotica Geologica Americana. (Bul. U. S. Geol. Sur., No. 7, pp. 89-101. Washington, 1884.) List of geological maps of Iowa.

Marshall County.

Attachment of Platyceras to Palreocrinoids. C. R. Keyes. (Proc. Am. Philos. Soc., XXV, 231-248. 1888.)

Classification of the Crinoids. C. R. Keyes. (Am. Naturalist, XXIII, 153. 1889.)

Description of new species of Echinoderms. S. A. Miller and W. F. E. Gurley. (Pamphlet, $59 \mathrm{pp}$. 1890.)

Discovery of the Ventral Structure of Taxocrinus and Haplocrinus and Consequent Modifications in the Classification of the Crinoidea. C. Wachsmuth and F. Springer. (Proc. Acad. Nat. Sci, , Phila., 1888, 337-363. 1888.) Recent discoveries at Marshalltown.

General reference. C. A. White. (Geol. Iowa, II, 260. 1870.)

Geological notes. J. D. Whitney. (Geol. Iowa, I, 266-273. 1858.)

"Marble." C. A. White. (Geol. Iowa, II, 313. 1870.) New species of erinoids from the Kinderhook. C. 
Marshall County.-Continued.

Wachsmuth and F. Springer. (Geol. Surv. Illinois, VIII, 157-251. 1890.)

Reference to its geological features. C. A. White.

(Second Ann. Rep. State Geologist, 117-119. 1868.)

Marshall Group: A Memoir on its Geological Position, Characters and Equivalencies in the United States.

A. Winchell. (Proc. Am. Philosophical Soc., XI, 57-

83. 1869.)

Marion County.

Analyses of coal. Rush Emery. (Geol. Iowa, II, 364-370. 1870.)

Brief sketch of its geological features. C. A. White. (Second Ann. Rep. State Geologist, 100-108. 1868.) Description of new fossils. A. H. Worthen. (Geol. Surv. Illinois, VIII, 69-154. 1890.).

Geology. C. A. White. (Geol. Iowa, II, 263-265. 1870.) Brief account of Coal Measures in the county.

Notes on the Redrock Sandstone. C. R. Keyes. (Proc. Iowa Acad. Sc̣i., 1890-1891, 26-27. 1892.) Preliminary references to the stratigrapical relation of a thick sandstone formation in Marion county. Redrock Sandstone of Marion County; Iowa. C. R. Keyes. (Am. Jour. Sci., (3), XLI, 273-276. 1891.) A description of the formation and its unconformities.

Spontaneous Fission? in Zaphrentis: C. A. White. (Am. Jour. Sci., (3), V, 72. 1873.)

McGee, W. J. Additional Observations on Iowa Kames and Aasar. (Proc. Iowa Acad. Sci., 1875-1880, p. 25. Iowa City, 1880.) Abstract of a paper read before the Iowa Academy of Sciences, June 25, 1880. 
McGee, W. J. Description of the Quarries and Quarry Regions of Iowa. ('I'enth Census of U. S., vol. X, Report Building Stones, pp. 256-265. Washington, 1883.) A résumé of the geological formations of Iowa, with special references to the leading building stones.

McGee, W. J. Notes on the Geology of a Part of the Mississippi Valley. (Geological Magazine, (2), vol.VI, pp. 412-420 and 353-362. London, 1879.) A description of the Quaternary deposits of northeastern Iowa.

McGee, W. J. On some Iowa Kames and Aasar. (Proc. Iowa Acad. Sci., 1875-1880, p. 19. Iowa City, 1880.) Abstract of a paper read before the Iowa Academy, October 10, 1879.

McGee, W. J. On the Complete Series of Superficial Geological Formations in Northeastern Iowa. (Proe. Am. As. Ad. Sci., vol. XXVII, pp. 198-231. Salem, 1878.) A description of the surface geology of northeastern Iowa.

McGee, W. J. On the Relative Position of Forest Beds and Associated Drift Formations in Northeastern Iowa. (Am. Jour. Sci., (3), XV, pp. 339-341. New Haven, 1878.) A number of sections at Farley given, with special references to the forest bed in Dubuque county.

McGee, W. J. On the Superposition of Glacial Drift upon Residuary Clays. (Am. Jour. Séi., (3), vol. XVIII, pp. 301-303. New Haven, 1879.) A section in Delaware county described showing the relations of the two formations.

McGee, W. J. Ovibos Cavifrons from the Loess of Iowa. (Am. Jour. Sci., (3), vol. XXXIV, pp. 217-220. New Haven, 1887.) Notice of a specimen of extinct Musk ox found near Council Bluffs, and its bearing upon the nature of the climate during the deposition of the loess. 
McGee, W. J. The Drainage System and the Distribution of the Loess of Eastern Iowa. (Bul. Philosophical Soc. Washington, vol. VI, pp. 93-97. Washington, 1883.) An abstract of a general description of the drainage system.

McGee, W. J. The Drainage System and Distribution of the Loess of Eastern Iowa. (Pamphlet, pp. 1-14. Ft. Dodge, 1884.) A description of the general drainage system and topography, with explanations of the phenomena.

McGee, W. J. The Pleistocene History of Northeastern Iowa. (U. S. Geol. Sur., 11th Ann. Rep., pp. 190-577. Washington, 1893.)

Chapter $I$ is a very full description of the landscape and general topography of northeastern Iowa.

Chapter II forms a statement of the principles involved in the description of the geological history of the region, with full definitions.

Chapter III deals with a general account of the stratigraphical rocks of the state. A classification and description of the-different formations are given, with the different kinds of disturbances recognized.

Chapter IV is a detailed account of the drainage and topography of the different quaternary formations.

Chapter V treats of the post-glacial phenomena; alluvium and terraces.

Chapter VI is a detailed account of the Loess and its occurrence in different places.

Chapter VII, a description of the drift and an account of many well sections.

Chapter VIII considers the ice markings-glacial striæ and surface moldings.

Chapter IX treats of the residuary products and the history indicated by them. 
McGee, W. J.-Continued.

Chapter $\mathrm{X}$ is a general summary of the geological history as recorded in Iowa.

McGee, W. J. The Relations of Geology and Agriculture. (Trans. Iowa State Horticultural Soc., vol. XVI, pp. 227-240. 1884.) An address before the society in which the bearing of Agriculture upon Geology is fully described with special reference to Iowa.

McGee, W. J. Topographic Types of Northeastern Iowa. (Proc. Am. As. Ad. Sci., vol. XXXVII, pp. 248-249. Salem, 1890.) Abstract of more extended paper: Half a dozen distinctive types of topography recognized.

McGee, W. J., and R. Ellsworth Call. On the Loess and Associated Deposits of Des Moines. (Am. Jour. Sci., (3), vol. XXIV, pp. 202-223. New Haven, 1882.) The topographical features of the region outlined with accompanying sketch-map; the different sections of surface deposits described in detail with list of fossils and a synoptical table showing the distribution of the fossils occurring.

McWhorther, Tyler. 'Beds of Carboniferous Drift in the Bluffs of East Davenport. (Proc. Davenport Acad. Nat. Sci., vol. III, pp. 129-130. Davenport, 1882.)

\section{Medina Sandstone.}

General description of the characters. James Hall. (Geol. Iowa, I, 70-71. 1858.)

Meek, F. B. A Report on the Invertebrate Cretaceous and Tertiary Fossils of the Upper Missouri Country. (U. S. Geol. Sur. Terr., vol. IX. Washington, 1876.) A number of references to the geology at the mouth of the Big Sioux river. 
Meek, F. B. Remarks on Prof. Geinitz's Views Respecting the Upper Paleozoic Rocks and Fossils of Southeastern Nebraska. (Am. Jour. Sci., (2), vol. XLIV, pp. 170-187. New Haven, 1867.) Numerous incidental references to the geology of western Iowa.

Meek, F. B. Remarks on the Carboniferous and Cretaceous Rocks of Eastern Kansas and Nebraska, and their Relations to those of the Adjacent States, and other localities farther eastward; in connection with a Review of a Paper Recently Published on this Subject by M. Jules Marcou in the Bulletin of the Geological Society of France. (Am. Jour. Sci., (2), vol. XXXIX, pp. 159-174. New Haven, 1865.) Numerous incidental references to the geology of western Iowa.

Meek, F. B. Report on the Paleontology of Eastern Nebraska, with Remarks on the Rocks of that District. (Final Report U. S. Geol. Sur. Nebraska, pt. ii, pp. 83-245, pls. i-ix. 1872.) Numerous incidental references to the occurrence of Carboniferous fossils in Iowa.

Meek, F. B., and A. H. Worthen. Contribution to the Paleontology of Illinois and other Western States. (Proe. Acad. Nat. Sci., Phila., vol. XIX, pp. 251-275. Philadelphia, 1868.) Several new species of crinoids from Burlington described.

Meek, F. B., and A. H. Worthen. Description of Invertebrates from the Carboniferous System. (Geol. Sur. Illinois, vol. V, pp. 323-619. Springfield, 1873.) Numerous species described from Iowa rocks.

Meek, F. B., and A. H. Worthen. Description of New Carboniferous Fossils from Illinois and other Western States. (Proc. Acad. Nat. Sci., Phila., vol. XII, pp. 
Meek, F. B.-Continuel.

447-472. Philadelphia, 1860.) A few species described as new from Iowa.

Meek, F. B., and A. H. Worthen. Description of New Crinoidea and Echinoidea from the Carboniferous Rocks of the Western States; with a note on the Genus Onychaster. (Proc. Acad. Nat. Sci., Phila., vol. XXI, pp. 67-83. Philadelphia, 1869.) Many species noted from Iowa, several being described as new.

Meek, F. B., and A. H. Worthen. Description of New Invertebrates from the Carboniferous System. (Geol. Sur. Illinois, vol. II, pp. 143-411. Springfield, 1866.) Numerous species described from Iowa rocks.

Meek, F. B., and A. H. Worthen. Description of New Paleozoic Fossils from Illinois and Iowa. (Proc. Acad. Nat. Sci., Phila., vol. XIII, pp. 128-148. Philadelphia, 1861.) Numerous species are described as new.

Meek, F. B., and A. H. Worthen. Description of New Species and Genera of Fossils from the Paleozoic Rocks of the Western States. (Proc. Acad. Nat. Sci., Phila., vol. XIII, pp. 22-56. Philadelphia, 1860.) Two species described as new from Iowa.

Meek, F. B., and A. H. Worthen. Description of New Species of Crinoidea, etc., from the Palreozoic Rocks of Illinois and some of the Adjoining States. (Proc. Acad. Nat. Sci., Phila., vol. XVII, pp. 143-166. Philadelphia, 1865.) Two specirs described as new from Iowa.

Meek, F. B., and A. H. Worthen. Description of New Species of Crinoidea and Echinoidea from the Carboniferous Rocks of Illinois and other Western States. 
Meek, F. B.-Continued.

(Proc. Acad. Nat. Sci., Phila., vol. XII, pp. 378-397. Philadelphia, 1860.) Several species described as new from Iowa.

Meek, F. B., and A. H. Worthen. Notes on some Points in the Structure and Habits of Palæozoic Crinoidea. (Proc. Acad. Nat. Sci., Phila., vol. XX, pp. 323-334. Philadelphia, 1868.) The observations are based upon species obtained chiefly from Burlington.

Meek, F. B., and A. H. Worthen. Paleontology of Illinois. (Geol. Sur. Illinois, vol. III, pp. 289-565. Springfield, 1868.) Numerous species of fossils described from Iowa.

Meek, F. B., and A. H. Worthen. Remarks on some Types of Carboniferous Crinoidea, with Descriptions of New Genera and Species of the Same and of one Echinoid. (Proc. Acad. Nat. Sci., Phila., vol. XX, pp. 335-359. Philadelphia, 1868.) A number of species described as new from Iowa.

Meek, F. B., and A. H. Worthen. Remarks on the Age of the Goniatite Limestone at Rockford, Indiana, and its Relations to the Black Slate of the Western States and to Some of the Succeeding Rocks Above the Latter. (Am. Jour. Sci., (2), vol. XXXII, pp. 167-177. New Haven, 1861.) References to the correlation of the lower Garboniferous.

Meek, F. B., and A. H. Worthen. Remarks on the Blastoidea, with Descriptions of New Species. (Proc. Acad. Nat. Sci., Phila., vol. XXI, pp. 83-91. Philadelphia, 1869.) Several forms described as new from Iowa:

Meek, F. B., and A. H. Worthen. Remarks on the Genus Taxocrinus (Phillips) McCoy, 1844; and its 
Meek, F. B.-Continued.

Relations to Forbesiocrinus, Koninck and Le Hon, 1854 ; with Description of New Species. (Proc. Acad. Nat. Sci., Phila., vol: XVII, pp. 138-143. Philadelphia, 1865.) Taxocrinus gracilis described as new, from New Buffalo, Iowa.

Meek, F. B., A. H. Worthen and. Description of Invertebrates. (Geol. Sur. Illinois, vol. VI, pp. 489532, with plates. Springfield, 1875.) See A. H. Worthen and F. B. Meek, 1875.

Merrill, George P. Collection of Building and Ornamental Stones in the U. S. National Museum: Hand Book and Catalogue. (Smithsonian Inst., Ann. Report 1885-1886, pt. ii, pp. 277-648. Washington, 1889.) Brief general references to some of the Iowa building stones.

Merrill, George P. Stones for Building and Decorating. (453 pp. New York, 1891.) A number of general references to the building stones of Iowa.

\section{Meteorites.}

Analyses of the Winnebago fall. E. N. Eaton. (Am. Geologist, VIII, 385-387. 1891.)

Catalogue of the Recorded Meteorites. O. W. Huntington. (Proc. Am. Acad. Art. and Sci., New Ser., XV, 37-110. 1887.)

Fall in Linn county. C. U. Sheppard. (Am. Jour. Sci., (2), IV, 288-289. 1847.)

Report on the Linn county fall, with chemical analyses. C. U. Sheppard. (Am. Jour. Sci., (2), VI, 402-417. 1848.)

Winnebago county meteorites. Joseph Torrey, Jr., and E. H. Barbour. (Science, XV, 347. 1890.) Reference to a fragment supposed to be a piece of 
Meteorites.-Continued.

meteorite. The authors elaim it was not and base their claims on the grounds of: Too low specific gravity, absence of metals and external crust, and chemical analysis.

Middle Goal Measures. O. H. St. John.' (Geol. Iowa, I, 264-284. 1870.)

Miller, S. A. On the Synonymy of two Species of Spirifera. (Proc. Davenport Acad. Nat. Sci., vol. II, pp. 220-221. Davenport, 1878.) A change in the name of Spivifera pennata as described by Owen.

Miller, S. A., and W. F. E. Gurley. Description of some New Genera and Species of Echinodermata from the Coal Measures and Subcarboniferous Rocks of Indiana, Missouri and Iowa. (Pamphlet, 59 pp., 10 plates. Cincinnati, 1890.) Several species of crinoids described as new from the Kinderhook rocks of Marshall county.

Millerite.

Millerite. E. Haworth. (Science, VIII, 369. 1886.) Recent finds described in detail. C. R. Keyes. (Proc. Iowa Acad. Sci., I, pt. iii, 19-22. 1893.)

New Locality for Millerite. C. R. Keyes. (Am. Geologist, XI, 126. 1893.)

"Nickel Ore" from Iowa. C. R. Keyes. (Eng. and Mining Journal, LIV, p. 634. 1892.) A statement in regard to the occurrence of the sulphide of nickel from Keokuk.

Mineral Resources of the United States. A. Williams, Jr. (U. S. Geol. Sur., Statistical Papers, 813 pp. 1883.)

Mineral Resources of the United States for 1883-1884. A. Williams, Jr. (U. S. Geol. Sur., Statistical Papers, 1016 pp. 1885.) 
Mineral Resources of the United States for the Year 1885. Anon. (U. S. Geol. Sur., Statistical Papers, 516 pp. 1886.)

Mineral Resources of the United States for 1886 . D. T. Day. (U. S. Geol. Sur., Statistical Papers, 813 pp. 1887.)

Mineral Resources of the United States for 1887. D.T. Day. (U. S. Geol. Sur., Statistical Papers, 832 pp. 1888.)

Mineral Resources of the United States for 1888. D. T. Day. (U. S. Geol. Sur., Statistical Papers, 652 pp. 1890.)

Mineral Resources of the United States for 1889 and 1891. D. T. Day. (U. S. Geol. Sur., Statistical Papers, 671 pp. 1892.)

Minerals.

Aluminum in Iowa. C. R. Keyes. (Proc. Iowa Acad. Sci., 1890-1891, 29-30. 1892.) Announcement of the establishment of a plant for the manufacture of aluminum in Franklin county.

Allusions to Iowa Minerals. D. T. Day. (U. S. Geol. Sur., Statistical Papers, 652 pp. 1890.)

Analyses. Rush Emery. (Geol. Iowa, II, 352-354. 1870.)

List of useful minerals and their localities. D. T. Day.

(U. S. Geol. Sur., Statistical Papers, 652 pp. 1888.) List of useful minerals and their localities. Albert Williams, Jr. (U. S. Geol. Sur., Statistical Papers, 1016 pp. 1885.)

List of useful minerals and their localities. D.T. Day.

(U. S. Geol. Sur., Statistical Papers, 813 pp. 1887.) List of useful minerals and their localities. Albert Williams, Jr. (U. S. Geol. Sur., Statistical Papers, 813 pp. 1883.)

26 G. Rep. 
Minerals.-Continued.

List of useful minerals and their localities. D. T. Day.

(U. S. Geol. Sur., Statistical Papers, 832 pp. 1888.)

List of useful minerals and their localities. Anon.

(U. S. Geol. Sur., Statistical Papers, 516 pp. 1886.)

List of Iowa mineral localities. E. S. Dana. (Text-

Book of Mineralogy, 15th ed., Ap. C., Iowa, 445. 1889.)

Mineral resources of Iowa for 1889-1890. D. T. Day.

(U.S. Geol. Sur., Statistical. Papers, 671 pp. 1892.)

Notes on Iowa minerals. G. Hinrichs. (Second Ann.

Rep. State. Geologist, 268-279. 1868.)

References to the lead region of northeastern Iowa. J.

D. Whitney. (Geol. Sur. Illinois, I, 153-207. 1866.)

\section{Mining.}

Accounts of the various coal mines. Park C. Wilson.

(First Biennial Report State Mine Inspector, 18821883, 1-94. 1883.)

Coal mines in the state. P. C. Wilson. (Biennial Rept. State Mine Inspector, for 1880-1881. 1-165. 1882.) Accounts of the different coal mines of the state.

Coal mines of the state. P.C. Wilson: (Second Biennial Rep. State Mine Inspector, 1884-1885, 1-116. 1885.)

Coal in southeastern Iowa. Thomas Binks. (Fifth Biennial Report State. Mine Inspectors, 1890-1891. 1-51. 1891.)

Coal mines of southeastern Iowa. Thomas Binks. (Third Biennial Report State Mine Inspectors, 18861887, 1-80. 1888.)

Coal in north-central Iowa. M. C. Thomas. (Fifth 
Mining.-Continued.

Biennial Report State Mine Inspectors, 1890-1891, 95-151. 1891.)

Coal mines of central Iowa. J. A. Smith. (Third Biennial Rep. State Mine Inspectors, 1886-7, 81-112. 1888.)

Coal mines in north-central Iowa. J. A. Stout. (Third Biennial Rep. State Mine Inspectors, 1886-7, 113177. 1888.)

Coal in south-central Iowa. James Gildroy. (Fourth Biennial Report State Mine Inspectors, 1888-9, 65114. 1889.)

Coal in south-central Iowa. James Gildroy. (Fifth Biennial Report State Mine Inspectors, 1890-91, 5592, 1891.)

Coal. C. A. White. (Geol. Iowa, I, 258-263. 1870.)

Practical conclusions regarding the mining of coal in Iowa.

In north-central Iowa. J. A. Stout. (Fourth Biennial Report State Mine Inspectors, 1888-9, 115-151. 1889.)

In southeastern Iowa. Thomas Binks. (Fourth Biennial Report State Mine Inspectors, 1888-9, 1-65. 1889.)

\section{Mills County.}

Brief geological notes. C. A. White. (First Ann. Rep. State Geologist, 56-59. 1868.)

General geological description. C. A. White. (Geol. Iowa, I, 367-371. 1870.). The surface characters and geology briefly described.

Mitchell County.

Distribution of Rockford shales. C. L.Webster. (Proc. Davenport Acad. Sci., V, 100-109. 1887.) 
Mitchell County.-Continued.

Notice of the geology. J. D. Whitney. (Geol. Iowa, I, 306-311. 1858.)

\section{Monona County.}

Brief general description of the surface features. $O$.

H. St. John. (Geol. Iowa, II, 182-186. 1870.)

\section{Monroe County.}

Analyses of coal. Rush Emery. (Geol. Iowa, II, 360-364. 1870.)

Brief reference to its geology. C. A. White. (Second Ann. Rep. State Geologist, 93-94. 1868.)

General description. C. A. White. (Geol. Iowa, II, 267-268. 1870.) Reference to the general surface features.

Montgomery County.

Brief references to the geology. C. A. White. (First Ann. Rep. State Geologist, 63-65. 1868.)

Chert of the Upper Coal Measures. S. Calvin. (Am. Geologist, I, 116-117. 1888.)

General geological description. C. A. White. (Geol. Iowa, I, 362-366. 1870.) A description of the surface characters and geology, with several sections.

Muscatine County.

Devonian sandstone. S. Calvin. (Am. Geologist, III, 25-36. 1889.)

Description of the geology. J. D. Whitney. (Geol. Iowa, I, 274-277. 1858.) Brief account of the geological formations.

Fossil Remains of a Caribou. J. Leidy. (Proc. Acad. Nat. Sci., Phila., XXXI, 32-33. 1879.)

Gas Wells near Letts, Iowa. F. M. Witter. (Proc. Iowa Acad. Sci., 1890-91, 68-70. 1892.) Gas re- 
Muscatine County.-Continued.

ported as being found in a number of places near Letts, in Louisa county, and furnishing supplies to a number of families.

Loess at Muscatine. F. M. Witter. (Proc. Iowa Acad. Sci., 1875-1880, 16. 1880.)

Observations upon the Loess. F. M. Witter. (Proc. Iowa Acad. Sci., 1887-9, 45. 1890.)

Reference to coal. C. A. White. (Geol. Iowa, II, 274. 1870.) Mere mention of the occurrence of coal in the county.

Some Geological Problems. S. Calvin. (Bul. Lab. Nat. Hist. State Univ. Iowa, I, 7-18. 1888.)

\section{Natural Gas.}

Near Letts, in Louisa county. F. M. Witter. (Am. Geologist, IX, 319-321. 1892.)

Natural Gas in Iowa. R. E. Call. (Mon. Rev. Iowa Weather and Crop Service, III, 6-7. 1892.)

Occurrence of Natural Gas in Iowa; and its Probable Future. C. R. Keyes. (Mon. Rev. Iowa Weather and Crop Service, III, No. 12, 34. 1892.) A general account of the conditions necessary for a successful flow of oil and gas, with an account of how these conditions are satisfied within the limits of Iowa so far as is known.

Newberria: a New Genus of Brachiopods. J. Hall. (Tenth Ann. Rep. State Geologist, New York, 91-102. 1891.)

Newberry, J. S., and A. H. Worthen. Description of new species of vertebrates. (Geol. Sur. Illinois, vol. II, pp. 9-134, with plates. Springfield, 1866.) A number of fossil fishes described from Iowa rocks. 
Newberry, J. S., and A. H. Worthen. Description of vertebrates. (Geol. Sur. Illinois, vol. IV., pp. 346374, with plates. Springfield, 1870.) New species of fishes described from Iowa.

New Conocardium from the Iowa Devonian. C. R. Keyes. (Proc. Iowa Acad. Sci., 1890-91, 23-24. 1892.) New Fossils from the Corniferous Formation at Davenport. W. H. Barris. (Proc. Davenport Acad. Nat. Sci., II, 282-288. 1878.)

New Species and New Genus of Tubicolar Annelida. S. Galvin. (Am. Geologist, I, 24-28. 1888.)

New Species of Crinoids and Blastoids. C. Wachsmuth and F. Springer. (Geol. Sur. Illinois, VIII, 157251. 1890.).

Niagara Limestone.

Chemical analyses. J. D. Whitney. (Geol. Iowa, I, 362-366. 1858.)

Fossils mentioned from Iowa localities. R. P. Whitfield. (Geol. Sur. Wisconsin, IV, 163-349. 1882.) General description. C. A. White. (Geol: Iowa, I, 182-184 1870.) A general account of its characters, features and economic value.

General description of the characters. James Hall. (Geol. Iowa, I, 71-73. 1858.)

New Species of Paleozoic Fossils. S. Calvin. (Bul.

Lab. Nat. Hist. State Univ. Iowa, I, 177-178. 1890.)

Notes Explanatory of a Section from Cleveland, Ohio, to the Mississippi River. J. Hall. (Trans. As. Am. Geologists and Naturalists, 267-293. 1843.) Incidental references to the geology of Iowa.

Of northeastern Towa. W. J. McGee. (U. S. Geol. Sur., 11th Ann. Rep., 323-326. 1892.) 
Niagara Limestone.-Continued.

Pockets of fire-clay in Niagara limestone. J. P. Farnsworth. (Am. Geologist, II, 331-334. 1888.)

Structure and Probable Affinities of Cerionites Dactylioides, Owen. S. Calvin. (Proc. Iowa Acad. Sci., I, pt. iii, pp. 13-15. 1893.)

"Nickel Ore" from Iowa. C. R. Keyes. (Eng. and Mining Journal, LIV, p. 634. 1892.)

Nicollet, J. N. Report intended to Illustrate a Map of the Hydrographic Basin of the Upper Mississippi River. (Sen. Doc., 26 Cong., 2nd Sess., vol. V, pt. ii, .No. 237. Washington, 1841.) A number of fossils are listed from various parts of Iowa and a few references are made to the rocks of the eastern part of the state.

Niles, W. H., and Charles Wachsmuth. Evidence of Two Distinct Geological Formations in the Burlington Limestone. (Am. Jour. Sci., (2), vol. XLII, pp. 95-99. 1866.) A short sketch of the Burlington beds with list of crinoids found in the upper and lower divisions.

Nishnabotna Sandstone.

In Mills county. C. A. White. (Geol. Iowa, I, 368370. 1870.)

In Montgomery county. C. A. White. (Geol. Towa, I, 363-366. 1870.)

Leaves found in the Nishnabotna sandstone. C. A.

White. (Geol. Iowa, I, 292-293. 1870.)

Occurrence of fossil leaves. C. A. White. (Am. Jour. Sci., (2), XLIV, 119. 1867.)

Norwood, J. G., and Henry Pratten. Notice of the Producti found in the Western States and Territories with Description of Twelve New Species. (Jour. Acad. Nat. 
Norwood, J. G., etc.-Continued.

Sci., Phila., (2), vol. III, pp. 5-22. Philadelphia, 1855.) A number of allusions to species occurring in Iowa.

Note on the Difference between Acervularia Profunda, Hall, and Acervularia Davidsoni, Edwards and Haime. S. Galvin. (Am. Geologist, IX, 365-368. 1892.)

Note on the Difference between Acervularia Profunda, Hall, and Acervularia Davidsoni, Edwards and Haime. S. Calvin. (Proc. Iowa Acad. Sci., 1890-91, 30-32. 1892.)

Note on the Distribution of Helicina Occulta. C. R. Keyes. (Am. Geologist, III, 18-19. 1889.)

Note on the Geological Range of the Genus Receptaculites in American Palæozoic Strata. J. Hall. (New York State Cab. Nat. Hist., 16th Ann. Rep., App. D, 67-69. 1863.)

Note sur le parallésme des roches des dépots paléozoiques de l' Amerique Septentrionale avec ceux de l' Europe, suivie d'un tableau des éspeces fossiles commones aux deux Continents, avec l' indication des étages on elles as recontrent, et terminée par un examen critique de chacune de ces éspeces. Ed. de Verneuil. (Bul. Soc. géol. de France, (2), t. IV, pp. 646-710. 1847.)

Notes Explanatory of a Section from Cleveland, Ohio, to the Mississippi River, in the Southwest Direction, with Remarks upon the Identity of the Western Formations with those of New York. J. Hall. (Trans. As. Am. Geologists and Naturalists, 267-293. 1842.)

Notes on a Collection of Fossils from the Lower Magnesian Limestone from Northeastern Iowa. S. Calvin. (Am. Geologist, X, 144-148. 1892.)

Notes on "Cone-in-cone.". C. A. White. (Am. Jour. Sci., (2), XLV, 400-401. 1868.) 
Notes on Some Points in the Structure and Habits of Palæozoic Crinoidea. F. B. Meek and A. H. Worthen. (Proc. Acad. Nat. Sci., Phil., XX, 323-334. 1868.)

Notes on the Distribution of Timber in Southwestern Iowa, with Inferences Concerning the Origin of Prairies. J. E. Todd. (Am. Naturalist, XII, 91-96. 1878.)

Notes on the Formations Passed Through in Digging the Deep Well at Washington, Iowa. S. Calvin. (Am. Geologist, I, 28-31. · 1888.)

Notes on the Fossil Wood from the Keokuk Limestone, Keokuk, Iowa. C. H. Gordon. (Proc. Iowa. Acad. Sci., 1887-9, 97-98. 1890.)

Notes on the Fossils of the Loess at Iowa City. B. Shimek. (Am. Geologist, I, 149-152. 1888.)

Notes on the Geological Formations of Iowa. S. Calvin. (Pamphlet, printed at World's Exposition at New Orleans, 1-8. 1884.)

Notes on the Geology of a Part of the Mississippi Valley. W. J. MeGee. (Geological Magazine, (2), VI, 412-420 and 353-362. 1879.)

Notes on the Geology of Johnson County. C. L. Webster. (Am. Naturalist, XXII, 408-419. 1888.)

Notes on the Geology of Southeastern Iowa. C. H. Gordon. (Am. Geologist, IV, 237-239. 1889.)

Notes on the Local Geology, No. II. W. H. Barris. (Proc. Davenport Acad. Nat. Sci., vol. III, pp. 163183. 1882.)

Notes on the Redrock Sandstone. C. R. Keyes. (Proc. Iowa Acad. Sci., vol. I, pt. iii, 26-27. 1892.)

Notes on the Rockford Shales. C. L. Webster. (Am. Naturalist, XXII, 444-446. 1888.) . 
Notes on the Synonymy, Characters and Distribution of Spirifera Parryana, Hall. S. Calvin. (Bul. Lab. Nat. Hist. State Univ. Iowa, I, 19-28. 1888.)

Notes upon the Geology of the Western States. J. Hall. (Am. Jour. Sci., XLII, 51-62. 1842.)

Notice of a New Species of Platycrinus and other Fossils from the Mountain Limestone of Illinois and Iowa. A. H. Worthen. (Trans. Acad. Sci., St. Louis, I, 569571. 1860.)

Notice of Arrow Points from the Loess in the City of Muscatine. F. M. Witter: (Proc. Iowa Acad. Sci., 1890-91, 66-68: 1892.)

Notice of the Producti found in the Western. States and Territories, with Description of Twelve New Species. J. G. Norwood and H. Pratten. (Jour. Acad. Nat. Sci., Phila., (2), III, 5-22. 1855.)

Number and Distribution of Fossil Species in the Paleozoic Rocks of Iowa, Wisconsin and Minnesota. D. D. Owen and B. F. Shumard. (Proc. Am. As. Ad. Sci., V, 235. 1851.)

Nuttall, Thomas. Observations on the Geological Structure of the Valley of the Mississippi. (Jour. Acad. Nat. Sci., Phila., vol. II, pp. 14-52. Philadelphia, 1821.) Some general allusions to Iowa geology. O'Brien County.

General description. C. A. White. (Geol. Iowa, II, 223-226. 1870.) Mere reference to the surface features.

Observations on Prairie Soil. W. H. Herrick. (Proc. Iowa Acad. Sci., 1875-80, 16. 1880.)

Observations on the Genus Archimedes, or Fenestella, with Description of Species, etc. J. Hall. (Proc. Am. As. Ad.'Sci., pp. 170-180. 1857.) 
Observations on the Geological Structure of the Valley of the Mississippi. T. Nuttall. (Jour. Acad. Nat. Sci., Phila., II, 14-52. 1821.)

Observations on the Keokuk Species of Agaricocrinus. C. H. Gordon. (Proc. Iowa Acad. Sci., 1887-9, 100101. 1890.)

Observations on the Keokuk Species of Agaricocrinus. C. H. Gordon. (Am. Geologist, V, 257-261. 1890.) Observations on the Red Quartzite Boulders of Western Iowa; and Their Original Ledges of Red Quartzite in Iowa, Dakota and Minnesota. C. A. White. (Proc. Am. As. Adv. Sei., XVII, 340-342, 1869.)

Observations on the Summit Structure of Pentremites, the Structure and Arrangement of Certain Parts of Crinoids, and Description of. New .Species from the Carboniferous Rocks of Burlington, Iowa. C. A. White. (Boston Jour. Nat. Hist., VII, 481-506. 1863.) Observations upon the Carboniferous Limestones of the Mississippi Valley. J. Hall. (Am. Jour. Sci., (2), XXIII, 187-203. 1857.)

Observations upon the Drift Phenomena of Southwestern Iowa. G. A. White. (Am. Jour. Sci., (2), XLIII, 301-305. 1867.)

Observations upon the Drift Phenomena of Southwestern Iowa. C. A. White. (Second Ann. Rep. State Geologist, 143-148. 1868.)

Observations upon the Geology and Paleontology of Burlington, Iowa, and its Vicinity. C. A. White. (Bost. Jour. Nat. Hist., VII, 209-235. 1860.)

Observations upon the Rocks of the Mississippi Valley which have been referred to the Chemung Group of New York, together with Deseriptions of New Species of Fossils from the same Horizon at Burlington, Iowa. 
Observations, etc.-Continued.

C. A. White and R. P. Whitfield. (Proc. Bost. Soc. Nat. Hist., VIII. 289-316. 1862.)

Occurrence of an Internal Convoluted Plate within the Body of Certain Species of Crinoidea. J. Hall. (Proc. Bost. Soc. Nat. Hist., X, 33-34. 1866.)

Occurrence of Fish Remains in the Carboniferous Limestone of Illinois. A. H. Worthen. (Proc. Am. As. Ad. Sci., X, 189-192. 1856.)

Occurrence of Natural Gas in Iowa and its Probable Future. C. R. Keyes. (Mon. Rev. Iowa Weather and Crop Service, III, No. 12, 3-4. 1892.)

On Attachment of Platycerata to Palæocrinoids; and its Effects in Modifying the Form of the Shell. C. R. Keyes. (Proc. Am. Philosophical Sóc., XXV, 231248. 1888.)

On Carboniferous Fossils from Jackson County. Herbert Osborn. (Proc. Iowa Acad. Sci., vol. I, pt. iii, 115. 1892.)

On Chert of the Upper Coal Measures in Montgomery County, Iowa. S. Calvin. (Am. Geologist, I, 116117. 1888.)

On Eastern Limit of Cretaceous Deposits in Iowa. C. A. White. (Proc. Am. As. Adv. Sci., XXI, 187-192. 1873.)

On Fauna found at Lime Creek, Iowa, and its Relation to Other Geological Faunas. S.Calvin. (Amer. Jour. Sci., XXV, 434-436. 1883.)

On Fauna of the Lower Coal Measures of Central Iowa. C. R. Keyes. (Proc. Acad. Nat. Sci., Phila., 231-247. 1888.)

On Folding of Carboniferous Strata in Southwestern Iowa. J. E. Todd. (Proc. Iowa Acad. Sci., 1887-9, 58. 1890.) 
On Fossils from the Lower Coal Measures at Des Moines, Iowa. C. R. Keyes. (Am. Geologist, II, 24-28. 1888.) On Glacial Flow in Iowa. C. L. Webster. (Am. Naturalist, $\mathrm{XXI}, 758-761$. 1887.)

On Iowa Kames and Aasar. W. J. McGee. (Proc. Iowa Acad. Sci., 1875-80, $19 . \quad$ 1880.)

On Keokuk Beds and Their Contained Fossils in the - Vicinity of Keokuk, Iowa. C. H. Gordon. (Proc. Iowa Acad. Sci., 1887-9, 98-100. 1890.)

On Loess and Associated Deposits of Des Moines. W.J. MoGee and R. E. Call. (Am. Jour. Sci., (3), XXIV, 202-223. 1883.)

On Maquoketa Shales and their Correlation with the Cincinnati Group of Southwestern Ohio. J. F. James. (Am. Geologist, V, 335-356. 1890.)

On Occurrence of Later Cretaceous Deposits in Iowa. C. A. White. (Am. Geologist, I, 221-227. 1888.)

On Parallelism of the Palæozoic Deposits of North America with those of Europe, etc. [Translated.] J. Hall. (Am. Jour. Sci., (2), V, 176-183 and 369-270. 1848.)

On Quaternary Section Eight Miles Southeast of Des Moines, Iowa. C. R. Keyes and R. E. Call. (Proc. Iowa Acad. Sci., vol. I, pt. iii, 30. 1892.)

On Relation of the Loess to Drift in Southwestern Iowa.

J. E. Todd. (Proc. Iowa Acad. Sci., 1875-80, 19. 1880.)

On Relation of the Devonian Faunas of Iowa. H.S. Williams. (Am. Geologist, III, 230-233. 1889.).

On-Relative Position of Forest Beds and Associated Drift Formations in Northeastern Iowa. W. J. McGee. (Am. Jour. Sci., (3), XV, 339-341. 1878.) 
On Roots and Root-marks Found in the Loess. J. E. Todd. (Proc. Iowa Acad. Sci., 17. 1880.)

On Spontaneous Fission ? in Zaphrentis. C. A. White. (Am. Jour. Sci., (3), V, 72. 1873.)

On Superposition of Glacial Drift upon the Residuary Clays. W. J. McGee. (Am. Jour. Sci., (3), XVIII, 301-303. 1879.)

On Synonomy of Two Species of Spirifera. S. A: Niller. (Proc. Davenport Acad. Nat. Sci., II, 220221. 1878.)

Oneota Limestone.

Of northeastern Iowa. W. J. McGee. (U. S. Geol. Sur., 11th Ann. Rep: 331-333. 1892.)

Onondaga-Salt Group.

General description of the characters. James Hall. (Geol. Iowa, I, 76-80. 1858.)

\section{Ophiurids.}

(Geol. Iowa, $1,76-80$. 1858.)

Description of new species from the lower Carboniferous of Iowa. F. B. Meek and A. H. Worthen. (Geol. Sur. Illinois, V, 323-619. 1873.)

Ore deposits of southwestern Wisconsin. T. C. Chamberlin. (Geol. Sur. Wisconsin, IV, 367-568. 1882.) Incidental references to Iowa.

Organic Remains of the Niagara Group and Associated Limestones. J. Hall. (Geol. Sur. Wisconsin, pt. iii, 1-94. 1871.)

Osborn, Herbert. On some Carboniferous Fossils from Jackson County. (Proc. Iowa Acad. Sei., 1890-1891, p. 115. Des Moines, 1892.) Specimens of plants reported from a Coal Measure pocket in Jackson county. Osceola County.

General description. C. A. White. (Geol. Iowa, II, 226-229. 1870.) Brief mention of the surface features. 
Ovibos Cavifrons from the Loess of Iowa. W. J. MIcGee. (Am. Jour. Sci., (3), XXXIV, 217-220. 1887.)

Owen, D. D. Abstract of an Introduction to the final Report on the Geological Survey made in Wisconsin, Iowa, and Minnesota in the years of 1847-1850, Containing a Synopsis of the Geological Features of the Country. (Proc. Am. Assoc. Ad. Sci., vol. V, pp. 119. 131. 1851.) A number of references to the geology of Iowa.

Owen, D. D. Description of New and Imperfectly known Genera and Species of Organic Remains, Collected during the Geological Surveys of Wisconsin, Iowa, and Minnesota. (Geol. Sur. Wisconsin, Iowa and Minnesota, App., Art. ii, pp. 573-587. Philadelphia, 1852.) Numerous species from Iowa described as new.

Owen, D. D. Geological Chart of Part of Iowa, Wisconsin and Illinois. (Report of a Geological Exploration of Part of Iowa, Wisconsin and Illinois, made in the autumn of the year 1839. [Washington], 1844.) An edition of the report was printed in 1840 , but without the accompanying charts. Washington is not named in the title pages as the place of publication; the only inscription is, "Ordered to be printed by the Senate of the United States."

Owen; D. D. Geological Section from the Mouth of Rock River through the Blue Mounds to the Wisconsin River, in Connection with a Geological Chart of Part of Iowa, Wisconsin and Illinois. (Report of - Geological Explorations of Parts of Iowa, Wisconsin and Illinois, made in the autumn of the year 1839, Plate iii. [Washington], 1844.) 
Owen, D. D. On the Geology of the Western States. (Am. Jour. Sci., vol. XLV, pp. 151-153. New Haven, 1843.) Incidental references to the Iowa coal field.

Owen, D. D. Provisional Geological Map of Part of the Chippewa Land District of Wisconsin, with Part of Iowa, and of Minnesota Territory to Illustrate the Report of a Geological Reconnaissance made in 1847. (Report of a Geological Reconnaissance of the Chippewa land district of Wisconsin; and incidentally of a portion of the Kickapoo country, and of a part of Iowa and of the Minnesota Territory. [Washington, 1849.]) Neither date nor place of publication is given, but very likely Washington is the place.

Owen, D. D. Report of a Geological Exploration of Iowa, Wisconsin and Illinois, made under instructions of the Secretary of the Treasury of the United States in the Autumn of 1839. (House of Rep., Exc. Doc., 26 Cong., 1st Sess., No. 239, 161 pp. Washington, 1840.)

Owen, D. D. Report of a Geological Survey of Wisconsin, Iowa and Minnesota. (pp. i-xxxiii and 1-638. Philadelphia, 1852.) Several of the sections of chapter I treat of the geology of various formations in northeastern Iowa.

Chapter II is a description of geological formations along the Red Cedar, Iowa and Wapsipinicon rivers in eastern Iowa.

Chapter III gives an account of the Carboniferous rocks of Iowa, chiefly along the Des Moines and Raccoon rivers.

The other chapters are devoted to regions outside of Iowa. The report is illustrated by many figures, nụmerous plates and maps. 
Owen, D. D., and B. F. Shumard. Description of One New Genus and Twenty-two New Species of Crinoidea from the Subcarboniferous Limestone of Iowa. (Rep. Geol. Sur. Wisconsin, Iowa and Minnesota, App., art. ii, pp. 587-598. Philadelphia, 1852.)

Owen, D. D., and B. F. Shumard. On the Number and Distribution of Fossil Species in the Paleozoic Rocks of Iowa, Wisconsin and Minnesota. (Proc. Am. Assoc. Ad. Sci., vol. V, p. 235 . 1851.) A number of forms noted from Iowa.

Page County.

General description of geology. C. A. White. (Geol. Iowa, I, 348-353. 1870.) The surface characters and geology described with sections.

New Species of Palæozoic Fossils. S. Calvin. (Bul. Lab. Nat. Hist. State Univ. Iowa, I, 176. 1890.) Paint (Mineral).

In Iowa. C. A. White. (Geol. Iowa, II, 328-329. 1870.) Ochery clay resembling that used for making paint reported from several localities.

Paleontology of Illinois. F. B. Meek and A. H. Worthen. (Geol. Sur. Illinois, III, 289-565. 1868.)

Paleontology of New York. J. Hall. (Nat. Hist. New York, Paleontology, IV, 422 pp. 1867.) Incidental references to Iowa fossils.

Paleontology of Wisconsin. R. P. Whitfield. (Geol. Sur. Wisconsin, IV, 163-349. 1882.) Incidental references to Iowa fossils.

Paleozoic Bryozon. E. O. Ulrich. (Geol. Sur. Illinois, VIII, 283-688. 1890.)

Paleozoic Formations of Southeastern Minnesota. C. W. Hall and F. W. Sardeson. (Bul. Geol. Soc. America, III, 331-368. 1892.) Incidental references to Iowa stratigraphy. 27 G. Rep. 


\section{Palo Alto County.}

Deep Well at Emmettsburg, Iowa. N. H. Winchell. (Bul. Minnesota Acad. Sci., I, 387-390. 1880.)

General description. C. A. White. (Geol. Iowa, II, 215-218. 1870.) Brief account of its surface features.

Parvin, T. S. Climate. (Geology Iowa, vol. I, Chapter iv, pp. 139-164. Des Moines, 1870.) A summary of the climatology of the state, based upon observations from 1839 to 1870 ; with tables of mean temperatures, winds, rain, snow, etc.

Peats.

Analyses. Rush Emery. (Geol. Iowa, II, 397-404. 1870.)

Brief account of its occurrence in various counties; and the manner of obtaining it. C. A. White. (Second Ann. Rep. State Geologist, 121-135. 1868.)

In Adair county. C. A. White. (Geol. Iowa, I, 339. 1870.)

Reported from near Davenport. W. H. Pratt. (Proc. Davenport Acad. Sci., I, 96-99. 1876.)

Perisomic Plates of the Crinoids. C. Wachsmuth and F. Springer. (Proc. Acad. Nat. Sci., Phila., 345 392. 1890.)

\section{Petroleum.}

Natural Gas and Oil in Iowa. C. R. Keyes. (Proc.

Iowa Acad. Sci., I, pt. iii, pp. 15-18. 1893.)

Phyllites Crétacees du Nebraska. J. Capellini et O. Heer. (Mém. Soc. Helvétique des Sci. Nat., XXII, 1-24. 1867.) Physical Geography.

Of Iowa. J. D. Whitney. (Geol. Iowa, I, 1-34. 1858.) Sketch of the Physical Geography of Iowa. R. E. Call. (Ann. Rep. Iowa Weather and Crop Service, 12-18. 1891.) 


\section{Plants.}

Fossil wood from the Keokuk formation, Keokuk, Iowa. S. J. Wallace. (Am. Jour. Sci., (3), XV, 396. 1878.)

In Cretaceous Rocks of Iowa. C. A. White. (Am. Jour. Sci., (2), XXIV, 119. 1867.)

Localities in Iowa. L. F. Ward. (U. S. Geol. Sur., 8th Ann. Rep. 895-896. 1867.)

Leaves found in the Nishnabotna Sandstone. C. A. White. (Geol. Iowa, I, 292-293. 1870.)

On some Carboniferous Fossils from Jackson County. HerbertOsborn. (Proc. Iowa Acad. Sci., 1890-1891, 115. 1892.) Lepidodendron and Calamites reported from a Coal Measure pocket in Jackson county. Wood Found in Keokuk limestone at Keokuk. C. H.

Gordon. (Proc. Iowa Acad. Sci., 1887-9, 97-98. 1890.)

Platyceras Group of Paleozoic Gasteropods. C. R. Keyes. (Am. Geologist, X, 273-277. 1892.)

Pleistocene History of Northeastern Iowa. W. J. McGee. (U. S. Geol. Sur., 11th Ann. Rep. 190-577. Washington, 1892.)

Plymouth County:

General description. C. A. White. (Geol. Iowa, II, 229-232. 1870.) Brief reference to the geology.

Pocahontas County.

General description. C. A. White. (Geol. Iowa, II, 218-219. 1870.) Brief general reference to the surface features of the county.

Pockets Containing Fire-Clay and Carboniferous Material in the Niagara Limestone at Clinton, Iowa. J. P. Farnsworth. (Am. Geologist, II, 331-334. 1888.) 


\section{Polk County.}

Brick and Other Clays of Des Moines. ' C. R. Keyes. (Proc. Iowa Acad. Sci., 1890-1891, 29. 1892.) A brief statement of the clay industries at Des Moines. Contribution to the Fauna of the Lower Coal Measures of Central Iowa. C. R. Keyes. (Proc. Iowa Acad. Sci., 1890-1891, 22-23. 1892.) A preliminary note. Three species described from the Lower Coal Measures at Des Moines.

Coal Measures in the vicinity of Des Moines. C. R. Keyes. (Am. Geologist, II, 396-404. 1888.)

Coal. C. A. White. (Geol. Iowa, II, 261-262. 1870.) Eastern Extension of the Cretaceous in Iowa. C. R. Keyes. (Proc. Iowa Acad. Sci., 1890-1, 21. 1892.) Notes on cretaceous fossils found in the drift and remarks on the eastern limits of the rocks in Iowa.

Fossil Faunas in Central Iowa. C. R. Keyes. (Proe: Acad. Nat. Sci., Phila, 242-265. 1891.) Notes and bibliographic references of the species found in the lower Coal Measures of the central part of the state.

Fossils at Des Moines. C. R. Keyes. (Am. Geologist, II, 24-28. 1888.) List and remarks.

Geological Structure and Relations of the Coal-Bearing strata of Central Iowa. C. R. Keyes. (Proc. Iowa Acad. Sci., 1890-91, 27-28. 1892.) A summary of observations made along the Des Moines river, chiefly in the vicinity of Des Moines.

List of fossils from the Des Moines river above the Raccoon Fork. J. N. Nicollet. (Sen. Doc., 26 Cong., 2nd. Sess., V, pt. ii, No. 237. 1841.)

Loess and Associated Deposits of Des Moines. W. J. McGee and R. E. Gall. (Am. Jour. Sci., (3), XXIV, 202-223. 1882.) 
Polk County.-Continued.

Loess in central Iowa. R. E. Call. (Am. Naturalist, XV, 782-784. 1881.)

Quaternary Section Eight Miles Southeast of Des Moines, Iowa. C: R. Keyes and R. E. Call. (Proc. Iowa Acad. Sci., 1890-1891, 30. 1892.) Description of a section near the terminal moraine in the vicinity of Des Moines.

Polyzoans.

New species from the Lower Garboniferous of Iowa. A.

H. Prout. (Geol. Sur. Illinois, II, 412-524. 1866.) Pottawattamie County.

Brief notes on the surface geology. C. A. White. (First Ann. Rep. State Geologist, 59-63. 1868.)

General description. C. A. White. (Geol. Iowa, I, 376-381. 1870.) Brief general account of its surface characters and geology.

Ovibos Cavifrons found in the Loess at Council Bluffs. W. J. McGee. (Am. Jour. Sci., (3), XXXIV, 217220. 1887.)

\section{Pottery Clay.}

In Henry county. A. H. Worthen. (Geol. Iowa, I, 218. 1858.)

Occurrence in Iowa. C. A. White. (Geol. Iowa, II, 327-328. 1870.)

\section{Potsdam Sandstone.}

Description of the Lower Sandstone of the Upper Mississippi. (Potsdam). D. D. Owen. (Geol. Sur. Wis., Iowa and Minn., 48-58. 1852.) A detailed account of its lithological characters, range and paleontology.

General description. C. A. White. (Geol. Iowa, I, 171-172. 1870.) The general characters and economic value briefly stated. 


\section{Potsdam Sandstone.-Continued.}

General description of the characters. James Hall. (Geol. Iowa, I, 47-49. 1858.)

Its correlation. C. D. Walcott. (U. S. Geol. Sur., Bul. 81, 187-188. 1891.)

Of northeastern Iowa. (W. J. McGee. U. S. Geol. Sur., 11th Ann. Rep., 333-334. 1892.)

Physical ${ }^{\circ}$ characters. J. D. Whitney. (Geol. Iowa, I, 328-331. 1858.)

\section{Poweshiek County.}

Analyses of coal. Rush Emery. (Geol. Iowa, II, 393. 1870.)

Geological notes. J. D. Whitney. (Geol. Iowa, I,

\section{Prairies.} 266-273. 1858.)

Notes on the Distribution of Timber in Southwestern Iowa. J. E. Todd. (Am. Naturalist, XII, 91-96. 1878.)

Observations on Prairie Soil. W. H. Herrick. (Proc. Iowa Acad. Sci., 1875-80, $16 . \quad 1880$.)

Origin in Iowa. J. D. Whitney. (Geol. Iowa, I, 1425. 1858.)

Pratt, W. H. Report on a Geological Examination of the Section of the Bluffs recently exposed by the C., R. I. \& P. R. R. (Proc. Davenport Acad. Sci., vol. I, pp. 96-99. Davenport, 1876.) Notice of the loess, drift, clays and peat near Davenport.

Pratt, W. H. Section of the Bluff at Sixth Street, Davenport. . (Proc. Davenport Acad. Sci., vol. III, pp. 127-129. Davenport, 1881.) A description of the geological formations exposed at Sixth street at Davenport and a boring at the same place.

Pratt, W. H., J. Gass and. Bones of the Mammoth in 
Pratt, W. H., etc.-Continued.

Washington County, Iowa. (Proc. Davenport Acad. Sci., vol. III, pp. 177-178. Davenport, 1882.)

Pratten, Henry, J. G. Norwood and. Notice of the Producti found in the Western States and Territories, with Description of Twelve New Species. (Jour. Acad. Nat. Phila., (2), vol. III, pp. 5-22. Philadelphia, 1855.) See J. G. Norwood and Henry Pratten, 1855. Preliminary Note on the Sedentary Habits of Platyceras. C. R. Keyes. (Proc. Iowa Acad. Sci., 1890-91, 24. 1892.)

Preliminary Notice of New Genera and Species of Fossils. C. A. White and O. H. St. John. (Pamphlet, pp. 1-3. Iowa City, 1867.)

Preliminary Notice of Sphæroidocrinoidæ. C. Wachsmuth. (Proc. Iowa Acad. Sci., 1875-80, 22. 1880.)

Preliminary Paper on Artesian Wells in Iowa. R. E. Call. (Monthly Rev. Iowa Weather and Crop Service, II, 1-6. 1891.)

Principal Mississippian Section. C. R. Keyes. (Bul. Geol. Soc. America, III, 283-300. 1892.)

Proposed Economical Geological Survey of Iowa. [C. R. Keyes.] (Pamphlet, pp. 1-8. 1891.)

Protozoans.

From eastern Nebraska. F. B. Meek. (Final Report U. S. Geol. Sur. Nebraska, pt. ii, 83-245. 1872.)

Structure and Probable Affinities of the Cerionites

Dactylioides, Owen. S. Calvin. (Proc. Iowa Acad. - Sci., I, pt. iii, pp. 13-15. 1893.)

Prout, A. H. Description of Polyzoa from Paleozoic rocks. (Geol. Sur. Illinois, vol. II, pp. 412-424. Springfield, 1866.) A number of species described from Iowa rocks. 
Provisional Geological Map of Part of the Chippewa Land District of Wisconsin, with Part of Iowa and of Minnesota Territory, to Illustrate the Report of a Geological Reconnaissance made in 1847 . D. D. Owen. (Report of a Geological Reconnaissance of the Chippewa Land District of Wisconsin ; and Incidentally of a Portion of the Kickapoo Country and of a Part of Iowa and of the Minnesota Territory. . [Washington], 1849.)

\section{Pyrites.}

In coal. J. D. Whitney. (Geol. Iowa, I, 399. 1858.) Recent finds described in detail. C. R. Keyes. (Proc. Iowa Acad. Sci., I, pt. iii, 19-22. 1893.)

\section{Quarries.}

In Dubuque county. C. A. White. (Geol. Iowa, II, 314-315. 1870.)

In Johnson county. C. A. White. (Geol. Iowa, II, 308-309. 1870.)

In Jones county. C. A. White. (Geol. Iowa, II, 309311. 1870.)

In Marion county. G. A. White. (Geol. Iowa, II, 315. 1870.)

In Lee county. C. A. White. (Geol. Iowa, II, 314. 1870.)

In Marshall county. C. A. White. (Geol. Iowa, II, 312-314. 1870.)

In Scott county. C. A. White. (Geol. Iowa, II, 311312. 1870.)

Quaternary.

Artesian Wells in Iowa. R. E. Call. (Proc. Iowa Acad. Sci., 1890-91, 57-63. 1892.) Description of wells in the drift.

Additional Observations on Iowa Kames and Aasar. 
Quaternary.-Continued.

W. J. MIcGee. (Proc. Iowa Acad. Sci., 1875-80, 25. 1880.)

Bones of the Mammoth in Washington county, Iowa. J. Gass and W. H. Pratt. (Proc. Davenport Acad. Nat. Sci., III, 177-178. 1882.)

Charcoal Streak in the Loess. J. E. Todd. (Proc. Iowa Acad. Sci., 1875-1880, 21. 1880.)

Complete Series of Superficial Geological Formations in Northeastern Iowa. W. J. McGee. (Proc. Am. As. Ad. Sci., XXVII, 198-231. 1878.)

Cretaceous fossils in the drift of Hardin county. C. A. White. (Am. Geologist, I, 221-227. 1888.)

Cretaceous fossils in the drift. C. A. White. (Proc. Am. As. Adv. Sci., XXI, 187-192. 1873.)

Derivation of Iowa Drift. C. A. White. (Am. Naturalist, II, 615-616. 1869.)

Description of the deposits near Davenport. W. $H$. Pratt. (Proc. Davenport Acad. Nat. Sci., I, 96-99. 1876.)

Distribution of fossils in the Loess. C. R. Keyes. (Am. Geologist, VI, 119. 1890.)

Distribution of the Loess in eastern Iowa. W. J. McGee. (Bul. Phil. Soc. Washington, VI, 93-97. 1883.)

Driftless area of the upper Mississippi. T. C. Chamberlin and R. D. Salisbury. (U. S. Geol. Sur., 6th Ann. Rep., 199-322. 1886.)

Eastern Extension of the Cretaceous in Iowa. C. R. Keyes. (Proc. Iowa Acad. Sci., 1890-91, 21. 1892.) Cretaceous fossils found in the drift at Des Moines. Evidence of glacial origin of Iowa Drift. C. A.White. (Geol. Iowa, I, 92-100. 1870.) Glacial scratches 


\section{Quaternary.-Continued.}

in various parts of the state mentioned, and their directions. Copper, lead ore, coal, wood, fossils, and other substances of northern origin noted in the drift.

Fossils of the Iowa Loess. R. E. Call. (Am. Naturalist, $\mathrm{XV}, 585-586 . \quad 1881$.

Fossils from the Loess of Iowa. C. R. Keyes. (Bul. Essex Inst., XX. 1889.)

Geology of the Middle Region of Western Iowa. 0 . H. St. John. (Second Ann. Rep. State Geologist, 191-201. 1868.) .

Glacial scratches at Iowa City. C. L. Webster. (Am. Naturalist, XXI, 758-761. 1887.)

History of the Drift Deposits of Iowa. J. E. Todd. (Proc. Iowa Hort. Soc., XVIII, 316-327. 1883.)

In Henry county. A. H: Worthen. (Geol. Iowa, I, 210-211. 1858.)

In Lee county. A.H.Worthen. (Geol. Iowa, I, 187188. 1858.)

In Madison county. C. A. White. (Geol. Iowa, I, 305-308. 1870.)

In southeastern Iowa. C. A. White. (Am. Jour. Sci.; (2), XLIV, 119. 1867.) Additional note to an article of the same title.

In Van Buren county. A. H.Worthen. (Geol. Iowa, I, 221. 1858.)

Iowa drift. C. A. White. (Am. Naturalist, II, 615616. 1869.) Calls attention to the original site of the granite boulders found in Iowa.

Loess and Associated Deposits of Des Moines. W. J. McGee and R. E. Call. (Am. Jour. Sci., (3), XXIV, 202-223. 1882.) 


\section{Quaternary.-Continued.}

Loess and its fossils. B. Shimek. (Bul. Lab. Nat. Hist. State Univ. Iowa, II, 89-98. 1890.)

Loess and its fossils. B. Shimek. (Bul. Lab. Nat. Hist. State Univ. Iowa, I, 200-214. 1890.)

Loess and its soils. J. E. Todd. (Proc. Iowa Hort. Soc., XVII, 263-270. 1882.)

Loess fossils at Iowa City. B. Shimek. (Am. Geologist, I, 149-152. 1888.)

Loess at Muscatine. F. M. Witter. (Proc. Iowa Acad. Sci., 1875-1880, 16. 1880.)

Loess in Central Iowa. R. E. Call. (Am. Naturalist, $\mathrm{XV}, 782-784$. 1881.)

Loess of North America. R. E. Call. (Am. Naturalist, XVI, 369-381. 1882.)

Megalonyx found in Mills county. J. E. Todd. (Proc. Am. As. Ad. Sci., XXXVII, 202-203. 1889.)

Notes on the Geology of Johnson County. C. L. Webster. (Am. Naturalist, XXII, 408-419. 1888.) Notes on the Geology of a Part of the .Mississippi Valley. W. J. McGee. (Geological Magazine, (2), VI, pp. 412-420 and 353-362. 1879.)

Notice of Arrow Points from the Loess in the City of Muscatine. F. M. Witter. (Proc. Iowa Acad. Sci., 1890-91, 66-68. 1892.)

Observations upon the Loess. F. M. Witter. (Proc. Iowa Acad. Sci., 1887-9, 45. 1890.)

Observations upon the Drift Phenomena of Southwestern Iowa. C. A. White. (Am. Jour. Sci., (2), XLIII, 301-305. 1867.)

Observations upon the Drift Phenomena. C. A. White. (Second Ann. Rep. State Geologist, 143148. 1868.) 
Quaternary.-Continued.

Of eastern Iowa. W. J. McGee. (Pamphlet, 1-14. Ft. Dodge, 1884.)

On a Quaternary Section EightMiles Southeast of Des Moines, Iowa. C. R. Keyes and R. E. Call. (Proc. Iowa Acad. Sci., 1890-91, 30. 1892.) Description of a section near the terminal moraine near Des Moines.

On the Relation of Loess to Drift in Southwestern Iowa. J. E. Todd. (Proc. Iowa Acad. Sci., 187580, 19. 1880:)

On the Roots and Root-marks Found in the Loess. J. E. Todd. (Proc. Iowa Acad. Sci., 1875-80, 17. 1880.)

On some Iowa Kames and Aasar. W. J. McGee. (Proc. Iowa Acad. Sci., 1875-80, 19. 1880.)

Ovibos Cavifrons from the Loess at Council Bluffs. W. J. McGee. (Am. Jour. Sci., (3), XXXIV, 217220. 1887.)

Pleistocene History of Northeastern Iowa. W. J. McGee. (U. S. Geol. Sur., 11th Ann. Rep., 190577. 1892.)

Quartzite boulders in western Iowa. C. A. White. (Proc. Am. As. Adv. Sci., XVII, 340-342. 1869.) Quaternary Geology of Keokuk, Iowa, with Notes on the Underlying Rock Structure. C. H. Gordon. (Am. Geologist, IX, 183-190. 1892.)

Recent Wind Action upon the Loess. J. E. Todd. (Proc. Iowa Acad. Sci., 1875-1880, 21. 1880.)

Relative Position of Forest Beds and Associated Drift Formations in Northeastern Iowa. W. J. McGee. (Am. Jour. Sci., (3), XV, 339-341. 1878.)

Richthofen's Theory of the Loess in the Light of the 
Quaternary:-Continued.

Deposits of the Missouri. J. E. Todd. (Proc. Am. As. Ad. Sci., XXVII, 231-239. 1878.)

Rock Scoring of the Great Ice Invasion. T. C. Chamberlin. (U. S. Geol. Sur., 7th Ann. Rep., 147-248. 1888.)

Section of the Bluff at Sixth Street, Davenport. W.

H. Pratt. (Proc. Davenport Acad. Sci., III, 127129. 1881.)

Superposition of Glacial Drift upon Residuary Clays. W. J. MeGee. (Am. Jour. Sci., (3), XVIII, 301303. 1879.)

Surface Geology of Keokuk. C. H. Gordon. (Am. Geologist, IX, 183-190. 1892.)

Surface Geology of the Raccoon River Region. O. H. St. John. (Second Ann: Rep. State Geologist, 173190. 1868.)

Surface Deposits of Keokuk, Iowa. C. H. Gordon. (Rep. Dep. Nat. Hist. Northwestern Univ., 11-19. 1891.), Short account of geology, with rock sections and sketch-map.

Surface Geology of Burlington, Iowa. C. R. Keyes.

(Am. Naturalist, XXII, 1049-1054. 1888.) A sketch of the Quaternary formations around Burlington.

Terminal Moraine of the Second Glacial Epoch. T. C. Chamberlin. (U. S. Geol. Sur., 3d Ann. Rep., 291-404. 1883.)

Topographic Types of Northeastern Iowa. W. J. McGee. (Proc: Am. As. Ad. Sci., XXXVII, 248249. 1890.)

Transitional Drift of a Portion of Northern Iowa. C. L. Webster. (Am. Naturalist, XXIV, 11821185. 1890.) 
Recent Wind Action upon the Loess. J. E. Todd. (Proc. Iowa Acad. Scị., 1875-80, 21. 1880.)

Reconnaissance géologique au Nebraska. J. Marcou. (Bul. Soc. géol. de France, (2), t. XXI, p. 137. 1864.) Recorded Meteorites of Iowa, with Special Mention of the Last or Winnebago County Meteorite. E. H. Barbour and Joseph Torrey. (Am. Geologist, VIII, 65-72. 1891.)

Redrock Sandstone of Marion County, Iowa. C. R. Keyes. (Am. Jour. Sci., (3), XLI, 273-276. 1891.)

Relations of Geology and Agriculture. W. J. McGee. (Trans. Iowa State Hort. Soc., XVI, 227-240. 1884.) Remarkable Fauna at the Base of the Burlington Limestone in Northeastern Missouri. C. R. Keyes. (Am. Jour. Sci., (3), XLIV, 247-252. 1892.)

Remarkable Fauna at the Base of the Chemung Group in New York: H. S. Williams. (Am. Jour. Sci., (3), XXV, 97-104. 1883.)

Remarks on Prof. Geinitz's Views Respecting the Upper Paleozoic Rocks and Fossils of Southeastern Nebraska. F. B. Meek. (Am. Jour. Sci., (2), XLIV, 170-187. 1867.)

Remarks on Some Types of Carboniferous Crinoids, with Descriptions of New Genera and -Species of the Same, and of one Echinoid. F. B. Meek and A. H. Worthen. (Proc. Acad. Nat. Sci., Phila., XX, 335359. 1868.)

Remarks on the Blastoidea, with Descriptions of New Species. F. B. Meek and A. H. Worthen. (Proc. Acad. Nat. Sci., Phila., XXI, 83-91. 1869.). .

Remarks on the Carboniferous and Cretaceous Rocks of Eastern Kansas and Nebraska, and their Relations to those of the Adjacent States, and other Localities 
Remarks, etc.-Continued.

farther Eastward; in Connection with a Review of a Paper Recently Published on this Subject by M. Jules Marcou in the Bulletin of the Geological Society of France. F. B. Meek. (Am. Jour. Sci., (2), XXXIX, 159-174. 1856.)

Remarks on the Genus Taxocrinus (Phillips) M[cCoy, 1844, and its Relations to Forbesiocrinus, Koninck and Le Hon, 1854 ; with Description of New Species. F. B. Meek and A. H. Worthen. (Proc. Acad. Nat. Sci., Phila., XVII, 138-143. 1865.)

Report Intended to Illustrate a Map of the Hydrographic Basin of the Upper Mississippi River. J. N. Nicollet. (Sen. Doc., 26 Cong., 2nd Sess., V, pt. ii, No. 237. 1841.)

Report of a Geological Exploration of Iowa, Wisconsin and Illinois, made under instructions of the Secretary of the Treasury of the United States in the Autumn of 1839 . D. D: Owen. (House of Rep., Exec. Doc., 26 Cong., 1st Sess., No. 239, 161 pp. 1840.)

Report of Meteorites. C. U. Sheppard. (Am. Jour. Sci., (2), VI, 402-417. 1848.)

Report of the Assistant State Geologist. O. H. St. John. (Second Ann. Rep. State Geologist, 84-87. 1868.)

Report of the Geological Survey of the State of Iowa. J. Hall. (Vol. I, pp. i-xv, and 1-724. 1858.)

Report of the Geological Survey of the State of Iowa. C. A. White. (Vol. I, pp. i-viii and 1-391. 1870.)

Report of the Geological Survey of Iowa. C. A. White. (Vol. II, 1-435. 1870.)

Report of Geological Survey of Wisconsin, Iowa and Minnesota. D. D. Owen. (1-638. Philadelphia, 1882.) 
Report of the Geology of the State of Iowa. J. Hall. (Vol. I, 474-724. 1858.)

Report of the Mine Inspector for the First District. T. Binks. (Third Biennial Rep. State Mine Inspectors, 1-80. 1888.)

Report of the Mine Inspector for the First District. T. Binks. (Fourth Biennial Rep. State Mine Inspectors, 1-65. 1889.)

Report of the Mine Inspector for the First District. T. Binks. (Fifth Biennial Rep. State Mine Inspectors, 1-51. 1891.)

Report of the Mine Inspector for the Second District. J. A. Smith. (Third Biennịal Rep. State Mine Inspectors, 81-112. 1888.)

Report of the Mine Inspector of the Third District. J. A. Stout. (Third Biennial Rep. State Mine Inspectors, 117-177. 1888.)

Report of the Mine Inspector for the Third District. J. Stout. (Fourth Biennial Rep. State Mine Inspectors, 115-151. 1889.)

Report of the Mine Inspector for the Third District. M. C. Thomas. (Fifth Biennial Rep. State Mine Inspectors, 95-141. 1891.)

Report of the Mine Inspector for the Second District. J. Gildroy. (Fourth Biennial Rep. State Mine Inspectors, 16-114. 1889.)

Report of the Mine Inspector for the Second District. J. Gildroy. (Fifth Biennial Rep. State Mine Inspectors, 1890-1891, 55-92. 1891.)

Report of the Paleontology of Eastern Nebraska, with Remarks on the Rocks of that District. F. B. Meek. (Final Report U. S. Geol. Sur. Nebraska, 83-245. 1872.) 
Report of the State Chemist. Gustavus Hinrichs. (First Ann. Rep. State Geologist, 9-10. 1868.)

Report of the State Chemist. Gustavus Hinrichs. (Second Ann. Rep. State Geologist, 203-279. 1868.)

Report of the State Chemist. Gustavus Hinrichs. (Second Ann.' Rep. State Geologist, 263-279. 1868.)

Report on a Geological Examination of the Bluffs recently exposed by the C., R. I. \& P. R. R. T. H. Pratt. (Proc. Davenport Acad. Sci., I, 96-99. 1876.) Report on the Invertebrate Cretaceous and Tertiary Fossils of the Upper Missouri Country. F. B. Meek. (U. S. Geol. Sur. Terr., IX. 1876.) Numerous incidental references to Iowa.

Revision of the Palæocrinoida, Part I. C. Wachsmuth and F. Springer. (Proc. Acad. Nat. Sci., Phila., 1879, 226-379. 1879.)

Revision of the Palæocrinoidæ, Part II. C. Wachsmuth and F. Springer. (Proc. Acad. Nat. Sci., Phila., 1881, 177-314. 1881.)

Revision of the Palæocrinoidæ, Part III, Section 1. C. Wachsmuth and F. Springer. (Proc. Acad. Nat. Sci., Phila., 1885, 225-364. 1885.)

Revision of the Palæocrinoidæ, Part III, Section 2. C. Wachsmuth and F. Springer. (Proc. Acad. Nat. Sci., Phila., 64-226. 1886.)

Richthofen's Theory of the Loess in the Light of the Deposits of the Missouri. J. E. Todd. (Proc. Am. As. Ad. Sci., XXVII, 231-239. 1878.)

\section{Ringgold County.}

Brief reference to the surface features. C. A. White. (First Ann, Rep. State Geologist, 43-45. 1868.)

General description. C. A. White. (Geol. Iowa, I, 328-330. 1870.) Brief reference of its geology and surface characters. 


\section{Rivers.}

General description. J. D. Whitney. (Geol. Iowa, I 2-11. 1858.) A short general account of the drainage system of Iowa.

General drainage features. C. A. White. (Geol. Iowa, I, 35-70. 1870.) General course and characters of the rivers, with estimates of average fall of the principal streams. Also special description of the different water courses.

Road Materials.

Occurrence in Iowa. C. A. White. (Geol. Iowa, II, 329-330. 1870.)

Rocks.

Analyses. G. Hinrichs. (Second Ann. Rep. State Geologist, 238-247. 1868.)

Analyses. Rush Emery. (Geol. Iowa, II, 345-349. 1870.)

Rock Scorings of the Great Ice Invasions. T. C. Chamberlin. (U. S. Geol. Sur., 7th Ann. Rep., 147-248. 1888.)

Rockford Shales.

Brachiopods from various localities in Iowa. J. Hall.

(Nat. Hist. New York, Pal, VIII, 1-269. 1892.)

Distribution of Rockford Shales. C. L. Webster.

(Proc. Davenport Acad. Sci., V, 100-109. 1887.)

Notes on the shales. C. L. Webster. (Am. Naturalist, XXII, 444-446. 1888.)

Pachyphyllum from the Rockford shales. C. L.

Webster. (Am. Nat., XXIII, 621-625. 1889.)

Sac County.

General description. O. H. St. John. (Geol. Iowa, II, 150-158. 1870.)

Saint Louis Limestone.-(See St. Louis Limestone.) 
Saint Peter Sandstone.-(See St. Peter Sandstone.)

Salisbury, R. D., T. C. Chamberlin and. Preliminary Paper on the Driftless Area of the Upper Mississippi Valley. (U. S. Geol. Sur., 6th Ann. Rep., pp. 199-322. 1886.) See T. C. Chamberlin and R. D. Salisbury, 1886.

Sand.

In the Drift. C. A. White. (Geol. Iowa, I, 84. 1870.)

Occurrence in Iowa. . C. A. White. (Geol. Iowa, II, 322-323. 1870.)

\section{Sandstones.}

Age of Certain Sandstones near Iowa City. C. R. Keyes. (Proc. Iowa Acad. Sci., 1890-91, 26. 1892.) Owing to the recent discovery of fossils in the sandstones near Iowa City the suggestion is made that their age may be Kinderhook (Lower Carboniferous) instead of Upper Coal Measures as have been heretofore regarded.

Notes on the Redrock Sandstone. C. R. Keyes. (Proc. Iowa Acad. Sci., 1890-91, 26-27. 1892.) A Preliminary account of the stratigrapical relations.

Redrock Sandstone of Marion County, Iowa. C. R.

- Keyes. (Am. Jour. Sci., (3), XLI, 273-276. 1891.)

A description of the formation and its unconformities.

Sardeson, F. W., C. W. Hall and. Paleozoic Formations of Southeastern Minnesota. (Bul. Geol. Soc. America, vol. III, pp. 331-368. 1892.) C. W. Hall and F. W. Sardeson, 1892.

Scott County.

Artesian Well at Davenport. A. S. Tiffany. (Am. Geologist, III, 117-118. 1889.)

Beds of Carboniferous Drift in the Bluffs of East Dav- 
Scott County.-Continued.

enport. Tyler McWhorther. (Proc. Davenport Acad. Sci., III, 129-130. 1882.)

Description of New Blastoids from the Hamilton Group. W. H. Barris. (Geol. Sur. Illinois, VII, 357-364. 1883.)

Description of Quaternary deposits. W. H. Pratt. (Proc. Davenport Acad. Sci., I, 96-99. 1876.)

Geological notes. J. D. Whitney. (Geol. Iowa, I, 278-282. 1858.)

Geology of Scott County, Iowa, and Rock Island County, Illinois, and the Adjacent Territory. A. S. Tiffany. (Pamphlet, 1-34, Glass and Hoover, printers, Davenport, 1885.) A short sketch of the geological features.

Local Geology of Davenport. W. H. Barris. (Proc. Davenport Acad. Sci., II, 261-269. 1877.)

New crinoids from Buffalo. A. H. Worthen. (GeoI. Surv. Illinois, VIII, 69-154. 1890.)

New crinoids from the Devonian. F. B. Meek and A. H. Worthen. (Proc. Acad. Nat. Sci., Phila., XVII, 138-143. 1865.)

New Fossils from the Devonian at Davenport. W. 'H. Barris. (Proc. Davenport Acad. Sci., II, 282-288. 1878.)

Notes on our Local Geology, No. II. W. H. Barris. (Proc. Davenport Acad. Sci., III, 163-183. 1882.) Reference to coal. C. A. White. (Geol. Iowa, II, 274. 1870.) Mere reference to the occurrence of coal in this county.

Section of the Bluff at Sixth Street, Davenport. W. H.

Pratt. (Proc. Davenport Acad. Sci., III, 127-129. 1881.) 
Section of the Maquoketa Shales in Iowa. J. F. James. (Proc. Am. As. Ad. Sci., XXXVII, 250-251. 1890.)

Second Annual Report of the State Geologist on the Geological Survey of the State of Iowa. C. A. White. (Pamphlet, 81-284. 1868.)

Second Biennial Report of the State Mine Inspector for the years 1884-1885. P. C. Wilson. (Pamphlet, 1-116. 1885.)

Sedentary Habits of Platyceras. C. R. Keyes. (Am. Jour. Sci., (3), XXXVI, 262-272. 1882.)

Sheppard, Charles Upham. Fall of Meteoric Stones in Iowa. (Am. Jour. Sci., (2), vol. IV, pp. 288-289. New Haven, 1847.) Description of the fragments which fell in Linn county, February 25, 1847.

Sheppard, Charles Upham. Report on Meteorites. (Am. Jour. Sci., (2), vol. VI, pp. 402-417. New Haven, 1848.) Additional notes on the Linn county fall, with chemical analyses and remarks.

Shelby County.

General description. O.H. St. John. (Geol. Iowa, II, 171-174. 1870.) The surface features briefly described.

Shimek, B. Notes on the Fossils of the Loess at Iowa City. (Am. Geologist, vol. I, pp. 149-152. Minneapolis, 1888.) Brief notes on various species of gasteropods found in the loess at Iowa City.

Shimek, B. The Loess and its Fossils. (Bul. Lab. Nat. Hist. State Univ. Iowa, vol. I, pp. 200-214. Iowa City, 1890.) An annotated catalogue of the species of mollusks found in the loess of Iowa. .

Shimek, B. The Loess and its Fossils. (Bul. Lab. Nat. Hist. State Univ. Iowa, vol. II, pp. 89-98. Iowa City, 1890.) Additional notes on fossils found in the form- 
Shimek, B.-Continued. ation, with a general discussion of the climatic conditions during the deposition of the loess.

Shumard, B. F. A Catalogue of the Paleozoic Fossils of North America. (Trans. Acad. Sci., St. Louis, vol. II, pp. 334-407. St. Louis, 1866.) A large number of echinoderms noted from Iowa rocks.

Shumard, B. F. Description of New Fossil Crinoidea from the Paleozoic Rocks of the Western and Southern Portions of the United States. (Trans. Acad. Sci., St. Louis, vol. I, pp. 71-80. St. Louis, 1858.) Describes Actinocrinus multiradiatus as new and gives Iowa as one of the localities.

Shumard, B. F. Description of New Species of Blastoidea from the Paleozoic Rocks of the Western States, with some Observations on the Structure of the Summit of the Genus Pentremites. (Trans. Acad. Sci., St. Louis, vol. I, pp. 238-248. St. Louis, 1858.) In the table of species on pages $245-247$ are a number of species noted from Iowa.

Shumard, B. F., D. D. Owen and. Description of One New Genus and Twenty-two New Species of Crinoidea from the Subcarboniferous Limestone of Iowa. (Rep. Geol. Sur. Wis., Iowa and Minn., App., art. ii, pp. 587-598, with plates. Philadelphia, 1852.) See D. D. Owen and B. F. Shumard, 1852.

Shumard, B. F., D. D. Owen and. On the Number and Distribution of Fossil Species in the Paleozoic Rocks of Iowa, Wisconsin and Minnesota. (Proc. Am. As. Ad. Sci., vol. V, p. 235. 1851.) See D. D. Owen and B. F. Shumard, 1851.

\section{Silurian.}

Brief general account. W. J. McGee. (U. S. Geol. Sur., 11th Ann. Rep., 323-331. 1892.) 
Silurian.-Continued.

Correlation of the Maquoketa shales. J. F. James. (Am. Geologist, V, 335-356. 1890.)

Description of Lower Magnesian limestone. D. D. Owen. (Rep. Geol. Sur. Wis., Iowa and Minn., 58-69. 1852.)

Description of new trilobites. D. D. Owen. (Rep. Geol. Sur. Wis., Iowa and Minn., App., art. i, 573577. 1852.)

Description of St. Peter sandstone. D. D. Owen. (Rep. Geol. Sur. Wis., Iowa and Minn., 69-71. 1852.)

Fossils in Iowa drift. C. A. White. (Geol. Iowa, I, 98. 1870.)

Fossils mentioned from Iowa localities. R. P. Whitfield. (Geol. Sur. Wisconsin, IV, 163-349. 1882.) Fossils from Lower Magnesian limestone. S. Calvin. (Am. Geologist, X, 144-148. 1892.)

Galena limestones correlated with the Utica slate. G.

D. Walcott. (Trans. Albany Inst., X, Adv. Sheets, 1-17. 1879.)

General description. C. A. White. (Geol. Iowa, I, 182184. 1870.) (See Niagara Limestone.)

Its general Characters. C. A. White. (Geol. Iowa, I, 171-180. 1870.) See also Potsdam limestone, St. Peter sandstone, Magnesian limestone, Trenton limestone, Galena limestone and Maquoketa shales. New species of Palaeozoic Fossils. S. Calvin. (Bul. Lab. Nat. Hist. State Univ.-Iowa, I, 177-178. 1890.) Notes Explanatory of a Section from Cleveland, Ohio, to the Mississippi River. J. Hall. (Trans. As. Am. Geologists and Naturalists, 267-293. 1843.). Incidental references to the geology of Iowa. 
Silurian.-Continued.

Pockets of fire-clay in Niagara limestone. P. J. Farnsworth. (Am Geologist, II, 331-334. 1888.)

Rocks of this age recognized in northeastern Iowa: $J$.

N. Nicollet. (Sen. Doc., 26 Cong., 2nd Sess., V. pt. ii, No. 237. 1841.)

Section of the Makoqueta shales in Iowa. J. F. James. (Proc. Am. As. Ad. Sci, XXXVII, 250-251. 1890.) Silurian (Lower.)-(See Silurian.)

Silurian (Upper.)-(See Silurian.)

Sioux County.

General description. C. A. White. (Geol. Iowa, II, 229-232. 1870.) Brief reference to the geology. Sioux Quartzite.

Boulders in Western Iowa. C. A. White. (Proc. Am. As. Adv. Sci., XVII, 340-342. 1869.)

General description. C. A. White. (Geol. Iowa, I, 167-171. 1870.) Its lithological characters, and economic value described.

In Lyon County. C. A. White. (Geol. Iowa, II, 228. 1870.)

Investigation of the Archaean of the Northwestern States. R. D. Irving. (U. S. Geol. Sur., 5th Ann. Rep., 175-242. 1885.)

Occurrence of eruptive rocks noticed. C. R. Keyes. (Proc. Iowa Acad. Sci., I. pt. iii, 19-22. 1893.)

Sketch Map of the State of Iowa. C. A. White. (Geol. Mag., VIII, 222. 1871.)

Sketch of the Geology of Southwestern Iowa. C. A. White. (Am. Jour. Sci., (2) XLIV, 23-31. 1867.) Sketch of the Physical Geography of Iowa. R. E. Call. (Ann. Rep. Iowa Weather and Crop Service, 12-18. 1881.) 
Smith, J. A. Report of the Mine Inspector of the Second District. (Third Biennial Report of the State Mine Inspectors, 1886-1887, pp. 81-112. Des Moines, 1888.) - A list of the mines and their location, with short Soil. accounts of their operations in central Iowa.

History of the Drift Deposits of Iowa. J. E. Todd. (Proc. Iowa Hort. Soc., XVIII, 316-327. 1883.)

Geology and Soils. J. E. Todd. (Proc. Iowa Hort. Soc., XVI, 208-213. 1881.)

Observations on Prairie Soil. W. H. Herrick. (Proc. Iowa Acad. Sci., 1875-80, 16. 1880.)

Of the Prairies. W. H. Herrick. (Proc. Iowa Acad. Sci., 1875-80, 16. 1880.)

Relations of Geology and Agriculture. W. J. McGee.

(Proc. Iowa State Hort. Soc., XVI, 227-240. 1884.)

The Soils of Iowa and their Origin. C. A. White.

(Rep. Sec. Iowa State Agric. Soc., 245-267. 1865.) Soleniscus : its Generic Characters and Relations. C. R.

Keyes. (Am. Naturalist, XXIII, 420-429. 1889.)

Some Additional Observation on the Loess in and about Muscatine. 户. M. Witter. (Proc. Iowa Acad. Sci., 1887-9, 45. 1890.)

Some Dark Shales recently Discovered below the Devonian Limestone, at Independence, Iowa; with a Notice of its Fossils and Deseription of New Species. S. Calvin. (Bul. U. S. Geol. and Geog. Sur. Terr., IV, 725730. 1878.)

Some Geological Features near Muscatine. F. M. Witter. (Proc. Iowa Acad. Sci., 1875-80, 16. 1880.)

Some Geological Problems in Muscatine County, Iowa, with Special Reference to the Rectification of the Supposed Kinderhook, near the Mouth of Pine Creek. S. Calvin. (Am. Geologist, III, 25-36. 1889.) 
Some Geological Problems in Muscatine County. S. Calvin. (Bul. Lab. Nat. Hist. State Univ., I, 7-18. 1888.)

Some New Species of Palæozoic Fossils. S. Calvin. (Bul. Lab. Nat. Hist. State Univ. Iowa, I, 173-181. 1890.)

Sphærodoma: a Genus of Fossil Gasteropods. C. R. Keyes. (Proc. Acad. Nat. Sci., Phila., 303-309. 1889.) Sponges.

Description of new species from Iowa rocks. F. B. Meek and A. H. Worthen. (Geol. Sur. Illinois, II, 143-411. 1866.)

New species from Iowa. E. O. Ulrich. (Geol. Sur. Illinois, VIII, 243-251. 1890.)

New species from the Devonian. J. Hall and R. P. Whitfield. (New York State Cab. Nat. Hist., 23d Ann. Rep., 223-239. 1873.)

Sponges of the Devonian and Carboniferous Systems. E. O. Ulrich. (Geol. Sur. Illinois, VIII, 243-251. 1890.)

Springs.

General remarks. C. A. White. (Gieol. Iowa, I, 7880. 1870.) Brief account of the springs of the state.

Springs (Salt).

In Iowa. C. A. White. (Geol. Iowa, II, 334-336. 1870.)

Springer, Frank, Charles Wachsmuth and. New Species of Crinoids and Blastoids. (Geol. Sur. Illinois, vol. VIII, pp. 157-251. Springfield, 1890.) See Charles Wachsmuth and Frank Springer, 1890.

Springer, Frank, Charles Wachsmuth and. Revision of the Palæocrinoidæ, Part I. (Proc. Acad. Nat. Sci., 
Springer, Frank, etc.-Continued.

Phila., 1879, pp. 226-379. Philadelphia, 1879.) See

Charles Wachsmuth and Frank Springer, 1879.

Springer, Frank, Charles Wachsmuth and. Revision of the Palacocrinoidæe, Part II. (Proc. Acad. Nat. Sci., Phila., pp. 177-414. Philadelphia, 1881. See Charles Wachsmuth and Frank Springer, 1881.

Springer, Frank, Charles Wachsmuth and. Revision of the Palæocrinoidæ, Part III, Section 1. (Proc. Acad. Nat. Sci., Phila., 1885. pp. 225-364. Philadelphia, 1885.) See Charles Wachsmuth and Frank Springer, 1885.

Springer, Frank, Charles Wachsmuth and. Revision of the Palæocrinoidæ, Part III, Section 2. (Proc. Acad. Nat. Sci., Phila., 1886, pp. 64-226. Philadelphia, 1886.) See Charles Wachsmuth and Frank Springer, 1886.

Springer, Frank, Charles Wachsmuth and. Transition Forms in Crinoids and Descriptions of Five New Species. (Proc. Acad. Nat. Sci., Phila., pp. 224-266.) See Charles Wachsmuth and Frank Springer, 1878.

Statistics in Regard to Iowa Coal Product. J. H. Jones. (Rep. Mining Industry in the United States at the 11th Census, 1890, 343-422. 1892.)

Stereocrinus, Barris. W. H. Barris. (Proc. Acad. Sci., Davenport, IV, 102-104. 1885.)

St. John, O. H. Geology of the Middle Region of Western Iowa. (Second Ann. Rep. State Geologist, pp. 191-201. Des Moines, 1868.) A popular description of the geology of western Iowa.

St. John; O. H. Geology of the Middle Region of Western Iowa. (Geol. Iowa, vol. II, pp. 1-200. 1870.) A general description of the physical features and geology 
St. John, O. H.-Continued.

of the middle regions of western Iowa. The special geology of the following counties also described, with sections :

Dallas county.

Warren county.

Lucas county.

Guthrie county.

Greene county.

Carroll county.

Calhoun county.

Sac county.

Ida county.

Audubon county.

Crawford county.

Shelby county.

Harrison county.

Monona county.

Woodbury county.

St. John, O. H. Middle Coal Measures. (Geol. Iowa, vol. I, pp. 264-284. 1870.) This forms Chapter IV of the Geology of Iowa and treats at length of the surface features, geological structure and of the region underlaid by the middle Coal Measures. A general section of the middle Coal Measures and a detailed description of the different beds are also given.

St. John, O. H. Report of the Assistant State Geologist. (Second Ann. Rep. State Geologist, pp. 84-87. Des Moines, 1868.) A short statement of the work done. St. John, O. H. Surface Geology of the Raceon River Region. (Second Ann. Rep. State Geologist, 173-190. Des Moines, 1868.) A popular sketch of the geological features of the region. 
St. John, O. H., C. A. White and. Descriptions of New Subcarboniferous and Coal Measure Fossils, collected upon the Geological Survey of Iowa, together with notice of new generic characters observed in two Species of Brachiopods. (Trans. Chicago Acad. Sci., vol. I, pp. 115-127, figs. 1-12. Chicago, 1867.) See C. A. White and O. H. St. John, 1867.

St. John, O. H., G. A. White and. Preliminary Notice of New Genera and Species of Fossils. (Pamphlet, pp. 1-4. Iowa City, 1867.) See C. A. White and O: H. St. John, 1867.

St. John, O. H., A. H. Worthen and. Description of Fossil Fishes. (Geol. Sur. Illinois, vol. VI, pp. 245-288, with plates. Springfield, 1875.) A large number of species described as new from Iowa rocks.

St. John, O. H., and A. H. Worthen. Description - of Fossil Fishes. (Geol. Sur. Illinois, vol. VII, pp. 53-264, with plates. Springfield, 1883.). A number of species from Iowa described as new.

St. Louis Limestone.

Analyses of lime. J. D. Whitney. (Geol. Iowa, I, 379-383. 1858.)

Brachiopods mentioned from Iowa. R. P. Whitfield.

(Bul. Am. Mus. Nat. Hist., I, 39-97. 1882.)

Brecciated Character of the St. Louis Limestone. C.

H. Gordon. (Am. Naturalist, XXIV, 305-313. 1890.)

Classification of the Lower Carboniferous. Rocks of the

Mississippi Valley. C. R. Keyes. (Washington: Judd and Detweiller, printers, 1-24. . 1892.) Sections and details of the rocks in southeastern Iowa. Description of fossil fishes. O. H. St. John and A. .H. Worthen. (Geol. Sur. Illinois, VII, 53-264. 1883.) 
St. Louis Limestone.-Continued.

Description of Iowa fossils. James Hall. (Geol. Iowa, I, 667-677. 1858.)

Description of new fossils. A. H. Worthen. (Geol. Surv. Illinois, VIII, 69-154. 1890.)

Description of new species of fishes. O. H. St. John and A. H. Worthen. (Geol. Sur. Illinois, VI, 245288. 1875.)

Description of new species of fossils. C. A. White. (Proc. Bost. Soc. Nat. Hist., IX, 8-33. 1865.)

Description of new species of fossils from Iowa rocks. F. B. Meek and A. H. Worthen. (Geol. Sur. Illinois, II, 143-411. . 1866.)

General description. C. A. White. (Geol: Iowa, I, 215-222. 1870.) Its general characters and economic value briefly described.

General description of the characters. James Hall. (Geol. Iowa, I, 98-106. 1858.)

In Des Moines county. A. H. Worthen. (Geol. Iowa, I, 201. 1858.)

In Henry county. A. H. Worthen. (Geol: Iowa, I, 215-216. 1858.)

In Jefferson county. A. H. Worthen. (Geol. Iowa, I, 236-237. 1858.)

In Lee county. A.H.Worthen. (Geol. Iowa, I, 190191. 1858.)

In Van Buren county. A. H.Worthen. (Geol. Iowa, I, 226-227. 1858.)

In Wapello county. A. H. Worthen. (Geol. Iowa, I, 254-255. 1858.)

In Washington county. A. H. Worthen. (Geol. Iowa, I, 242-243. 1858.)

New Bryozoans. E. O. Ulrich. (Geol. Sur. Illinois, VIII, 283-688. 1890.) 
St. Louis Limestone.-Continued.

New species of fossils from Iowa. C. A. White. (Twelfth Ann. Rep. U. S. Geol. and Geog. Sur. Terr., 155-171. 1883.)

Of Iowa. W. J. McGee. U. S. Geol. Sur., Eleventh Ann. Rep., 312. 1892.) Brief mention.

Principal Mississippian Section. C. R. Keyes. (Bul. Geol. Soc. America, III, 283-300. 1892.) The recent investigations'along the Mississippi river and the stratigraphical details described with a proposed new classification of the lower Carboniferous rocks in the Mississippi basin.

Unconformibility of the St. Louis limestone upon the older formations of the Sub-Carboniferous group. C. A. White. (Geol. Iowa, I, 225-230. 1870.)

Stones. W. C. Day. (Rep. of the Mining Industry in the United States at the 11th Census in 1890, pp. 593-666. 1892.)

\section{Story County.}

General reference to the geology. G. A. White. (Geol. Iowa, II, 259-260. 1870.)

Stout, Jas. A. Report of the Mine Inspector of the Third District. (Third Biennial Report State Mine Inspectors, pp. 113-177. Des Moines, 1888.) A list of the mines in north-central Iowa, with short accounts of their operations.

Stout, J. A. Report of the Mine Inspector of the Third District. (Fourth Biennial Report of the State Mine Inspectors, 1888-89, pp. 115-151. Des Moines, 1889.) List of mines with short accounts of their operations. Stratigraphy of the Carboniferous in Central Iowa. C. R. Keyes. (Bul. Geol. Soc. America, II, 277-292. 1891.) 
Structure and Probable Affinities of Cerionites dactylioides. Owen. S. Calvin. (Proc. Iowa Acad. Sci., I, pt. iii, pp. 13-15. 1893.)

St. Peter Sandstone.

Chemical Analyses. J. D. Whitney. (Geol. Iowa, I, 337-340. 1858.)

Description of this formation in northeastern Iowa. D. D. Owen. (Rep. Geol. Sur. Wis., Iowa and Minn., 69-71. 1852.)

General description of the characters. James Hall. (Geol. Iowa, I, 52-54. 1858.)

Of northeastern Iowa. (W. J. McGee. U. S. Geol. Sur., Eleventh Ann. Rep., 330-331. 1892.)

Surface Deposits.-(See Quaternary.)

Surface Features.

Of eastern Iowa. W. J. McGee. (Bul. Phil. Soc. Washington, VI, 93-97. 1883.)

Of eastern Iowa. W. J. McGee. (Pamphlet, 1-14. Ft. Dodge, 1884.)

Sketch of the Physical Geography of Iowa. R. E. Gall. (Ann. Rep. Iowa Weather and Crop Service, 12-18. 1891.)

Surface Geology of Burlington, Iowa. C. R. Keyes. (Am. Naturalist, XXII, 1049-1054. 1888,)

Surface Geology of the Raccoon River Region. O. H. St. John. (Second Ann. Rep. State Geologist, 173-190. 1868.)

Synopsis of American Carbonic Calyptræidæ. C. R. Keyes. (Proc. Acad. Nat. Sci., Phila., 1890, 150-181. 1890.)

Table of Altitudes. H. Gannett. U. S. Geol. Sur., Bul: No. 5, Iowa, 105-112. 1884.) 


\section{Tama County.}

Geological notes. J. D. Whitney. (Geol. Iowa, I, 266-273. 1858.)

Taylor County.

General geological description. C. A. White. (Geol. Iowa, I, 344-348. 1870.) A brief account of its surface features and geology.

Brief reference to the geology. C. A. White. (First Ann. Rep. State Geologist, 45-47. 1868.)

Terminal Moraine of the Second Glacial Epoch. T. C. Chamberlin. (U:S. Geol. Sur., Third Ann. Rep., 291404. 1883.)

Terrane cretace des environs de Sioux City. J. Marcou. (Bul. Soc. géol. de France, (2), t. XXIV, p. $56 . \quad$ 1866.) Thomas, Morgan G. Report of the Mine Inspector for the Third District. (Fifth Biennial Report State Mine Inspectors, 1890-1891, 95-141. Des Moines, 1891.) Short accounts of the various mines, borings and improvements during the preceding two years.

Tiffany, A. S. Geology of Scott County, Iowa, and Rock Island County, Illinois and the Adjacent Territory. (Pamphlet, pp. 1-34, Glass and Hoover, printers. 1885.) A general account of the different geological formations in the vicinity of Davenport, with lists of fossils found in each horizon.

Tiffany, A. S. The Artesian Well at City Park, Davenport. (Am. Geologist, vol. III, pp. 117-118. Minneapolis, 1889.) A section of the boring at Davenport, with the different rocks referred to their geological ages.

Tilton, J. L. Strata Between Ford and Winterset. (Proc. Iowa Acad. Sci., vol. I, pt. iii, pp. 26-27. Des Moines, 1893.) The section along Middle river in Madison and Warren counties described. 
Todd, J. E. A History of the Drift Deposits of Iowa. (Proc. Iowa Hort. Soc., vol. XVIII, pp. 316-327. Des Moines, 1883.) The different kinds of drift soil distinguished and their origins described.

Todd, J. E. Annual Deposits of the Missouri River During the Post-Pliocene. (Proc. Am. As. Ad. Sci., vol. XXVI, pp. 287-291. Salem, 1877.)

Todd, J. E. Evidence that Lake Cheyenne Continued till the Ice Age. (Proc. Am. As. Ad. Sci., vol. XXXVII, pp. 202-203. Salem, 1889.) . Evidence brought forth to show that western Iowa and eastern Nebraska were occupied by a fresh water lake before the deposition of the drift. Claw of Megalonyx found in Mills county.

Todd, J. E. Geology and Soils. (Proc. Iowa Hort. Soc., vol. XVI, pp. 208-213. Des Moines, 1881.) Describes the dependence of soil on underlying rocks.

Todd, J. E. Loess and its Soils. (Proc. Iowa Hort. Soc., vol. XVII, pp. 263-270. Des Moines, 1882.) A popular discussion of the properties of the bluff soil. Todd, J. E. Notes on the Distribution of Timber in Southwestern Iowa, with Inferences Concerning the Origin of Prairies. (Am. Naturalist, vol. XII, pp. 9196. Philadelphia, 1878.) Facts in southwestern Iowa examined in the light of the different theories concerning the origin of the prairies.

Todd, J. E. On the Folding of Carboniferous Strata in Southwestern Iowa. (Proc. Iowa Acad. Sci., 18871889, p. 58. Des Moines, 1890.) Abstract of a paper read before the Academy, with general section of the upper Carboniferous rocks in southwestern Iowa.

Todd, J. E. On the Relation of the Loess to Drift in Southwestern Iowa. (Proc. Iowa Acad. Sei., 1875-80, 
Todd, J. E.-Continued.

p. 19. Iowa City, 1880.) A general section of the surface deposits of southwestern Iowa given.

Todd, J. E. On the Roots and Root-marks found in the Loess. (Proc. Iowa Acad. Sci., 1875-80, 17. Iowa City, 1880.) Abstract of a paper read before the Academy.

Todd, J. E. Recent Wind Action upon the Loess. (Proc. Iowa Acad. Sci., 1875-80, p. 21. Iowa City, 1880.) Abstract of a paper read before the Iowa Academy of Science, June 24, 1880.)

Todd, J. E. Richthofen's Theory of the Loess in the Light of the Deposits of the Missouri. (Proc. Am. As. Ad. Sei., vol. XXVII, pp. 231-239. Salem, 1878.) Todd, J. E. The Charcoal Streak in the Loess. (Proc. Iowa Acad. Sci., 1875-1880, p. 21. Iowa City, 1880.) Abstract of a paper read before the Iowa Academy of Sciences, June 24, 1880.

Topography.

General topography of Iowa. C. A. White. (Geol. Iowa, I, 29-35. 1870.) . General features, with tables of elevations, and profiles across the state.

Of Iowa. J. D. Whitney. (Geol. Iowa, I, 1-8. 1858.) Of northeastern Iowa. W. J. McGee. (U. S. Geol. Sur., 11th Ann. Rep., 180-377. 1892.)

Table of Altitudes. H. Gannett. (U. S. Geol. Sur., Bul. No. 5, Iowa, 105-112. 1884.)

Topographic Types of Northeastern Iowa. . W. J. McGee. (Proc. Am. As. Ad. Sci., XXXVII, 248-249. 1890.)

Topographic Types of Northeastern Iowa. W. J. McGee. (Proc. Am. As. Ad. Sci., XXXVII, 248-249. 1890.) 
Torrey, Joseph, Jr., and E. H. Barbour. The Recorded Meteorites of Iowa, with Special Mention of the Last or Winnebago County Meteorite. (Am. Geologist, vol. VIII, pp. 65-72. Minneapolis, 1891.) Notice of a meteorite that fell in Iowa.

Torrey, Jóseph, Jr., and E. H. Barbour. The Winnebago County (Iowa) Meteorites. (Science, vol. XV, p. 347. 1890.) Reference to a fragment supposed to be a piece of meteorite. The authors claim it was not and base their claims on the grounds of: Two low specific gravity, absence of metals and external crust, and chemical analysis.

Transition Forms in Crinoids and Deseription of Five New Species. Charles Wachsmuth and Frank Springer. (Proc. Acad. Nat. Sci., Phila., 224-226. 1878.)

Transitional Drift. Glement L. Webster. (Am. Naturalist, vol. XXIV, pp. 1182-1185. 1890.)

\section{Trenton Limestone.}

Chemical analyses. J. D. Whitney. (Geol. Iowa, I, 341-349. 1858.)

General description. C. A. White. (Geol. Iowa, I, 174-176. 1870.) Its general characters, economic value and fossils briefly described.

General description of the characters. James Hall. (Geol. Iowa, I, 54-60. 1858.)

Of northeastern Iowa. W. J. McGee. (U. S: Geol. Sur., 11th Ann. Rep., 329-330. 1892.)

\section{Trilobites.}

Description of new species. D. D. Owen. (Rep. Geol. Sur. Wis., Iowa and Minn., App., art. i, 573577. 1852.) 
Ulrich, E. O. Paleozoic Bryozoa. (Geol. Sur. Illinois, vol. VIII, pp. 283-688, with plates. Springfield, 1890.) A number of species from Iowa described as new.

Ulrich, E. O. Sponges of the Devonian and Carboniferous Systems. (Geol. Sur. Illinois, vol. VIII, pp. 243251. Springfield, 1890.). Two species from Iowa described as new.

\section{Union County.}

General description of geology. C. A. White. (Geol. Iowa, I, 330-335. 1870.) A brief account of its general character and geology.

Reference to its surface features. C. A.White. (First Ann. Rep. State Geologist, 69-70. 1868.)

Utica Slate and Related Formations of the Same Geological Horizon. C. D. Walcott. (Trans. Albany Inst., $\mathrm{X}$, Advance Sheets, 1-17. 1879.)

\section{Van Buren County.}

Brief geological notes. C. A. White. (Second Ann. Rep. State Geologist, 112-117. 1868.)

Coal. C. A. White. (Geol. Iowa, II, 271-273. 1870.) General geological description. A. H. Worthen. (Geol. Towa, I, 219-230. 1858.) A brief detailed account of the geological formations.

Variation Exhibited by a Carbonic Gasteropod. C. R. Keyes. (Am. Geologist, III, 329-333. 1889.)

Vermes.-(See Worms).

Verneuil, Ed. de. Note sur le parallésme des roches des dépots paléozoiques de l'Amerique Septentrionale avec ceux de l'Europe, suivie d'un tableau des éspeces fossiles commones aux deux Continents, avec l'indication des étages on elles as recontrent, et terminée par un examen critique de chacune de ces éspeces. (Bul. Soc. 
Verneuil, Ed. de.-Continued.

géol. de France, (2), t. IV, pp. 646-710. Paris, 1847.)

Incidental references bearing upon the geology of Iowa.

\section{Vertebrates.}

Bones of the Mammoth in Washington County, Iowa.

J. Gass and W. H. Pratt. (Proc. Davenport Acad. Nat. Sci., III, 177-178. ' 1882.)

Description of new species of fishes. J. S. Newberry and A. H. Worthen. (Geol. Sur. Illinois, II, 9-134. 1866.)

Description of new species of fishes from the Iowa lower Carboniferous rocks. O. H. St. John and A. H. Worthen. (Geol. Sur. Illinois, VI, 245-288. 1875.)

Fossil Faunas in Central Iowa. C. R. Keyes. (Proc. Acad. Nat. Sci., Phila, 242-265. 1891.) Notes and bibliographic references of the species found in the lower Coal Measures of the central part of the state. Fossil Remains of a Caribou. J. Leidy. (Proc. Acad. Sci., Phila., XXXI, 32-33. 1879.

From eastern Nebraska. F. B. Meek. (Final Report U. S. Geol. Sur. Nebraska, pt. ii, 83-245. 1872.)

New species of fishes from the Iowa Carboniforous. J. S. Newberry and A. H. Worthen. (Geol. Sur. Illinois, IV, 246-374. 1870.)

Occurrence of fish remains in the Carboniferous limestone. A. H. Worthen. (Proc. Am. As. Ad. Sci., $\mathrm{X}$, 189-192. 1856.)

Of Central Iowa. C. R. Keyes. (Proc. Acad. Nat. Sci., Phila., 231-247. 1888.)

Volcanic Eruption in Iowa. C. R. Keyes. (Science, XXI, 132. 1893.) 
Wachsmuth, Charles. Preliminary Notice of the Sphæroidocrinoidæ. (Proc. Iowa Acad. Sci., 1875-80, p. 22. Iowa City, 1880.) Abstract of a paper read before the Iowa Academy of Science June 24, 1880.

Wachsmuth, Charles, W. H. Niles, and. Evidence of the Two Distinct Geological Formations in the Burlington Limestone. (Am. Jour. Sci., (2), XLII, 95-99. 1866.) See W. H. Niles and Charles Wachsmuth. 1866.

Wachsmuth, Charles, and Frank Springer. Discovery of the Ventral Structure of Taxocrinus and Haplocrinus; and Consequent Modifications in the Classification of the Crinoidea. (Proc. Acad. Nat. Sci., Phila., 1888, pp. 337-363. 1888.) Remarks upon the classification of the crinoidea necessitated by the recent discovery of the ventral structure of certain crinoids from the Kinderhook [of Marshall County, Iowa.]

Wachsmuth, Charles, and Frank Springer. New Species of Crinoids and Blastoids. (Geol. Sur. Illinois, vol. VIII, pp. 157-251. Springfield, 1890.) A short sketch of the geology of LeGrand; with a number of species from Marshall county described as new.

Wachsmuth, Charles, and Frank Springer.. Revision of the Palæocrinoidæ, Part I. (Proc. Acad. Nat. Sci., Phila., 1879, pp. 226-379. Philadelphia, 1879.) The cridoids of Iowa listed; with localities.

Wachsmuth, Charles, and Frank Springer. Revision of the Palæocrinoidæ, Part II. (Proc. Acad. Nat. Sci., Phila, 1881, pp. 177-414. Philadelphia, 1881.) The crinoids of Iowa listed, with localities.

Wachsmuth, Charles, and Frank Springer. Revision of the Palæocrinoidæ, Part III, Section 1. (Proc. Acad. Nat. Sci., Phila., 1885, pp. 225-364. Philadelphia, 1885.) The crinoids of Iowa listed, with localities. 
Wachsmuth, Charles, and Frank Springer. Revision of the Palæocrinoidæ, Part III, Section 2. (Proc. Acad. Nat. Sci., Phila., 1886, pp. 64-226. Philadelphia, 1886.) The crinoids of Iowa listed, with localities.

Wachsmuth, Charles, and Frank Springer. The Perisomic Plates of the Crinoids. (Proc. Acad. Nat. Sci., Phila., 1890, pp. 345-292, 2 plates. 1890.) Incidental reference and figures of crinoids from Iowa.

Wachsmuth, Charles, and Frank Springer. Transition Forms in Crinoids, and Description of Five New Species. (Proc. Acad. Nat. Sci., Phila., 1878, pp. 224-266. Philadelphia, 1878.) An account of the evolution of certain of the lower Carboniferous crinoids of the Mississippi basin, with special reference to those found in Iowa. Several species described from Iowa as new.

Walcott, Charles D. Correlation Papers: Cambrian. (U. S. Geol. Sur., Bul. 81, pp. 1-447. Washington, 1891.) A review of the literature relating to the Potsdam rocks of the state, pp. 187-188. Discussed also in the general summary of the Cambrian rocks of the interior basin.

Walcott, C. D. The Utica Slate and Related Formations of the same Geological Horizon. (Trans. Albany Inst., vol. X, Adv. Sheets, pp. 1-17. Albany, 1879.) Galena limestone correlated with the Utica slate.

Wallace, Samuel J. Memorandum of a Fossil Wood from the Keokuk Formation, Keokuk, Iowa. (Am. Jour. Sei., (3), vol. XV, p. 396. New Haven, 1878.) Notice of a piece of wood three feet long from the limestone.

Wapello County.

Analyses of coal. Rush Emery. (Geol. Iowa, II, 376385. 1870.) 
Wapello County.-Continued.

Artesian well at Ottumwa. G. H. Gordon. (Am. Geologist, IV, 237-239. 1889.) Section given.

Brief notes on its geology. C. A. White. (Second Ann. Rep. State Geologist, 108-112. 1868.)

Coal. C. A. White. (Geol. Iowa, II, 268-270. 1870.)

Reference to a number of coal mines in the county.

General geological description. A.H.Worthen. (Geol.

Iowa, I, 248-258. 1858.) Brief description of the geological features.

Ward, Lester F. Geological Distribution of .Fossil Plants. (U. S. Geol. Sur., 8th Ann. Rep., pp. 663933. Washington, 1889.) Some Iowa localities are given on pages $895-896$.)

Warren County.

Analyses of coal. Rush Emery. (Geol. Iowa, II, 385386. 1870.)

Description of the general geological features. $0 . \mathrm{H}$. St. John. ' (Geol. Iowa, II, 46-77. 1870.) The Geological features of the county briefly described with numerous sections given in detail.

Strata between Ford and Winterset. J. L. Tilton. (Proc. Iowa Acad. Sci., I, pt. iii, pp. 26-27. 1893.) Warsaw Limestone.

General description of the characters. James Hall. (Geol. Iowa, I, 97-98. 1858.)

In Lee county. A. H. Worthen. (Geol. Iowa, I, 192. 1858.)

\section{Washington County.}

Bones of the Mammoth. J. Gass and W. H. Pratt. (Proc. Davenport Acad. Nat. Sci., III, 177-178. 1882.) 
Washington County.-Continued.

Deep well at Washington. S. Calvin. (Am. Geologist, I, 28-31. 1888.)

General account of the geology. A. H. Worthen. (Geol. Iowa, I, 239-248. 1858.) Brief account of the geological phenomena as shown in the county. Reference to coal. C. A. White. (Geol. Iowa, II, 273. 1870.)

\section{Waters.}

Chemical analyses. G. Hinrichs. (Second Ann. Rep. State Geologist, 233-238. 1868.)

Chemical analyses. Rush Emery. (Geol. Iowa, II, 354-357. 1870.) Artesian well and spring waters. Its relation to health and disease. W. H. Dickinson. (Iowa State Board of Health, First Biennial Rep., 197-227. 1882.)

Of Iowa. C. A. White. (Geol. Iowa, II, 330-331. 1870.)

Wayne County.

Brief notes on the geology. C. A. White. (First Ann. Rep. State Geologist, 40-42. 1868.)

Webster, Clement L. A Description of the Rockford Shales of Iowa. (Proc. Davenport Acad. Nat. Sci., vol. V, pp. 100-109. Davenport, 1887.) A detailed account of the lithological features of the Rockford Shales and their fossils; with sketch-map.

Webster, Clement L. A General Preliminary Description of the Devonian Rocks of Iowa; which Constitutes a Typical Section of the Devonian Formation of the Interior Continental Area of North America. (Am. Naturalist, vol. XXIII, pp. 229-243. Philadelphia, 1889.) General discussion of the Devonian of Iowa. The name "Hackberry Group" proposed for 
Webster, Clement L.-Continued.

the Lime Creek beds. The Devonian divided into Corniferous, Hamilton and Hackberry. Lists of characteristic fossils given.

Webster, Clement L. Contribution to the Knowledge of the Genus Pachyphyllum. (Am. Naturalist, vol. XXIII, pp. 621-625. Philadelphia, 1889.) Three species, without figures, are described as new from the Devonian of Floyd county.

Webster, Clement L. Description of a New Genus of Corals from the Devonian Rocks of Iowa. (Am. Naturalist, vol. XXIII, pp. 710-712. Philadelphia, 1889.) Three genera and two species, without figures, described as new.

Webster, Clement L. Notes on the Geology of Johnson County. (Am. Naturalist, vol. XXII, pp. 408-419. Philadelphia, 1888.) An account of the surface geology, with several illustrations, in the vicinity of Iowa City.

Webster, Clement L. Notes on the Rockford Shales. (Am. Naturalist, vol. XXII, pp, 444-446. Philadelphia, 1888.) Three species are described as new.

Webster, Clement L. On the Glacial Flow in Iowa. (Am. Naturalist, vol. XXI, pp. 758-761. Philadelphia, 1887.) The announcement of the glacial scratches at Iowa City.

Webster, Clement L. Transitional Drift of a Portion of Northern Iowa. (Am. Naturalist, vol, XXIV, pp. 1182-1185. Philadelphia, 1890.)

Webster County.

Analyses of coal. Rush Emery. (Geol. Iowa, II, 375-376. 1870.) 
Webster County.-Continued.

Coal at Ft. Dodge. C. A. White. (Second Ann. Rep. State Geologist, 140-141. 1868.)

Deposits of Gypsum described in detail. C. R. Keyes. (Mon. Rev. Iowa Weather and Crop Service, IV, No. 3, 2-4. 1893.)

Gypsum at Ft. Dodge. C. A. White. (Second Ann. Rep. State Geologist, 135-140. 1868.)

Gypsum deposits. C. A. White. (Geol. Iowa, II, 293. 1870.)

General geological features. C. A. White. (Geol. Iowa, II, 254-256. 1870.)

Reference to the coal and gypsum. C. A. White. (First Ann. Rep. State Geologist, 26-27. 1868.) Wells.

Deep Well at Emmetsburg, Iowa. N. H. Winchell. (Bul. Minnesota Acad. Sci., I, 387-390, 1880.)

Deep Well at Washington, Iowa. S. Calvin. (Am. Geologist, I, 28-31. 1888.)

White, Charles A. A sketch of the Geology of Southwestern Iowa. (Am. Jour. Sci., (2), vol. XLIV, pp. 23-31. New Haven, 1867.) It is shown that the limestones of the region discussed belong to the upper and not to the lower Carboniferous series, as has been supposed by some previous authors.

White, Charles A. Announcement of the Existence of Cretaceous Rocks in Guthrie County, Iowa. (Proc. Am. As. Adv. Sci., vol. XVII, pp. 326-327. Cambridge, 1869.)

White, Charles A. Character of the Unconformability of the Iowa Coal Measure upon OIder Rocks. (Am. Jour. Sci., (2), vol. XLV, pp. 331-334. New Haven, 1868.) A brief announcement of the unconformity of the coal Measures on the Lower Carboniferous rocks. 
White, Charles A. Contributions to Invertebrate Paleontology, No. 8: Fossils from the Carboniferous Rocks in the Interior States. (U. S. Geol. and Geog. Sur. Terr., Twelfth Ann. Rep. 1878, pp. 155-171, pls. xxxiv-xlii. Washington, 1883.) Descriptions of new species of fossils from Iowa included.

White, Charles A. Description of New Species of Fossils from the Devonian and Carboniferous Rocks of the Mississippi Valley. (Proc. Boston Soc. Nat: Hist., vol. IX, pp. 8-33. Boston, 1865.) A number of new species of fossils described as new.

White, Charles A. Description of New Species of Fossils from the Paleozoic Rocks of Iowa. (Proc. Acad. Nat. Sci., Phila., vol. XXVIII, pp. 27-34. Philadelphia, 1877.) Numerous species described as new.

White, Charles A. Drift Phenomena of Southwestern Iowa. (Am. Jour. Sci., (2), vol. XLIV, p. 119. New Haven, 1867.) An additional note to an article of the same title.

White, Charles A. Exogenous Leaves in the Cretaceous Rocks of Iowa. (Am. Jour. Sci., (2), vol. XLIV, p. 119, New Haven, 1867.) A note announeing the discovery of exogenous leaves, and showing that the "Nishnabotna sandstone" is identical with the Dakota group.

White, Charles A. First Annual Report of Progress of the State Geologist. (Pamphlet, pp. 1-4. Des Moines, 1867.) A statement of the work done during the year previous.

White, Charles A. First Annual Report of the State Geologist. (First and Second Annual Report by the State Geologist, on the Geological Survey of the State of Iowa, pp. 5-8. Des Moines, 1868.) A short report 
White, Charles A.-Continued.

of the work carried on during the preceding two years, with reprint of popular letters appearing in the various newspapers of the state.

White, Charles A. Geological Map Model of Iowa. (Geol. Iowa, vol. I, p. 32. Des Moines, 1870.)

White, Charles A. Geological Map of the State of Iowa. (Geol. Iowa, vol. II. Des Moines, 1870.)

White, Charles A. The Iowa Drift. (Am. Naturalist, vol. II, pp. 615-616. Salem, 1869.) Calls attention to the original sites of the granite boulders found in Iowa.

White, Charles A. Lakes of Iowa; Past and Present. (Am. Naturalist, vol. II, pp. 143-155. Salem, 1868.) The drift lakes, including the so-called "walled" lakes are described and the origin of the "walls" explained. Also the bluff deposit of the Missouri river valley is shown to be the deposit of an ancient lake.

White, Charles A. Lakes of Iowa; Past and Present. (Second Ann. Rep. State Geologist, pp. 151-163.' Des Moines, 1868.) A popular description of some of the lakes in Iowa.

White, Charles A. Note on "Cone-in-cone." (Am. Jour.,Sci. (2), vol. XLV, pp.400-401. New Haven, 1868.) The mineral mentioned is from the lower Coal Measures of Iowa.

White, Charles A. Observations on the Red Quartzite Boulders of Western Iowa; and their Original Ledges of Red Quartzite in Iowa, Dakota and Minnesota. (Proc. Am. As. Adv. Sci., vol. XVII, pp. 340-342. Cambridge, 1869.)

White, Charles A. Observations on the Summit Structure of Pentremites, the Structure and Arrangement of Certain Parts of Crinoids, and Description of New 
White, Charles A.-Continued.

Species from the Carboniferous Rocks of Burlington, Iowa. (Boston Jour. Nat. Hist., vol. VII, pp. 481506. Boston, 1863.) Notes on the summit structure of various Pentremites. Several species described as new.

White, Charles A. Observations upon Geology and Paleontology of Burlington, Iowa, and its Vicinity. (Boston Jour. Nat. Hist., vol. VII, pp. 209-235. Boston, 1860.) A detailed description of the rock-section at Burlington, Iowa, with table showing vertical range of the more important fossils. All below the oölite refer to the Chemung (Devonian). Several species are described as new.

White, Charles A. Observations upon the Drift Phenomena of Southwestern Iowa. (Second Ann. Rep. State Geologist, pp. 143-148. Des Moines, 1868.) A short account of the glacial scratches and drift materials.

White, Charles A. Observations upon the Drift Phenomena of Southwestern Iowa. (Am. Jour. Sci., (2), vol. XLIII, pp. 301-305. New Haven, 1867.) Special attention is directed to the glacial striæ upon rocks in situ.

White, Charles A. On Spontaneous Fission ? in Zaphrentis. (Am. Jour. Sci., (3), vol. V, p. 72. New Haven, 1873.) Special reference to specimens from the St. Louis Limestone of Marion county.

White, Charles A. On the Eastern Limit of Cretaceous Deposits in Iowa. (Proc. Am. As. Adv. Sci., vol. XXI, pp. 187-192. Cambridge, 1873.) Cretaceous fossils reported from the drift of Howard, Black Hawk $\therefore$ and Johnson counties. 
White, Charles A. On the Occurrence of Later Cretaceous Deposits in Iowa. (Am. Geologist, vol. I, pp. 221-227. Minneapolis, 1888.) Remarks on certain fossils found in the drift in Hardin county.

White, Charles A. Report of the Geological Survey of the State of Iowa. (Vol. I, pp. i-viii and 1-391. Des Moines, 1870.)

Introduction: Historical statement, popular explanations, and general classification of the Iowa rocks.

PART FIRST (PHYSICAL GEOGRAPIIY AND SURFACE GEOLOGY):

Chapter $I$ is a general account of the surface features of the state: Boundaries, general topography, drainage, springs, etc.

Chapter II forms a general description of the surface deposits of the state, with rather detailed accounts of the composition, distribution and origin of the drift, altered drift, alluvium and bluff deposits (loess).

Chapter III treats of the soils of the drift, loess (bluff) and alluvium; and of the adaptability of the Iowa soils for the growth of the forest trees. . Also an explanation of origin of prairies.

Chapter IV is on the climate of Iowa. (See T. S. Parvin, 1870.)

PART SECOND (GENERAL GEOLOGY).

Chapter I describes the area, general characters, economic value and the fossils of the Archæan, Lower Silurian and Upper Silurian and their general subdivisions.

Chapter II gives an account of the Subcarboniferous; the general characters, economic value and fossils of the Kinderhook, Burlington, Keokuk and St. Louis limestones, together with sections and their minor 
White, Charles A.-Continued.

subdivisions. Remarks also on the unconformability of the Coal Measures upon older rocks and of the St. Louis limestone upon older formations of the Subcarboniferous group.

Chapter III. The lower, middle and upper Coal Measures recognized in their general characters; and their economic value and fossil features described. Also general observations on the Carboniferous rocks of Iowa, with some practical conclusions.

Chapter IV treats of the middle Coal Measures. (See O. H. St. John, 1870).

Chapter V. Earlier Cretaceous, Nishnabotna sandstone, Woodbury shales and Inoceramus beds described; and their areas, lithological character, economic value and fossils noted.

PART THIRD (COUNTY GEOLOGY.)

Chapter I is a general account of the geology of southwestern Iowa, with special descriptions of the geology of the following counties:

Madison.

Clarke.

Decatur.

Ringgold.

Union.

Adair.

Adams.

Taylor.

Page.

Fremont.

Montgomery.

Mills.

Cass.

Pottawattamie. æ G. Rep. 
White, Charles A. Report of the Geological Survey of Iowa. (Vol. II, pp. i-viii and 1-435. Des Moines, 1870.)

PART FIRST (COUNTY GEOLOGY.)

Chapter I deals of the geology of the middle region of western Iowa. (See O. H. St. John; 1870.) The physical features and general geology described, with special reference to the Post-tertiary, Cretaceous and Coal Measures. The general features of the following counties are briefly described, with numerous sections:

Woodbury county.

Monona county.

Harrison county.

Shelby county.

Crawford county.

Audubon county.

Sac county.

Ida county.

Calhoun county.

Carroll county.

Greene county.

Guthrie county.

Dallas county.

Polk county.

Boone county.

Webster county.

Chapter II treats chiefly of Northwestern Iowa. A general description of the geology and material resources; and the geological features of the following counties briefly described:

- Pocạhontas county.

Palo Alto county.

Emmet county. 
White, Charles A.-Continued.

Dickerson county.

Clay county.

Buena Vista county.

Cherokee county.

O'Brien county'.

Osceola county.

Lyon county.

Sioux county.

Plymouth county.

Chapter III describes the middle region of northern Iowa, including the geology of the following counties:

Franklin county.

Wright county.

Gerro Gordo county.

Hancock county.

Worth county.

Winnebago county.

Kossuth county.

Humboldt county.

Chapter IV deals with the geology of the Coal Measures. A few preliminary remarks and a rather full account of the geological features of the following counties are given :

Webster county.

Hamilton county.

Hardin county.

Boone county.

-Story county.

Marshall county.

Polk county.

Jasper county.

Warren county. 
White, Charles A.-Continued.

Marion county.

Mahaska county.

Keokuk county.

Monroe county.

Wapello county.

Appanoose county:

- Davis county.

Van Buren county.

Jefferson county.

PART SECOND (ECONOMIC GEOLOGY.)

Chapter I describes at length the Peat formation of the state; also brief reference to the petroleum.

Chapter II describes in detail the Gypsum deposits and related materials.

Chapter III gives an account of the Building Materials, especially the clays found in the eastern part of the state ; also more or less brief mention of the limestone, fire-clay, road-materials, etc., with brief allusion to the artesian wells and mineral springs.

Chapter IV is chiefly a report of chemical work done by the Survey. (See Rush Emery. 1870). This includes minerals, rocks, lead, clays, coals, waters, and peats.

Appendix $\mathrm{A}$ is a list of railroad elevations by chief engineers of the different railways.

Appendix B is a catalogue of Iowa Birds. (By J. A. Allen.)

Appendix $\mathrm{C}$ is an explanation of land surveys. (By C. W. Irish.)

White, Charles A. Report upon the Invertebrate Fossils Collected in Portions of Nevada, Utah, Colorado, New Mexico and Arizona by Parties of the Expedi- 
White, Charles A.-Continued.

tions of 1871, 1872, 1873 and 1874. (Rep. Geol. and Geog. Expl. and Sur. W. 100 Mer., vol. IV, pp. 1219, pls. i-xxi. Washington, 1875.) A number of species from Iowa described as new.

White, Charles A. Second Annual Report of the State Geologist on the Geological Survey of the State of Iowa. (Pamphlet, pp. 81-284. Des Moines, 1868.) A short sketch of the work done, with reprint of popular letters appearing in the various newspapers.of the state.

White, Charles A. Sketch-Map of the State of Iowa. (Geol. Magazine, (1), vol. VIII, p. 222. London, 1871.)

White, Charles A. The Iowa Drift. (Am. Naturalist, vol. II, pp. 615-616. Salem, 1869.) The derivation of the drift material from the underlying rocks, by their disintegration and comminution, is shown.

White, Charles A. The Soils of Iowa and Their Origin. (Rep. Sec. Iowa State Agric. Soc., 1865, pp. 245-267. 1865.) A popular lecture delivered before the society, September 29, 1865.

White, Charles A., and O. H. St. John. Descriptions of New Subcarboniferous and Coal Measure Fossils, collected upon the Geological Survey of Iowa, together with notice of new Generic Characters observed in two Species of Brachiopods. (Trans. Chicago Acad. Sci., vol. I, pp. 115-127, figs. 1-12. Chicago, 1867.) Fourteen species of fossils described as new from Iowa rocks.

White, Charles A., and O. H. St. John. Preliminary Notice of New Genera and Species of Fossils, by C. A. White and $\mathrm{O}$. H. St. John. (Pamphlet, pp. 1-3. Iowa City, 1867.) 
White, Charles A., and R. P. Whitfield. Observations upon the Rocks of the Mississippi Valley which have been Referred to the Chemung Group of New York, together with Descriptions of new Species of Fossils from the same Horizon at Burlington, Iowa. (Proc. Boston Soc. Nat. Hist., vol. VII, pp. 289-316. Boston;1862.) Several species are described as new from Iowa.

Whitfield, R. P. Description of a New Species' of Crinoid from the Burlington Limestone, at Burlington, Iowa. (Bul: Am. Mus. Nat. Hist, , vol. I, pp. 7-9. New York, 1881.) Poteriocrinus jesipi described and figured as new.

Whitfield, R: P. On the Fauna of the Lower Carboniferous Limestones of Spergen Hill; Ind., with a Revision of the Descriptions of its Fossils hitherto Published; and Illustrations of the Species from the Original Type Series. (Bul, Am. Mus. Nat. Hist., vol. I, pp: 39-97, with plates. New York, 1882:) A number of the species reported from Iowa localities.

Whitfield, R. P. Paleontology of :Wisconsin (Geol: Sur. Wisconsin, vol. "IV, 'pp." 163-349, with plates. Madison; 1882.) A number of species of fossils from

. Iowá localities noted.

Whitfield, R. P., and J. Hall. Description of New Species of Fossils from the Devonian Rocks of Iowa. (New York State Cab. Nat. Hist., 23d Ann. Rep., pp. 223-239. Albany, 1873.)

Whitney, J. D. Chemistry and Economical Geology. (Geol. Iowa, I, 324-472. Albany, 1858:) A mention of the chemical composition and lithological characters of the various geological formations with chemical analyses, also remarks on the mode of occurrence of lead ore in northeastern Iowa. 
Whitney, J. D. County Geology. (Geol. Iowa, I, 259323. Albany, 1858.) Detailed notice of the geology of the central and northern counties in the eastern part of Iowa.

Whitney, J. D. Geological Map of the Lead Region in the States of Wisconsin, Illinois and Iowa. (Geol. Sur. Wisconsin, vol. I. . Albany, 1862.)

Whitney, J. D. Geology of the Lead Region. (Geol. Sur. Illinois, vol. I, pp. 153-207. Springfield, 1866.) Numerous references to the occurrence of lead in northeastern Iowa.

Whitney, J. D. Physical Geography of Iowa. (Geol. Iowa, vol. I, pp. 1-34. 1858.) A deseriptive account of the surface features, soil and climate of Iowa.

Williams, Albert, Jr. Mineral Resources of the United States. (U. S. Geol. Sur., Statistical Paper's for 1882, $813 \mathrm{pp}$. Washington, 1883.) Numerous references to Iowa mineral products.

Williams, Albert, Jr. Mineral Resources of the United States. (U. S. Geol. Sur., Statistical Papers for 188384, 1016 pp. Washington, 1885.) Numerous refererences to Iowa mineral products.

Williams, H.S. A Remarkable Fauna at the Base of - the Chemung in New York. (Am. Jour. Sei., (3), vol. XXV, pp. 97-104. New Haven, 1883.) A number of comparisons of fossils of the Lime creek beds of Iowa with those of New York.

Williams, H. S. Correlation Papers: Devonian and Carboniferous. (U. S. Geol. Sur., Bul. 80, pp. 1-279. Washington, 1891.) The rocks of Iowa discussed in a general way, and their correlation with other formations in the Mississippi valley noted. Numerous references. 
Williams, H. S. Equivalency of Lime Creek Beds. (Am. Jour. Sci., (3), vol. XXV, p. 311. New Haven, 1883.) A short note on the correction of statements made in a former publication.

Williams, H. S. On a Remarkable Fauna at the Base of the Chemung Group in New York. (Am. Jour. Sci., (3), vol. XXV, pp. 97-104. New Haven, 1883.) The Devonian fauna of Lime creek discussed and compared.

Williams, H. S. On the Relation of the Devonian Faunas of Iowa. (Am. Geologist, vol. III, pp. 230233. Minneapolis, 1888.) Remarks on the Devonian of Iowa.

Wilson, Park C. Biennial Report of the State Mine Inspector to the Governor of the State of Iowa, for the years 1880-1881. (Pamphlet, 1-165. Des Moines, 1882.) Brief accounts of the different mines in the state and incidentally reference to the geology.

Wilson, Park C. First Biennial Report of the State Mine Inspector for the years 1882-1883. (Pamphlet, 1-94. Des Moines, 1883.) Short accounts of coal mines throughout the state. There is also a number of records of borings made in various parts of Iowa.

Wilson, Park C. Second Biennial Report of the State Mine Inspector for the years 1884-1885. (Pamphlet, 1-116. Des Moines, 1885.) Short accounts of some of the mines of the state with list of all the mines and their location; also the records of several borings.

Winchell, Alexander. Description of Fossils from Yellow Sandstone lying below the Burlington Limestone at Burlington, Iowa. (Proc. Acad. Nat. Sci., Phila., $\mathrm{XV}$, pp. 2-25. Philadelphia, 1863.) A number of species and genera described as new. 
Winchell, Alexander. Description of New Species of Fossils from the Marshall Group of Michigan and its Supposed Equivalent in Other States: with Notes on Some Fossils of the Same Age Previously Described. (Proc. Acad. Nat. Sci., Phila., vol. XVII, pp. 109-133. Philadelphia, 1865.) Several species of fossils noted from Burlington.

Winchell, Alexander. The Marshall Group: A Memoir on its Geological Position, Characters and Equivalencies in the United States. (Proc. Am. Philosophical Soc., vol. XI, pp. 57-83. Philadelphia, 1869.) References to the correlation of the Kinderhook rocks of Iowa are given.

Winchell, N.H. Description of a Deep Well at Emmetsburg, Iowa. (Bul. Minnesota Acad. Sci., vol. I, pp. 387-390. Minneapolis, 1880.)

Winchell, N. H. Geology of Minnesota. (Geol. and Nat. Hist. Sur. Minnesota, Final Rep., vol. I, 697 pp. Minneapolis, 1884.) A number of incidental references given concerning the geology of Iowa.

\section{Winnebago County.}

Analysis of a Meteorite. J. Torrey and E. H. Barbour. (Am. Geologist, VIII, 67-72. 1891.)

Analyses of peat. Rush Emery. (Geol. Iowa, II, 398. 1870.)

General description. C. A. White. (Geol. Iowa, II, 247-249. 1870.) Brief general description of the surface characters.

Meteorites. Joseph Torrey, Jr., and E. H. Barbour. (Science, vol. XV, 347. 1890.) Reference to a fragment supposed to be a piece of meteorite. The authors claim it was not and base their claims on the grounds of: Too low specific gravity, absence of 
Winnnebago County.-Continued.

metals and external crust, and chemical analysis. Winnebago Meteorite. E. N. Eaton. (Am. Geologist, VIII, 385-387. 1891:)

\section{Winneshiek County.}

Notice of the geology. J. D. Whitney. (Geol. Iowa; I, 312-317. 1858.)

Witter, F. M. Gas Wells near Letts, Iowa (Am. Geologist, vol. IX, pp. 319-321. Minneapolis, 1892.) Notes on natural gas wells recently opened in Louisa county.

Witter, F. M. Notice of Arrow Points from the Loess in the City of Muscatine. (Proc. Iowa Acad. Sci., 18901891, pp. 66-68." Des Moines, 1892.) Announcement of arrow-heads found in brick pits in the loess at Muscatine.

Witter, F. M. ' Some Additional Observations on the Loess in and About Muscatine. (Proc. Iowa Acad. Sci., 1887-1889, p، 45. Des Moines, 1890.) Abstract of paper read before the Academy.

Witter, F. M. Some Geological Features near Muscatine. (Proc. Iowa'Acad. Sci., 1875-1880, p. 16. Iowa City, 1880.) Brief notice of the Loess and its fossils at Muscatine:

Witter, F. M. The Gas Wells near Letts, Iowa. (Proc. Iowa Acad. Sci.; 1890-1891; pp. 68-70 Des Moines, 1892.) Gas reported as being found in a number of places near Letts, in Louisa. county, and furnishing supplies for a number of families.

Wood.

In Iowa drift: C. A. White. (Geol. Iowạ, I, 97. 1870). Woodbury County.

Cretaceous deposits at the mouth of the Big. Sioux. 


\section{Woodbury County.-Continued.}

F. B. Meek. (U. S. Geol. Sur. Tẹ̣r., IX, p. xxv. 1876.)

Cretaceous rocks near Sioux City. J. Marcou. (Bul.

Soc. géol de France, (2), t. XXIV, 56. 1866.)

Description of the geology. O.H. St. John. (Geol. Iowa, II, 186-200. 1870.) The surface configuration noted. Stratigraphic geology described with a number of sections.

Relation of the Cretaceous Deposits of Iowa to the - Subdivisions of the Cretaceous proposed by Meek and Hayden. S..Calvin. (Proc. Iowa Acad. Sci, I, pt. iii, pp. 7-12. . 1893.)

\section{Worms.}

New species from the Devonian near Iowa City. S. Calvin. (Am. Geologist, I, 24-28. 1888.)

New. species from Paleozoic rocks of Iowa. C. A. White. (Proc. Acad. Nat. Sci., Phila., XXVIII, 27-34. 1877.)

\section{Worth County.}

Analyses of peat. Rush Emery. (Geol. Iowa, II, 398. 1870:).

Distribution of Rockford Shales, C. L. Webster. - (Proc. Davenport Acad. Nat. Sci., V, 100-109. 1887.)

General description. C. A. White (Geol. Iowa; II, 249-251. 1870.) A short account of the surface. characters.

Worthen, A. H. Description of Fossil Invertebrates. (Geol. Sur. Illinois, vol. VII, pp. 264-322. Springfield, 1883.) A number of species redescribed and figured from Iowa. 
Worthen, A. H. Description of Fossil Invertebrates. (Geol. Sur. Illinois, vol. VIII, pp. 69-154. Springfield, 1890.) A number of species described as new from Iowa.

Worthen, A. H. Description of New Species of Crinoids. (Illinois State Mus. Nat. Hist., Bul. No. 1, pp. 1-39. Springfield, 1882.) Several species from Iowa described as new.

Worthen, A. H. General Geology of Illinois. (Geol. Sur. Illinois, vol. I, pp. 1-153. Springfield, 1866.) Numerous references to the geology of eastern Iowa.

Worthen, A. H. Geology of Certain Counties. (Geol. Iowa, vol. I, pp. 132-258. Albany, 1858.) A detailed account of the geology of the following counties:

Lee county.

Des Moines county.

Henry county:

Van Buren county.

Jefferson county.

Washington county.

Wapello county.

Worthen, A. H. Geology of the Des Moines Valley. (Geol. Iowa, I, pp. 147-182, Albany, 1856.) A detailed geological account of a trip made up the Des Moines river during the year 1856, from Keokuk to Ft. Dodge, with numerous sections.

Worthen, A. H. Notice of a New Species of Platycrinus and Other Fossils from the Mountain Limestone of Illinois and Iowa. (Trans. Acad. Sci., St. Louis, vol. I, pp. 569-571. St. Louis, 1860.) Platycrinus pratteni described from Burlington, Iowa.

Worthen, A. H. On the Occurrence of Fish Remains in the Carboniferous Limestone of Illinois. (Proc. Am. 
Worthen, A. H.-Continued.

As. Ad. Sci., vol. X, pp. 189-192. 1856.) Beds containing fish remains recognized, the lower of which is near the top of the Burlington crinoidal limestone and has been recognized at Augusta, Iowa.

Worthen, A. H., F. B. Meek and. Contribution to the Paleontology of Illinois and other Western States. (Proc. Acad. Nat. Sci., Phila., vol. XIX, pp. 251-275. Philadelphia, 1868.) See F. B. Meek and A. H. Worthen, 1868.

Worthen, A. H., F. B. Meek and. Description of New Carboniferous Fossils from Illinois and Other Western States. (Proc. Acad. Nat. Sci., Phila., vol. XII, pp. 447-472. Philadelphia, 1860.) See F. B. Meek and A. H. Worthen, 1860.

Wothen, A. H., F. B. Meek and. Description of New Crinoidea and Echinoidea from the Carboniferous Rocks of the Western States; with a note on the Genus Onychaster. (Proc. Acad. Nat. Sci., Phila., vol. XXI, pp. 67-83. Philadelphia, 1869.) See F. B. Meek and A. H. Worthen, 1869.

Worthen, A. H., F. B. Meek and." Description of New Paleozoic Fossils from Illinois and Towa. (Proc. Acad. Nat. Sci., Phila., vol. XIII, pp. 128-148. Philadelphia, 1861.) See F. B. Meek and A. H. Worthen, 1861.

Worthen, A. H., F. B. Meek and. Description of New Species of Crinoidea, etc., from the Paleozoic Rocks of Illinois and Some of the Adjoining States. (Proc. Acad. Nat. Sci., Phila., vol. XVII, pp. 143-156. Philadelphia, 1865.) See F. B. Meek and A. H. Worthen, 1865. 
Worthen, A. H., F. B. Meek and. Description of New - Species and Genera of Fossils from the Paleozoic Rocks of the Western States. (Proc. Acad. Nat. Sci., Phila., vol. XIII; pp. 22-56. Philadelphia, 1870.) See F. B. Meek and A. H. Worthen; 1870.

Worthen; A. H., F. B. Meek and. Descriptions of New Species of Crinoidea and Echinoidea from the Carboniferous Rocks of Illinois and Western . States. (Proc. Acad. Nat. Sci.; Phila., vol. XII, pp. 378-397. Philadelphia, 1860.) See F. B. Meek and A. H. Worthen, 1860.

Worthen, A. H., F. B. Meek and. Description of Invertebrates. (Geol. Sur. Illinois, vol. VI, pp. 489-532, with plates. Springfield; 1875.) A number of species from Iowa rocks noted.

Worthen, A. H., F. B. Meek and. Description of New Invertebrates from the Carboniferous System. (Geol. Sur. Illinois, vol. II, pp. 143-411. Springfield, 1866.) See F. B. Meek and A. H. Worthen, 1866.

Worthen, A. H., F. B. Meek and: Description of Invertebrates from the Carboniferous System. (Geol. Sur. Illinois, vol. V, pp. 323-619, with plates. Springfield, 1873.) See F. B. Meek and A. H. Worthen, 1873.

Worthen, A. H., F. B. Meek and. Notes on Some Points in the Structure and Habits of Paleozoic Crinoidea. (Proc. Acad. Nat. Sci., Phila., vol. XX, pp. 323-334. Philadelphia, 1868.) See F. B. Meek and A. H. Worthen, 1868.

Worthen, A. H., F. B. Meek and. Paleontology of Illinois. (Geol. Sur. Illinois, vol. III, pp. 289-565, with plates. Springfield, 1868.) See F. B. Meek and A.H. Worthen, 1868. 
Worthen, A. H., F. B. Meek and. Remarks on the Age of the Goniatite Limestone at Rockford, Indiana, - and its Relations to the Black Slate of the Western States and to some of the Succeeding Rocks of the Latter. (Am. Jour. Sei., (2), XXXII, 167-177. 1861.)

Worthen, A. H., .F. B. Meek and. Remarks on the Blastoidea, with Descriptions of New Speeies. (Proc. Acad. Nat. Sci., Phila., vol. XXI, pp. 83-91. Philadelphia, 1869.) See F. B. Meek and A. H. Worthen, 1869.

Worthen, A. H., F. B. Meek and. Remarks on the Genus Taxocrinus (Phillips) MeCoy, 1844; and its Relations to Forbesiocrinus, Koninck and Le Hon, 1854 ; with Description of New Species. (Proc. Acad. Nat: Sci., Phila., vol. XVII, pp. 138-143. Philadelphia, 1865.) See.F. B. Meek and A. H. Worthen, 1865.

Worthen, A. H., F. B. Meek and. Remarks on Some Types of Carboniferous Crinoidea, with Descriptions of New Genera and Species, of the Same, and of one Echinoid. (Proc. Acad. Nat. Sci., Phila., vol. XX, pp. 335-359. Philadelphia, 1868.). See F. B. Meek and A. H. Worthen, 1868.

Worthen, A. H., J. S. Newberry and. Deseription of New Species of Vertebrates. (Geol. Sur. Illinois, vol. II, pp. 9-134, with plates. Springfield, 1886.) See J. S. Newberry and A. H. Worthen, 1866.

Worthen, A. H., J. S. Newberry and. Description of Vertebrates. (Geol. Sur. Illinois, vol. IV, pp. 346374, with plates. Springfield, 1870.) See J. S. Newberry and A. H. Worthen, 1870.

Worthen, A. H., O. H. St. John and. Description of Fossil Fishẹs. (Geol. Sur. Illinois, vol. VI, pp. 245- 
Worthen, A. H., etc.-Continued.

288, with plates. . Springfield, 1875.) See O. H. St. John and A. H. Worthen, 1875.

Worthen, A. H., O. H. St. John and. Description of Fossil Fishes. (Geol. Sur. Illinois, vol. VII, pp. 53264. 1883.) See O. H. St. John and A. H. Worthen, 1883.

Wright County.

Analyses of peat. Rush Emery. (Geol. Iowa, II, 399. 1870.)

General description. C. A. White. (Geol. Iowa, II, 241-243. 1870.) A brief general account of the surface features.

Zinc.

Ore deposits of southwestern Wisconsin. T. C. Chamberlin. (Geol. Sur. Wisconsin, IV, 367-568. 1882.)

In Iowa. J. D. Whitney. (Geol. Iowa, I, 469-471. 1858.)

Its occurrence in Iowa. C. A. White. (Geol. Iowa, II, 241-242. 1870.) The ores of this metal reported from Dubuque.

Zittel, Karl A. Handbuch der Palæontologie. (I Band, pp. 1-765. München, 1880.) Illustrations of a number of fosșils from Iowa. 